National Stereotyping, Identity Politics, European Crises 


\section{Studia Imagologica}

AMSTERDAM STUDIES ON CULTURAL IDENTITY

Series Editors

Hugo Dyserinck ${ }^{\dagger}$

Joep Leerssen (University of Amsterdam)

VOLUME 27

The titles published in this series are listed at brill.com/imag 


\title{
National Stereotyping, Identity Politics, European Crises
}

\author{
Edited by
}

Jürgen Barkhoff and Joep Leerssen

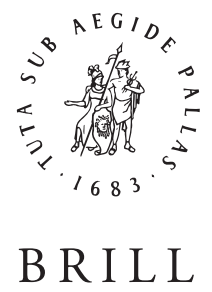

LEIDEN | BOSTON 
This is an open access title distributed under the terms of the CC BY-NC-ND 4.0 license, which permits any non-commercial use, distribution, and reproduction in any medium, provided no alterations are made and the original author(s) and source are credited. Further information and the complete license text can be found at https://creativecommons.org/licenses/by-nc-nd/4.0/

The terms of the Cc license apply only to the original material. The use of material from other sources (indicated by a reference) such as diagrams, illustrations, photos and text samples may require further permission from the respective copyright holder.

Cover illustration: @ The Board of Trinity College Dublin.

Library of Congress Cataloging-in-Publication Data

Names: Barkhoff, Jürgen, edi | Leerssen, Joseph Th. (Joseph Theodoor), 1955-edi

Title: National Stereotyping, Identity Politics, European Crises / Edited by Jürgen Barkhoff and Joep

Leerssen.

Description: Leiden ; Boston : Brill 2021. | Series: Studia imagologica,

o927-4065; Volume 27 | Includes index.

Identifiers: LCCN 2021012846 (print) | LCCN 202101 (ebook) | ISBN

9789004434554 (hardback) | ISBN 9789004436107 (ebook)

Subjects:

Classification: LCC HMiog6 .N37 2021 (print) | LCC HMiog6 (ebook) | DDC

$303.3 / 85094-\mathrm{dc} 23$

LC record available at https://lccn.loc.gov/2021012846

LC ebook record available at https://lccn.loc.gov/2021012847

Typeface for the Latin, Greek, and Cyrillic scripts: "Brill". See and download: brill.com/brill-typeface.

ISSN 0927-4065

ISBN 978-90-04-43455-4 (hardback)

ISBN 978-90-04-43610-7 (e-book)

Copyright 2021 by Jürgen Barkhoff and Joep Leerssen. Published by Koninklijke Brill NV, Leiden, The Netherlands.

Koninklijke Brill Nv incorporates the imprints Brill, Brill Hes \& De Graaf, Brill Nijhoff, Brill Rodopi, Brill Sense, Hotei Publishing, mentis Verlag, Verlag Ferdinand Schöningh and Wilhelm Fink Verlag. Koninklijke Brill NV reserves the right to protect this publication against unauthorized use.

This book is printed on acid-free paper and produced in a sustainable manner. 


\section{Contents}

Notes on Contributors IX

List of Figures and Tables XIV

Introduction 1

Jürgen Barkhoff and Joep Leerssen

\section{PART 1 \\ History and Identity Politics}

1 Confronting the Other/Perceiving the Self

National Historiographies and National Stereotypes in Twentieth-Century

Europe 15

Stefan Berger

2 Claiming a Great Ancient Imperial Past as an Identity Element of a Small Modern Nation

The Case of Lithuania 31

Zenonas Norkus and Aelita Ambrulevičiūtè

3 The Longue durée of Brexit

Politics, Literature and the British Past $\quad 5^{1}$

Daniel Carey

\section{PART 2}

\section{Identity Politics of the Neo-Right}

4 From Identity Politics to the Identitarian Movement

The Europeanisation of Cultural Stereotypes? 75

Karel Šima

$5 \mathrm{Re} /$ nationalising EU-rope

National Identities, Right-Wing Populism, and Border- and

Body-Politics 95

Ruth Wodak 


\section{PART 3}

Strategies of Othering

6 The Camp and the Home

Europe as Myth and Metaphor 125

Joep Leerssen

7 The EU and the East-West Paradox

The Case of Greece and Turkey 142

Hercules Millas

8 The Image of the Wall

The Antemurale Christianitatis Myth from an Imagological

Perspective 160

Zrinka Blažević

\section{PART 4}

Stereotyping in the Media

$9 \quad$ Prime Time Nationalism

Patterns of Prejudice in TV Crime Fiction 175

Wulf Kansteiner

10 Stereotyping by Default in Media Transfer 205

Luc van Doorslaer

11 The Image of Spain in the Eyes of Austrian, Flemish, French, Italian, Polish and Bulgarian Facebook Users

Text-Linguistic Opinion-Mining for Detecting and Analysing National

Stereotypes 221

Raúl Sánchez Prieto

\section{PART 5}

The Economic Crisis in Literature

12 Resilient Stereotypes in Recent Crisis Novels from Spain 247 Ana María Fraile 
13 Virtually There

Spectral Ireland and European Stereotypes in the Novels of Paul Murray $\quad 267$ Aidan O'Malley

Index of Names 285 


\section{Notes on Contributors}

Aelita Ambrulevičiūtè

(PhD 2010) is Senior Research Fellow at the Institute of Sociology and Social Work, Faculty of Philosophy, Vilnius University. Her research area is economic and social change in Lithuania in the nineteenth and twentieth centuries, with special interest in urban history. Recent book (co-authored with Ginte Konstantinavičiūtė and Giedrè Polkaitė-Petkevičienè): Houses that Talk. Sketches of Everyday Life in Vokiečiu Street in 19th-2oth centuries (in Lithuanian, 2018).

\section{Jürgen Barkhoff}

is Professor of German (1776) at the Department of Germanic Studies in the School of Languages, Literatures and Cultural Studies at Trinity College Dublin, University of Dublin. He teaches German literature and German and European cultural history from 1750 to the present. His main research areas are literature and medicine, science and psychology around 180o, questions of identity in the German speaking world and contemporary Swiss literature. He is also the Vice-Provost, Chief Academic Officer and Deputy-President of Trinity College and Vice-Chair of the Executive Board of the Coimbra Group of European Universities. From 2013 to 2018 he led the university-wide, interdisciplinary research theme 'Identities in Transformation'.

\section{Stefan Berger}

is Professor of Social History and Director of the Institute for Social Movements at the Ruhr-Universität Bochum. He is also Executive Chair of the Foundation History of the Ruhr and an Honorary Professor at Cardiff University. He has published widely in the fields of comparative labour history, the comparative history of regions of heavy industry, industrial heritage, memory history, the history of historiography and historical theory, as well as on British-German relations and the history of national identity and nationalism. His most recent monograph is The Past as History. National Identity and Historical Consciousness in Modern Europe (Palgrave MacMillan, 2015).

\section{Zrinka Blažević}

is Full Professor at the History Department, Faculty of Humanities and Social Sciences, University of Zagreb (Croatia). She has published four books: Pavao Ritter Vitezović, Croatia rediviva/ Croatia Revived (1998); Vitezovićeva Hrvatska između stvarnosti i utopije/ Vitezovićs Croatia Between Reality and 
Utopia (2003); Ilirizam prije ilirizma/Illyrism before Illyrism (2008); Prevođenje povijesti/Translating History (2014), and numerous papers and articles on early modern Croatian history. Her main fields of interest are intellectual history, critical discourse analysis, theory of history and historical imagology.

\section{Daniel Carey}

the Director of the Moore Institute for Research in the Humanities and Social Studies at the National University of Ireland Galway, is a graduate of McGill University, Trinity College Dublin, and Oxford University, where he took his DPhil. His book on Locke, Shaftesbury, and Hutcheson. Contesting Diversity in the Enlightenment and Beyond appeared with Cambridge University Press in 2006. He has published edited volumes on Renaissance travel, Richard Hakluyt, Jonathan Swift, money and political economy in the eighteenth century, and the postcolonial enlightenment.

\section{Luc van Doorslaer}

is Chair Professor of Translation Studies at the University of Tartu (Estonia). Previously he was the director of CETRA, the Centre for Translation Studies at KU Leuven (Belgium). As a Professor Extraordinary he is affiliated with Stellenbosch University (South Africa). Since 2016 he has been Vice President of the EST, the European Society for Translation Studies. Together with Yves Gambier, he is the editor of the online Translation Studies Bibliography (2004-ongoing) and the four volumes of the Handbook of Translation Studies (2010-13). Other recentbooks edited includeEurocentrism in Translation Studies (2013), The Known Unknowns of Translation Studies (2014), Interconnecting Translation Studies and Imagology (2016), Border Crossings. Translation Studies and other Disciplines (2016) and The Situatedness of Translation Studies (2021). His main research interests are journalism and translation, ideology and translation, imagology and translation, institutionalisation of Translation Studies.

\section{Ana María Fraile-Marcos}

is Associate Professor of English at the University of Salamanca, Spain, where she teaches English, Canadian and Postcolonial Literatures. At present, she is the Head of the English Department and the Director of the Master in Creative Writing. Her major publications include Glocal Narratives of Resilience, ed. (Routledge, 2020); Literature and the Glocal City. Reshaping the English Canadian Imaginary, ed. (Routledge, 2014); Richard Wright's 'Native Son, ed. (2007); Planteamientos estéticos y políticos en la obra de Zora Neale Hurston (2003), and numerous chapters and articles in peer-reviewed journals. She coordinates the research project Narratives of Resilience. An Intersectional 
Approach to Literature and Other Contemporary Cultural Representations and is a member of the project Transcanadian Research Networks.

\section{Wulf Kansteiner}

is Professor of History in the School of Culture and Society at the University of Aarhus in Denmark. He is a cultural historian focused primarily on memory, media history, twentieth century Europe, and on representations of the Second World War and the Holocaust in Germany. He has published widely on these topics and is additionally co-editor and co-founder of the Sage Journal of Memory Studies.

\section{Joep Leerssen}

holds the chair of Modern European Literature in the Department of European Studies, University of Amsterdam. He is one of the world's leading experts in imagology and has published widely on the link between national (self-)images and nationalism; articles on these topics have appeared in Poetics Today, Nations and Nationalism, and the Journal of the British Academy. Among his book publications are the Handbook Imagology (co-edited with Manfred Beller, 2007), National Thought in Europe (3rd edn 2018), and the Encyclopedia of Romantic Nationalism in Europe (2 vols; one of the TLS books of the year for 2018). He is recipient of the Mme de Staël Prize 2020 from ALlEA, the consortium of European Academies, for his contribution to the cultural values of Europe.

\section{Hercules (Iraklis) Millas}

was brought up in Turkey and presently lives in Greece. He is an independent author. He has a Ph.D. degree in political science and a B.Sc. in civil engineering. During the period 1990-1995 he contributed to establishing the Greek department at Ankara University and from 1999 to 2008 he taught Turkish literature and Turkish political thought in various Greek Universities.

\section{Zenonas Norkus}

(PhD 1984, Habilitation 2002) is Professor at the Institute of Sociology and Social Work, Faculty of Philosophy, Vilnius University. His book publications include Max Weber und Rational Choice (in German, 2001); Which Democracy, Which Capitalism? Post-communist Transformation in Lithuania from the Viewpoint of Comparative Historical Sociology (2008); An Unproclaimed Empire. Grand Duchy of Lithuania from the Viewpoint of Comparative Historical Sociology (2009); On Baltic Slovenia and Adriatic Lithuania. A Qualitative Comparative Analysis of Patterns in Post-Communist Transformation (in English, 2012), Two Twenty-Year Periods of Independence. Capitalism, Class and Democracy from the Point of View of Comparative Historical Sociology (2014). 


\section{Aidan O'Malley}

received his $\mathrm{PhD}$ from the European University Institute and teaches at the University of Rijeka. He is the author of Field Day and the Translation of Irish Identities. Performing Contradictions (Palgrave Macmillan, 2011), and has edited Ireland, West to East, Irish Cultural Connections with Central and Eastern Europe (with Eve Patten, Peter Lang, 2014), and a special issue of the European Journal of English Studies 17:2 (August 2013) on 'Myths of Europe. East of Venice'. He has also published other articles and chapters that take translational and transnational perspectives on Irish literature and culture.

\section{Raúl Sánchez Prieto}

is Professor of German at the Department of Modern Philology of the University of Salamanca, where he teaches German linguistics. His main research interests focus on German-Spanish contrastive linguistics, particularly contrastive media discourse analysis, and language conflict. He has been the principal investigator in several research projects related to computermediated communication.

\section{Karel Šima}

is Assistant Professor at the Institute of Economic and Social History, Faculty of Arts, Charles University in Prague. He earned his $\mathrm{PhD}$ from Charles University in history and anthropology with a thesis on Czech national festive culture in the nineteenth century. His research interests include cultural nationalism and the role of performance within national movements, but also subcultures and Do-It-Yourself activism, history of concepts and narrativism in historiography. He has published journal articles on national festive culture, nationalist choral societies, relations between history and anthropology, and co-authored books on the Humboldtian model of universities and ethnography of higher education departments.

\section{Ruth Wodak}

is Emerita Distinguished Professor of Discourse Studies at Lancaster University, UK and affiliated to the University of Vienna. Besides many other prizes, she was awarded the Wittgenstein Prize for Elite Researchers in 1996. 2008, she was awarded the Kerstin Hesselgren Chair of the Swedish Parliament and an Honorary Doctorate from the University of Örebro in Sweden in 2010 and an Honorary Doctorate at Warwick University in 2020. In 2011, she was awarded the Grand Decoration in Silver for Services for the Austrian Republic, in 2018 the Life-Achievement Prize of the Austrian Ministry of Women. She is a member of the British Academy of Social Sciences and the Academia Europea, 
and an Honorary Member of the Senate of the University of Vienna. Recent book publications include Europe at the Crossroads (with P. Bevelander, 2019); The Routledge Handbook of Language and Politics (with B. Forchtner, 2018); The Politics of Fear (2015, second revised and extended edn 2020); The discourse of politics in action. 'Politics as Usual', 2nd revised edn (Palgrave, 2011); Migration, Identity and Belonging (with G. Delanty, P. Jones, 2011); The Discursive Construction of History. Remembering the Wehrmacht's War of Annihilation (with H. Heer, W. Manoschek, A. Pollak, 2008) and The Politics of Exclusion (with M. Krzyżanowski, 2009). 


\section{Figures and Tables}

\section{Figures}

1.1 Statue of Garibaldi on the Gianicolo hill in Rome Source: Photograph by Stefan Berger 16

5.1 The normalisation of extreme-right ideology 106

5.2 Vilimsky (Party Secretary), Strache, Gudenus and Kickl (Party Secretary) brandishing the Austrian flag at the Großglockner peak (Austria's highest mountain). Source: From HC Strache's personal Facebook page 'HC Strache', 27.08.2015 at www.facebook.com/HCStrache [accessed 01.07.2017] 114

5.3 Still from the FPÖ's alternative anthem and election campaign video. Source: F PÖ, 'Immer wieder Österreich', o8.04.2016 available on the F Pö YouTube Channel at www.youtube. com/watch?v=IcV6aUw4xhU [accessed 01.07.2017] 115

10.1 The front page of the Daily Mirror, 24 June 1996 Source: Daily Mirror, 24 June 1996213

10.2 German Chancellor Angela Merkel presented as Hitler in the Turkish newspaper Güneş. Source: Güneş, 10 March 2007215

10.3 Central Europe by political as well as cultural criteria. Source: https:// en.wikipedia.org/wiki/Central_Europe\#/media/File:CentralEurope2.PNG [accessed 30.08.2018] 216

\section{Tables}

5.1 Four-level Context-Model 104

11.1 Corpus description 228

11.2 Secondary text actions (STAs) assessing Spain in Northern, Southern and Eastern European comments 229

11.3 STAs and PSTAs assessing Spanish society in Northern, Southern and Eastern European comments about Spain 230

11.4 STAS and PSTAs assessing the Spanish economy in Northern, Southern and Eastern European comments about Spain 233

11.5 STA sand PSTAs assessing Spanish politics in Northern, Southern and Eastern European comments about Spain $\quad 236$

11.6 STAS and PSTAs assessing the Spanish on other topics in Northern, Southern and Eastern European comments about Spain $\quad 238$

11.7 Collocation candidates (terms) by co-occurrence count: Spain 239

11.8 Top 1o key words (terms) of the subcorpora in Spain-related contexts 240 


\title{
Introduction
}

\author{
Jürgen Barkhoff and Joep Leerssen
}

National Stereotyping - Identity Politics - European Crises. As its title indicates, the papers in this volume seek to address and analyse long-term cultural and historic discourses on identity and othering in Europe in their impact on recent European politics. This link between discursive traditions and current affairs has not received much scholarly or political attention, although it became highly influential in the experience of the post-2008 European crises, many of which are either ongoing or at least latent, ready to be reactivated at any time. The contributions to this volume examine how such crisis discourses were in many ways informed and structured by recourse to historically influential, deeply ingrained patterns of national and transnational ethnotyping and othering. Mostly in the service of an antagonistic identity politics of us versus them and demarcation and exclusion, politicians and opinion makers across Europe have revived, reactivated, and instrumentalised divisive auto- and hetero-images of European nations and people, as well as narratives of cultural conflict that go back many centuries. This longue durée of established auto- and heteroimages, of divisive narratives and patterns of interpretation as well as their actualisation and application in contemporary politics could be observed in many fields.

During the financial crisis since 2008 the bailout politics of the European Union and the International Monetary Fund for countries such as Greece, Portugal, Spain and Ireland were regularly interpreted as the imposition of a protestant work and frugality ethic by Northern countries, led by a pastor's daughter from the Prussian hinterland, on an undisciplined, self-indulgent or even lazy Catholic South.

In a similar line, the Ukraine conflict since 2013 has habitually been depicted in terms of a clash between Western forces of civilisation informed by Enlightenment values and represented by the EU, and a non-civic East, naturally drawn to despotism and violence, represented by Russia, with the Ukraine in the middle.

The rise of authoritarian leadership and illiberal democracies in countries such as Hungary, Poland, Russia or Turkey was underpinned and fostered by a neo-nationalist identity politics that re-mobilised nativist sentiment with crude ethnotypes and nationalistic interpretations of the past. Such essentialising models of identity are supported by a rhetoric which argues the uniqueness, if not superiority of one's own nation, its cultural model and traditional value system and calls for its defence against threatening and dangerous

(C) JÜRGEN BARKHOFF AND JOEP LEERSSEN, 2021 | DOI:10.1163/9789004436107_002

This is an open access chapter distributed under the terms of the CC BY-NC-ND 4.0 license. 
outside influences such as liberalism, transnationalism, migration or other forces of globalisation.

Similarly, the neo-nationalist, euro-sceptic and xenophobic populist movements and parties which have been on the rise across Europe draw heavily on essentialising cultural identities and antagonistic ethnotypes.

In particular the rhetoric and politics of Brexit, which came to dominate European politics since the referendum in 2016, was fuelled by a nostalgic nationalist interpretation of past glory, exceptionalism and isolationist unilateralism.

Equally, the temporary opening of the European borders in 2015 with its substantial influx of refugees and migrants, the ensuing crisis and the subsequent problems of integration have been discursively framed predominantly as a loss of control and sovereignty and structured by crude juxtapositions of Self versus Other, a dynamics of inclusion and exclusion and projective mechanisms of scapegoating and fear mongering.

It is the contention of this book that the discursive processes at work here follow fixed patterns, have a great deal in common and need to be better understood. The underlying patterns and master narratives have a long history and draw on culturally constructed, but highly influential historical myths, cultural memories and identities, stereotypes of national characteristics, self-, hetero- and meta-images and processes of othering. Stereotyping and othering are enormously powerful, as they are anthropologically deeply rooted cognitive and affective practices necessary to make sense of the world by reducing complexities, providing orientation and creating a sense of familiarity. Their connection with history and identity and the way in which they connect collective and personal memory make them emotionally visceral, enable them to mobilise deep affects, link individual and collective experience and forge strong identifications. As a result they are both pervasive and influential, and paradoxically their very pervasiveness makes them appear 'banal' (in Michael Billig's sense of the word), ${ }^{1}$ ambient, thus hiding their political potency in plain sight. Hence the need to analyse their presence, their historical roots, their representational power and their discursive logic.

This volume presents the papers delivered by distinguished specialists from a variety of relevant disciplines and from all over Europe at a conference held in March 2017 at the Trinity Long Room Hub (the Arts \& Humanities Research Institute of Trinity College Dublin). Its contributions investigate these crucial cultural and historical dimensions behind recent European crises. They interrogate the uses and abuses of stereotypes and narratives of othering in crisis discourse from fields as varied as history, historiography, cultural history,

1 See Billig (1995). 
sociology, ethnology, imagology, stereotyping research, memory studies, media studies, identity studies, translation studies and literary analysis.

The two most relevant and important methodologies applied in this volume are those of Imagology and Critical Discourse Analysis. They are represented by two of their leading theoreticians and champions, Joep Leerssen and Ruth Wodak respectively, but also employed by many other contributors.

Imagology as a method of analysing discourses of national character and patterns of prejudice and stereotyping developed in the 1950s and 196os within Comparative Literature, mainly in France, the Netherlands, Austria and Germany; its emergence ran in tandem with Europe's post-war reconciliation project. By looking at representations of national character as prejudices, tropes and myths, it opened up their genesis, mechanisms, history and influences to analysis, offering a critical alternative to that national essentialism and ethnotyping, which had dominated the age of nationalism and of the two World Wars. Thus it was and still is a form of applied cultural studies in the service of the European peace project. From its literary beginings, it has broadened out to the methods and theories of social psychology, prejudice research, media studies, mentality history, cultural memory studies and critical discourse analysis.

Focussing on the historical genesis and discursive structures and functions of auto- and heteroimages for identity discourses, imagology avoids an essentialist reading of its results by carefully triangulating the dimensions of text, context and intertext: the rhetorical and narrative function of ethnotypes within the text; the historical-contextual analysis of the text's production and reception history as situated in the ideological field and in the international relations of the given moment; and the provenance of the ethnotyes as tropes in their intertextual transmission, their constants and variables as discursive formulae. At each stage the internal logic and a priori assumptions of ethnotypes are critically deconstructed: the assumption of the nation's homogeneity across regional, gender, age-group and class differentiations; the assumption of its fundamental differentness from other (equally homogenised) nations; the assumption of its invariant characterological permanence over time. Whereas the working corpus of imagology was originally limited to literary representations, other modes of cultural production and reproduction are now included, notably narrative in film and audiovisual media, journalism, political discourse, tourism, design and museum displays. ${ }^{2}$

2 See Leerssen (2000); Beller, Leerssen (2007); Leerssen (2016). 
A number of general imagological insights into the dynamic of auto- and hetero-images are of particular relevance for this volume. The first is that the discourses of national character and ethnotyping are intrinsically geared towards exceptionalism, as they tend to emphasize difference and play down or overlook similarities, even though those are generally much more common. Leerssen calls the underlying fallacy of this discursive pattern "the a-priori denial of normalcy: the assumption that a nation is most characteristically itself in precisely those aspects in which it is most different from others." ${ }^{3}$ The second point is that the oppositional cultural and temperamental matrix between people or social groups is applied in stereotypical and invariant oppositions such as the one between a cool, cerebral north and a hot, passionate south, between a civically-minded west and a despotic east, between a dynamically developing, societal centre and a tradition-bound, communitarian periphery. Such oppositions are geographically unspecific, and can be applied across and between continents, countries or regions as the case happens to fit a chosen frame and perspective. A given society or social group can be represented and temperamentally characterised, contingently, as western or eastern, as northern or southern, as central or peripheral, depending on the point of view. Other generic rhetorical markers that can be deployed to manipulate readers' estimations of foreign characters are in the selective, opportunistic distribution of general human virtues such as familiality, honesty, hospitality, courage in adversity, and a work-ethic reliability. Attributing such virtues to members of any nation will serve to render the nation (thus represented by its virtuous members) more sympathetic; and since the distribution of such moral markers is a central element in the narrative, actantial configuration of role patterns, it determines the narrative configuration of national characterisations. The underlying logic is that an individual of an exotic nationality is always perceived as representative of that nationality as a whole.

A final general insight is the pattern that that the valorisation of temperaments is strongly dependent on external political factors. Tensions and crises in international relations tend to trigger a surge in antagonistic national stereotyping, while during calmer and more stable political times shared values and attitudes are being foregrounded and temperamental differences are viewed in a more benign light. In many ways this last observation provides the rationale for this volume. Imagology as a method developed out of a desire to overcome the catastrophic legacies of European nationalism and fascism: it is of renewed relevance today at this historical juncture where neo-nationalisms and neo-right movements are gaining fresh virulence.

3 Leerssen (2016), p. 17. 
Critical Discourse Anaylsis (CDA) has proven to be equally important for the topics discussed in this book, as it approaches language as a social practice and focusses on the way power is mediated, enacted, reproduced or challenged through language and text. Rooted in the linguistic turn and Critical Theory and combining detailed and qualitative linguistic analysis of a wide array of text types and communicative situations and media with sociological and political macro-theories of societies, CDA offers a set of theoretical and analytical tools for the interdisciplinary interrogation of the relationship between textual and communicative discursive practices and social formations. CDA has a distinct engaged or even activist dimension, as its critical aim is to make hidden power structures and their underlying ideological assumptions and prepositions visible and in this way raise awareness about discursive power relations. ${ }^{4}$ Over the last 25 years the study of stereotyping, prejudice and discrimination in ethnocentric, nationalist and racist discourse has become an increasingly important field within Critical Discourse Analysis. Ruth Wodak and her research group in particular have turned their attention to political rhetoric especially of neo-nationalism and new movements on the extreme right, anti semitism, xenophobia, identity politics and narratives of the past, the very issues taken up by this volume. ${ }^{5}$ For its analysis she and her collaborators have developed a specific approach within CDA, the Discourse-Historical Approach DHA, which integrates elements of historiography, political science and sociology. ${ }^{6}$ Of equal importance for a number of contributions in this volume is the fact that Critical Discourse Analysis in recent years widened its scope to include a number of media and discursive fields that have an increasing influence on public opinion and political positions around the issues at stake in this volume such as journalism, reality television, television more general, film and also new social media. ${ }^{7}$

The contributions of this volume divide into five parts. Part 1 investigates how national histories and historiographies contributed to the identity politics of European countries and served their political objectives; Part 2 analyses the discursive and performative practices of the neo-nationalist and populist right; Part 3 discusses strategies of othering and of exclusion/inclusion between East

4 See for example van Dijk (2001); Flowerdew, Richardson (2017).

5 See for example Wodak (2017).

6 On DHA see Reisigl, Wodak (2009); Reisigl (2017).

7 See section 5 of Flowerdew, Richardson (2017). 
and West; Part 4 examines the role of media such as journalism, prime time $\mathrm{TV}$ and social media in disseminating, reinforcing and also countering stereotypes; Part 5 describes how literary fiction critiques and counteracts processes of stereotyping and othering that have become prevalent during the economic crisis.

In Part 1 'Historiography and Identity Politics' Stefan Berger examines the complex relationship between national historiographies and processes of national stereotyping. Drawing on a pan-European comparative project on national historiographies under his coordination, Berger presents five case studies from across Europe, which demonstrate how academic history-writing in the 2oth century frequently relied on binary stereotypes (positive national auto-images and negative hetero-imagines). Professional historiography often legitimised self-serving politics by providing academic credentials to ingrained prejudices. This tendency outweighs attempts by academic historiography to critique or counteract such stereotypes. Berger looks at how British and German historians fed into hate propaganda during World War I, how German Inter-war Volksgeschichte helped prepare the ground for racist expansionism during the Nazi-period, how the re-writing of national histories across Europe was instrumentalised for Cold War ideologies, and how Eastern European master narratives were re-nationalised after the fall of Communism.

Zenonas Norkus and Aelita Ambrulevičiüté pick up the topic of the influence of national historiography on recent foreign policy by presenting a case study on the link between Lithuanian national history and its political positions around the Ukraine crisis. They analyse how Lithuania's very proactive stance on an Eastern expansion of EU and NATO, which contributed to the tensions in the region, was underpinned, legitimised and strengthened by recourse to its late-medieval and early-modern imperial past, when the Grand Duchy of Lithuania was the dominant regional power in Eastern Europe. They demonstrate how these identity narratives and memory discourses were carried by influential political figures in the re-established Republic of Lithuania, driving the country's foreign policy with this vision of once and future grandeur as a predominant broker and promoter of democracy and Western values. That position revived old East-West antagonisms and not only antagonised Russia, but also annoyed other neighbouring states, especially Poland.

Daniel Carey traces and illustrates some historical aspects of British exceptionalism, which proved to be such a powerful force in the Brexit referendum and its aftermath. He discusses the sixteenth century English Reformation as the seedbed of continuing attitudes, leading to the anti-EU agenda to 'take back control' and assert sovereignty against foreign influences. Literary sources to complicate and counteract the exceptionalist narrative start with Daniel 
Defoe's The True-Born Englishman (1701), which already contests notions of national character by pointing to the enriching and heterogeneous influences of various invaders, refugees and migrants. Carey also detects related arguments for hybridity in Robinson Crusoe and goes on to demonstrate that already in the Renaissance a number of Shakespeare plays such as Richard II and Henry $v$ similarly complicate and contest nationalist narratives. Carey's reading argues that such historical and literary perspectives offer insight both into the forces that drive Brexit as well as the simplifications and fallacies that drive the debate.

In Part 2 'Identity Politics of the Neo-Right' Karel Šima's contribution offers a wide-ranging overview of the identitarian movement across Europe, its political aims, underlying ideologies and forms of political activism since 2012. He analyses how the movement has, to great effect, copied the activist protest forms and identity politics of leftist social movements, appropriating them for their far-right political agenda. The movement successfully employs social media and political performance to appeal to a young generation and to maximise its visibility. Sima's analysis demonstrates how the identitarian movement has embraced the concepts of metapolitics and cultural hegemony, borrowed from Gramsci, and sees culture and collective memory as their main battleground. He shows how the movement has simultaneously adapted cultural references both from pop culture and mainstream European conservatism, folk culture and 'banal nationalism' to appear youthful and energetic while at the same time projecting an image as conservative defenders of European values and traditions against the threatening forces of globalisation and liberalism.

Ruth Wodak analyses the discursive strategies of Austria's extreme-right Freedom Party, the FPÖ, as a characteristic example of similar tendencies among other neo-nationalist, populist and xenophobic parties in Europe. She highlights in particular the construction and propagation of a highly normative and exclusivist nativist notion of nation and people, which is portrayed as constantly besieged, not only externally by migrants and transnational institutions such as the EU, but also internally by increasing diversity and gender politics. Her analysis shows how the FPÖ's confrontational campaign style, partly by means of social media, uses continuous provocation and scandalisation with the aim to normalise and mainstream its radical positions. These tactics proved particularly successful during the short-lived coalition between the FPÖ and the Austrian Peoples Party, the övP under Chancellor Kurz from December 2017 to May 2019.

In Part 3 'Strategies of Othering' Hercules Millas investigates the highly ambivalent attitudes in Greece and Turkey towards 'the West' and, as part of this, the antagonistic relationship between these two countries within the East-West 
continuum. His point of departure are critical positions in Greece and Turkey towards the EU during the financial crisis and the refugee crisis respectively. He traces what he calls 'Levantine Occidentalism' in history and current affairs: an anti-Western discourse that is in part a reaction to long-standing Western Orientalism, but also serves manifest aims in current political and economical bargaining with the EU. Millas' wide-ranging contribution focuses in particular on contradictions and unresolved ambivalences in Greek and Turkish positions towards the East, such as the fact that they both see themselves as part of Europe and have embraced, at various junctures, an agenda of Western-style modernisation, while at the same time rejecting European influences as alien and corrupting. Of particular interest for him is also the subsidiary East-West conflict between Greece and Turkey, which is as much cultural as it is political. Overall, the comparison of their respective positions makes a rich case study for shifting significations on the spectrum of auto- and hetero-images.

After clarifying in theoretical terms how the study of historical myth can be a fruitful approach within imagology, Zrinka Blažević takes the exposed position of Croatia on the Balkan route during the refugee crisis as her point of departure to analyse the multiple uses, functions and meanings of the antemurale Christianitatis myth in Croatia's historical imagery and cultural memory. The heroic self-image of Croatians as guardians of Western civilisation and as a bulwark in the defence of Christendom against an Islamic threat has been a central part of Croatian identity narratives since the sixteenth century. While nineteenth-century Slavophilia furnished an alternative counter-myth (Croatia as a civilisational bridge or crossroads), the bulwark trope was reactivated at various junctures both during Tito's Yugoslavia and since 199o; today it is a cornerstone of anti-immigrant rhetoric in Croatian right-wing circles. Blažević's analysis stresses the considerable symbolic and ideological potential of the myth as well as its polysemic and multimedial qualities.

In Part 4 'Stereotyping in the Media' Luc van Doorslaer addresses the underrepresentation of journalistic discourse in imagology and explores the potential of translation studies to analyse how journalism produces and distributes political and cultural stereotyping. Given the omnipresence of journalism in the media world and its enormous influence on public discourse this is an important field of further studies, especially as 'default stereotyping' and simplistic binary dichotomies are becoming, as van Doorslaer demonstrates, more prevalent in journalism the less journalists are informed about the subject on which they write. The focus in translation studies on processes of intercultural transfer and also of selecting, de-selecting, re-editing and rewriting offers great potential for better understanding stereotyping in journalism, as 
these processes are also central to journalistic practice. He illustrates this with examples from sports journalism and the stereotypical representation of Germany in the British and Turkish press; the contribution closes with a call for a more systematic investigation of this promising new interdisciplinary field of enquiry.

Wulf Kansteiner turns his attention to another highly influential medium, prime time television. He detects and describes processes of othering in Germany's longest running and most popular crime series, Tatort or Scene of the Crime, and in his analysis links these to prevalent attitudes during the so called refugee crisis of 2015. He discusses the constructions of alterity in a number of highly ambivalent instalments from the early 2000 s which thematize issues of migration and the place of Jews in contemporary German society. Even as this critically acclaimed and socially engaged series intended to raise viewers' awareness and compassion for the plights of migrants coming to Germany, it was predicated on a plot structure which requires victims and perpetrators, and is thus forced to cast migrants in one of these roles. The efforts to turn the crime series into a self-reflexive study of racism in German society are thus subverted by its genre conventions, and unintentionally xenophobic or antisemitic prejudices can be raised. Kansteiner in conclusion calls for a 'mobility turn in memory studies and the politics of memory', a new approach that values migration memories within the German host culture and beyond.

Social media are the new digital public sphere and as such prime opinion-makers. Their influence in distributing, enforcing and amplifying national and other stereotypes can hardly be overestimated, but requires more detailed empirical analysis. Raúl Sanchez Prieto's contribution presents and tests a practical, empirical text-linguistic approach. His corpus-based case study investigates Facebook conversations about Spain during the financial crisis in six selected countries from Northern, Southern and Eastern Europe. His approach, which combines text-linguistics with sentiment analysis research, effectively identifies the presence, prevalence and actional nature of both positive and negative stereotypes.

The contributions in Part 5 'The economic crisis in literature' discuss the potential of contemporary fiction to offer a critical counter-discourse to the financial crisis of 2008 and the austerity politics imposed as a consequence by the EU and the International Monetary Fund. Ana María Fraile considers the nuances of how fictional narrative can represent the economic, political, social and cultural effects of recent European upheavals. She discusses five Spanish crisis novels, published between 2012 to 2015, which show how the EU's crisis management during the economic crisis and its aftermath reactivated and 
mobilised stereotypical constructs of the relationship between Spain and other European countries such as Holland and Germany. These novels reflect selfand hetero-images about Spain but also, most notably, meta-images, which reflect how a nation believes to be perceived by others. Fraile discusses how these texts employ satire and irony as well as a critical mobilisation of cultural memory. She argues that these novels go beyond mere critique and analysis and also offer a narrative ethics of resilience in times of crisis, which might contribute over time to overcoming ingrained stereotypes and offer more optimistic perspectives of a common European citizenship.

In a similar vein Aidan O'Malley examines three recent novels by the prominent Irish author Paul Murray that constitute a humorous panorama of contemporary Ireland by charting the ascent and supposed death of the so-called Irish Tiger. With inward migration from Europe being a defining feature of the boom years that preceded the economic crisis, O'Malley demonstrates how these novels employ non-Irish European characters to dramatize the Irish iteration of late capitalism. Stereotyping fundamentally renders reality fictional, and in Murray's novels the reader witnesses how the stereotyping of European immigrants was essential to the operations of the phantasmagoric Celtic-Tiger Ireland; amongst other things, it translated them as exploitable. However, as this contribution also shows, the comic exaggerations employed in the satirical representation of this spectral dynamic in Murray's most recent novel, The Mark and the Void, gesture back towards, and repeat, the stereotyping the novel is explicitly critiquing.

The conference on which this book is based was a flagship event of Trinity College's university-wide interdisciplinary research theme Identities in Transformation. ${ }^{8}$ This research theme, established in 2013 , is a collaborative platform for investigating shifting identities in Ireland, Europe and the world in a period of accelerating change. In doing this, it serves as a forum for public humanities and seeks to contribute to addressing urgent societal challenges of our time.

The conference was held in conjunction with the Social Sciences and Humanities Working Group of the Coimbra Group of European Universities. As a network of 41 leading European universities the Coimbra Group brings together perspectives and expertise from all over Europe. Its Social Sciences

8 More information on the Identities in Transformation Research Theme can be found at https://www.tcd.ie/ trinitylongroomhub/themes/identities/. 
and Humanities Working Group investigates in particular questions of cultural identities and memory cultures, of migration, integration and inclusion and related challenges facing Europe. ${ }^{9}$ The Research Theme and the Working Group provided rich and fruitful contexts for the investigation of the topics that this volume engages with.

The editors of this book wish to express their gratitude to the following: To the team of the Trinity Long Room Hub Arts \& Humanities Research Institute, especially its then Director Jane Ohlmeyer and its Executive Director Caitriona Curtis, for their hospitality and organisational support, and the Trinity Long Room Hub Research Incentive Fund for generous financial support. To Dr Jonathan Johnston, whose perfect planning, great organisational skills and good humour ensured that everything went smoothly. To the Steering Committee of the Identities in Transformation Research Theme and the Social Sciences and Humanities Working Group of the Coimbra Group for their contributions to the concept and programme. And last, but by no means least, a very special and warm 'Thank You' to Dr Beate Schuler, member of the Provost's Council, great friend and generous supporter of the Humanities at Trinity College Dublin and of the university in general, as main sponsor of the conference.

\section{Bibliography}

Beller, Manfred, Joep Leerssen (eds) (2007). Imagology. The cultural construction and literary representation of national characters. A critical survey (Amsterdam: Rodopi). Billig, Michael (1995). Banal Nationalism (London: Sage).

Flowerdew, John, John E. Richardson (eds) (2017). The Routledge Handbook of Critical Discourse Studies (London: Routledge).

Leerssen, Joep (2000). 'The rhetoric of national character. A programmatic survey', Poetics today, 21, pp. 265-9o.

Leerssen, Joep (2016). 'Imagology. On invoking ethnicity to make sense of the world', Iberic@l. Revue d'études ibériques et ibéro-américaines, 10, pp.16-31.

Reisigl, Martin (2017). 'The Discourse-Historical Approach', in John Flowerdew, John E. Richardson (eds), The Routledge Handbook of Critical Discourse Studies (London: Routledge), pp. 44-59.

9 The Coimbra Group is an association of 41 long-established, multidisciplinary and research-intensive universities from across Europe. For more information see https://www.coimbra-group.eu/. 
Reisigl, Martin, Ruth Wodak (2009). 'The Discourse-historical Approach (DHA)', in Ruth Wodak, Michael Meyer (eds) (2009 [2001]), Methods of Critical Discourse Analysis (London: Sage), pp. 87-121.

Van Dijk, Teun A. (2001). 'Critical Discourse Analysis', in Deborah Tannen, Heidi E. Hamilton, Deborah Schiffrin (eds), The Handbook of Discourse Analysis (New Jersey: Blackwell), pp. 352-371.

Wodak, Ruth (2017). 'Discourses about nationalism', in John Flowerdew, John E. Richardson (eds), The Routledge Handbook of Critical Discourse Studies (London: Routledge), pp. 403-42O. 
PART 1

\section{History and Identity Politics}




\title{
Confronting the Other/Perceiving the Self
}

\author{
National Historiographies and National Stereotypes in \\ Twentieth-Century Europe
}

Stefan Berger

\begin{abstract}
This contribution deals with the relationship between national historiographies and national stereotypes in twentieth-century Europe. It argues that this relationship was extraordinarily diverse and complex and produced a range of different scenarios. After briefly recalling the role and function of stereotypes and after providing the briefest of introductions to national history writing, it presents five brief case studies. They are, first, the contributions of British and German historians to national stereotyping during the First World War. Secondly, the contribution recalls the stereotyping that followed from the research of so-called Volksgeschichte in Germany during the interwar period. Thirdly, the need to nationalise territories in East-Central and Eastern Europe that had previously not belonged to the nation state gave rise to the formation of new national stereotypes after the end of the Second World War. Fourthly, the hypernationalism of the first half of the twentieth century threw a range of national historical master narratives into a severe crisis after 1945 and created the need to reframe those narratives in the post-Second World War world. The final case study deals with a similar need to recast national historical master narratives after the end of the Cold War from the 199 os onwards.
\end{abstract}

\section{Introduction}

Standing on Gianicolo Hill overlooking Rome one is confronted with the monument to Giuseppe Garibaldi, unveiled in 1895. Garibaldi was, of course, one of the central heroes of the Risorgimento - an archetypal romantic figure fighting the cause of national unity and liberty not just in Italy but also in Latin America. He sits alongside a whole range of other romantic liberators of allegedly unfinished or repressed nations in the pantheon of nineteenth-century national movements. The nation states they were striving for and that, in many cases, were eventually to emerge from history took great care to present their heroes,

(C) STEFAN BERGER, 2021 | DOI:10.1163/9789004436107_003

This is an open access chapter distributed under the terms of the CC BY-NC-ND 4.0 license. 


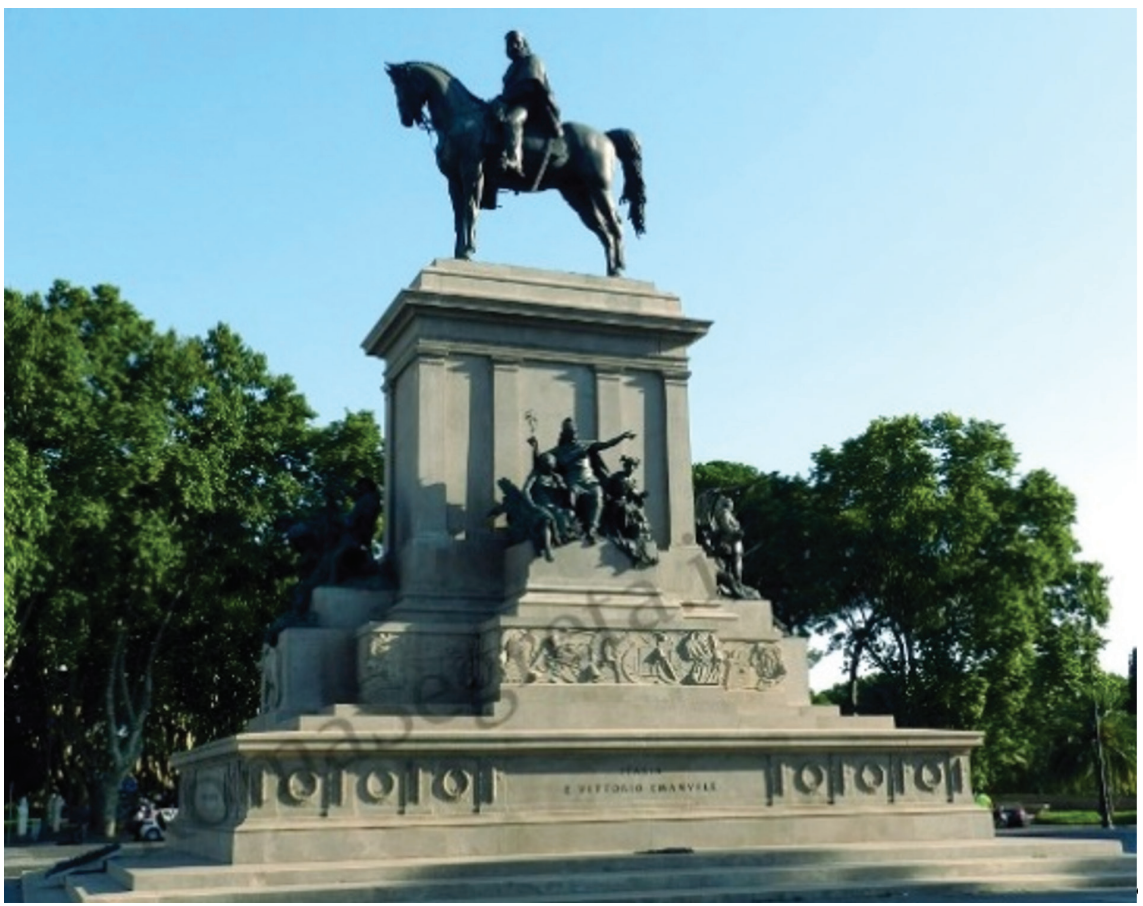

FIGURE 1.1 Statue of Garibaldi on the Gianicolo hill in Rome

their heroism and the heroic times they shaped in the best of lights in their museums, their monuments and their history books. This is certainly true for Garibaldi: the incredibly tall statue of Garibaldi on horseback on the Gianicolo depicts a victor - majestic and glorious, a true father of the nation. It recalls all the myths of the Risorgimento on which the official Italy thrived after its unification, even if it, by and large, ultimately failed to 'make Italians', at least before the First World War. ${ }^{1}$ Perhaps because the Italian national elites were struggling hard to 'make Italians', they were particularly wary of protecting their national myths and the stereotypical representation of historical events they entailed. Professional historians and historical writing were sometimes seen as a threat to those "beautiful legends", as they were called by Giovanni Giolitti who closed the archives of the Risorgimento because he did not want historians to destroy those myths. ${ }^{2}$

This may seem an extreme case of an adverse relationship between national historiographies and national stereotypes in twentieth-century Europe, and in

1 Massimo d'Azeglio, another pioneer of Italian unification is credited with saying: "We have made Italy. Now we have to make Italians." See Hom (2013).

2 Cited in Laven (2006), p. 270. 
fact, as I shall argue in this article, this relationship was extraordinarily diverse and complex and produced a range of different scenarios. After briefly recalling the role and function of stereotypes and after providing the briefest of introductions to national history writing, I will present five case studies in which the relationship between national stereotyping and perceptions of national history are particularly acute. They are, first, the contributions of British and German historians to national stereotyping during the First World War. Secondly, I will recall the stereotyping that followed from the research of so-called Volksgeschichte in Germany during the interwar period. Thirdly, the need to nationalise territories in East-Central and Eastern Europe that had previously not belonged to the nation state gave rise to the formation of new national stereotypes after the end of the Second World War. Fourthly, the hypernationalism of the first half of the twentieth century threw a range of national historical master narratives into a severe crisis after 1945 and created the need to reframe those narratives in the post-Second World War world - with the help of several stereotypical images. My final case study will deal with a similar need to recast national historical master narratives after the end of the Cold War from the 199os onwards. I will conclude with some remarks on the relationship between national stereotyping and national history writing.

\section{Some Preliminary Thoughts on Stereotypes and on National Histories}

Katy Greenland has defined stereotypes as "probabilistic, generalised representations of any social group". ${ }^{3}$ They play an important role in social cognition, as they allow people to categorize and thereby simplify the world around them. Their effects on perception, thought and behaviour is considerable. Bias and prejudice are an integral part of stereotyping leading to the frequent denigration of 'others'. The more social groups suffer from anxiety about other groups, the more they will practice negative stereotyping. These stereotypes are often highly abstract, which helps to make their cores more durable, as they are very difficult to destabilise with specific counter-examples. At the level of abstraction at which stereotypes operate, specific examples can always be dismissed as the exception to the rule.

A close analysis of national histories leads to the conclusion that they are often characterised by positive auto-stereotypes and negative stereotypes

3 Greenland (2000), p. 15 . 
about 'others', which can be both external and internal. ${ }^{4}$ Stereotypical ideas of 'the other' are due to deep insecurities about national identity. As Peter Fritzsche has argued:

The relationship between victimhood and violence is embedded in most national historiographies [...]. [The national idea, S.B.] is first conjured up as being under threat. And it is this state of alarm that produces the energy to override competing identities, often violently. Violence is inscribed in the national narrative because the nation imagines itself first and foremost as a collective good that is incomplete and imperilled. In many ways, the national narrative must sustain itself by reproducing its own state of jeopardy. National histories tremble as a result. ${ }^{5}$

To take the example of Germany after unification of 1871, here national histories contributed to constructing a whole string of internal and external enemies in order to strengthen an altogether insecure national 'we' group that could not even produce a majority for unification in the first all-German parliament. Hence the Catholics and the Socialists were picked upon as two groups whose primary loyalty did not lie with the German fatherland, but rather with the Pope in Rome and with international socialism respectively. They were denounced as 'fellows without a fatherland' and the national 'we' group could define itself more strongly against those 'out' groups. Alongside the internal enemies, German nationalism after 1871 had many external enemies, especially the so-called 'hereditary enemy ' of France, regarded as a country that wanted to weaken, dismember and humiliate Germany for many centuries. Britain was stereotyped as 'perfidious Albion' that was double-faced and could not be trusted. Its economistic mentality only looked for profit and was allegedly unable to produce any true culture (Kultur). Russia and many of the East European peoples were denounced as Slavs, who allegedly were culturally much inferior to the Germans and whose civilisation depended partly on medieval German colonisation eastwards. Again, the external enemies also served the purpose of re-assuring an insecure German 'we' against its immediate surroundings. ${ }^{6}$

4 This observation is based on the European Science Foundation project about the writing of national histories in modern Europe which ran between 2003 and 2008 and involved more than 25 o scholars from 29 European countries. It was the basis for a nine-volume 'Writing the Nation' series with Palgrave MacMillan, the last volume of which attempts a synthesis. See Berger with Conrad (2015).

5 Peter Fritzsche, 'National Narrative and Untimely Death', keynote address to the final conference of the NHIST programme, Manchester, 23-25 October 2008.

6 This is discussed at length in Berger (2005a), chap. 4. 
Historiography contributed significantly to re-enforcing such stereotypes, as history was one of the most important ingredients in shaping national master narratives. Despite the victory of 'scientificity' in nineteenth-century historical writing, ${ }^{7}$ historiographical nationalism was at its strongest arguably in the century between the 185 os and the 1950s. When history became a Wissenschaft, it drew the lines more firmly to other disciplines, and, above all, to 'amateur' historical writing. The professionalisation and institutionalisation of historical writing, often state-driven, was accompanied by an exclusion of 'the amateur'. It was now a particular method and long years of university study, in which this method was acquired, and then long years of apprenticeship as a professional historian in the archives and libraries ultimately 'made' the historian. ${ }^{8}$ Only where such state-driven professionalisation processes were weak, such as in Britain, did amateurs continue to play a bigger role in the history business. ${ }^{9}$ Ultimately, however, professional historians everywhere claimed (very successfully overall) that they were the only ones who could speak authoritatively about the past, but this claim did not prevent them from strong political commitments, including a strong nationalist activism, both on behalf of nation states and on behalf of national movements seeking to create a nation-state. ${ }^{10}$ Their scientificity went hand in hand with historiographical nationalism and was often strongly influenced by stereotypes of self and others. Historians did not prove immune to the general cognition processes of stereotyping.

In fact I would like to use the following five case studies to demonstrate that academic national history writing could and did transport national stereotypes more often than it questioned and destroyed them. It could do both, of course, but there are famous examples of the dangers of destroying those stereotypes dangers to the historians' career and sometimes life. Take the example of the young Gyula Szekfü in Hungary who was in the middle of the so-called Rákóczi controversy of 1913. Szekfü had published a book that demolished the national hero Francis II. Rákóczi and presented him as a rejected and bitter politician who, towards the end of his life, recognised his own failures. This interpretation was itself driven by the political sentiments of Szekfü, who was pro-Habsburg at the time. Yet the Hungarian nationalists criticised this interpretation viciously and almost destroyed the promising young career of the historian who would later become one of the most distinguished among his profession in Hungary. ${ }^{11}$

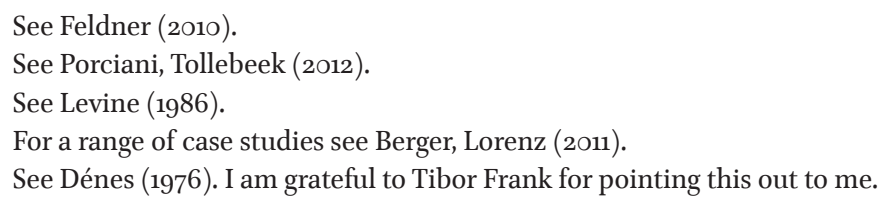


Or take the example of the German historian Emil Ludwig, who did not have a university position, but was so successful in his writing of political biography that he could live extremely well as an independent author in the Weimar Republic. Amongst those biographies were strongly critical ones of Bismarck and of Wilhelm II. Especially the former was still a revered hero among most Germans, including most professional historians. The vitriolic attacks on Ludwig were unceasing and the National Socialists were to burn his books. By that time, however, he had already withdrawn to exile in Switzerland. ${ }^{12}$ As the cases of Szekfü and Ludwig demonstrate, it was easier to live with, condone and even promote stereotypes. As the following five case studies seek to demonstrate, this is precisely what they did, especially when they felt called upon to defend their respective nation states against others.

\section{3 \\ Historians as Purveyors of Stereotypes in Twentieth-Century Historiography}

Our first case study relates to the historians' agency in and around the First World War. British historians before 1914 were divided between those holding pro-German and those holding anti-German sentiments. Their positions were often based on stereotypes of what was the essence of the German nation: whereas the pro-German camp argued that the German Mensch was modern, progressive and educated (gebildet), the anti-German camp held that the German was born with a Pickelhaube and was inherently militarist, aggressive and authoritarian. These traits were then often historicised, i.e. history became an argument to bolster particular stereotypes of Germany. At the outbreak of the First World War, many pro-German historians were hugely disappointed as their particular vision of what 'the German' was, seemed to be drowned out by their opponents' vision of 'the Hun'. British historians during the First World War repeatedly came out with stereotypical accusations of Prussianism and posited Prussian militarism against English liberty, i.e. they juxtaposed a negative stereotype of the other with a positive auto-stereotype. ${ }^{13}$ A particularly interesting and after 1918 influential position was taken by William Harbutt Dawson. Like many of his fellow pro-German historians he was deeply shocked by the nationalist pro-war sentiments in Germany, and he came up with an ingenious solution to the problem, i.e. the theory of the two Germanies. A

\footnotetext{
12 See Ullrich (2005).

13 See Wallace (1988).
} 
long-standing divide had been going through Germany pitting the south against the north and the Rhineland against Prussia. Whereas Prussia and the North, Dawson conceded, had aggressive, militarist and antiliberal traits, the south was progressive, modern and the harbinger of a universalist humanistic ideal of Bildung. ${ }^{14}$ Such stereotypes became the intellectual justification for a new positive perception of Weimar Germany: the positive Germany had allegedly defeated its negative other and now needed the support and friendship of Britain again.

If we look at German historiography, it was strongly engulfed in the outbreak of hyper-nationalism at the beginning of the war, which engulfed almost all of the intellectuals in Germany. ${ }^{15}$ They again worked strongly with stereotypes, contrasting German discipline and Kultur with Western shallowness, Slav barbarity and French decadence. All of the tropes that were used in this negative stereotyping of the 'enemy' in the war had already been well established before 1914. It was easy to fall back on them in war-time. Thus, for example, Gerhard von Schulze Gaevernitz, an economist well known also for his historical work, among other topics on the British historian and writer Thomas Carlyle, argued in 1915: "The Anglo-Saxon, in his highest form, is a man as hard as steel and of the toughest constitution, kalt wie Hundeschnauze, completely lacking in artistic temperament, the type who aims to subordinate beauty and colour to brutal numbers [...]."16 Endless other examples could be cited. Friedrich Meinecke published a book justifying the German declaration of war and using crude stereotypes to contrast an allegedly higher German form of humanity with the humanity of the West which he identified with uniformity, egotism and degeneracy. ${ }^{17}$ Overall, most German historians backed the war effort right up to the end, and it is no surprise that many of them even peddled the 'stab-in-theback' myth after 1918 and supported an authoritarian redirection of German politics away from Weimar and its liberal foundations.

With our second example we stay with German historiography, as it saw the rise of so-called Volksgeschichte as a direct result of the lost war in the interwar period. Volksgeschichte was many things, but it essentially amounted to a racialisation and biologisation of history writing. ${ }^{18}$ The strong state-orientation of German historiography before 1914 was no longer seen as being sufficient to underpin a powerful sense of German national identity. Hence many younger

\footnotetext{
14 See Berger (2001).

15 See Von Ungern-Sternberg von Pürkel, von Ungern-Sternberg (1996)

16 Cited in Stibbe (2003), p. 249. See also, more generally, Stibbe (2001).

17 See Meinecke (1915).

18 See Oberkrome (1993); Lambert (1995); Schöttler (1997); Schulze, Oexle (2000).
} 
historians turned to the people, the Volk, but not in a democratic political sense. Instead they constructed it in a racial, biological sense. In their attachment to historiographical nationalism, proponents of Volksgeschichte stood on the same platform as their often older colleagues still attached to statism. Both camps lend their pens to the service of a revision of the Versailles Treaty in the interwar period. ${ }^{19}$ Race was undoubtedly a far more identitarian category than state, and the racial ideal, upheld by Volksgeschichte, incorporated a whole host of stereotypical ideas of self and other. Thus, there was, for example, the centuries-old idea of the 'civilising mission' of the Germans in the East which was strongly related to the stereotype of the Slavs as not being capable of producing civilisation. This gave rise within Volksgeschichte to ideas about German 'cultural territory' (Kulturboden): numerous German historians, including the young Werner Conze, began writing histories of the German settlements in the East hoping to deliver the proof of German cultural and often racial superiority vis-à-vis the Slav population in Eastern Europe. From there it was but a small step to German historians contributing to the infamous Generalplan Ost in the Second World War, which foresaw vast population moves and the settlement of Germans in Europe's east, with the Slav population playing the role of de facto slaves to the German master race. ${ }^{20}$ Ostforschung used stereotypes to justify the cultural-racial expansion of Germans eastwards, but it was paralleled by Westforschung, which sought to justify the annexation of parts of the Low Countries into a greater Germany during the Second World War. Here, just as in Ostforschung, stereotypes played an influential role in structuring research agendas and underpinning historical analysis. Thus, Wolfgang Petri referred to common linguistic, cultural and ethnic characteristics of the Dutch and the Germans using well-known stereotypes about national character to bolster his historical interpretations. ${ }^{21}$

Our third case study looks at the recasting of national historical master narratives in many European nation states at the end of the Second World War. ${ }^{22}$ Stereotypes were once again crucial in allowing those narratives, many of which had been damaged in and by the war, to be revived after 1945. If we start with Germany, the defeated country had to reject almost everything that the National Socialists had stood for. The anti-fascism of the Communist German Democratic Republic (GDR) legitimated itself in total contradistinction to National Socialist rule. Yet underneath the anti-fascist gloss, sometimes

\footnotetext{
19 See Harvey (2003), chap. 6.

20 See Heim, Aly (1991); Schönwalder (1992); Haar, Fahlbusch (2005).

21 See Dietz, Gabel, Tiedau (2003).

22 See Berger $(2005 \mathrm{~b})$.
} 
very traditional notions of German history and stereotypical perceptions of Germanness continued in the GDR and were bolstered by its Marxist-Leninist historiography. ${ }^{23}$ All over Eastern Europe, the national histories together with the national stereotypes on which they rested were simply painted red, but they remained essentially unchanged beneath this coat of red paint, which over time, in many countries, showed severe signs of deterioration, making the older nationalist narratives and stereotypes re-appear from underneath. Stereotypical ideas about national peculiarity and heroic ideas of the nation were thus strongly coming back to the surface after the collapse of communism from the late 1980 on onwards. ${ }^{24}$

In the capitalist Federal Republic of Germany (FRG) there was one very important ideological bridge that allowed many supporters of Nazism to cross over into the post-war camp of 'the West' and that ideological bridge was anti-Communism. From the perspective of many in the early FRG, if the National Socialists had been wrong about almost everything, they had been right in their anti-Communism. The Cold War confirmed this, and West German historians could use ideas around the Asianness of Russia and the Soviet Union to posit it as a negative other to the idea of the occident (Abendland) that became popular again with some West German historians in the late 1940 and 1950s. A good Germany, connected, above all, to the conservative military resistance to National Socialism associated with 20 July 1944 (almost all of those conservative military officers had excellent anti-Communist credentials), could be constructed against a stereotypical other - the one-dimensional communist who, through the theory of totalitarianism, was connected to the ultimate evil, National Socialism. Christianity, antiquity and humanism were seen as the defining features of Europe, and the Soviet Union and much of Eastern Europe were decidedly not part of it. Democratic anti-Communism merged with traditional anti-Slav and anti-Russian prejudices, and, in countries such as the FRG, some historians harked back to older stereotypical ideas about German superiority vis-à-vis Eastern Europe. ${ }^{25}$

If we turn to Britain we find that some of the most traditional stereotypes about its national history are retained and recast in the post-war period. The existing liberal historical master narrative depicting Britain as the land of liberty, freedom and constitutionalism, the mother of parliaments and progressive, evolutionary change was adapted by left-of-centre historians who

\footnotetext{
23 See Iggers (1989).

24 See Antohi, Trencsényim, Apor (2008).

25 See Schulze (1989), pp. 211f., 266ff. For Schnabel's history writing more generally see Hertfelder (1998).
} 
extended these stereotypical definitions of Britishness to 'the people.'.6 Out of the 'people's war' emerged a 'people's history' that sought to extend British democracy and end its exclusivity in terms of class. The victory of the Labour Party in 1945 made it possible to build the 'homes fit for heroes' that had already been promised at the end of the First World War. The Labour government started a new municipal housing scheme that was to create cheap and affordable housing for many of its working-class voters. It also institutionalised a revolutionary health service system for all citizens in the form of the National Health Service (NHS). The historians, or some of them, especially members of the Communist Party's Historians Group, ${ }^{27}$ delivered the historical national master narratives that went with this political change, and they did so by adapting Britain's very traditional national master narrative, often referred to as Whig history. It now got a little reddish coat to signal an inclusive rather than an exclusive Britain.

In post-war Italy, we find a very similar attempt to adapt what had been the dominant national historical master narrative to the situation after 1945 . Ever since the second half of the nineteenth century the 'beautiful myths' of the Risorgimento had been the basis of Italian constructions of national identity. Fascism had also presented itself as the true inheritor of the Risorgimento as had anti-fascists, e.g. the brothers Roselli. ${ }^{28}$ In post-war Italy the Risorgimento was re-loaded once more. The resistance now inherited the mantle of the Risorgimento and became the key to continuing with positive national histories rooted in stereotypical depictions of the era of Italian unification. ${ }^{29}$

While we can find the retention of traditional stereotypes in the recasting of national historical master narratives after 1945 in large parts of Europe, we can identify no such re-orientation on the Iberian peninsula, as the authoritarian right-wing dictatorships survived the end of fascism in Europe, despite the fact that they had strongly sympathised with fascism in the 1930s and 1940s. Here the occidentalist, Catholic, and familial stereotypes were still shaping the authoritarian historical narratives emanating from those countries until the 1980 os. $^{30}$

Our fifth and final case study considers the renationalisation of historical master narratives after the end of Communism. In post-Communist states we can observe that national historians harked back to positive auto-stereotypes and negative othering - a story all-too familiar from the interwar period. Strong anti-Communism found expression in public history ventures such as

\footnotetext{
$26 \quad$ See Berger (2014).

27 See Kaye (1984); Schwartz (1982); Elliott, Hobsbawm (2010).

28 See Morgan (1999).

29 See Battente $(2000 / 2001)$.

$30 \quad$ See Seixas (1993).
} 
Budapest's House of Terror museum. ${ }^{31}$ Here the stereotypical Communist villain is typically not Hungarian but a foreigner. In the terribly divided historical culture of Ukraine, traditional stereotypes also to this very day and especially in the political crisis of recent years served the purpose of marking the respective 'other': the 'Asian' Russian and the Ukranian as Western dupe. ${ }^{32}$ Excluding Russians as Asians from the polity has also been a standard trope in many of the Baltic states. Estonian historians have been prominent in the Estonian revolution of the late 1980s and early 199os resurrecting ideas of national history and heritage from the interwar period. ${ }^{33}$ This went alongside the rediscovery of right-wing political leaders of the interwar period who have been re-inserted into the historical pantheons. This is true for István Tisa in Hungary, ${ }^{34}$ as well as for the anti-Semite Symon Petljura in the Ukraine. ${ }^{35}$ The Polish museum wars that have been raging for around two decades also testify to the impact of stereotypes on the master narrative of a Catholic, nationalist and traditionalist Poland.

The growth of stereotypical images in historical master narratives cannot only be observed in post-Communist East European societies. It is equally true for separatist movements from western multinational states such as Scotland in the UK or Catalonia in Spain, or, indeed, Flanders in Belgium. The civic leftwing nationalism in Scotland often prides itself in being primarily political, but it nevertheless constantly appeals to and mobilises the cultural heritage and the cultural roots of Scotland. A collection on Scottish history from 1992, aimed not just at an academic audience, starts: "Scotland's history is important. It gives us as individuals and as members of Scottish society a vital sense of where we are and how we got here." 36 The Catalan National History Museum in Barcelona is full of positive auto-stereotypes about the country and its people, whilst the rest of Spain is the absent 'other' in the museum. The Flemish nationalists around Bart de Wever, himself a trained historian, are championing an autonomous history of Flanders building on all the stereotypical Flemish myths, whilst Henri Pirenne's vision of a Belgium as a bridge between the Romanesque and Germanic cultures has long been out of print in Belgium. ${ }^{37}$

\footnotetext{
31 See Apor (2010).

32 See Kuzio (2005).

33 See Must (2010).

34 See Trencsényi, Apor (2008), p. 45.

35 In May 2008, on a visit to the Ukranian national history museum in Kiev, the author was surprised to see such a positive depiction of Petljura.

$36 \quad$ Donnachie, Whatley (1992), p. 1.

37 I am grateful to Jo Tollebeek for pointing this out to me.
} 
In recasting a wide variety of national histories after the end of the Cold War, stereotypes have often been used to depict an idealised norm, against which the national history is then measured. Take, for example, Germany's 'search for normality' after reunification in 1990. ${ }^{38}$ Heinrich August Winkler's attempt to provide the country with a new master narrative that is measured against the normative ideal of 'the 'West' is a good example of this tendency. ${ }^{39}$ And conservative British historians have worked for some time to prepare the country for Brexit. Thus David Starkey, in his 2001 Medlicott lecture, already lamented a loss of identity and history inside the European Union: "maybe we have a future as a series of disparate regions of the European Union [...]. But where a history - where an English history fits in [...] a sense of England as a place that once existed, that once mattered, that once was glorious - I'm really not sure."40 The Brexit camp relied heavily in its campaign on positive auto-stereotypes regarding Britain and 'its' Commonwealth. Britain allegedly fought alone in the Second World War. Its dead, soldiers and civilians, it was often argued, did not die for Britain being subsumed in a European Union allegedly dominated by Germany. This type of argument strongly appealed to a very traditional negative stereotype of the German 'other' in post-Second World War Britain.

\section{4}

\section{Conclusion}

Scientific history can break stereotypes and it can rely on stereotypes. The susceptibility of historians to stereotypes is certainly crucial to the myth-making aspects of national histories that have been at the centre of attention in this article. As the above case studies have sought to demonstrate, time and again, throughout the twentieth century, national historians used narrative frames that were deeply indebted to stereotypes. The binary construction of positive auto-images with negative images of the 'other' contributed to the construction of national historical master narratives that owed much to stereotypes. If national histories have been an important part of constructions of national character, then stereotypes have been an essential ingredient of notions of national character. We have observed above that stereotypical images of the 'other' were most strongly mobilised at times of conflict, including wars, incidents of ethnic cleansing and post-war reconstruction periods.

\footnotetext{
$38 \quad$ See Berger (2003).

39 See Berger (2010b).

40 See Starkey (2001).
} 
The above reflections are rather essayistic and impressionist, but if they are correct in assuming an important impact of stereotypes on grand historical narratives of nation, we need to examine this much more systematically. As Mark Knights has stated:

History and social psychology share interests in the social sphere, the arts of persuasion and the formation of attitudes. As a result, both disciplines are interested in the construction, manipulation, dissemination and evolution of stereotypes and the prejudices on which they feed. ${ }^{41}$

We thus would need to examine the language of the historian with the tools from social psychology in order to arrive at a better understanding of how and with what purpose those stereotypes are manipulated and disseminated, and how they have evolved over time. Those teaching rhetoric in ancient Greece and Rome had already been well aware of the usefulness of negative stereotyping to put down an adversary. It is about time for the history of historiography to buckle down and examine historical narrative closely to find out about the subtle and not-so-subtle use of stereotypes in historical writing.

\section{Bibliography}

Antohi, Sorin, Balázs Trencsényi, Péter Apor (eds) (2008).Narratives Unbound. Historical Studies in Post-Communist Eastern Europe (Budapest: Central European University). Apor, Peter (2010). 'Eurocommunism. Commemorating Communism in Contemporary Eastern Europe', in Małgorzata Pakier, Bo Stråth (eds), A European Memory? Contested Histories and Politics of Remembrance (Oxford: Berghahn), pp. 233-246.

Battente, Saverio (2000/2001). 'Nation and State Building in Italy. Recent Historiographical Interpretations', Journal of Modern Italian Studies 5, pp. 310-321 and 6, pp. 94-105.

Berger, Stefan (2001). 'William Harbutt Dawson and Germany in the Interwar Period', English Historical Review 116.1, pp. 76-112.

Berger, Stefan (2003). The Search for Normality. National Identity and Historical Consciousness in Germany since 180o, 2nd edn (Oxford: Berghahn).

Berger, Stefan (2005a). Germany. Inventing the Nation (London: Edward Arnold).

Berger, Stefan (2005b). 'A Return to the National Paradigm? National History Writing in Germany, Italy, France and Britain from 1945 to the Present', Journal of Modern History 77.3, pp. 629-678.

$41 \quad$ Knights (2014), p. 242. 
Berger, Stefan (2010). 'Rising Like a Phoenix. The Renaissance of National History Writing in Britain and Germany since the 1980s', in Stefan Berger, Chris Lorenz (eds), Nationalizing the Past. Historians as Nation-Builders in Modern Europe (Basingstoke: Palgrave MacMillan), pp. 426-451.

Berger, Stefan (2014). 'From the English isles to the history of four nations. National history writing in Britain in comparative perspective' in Joseba Agirreazkuenaga Zigorraga, Eduardo J. Alonso Olea (eds). Estatu-nazioen baitako nazioak. Naziogintza kulturala eta politikoa, gaur egungo europan (Bilboa: Editorial Base), pp. 11-26.

Berger, Stefan, Chris Lorenz (eds) (2010). Nationalizing the Past. Historians as NationBuilders in Modern Europe (Basingstoke: Palgrave MacMillan).

Berger, Stefan with Christoph Conrad (2015). The Past as History. National Identity and Historical Consciousness in Modern Europe (Basingstoke: Palgrave MacMilllan).

Dénes, Iván Zoltán (1976). A „realitás” illúziója. A historikus Szekfü Gyula pályafordulója (Budapest: Akadémiai Kiadó).

Dietz, Burkhard, Helmut Gabel, Ulrich Tiedau (eds) (2003). Griff nach dem Westen. Die 'Westforschung' der völkisch-nationalen Wissenschaften zum nordwesteuropäischen Raum, 1919-1960 (Münster: Waxmann).

Donnachie, Ian, Christopher Whatley (1992). 'Introduction', in Ian Donnachie, Christopher Whatley (eds), The Manufacture of Scottish History (Edinburgh: Polygon).

Elliott, Gregory, Eric Hobsbawm (2010). History and Politics (London: Pluto Press).

Feldner, Heiko (2010). 'The New Scientificity in Historical Writing around 180o', in Stefan Berger, Heiko Feldner, Kevin Passmore (eds), Writing History. Theory and Practice, 2nd edn (London: Bloomsbury), pp. 3-21.

Greenland, Katy (200o). “Cant' Live With Them, Can't Live Without Them”. Stereotypes in International Relations', in Rainer Emig (ed.), Stereotypes in Contemporary Anglo-German Relations (Basingstoke: Palgrave MacMillan), pp. 15-30.

Haar, Ingo, Michael Fahlbusch (eds), German Scholars and Ethnic Cleansing 1919-1945 (Oxford, New York: Berghahn 2005).

Harvey, John L. (2003). The Common Adventure of Mankind. Academic Internationalism and Western Historical Practice from Versailles to Potsdam, Ph.D. Thesis Pennsylvania State University.

Heim, Susanne, Götz Aly (1991). Vordenker der Vernichtung. Auschwitz und die deutschen Pläne für eine neue europäische Ordnung (Hamburg: Hoffmann \& Campe).

Hertfelder, Thomas (1998). Franz Schnabel und die deutsche Geschichtswissenschaft. Geschichtsschreibung zwischen Historismus und Kulturkritik (Göttingen: Vandenhoeck \& Ruprecht).

Hom, Stephania Malia (2013). 'On the Origins of Making Italy. Massimo d'Azeglio and “Fatta L'Italia, Bisogna Fare gli Italiani”, Italian Culture 31.1, pp. 1-16.

Iggers, Georg G. (1989). 'New Directions in Historical Studies in the German Democratic Republic', History and Theory 28, pp. 59-77. 
Kaye, Harvey J. (1984). British Marxist Historians. An Introductory Analysis (Cambridge: Polity Press).

Knights, Mark (2014). 'Historical Stereotypes and Histories of Stereotypes', in Cristian Tileaga, Jovan Byford (eds), Psychology and History. Interdisciplinary Perspectives (Cambridge: Cambridge University Press), pp. 242-267.

Kuzio, Taras (2005). 'Nation Building, History Writing and Competition over the Legacy of Kyiv Rus in Ukraine', in Nationalities Papers 33.1, pp. 29-58.

Lambert, Peter (1995). 'German Historians and Nazi Ideology. The Parameters of the Volksgemeinschaft and the Problem of Historical Legitimation, 1930-1945', European History Quarterly 25, pp. 555-582.

Laven, David (2006). 'Italy', in Timothy Baycroft, Mark Hewitson (eds), What is a Nation? Europe 1789-1914 (Oxford: Oxford University Press), pp. 255-271.

Levine, Philippa (1986). The Amateur and the Professional. Antiquarians, Historians and Archaeologists in Victorian England 1838-1886 (Cambridge: Cambridge University Press).

Morgan, Philip (1999). 'Reclaiming Italy? Antifascist Historians and History in "Justice and Liberty"', in Stefan Berger, Mark Donovan, Kevin Passmore (eds), Writing National Histories. Western Europe since 1800 (London, New York: Routledge), pp. 150-16o.

Meinecke, Friedrich (1915). Die deutsche Erhebung von 1914. Vorträge und Aufsätze (Stuttgart: J. G. Cotta).

Must, Aadu (2010). 'Estonia', in: Ilaria Porciani, Lutz Raphael (eds), Atlas of European Historiography. The Making of a Profession 1800-2005 (Basingstoke: Palgrave MacMillan), p. 80-81.

Oberkrome, Willi (1993). Volksgeschichte. Methodische Innovation und völkische Ideologisierung in der deutschen Geschichtswissenschaft, 1918-1945 (Göttingen, Vandenhoeck \& Ruprecht).

Porciani, Ilaria, Jo Tollebeek (eds) (2015), Setting the Standards. Institutions, Networks and Communities of National Historiography (Basingstoke: Palgrave MacMillan).

Schönwälder, Karen (2002). Historiker und Politik. Geschichtswissenschaft im Nationalsozialismus (Frankfurt a.M.: Campus).

Schöttler, Peter (ed.) (1997). Geschichtsschreibung als Legitimationswissenschaft 1918-1945 (Frankfurt a.M.: suhrkamp).

Schulze, Winfried (1989). Deutsche Geschichtswissenschaft nach 1945, (Munich: Oldenbourg).

Schulze, Winfried, Otto Gerhard Oexle (eds) (2000), Deutsche Historiker im Nationalsozialismus (Frankfurt a.M.: Fischer).

Schwartz, Bill (1982). "The People” in History. The Communist Party Historians' Group, 1945-1956', in Richard Johnson et. al. (eds), Making Histories. Studies in HistoryWriting and Politics (London: Hutchinson), pp. 44-95. 
Seixas, Xose M. Nunez (1993). Historiographical Approaches to Nationalism in Spain (Saarbrücken: Verlag Breitenbach).

Starkey, David (2001). 'The English Historians' Role and the Place of History in English National Life', The Historian 71, pp. 6-15.

Stibbe, Matthew (2001). German Anglophobia and the Great War, 1914-1918 (Cambridge: Cambridge University Press).

Stibbe, Matthew (2003) 'German Historians' View of England in the First World War', in Stefan Berger, Peter Lambert, Peter Schumann (eds), Historikerdialoge. Geschichte, Mythos und Gedächtnis im deutsch-britischen kulturellen Austausch 1750-2000 (Göttingen: Vandenhoek \& Ruprecht).

Trencsényi, Balázs, Péter Apor (2008). 'Fine-Tuning the Polyphonic Past. Hungarian Historical Writing in the 199os', in Sorin Antohi, Balázs Trencsényi, Péter Apor (eds), Narratives Unbound. Historical Studies in Post-Communist Eastern Europe (Budapest: Central European University), pp. 1-100.

Ullrich, Sebastian (2005). "Der Fesselndste unter den Biographen ist heute nicht der Historiker”. Emil Ludwig und seine historischen Biographien', in Wolfgang Hardtwig, Erhard Schütz, Wolfgang Becker (eds), Geschichte für Leser. Populäre Geschichtsschreibung in Deutschland im 20. Jahrhundert (Stuttgart: Steiner), pp. 35-56.

Von Ungern-Sternberg von Pürkel, Jürgen, Wolfgang von Ungern-Sternberg (1996). Der Aufruf an die Kulturwelt. Das Manifest der 93 und die Anfänge der Kriegspropaganda im ersten Weltkrieg (Stuttgart: Steiner).

Wallace, Stuart (1988). War and the Image of Germany. British Academics, 1914-1918 (Edinburgh: John Donald). 


\title{
Claiming a Great Ancient Imperial Past as an Identity Element of a Small Modern Nation
}

\author{
The Case of Lithuania
}

\author{
Zenonas Norkus and Aelita Ambrulevičiūtè
}

\begin{abstract}
Lithuanians are a typical East European modern nation, created by the Lithuanian nationalist movement which emerged in the late nineteenth century. Modern Lithuanian identity is ethnolinguistic, resembling national identities of other Baltic countries. Its distinctive feature is the narrative appropriation of the history of the Grand Duchy of Lithuania, which was a multi-ethnic, multi-confessional and multi-cultural empire which in 1569 merged with Poland in the Polish-Lithuanian Commonwealth. Reminiscences of this great imperial past became an important source of inspiration for Lithuanian foreign policy after the accession of the country to the European Union in 2004. The makers of this policy conceived as Lithuania's mission to 'bring back' to European civilization all former lands of ancient Lithuania. They used the Lithuanian presidency of the Council of the EU in 2013 to materialise these ideas, which became an important contribution to the outbreak of the Ukrainian crisis. The contribution closes with the discussion of other impending crises related to the legacy of the Grand Duchy of Lithuania.
\end{abstract}

\section{Introduction}

The aim of this paper is to contribute to the exploration of the role of national stereotypes and cultural identities to the outbreak of the recent European crises, by providing a case study of the influence of some distinctive features of modern Lithuanian national identity on the foreign policy of Lithuania as a member state of European Union (EU) since 2004. ${ }^{1}$ The list of recent European crises includes the unresolved Ukrainian crisis, which broke out in 2014

1 This project has received funding from European Social Fund (project number 09.3.3-LMT-K712-01-0oo6) under grant agreement with the Research Council of Lithuania (LMTLT).

(C) ZENONAS NORKUS AND AELITA AMBRULEVIČIŪTĖ, 2021 | DOI:10.1163/9789004436107_004 This is an open access chapter distributed under the terms of the CC BY-NC-ND 4.0 license. 
in the wake of the Maidan revolution. The chain of events leading to these outcomes started in the 2013, when Lithuania became the first Baltic State to take the Presidency of the Council of the European Union in the second half of that year.

We do not attempt to estimate the exact share of Lithuania's responsibility for the emergence and ambiguous outcomes of this crisis. We will focus on only one specific question, which is relevant for this task: how to explain Lithuania's zeal on behalf of an Eastern expansion of the EU and NATO and its intransigence against Russia, which is out of proportion with the size of its territory, population and economy? Even a glimpse at the map to find out Lithuania's geographical location is sufficient to get the idea that a tough stance in relations with Russia does not promise much in terms of economic rationality. However, Lithuania is no less an ardent supporter of the 'Europeanisation' and 'Westernisation' of Belarus, Moldova, Georgia than that of Ukraine. It consciously takes the self-inflicted costs of this policy, aiming at minimisation of trade with Russia.

This paper provides 'culturalist' or 'identity-theoretic' arguments, explaining post-communist Lithuania's permanent challenging of Russia with specific features of its national identity, shaped by narratives of its ancient imperial grandeur. We will start with recalling some basic facts about the political history of Lithuania in the very brief first section and by introducing our working concepts. The second section zooms in on the contribution of the influential Lithuanian intellectual and opinion-maker Gintautas Beresnevičius, who made the most influential contribution to the elaboration and dissemination of Lithuania's 'imperialist' mythology. The third section provides an account of the influence of reminiscences of Lithuania's medieval imperial greatness on Lithuania's Eastern foreign policy making after its accession to the EU and NATO in 2004. The concluding section discusses the ambiguous achievements and predicaments of this policy, related to similar claims of Lithuania's more powerful neighbours.

Modern Lithuania is a typical East-European modern nation, created by the Lithuanian nationalist movement which emerged in the late nineteenth century. ${ }^{2}$ Its leaders used the historical opportunity provided by the defeat of East

2 See Hroch (1985). 
European empires in World War I to establish an independent Lithuanian national state in 1918. After two decades of independent development, the Republic of Lithuania was occupied and then annexed by the Soviet Union in 1940, re-emerging as independent state after the dissolution of the occupier state. Actually, the breakup of the UsSR was initiated by Lithuania, which proclaimed its independence on 11 March 1990, and was followed by most former Soviet republics only after the failure of the August coup in 1991.

Lithuania's pioneering role in the dissolution of the USSR provides impressive testimony to the national commitment of modern Lithuanians. In fact, national identity is the most important type of modern identity. "National identities do what collective identities do in general: they are stories that combine a series of events in texts, songs and images which some people recognize as being part of their particular we, i.e. as a collective identity". ${ }^{3}$ What is particular about national identities as specifically modern identities is that these "identity constructions have succeeded in imposing themselves as a hegemonic identity in a territorially bounded political community." ${ }^{4}$ They provide these communities with vertical bonds of solidarity, across different social strata.

National communities may broadly vary in terms of the size of territory and population. Together with the bearers of hegemonic identities in neighbouring Baltic countries (Estonia, Latvia, Finland), modern Lithuanians represent the type of small modern nations. In comparison with these neighbours, Lithuanian national identity stands out by the prominent role of narratives about the medieval polity known as the Grand Duchy of Lithuania (GDL), perceived by modern Lithuanians as their precursor state. Young Estonians, Finns and Latvians read in their school textbooks stories about the Middle Ages, describing their ancestors as victims of foreign conquest and rule by more formidable neighbours. For Estonians and Latvians, these neighbours were Danes and Germans, and for Finns the Swedes. Most up-to-date versions of these textbooks contain the provision that this conquest pre-empted a much worse conquest by Russians and also enabled native peoples to join Western civilisation. Very differently, Lithuanian pupils learn history by reading stories describing them as the progeny of conquerors who created a huge medieval empire. ${ }^{5}$ We will argue that the reminiscences of this imperial greatness is an important driving force behind Lithuania's eastward foreign policies.

3 Eder (2009), p. $43^{2}$.

4 Eder (2009), p. 432.

5 For authoritative accounts representing the contemporary Lithuanian view of the history of GDL see Baronas et al. (2011); Gudavičius (1999); Kiaupa et al. (200o); Kiaupienė, Petrauskas (2009); Rowell (1994). See also Norkus (2018). 

Lithuania's Neo-Imperialist Foreign Policy Doctrine

In the early 2ooos the work of the influential Lithuanian public intellectual Gintaras Beresnevičius (1961-20o6) became an important source of inspiration for the forging of Lithuanian foreign policy. He was a leading Lithuanian scholar in religion studies, specialising in pre-Christian Baltic mythology - a kind of Lithuanian Mircea Eliade. These are titles in English of some of Beresnevičius's works in religious studies: Heavens. The Idea of Post-Human Life in the Ancient Lithuanian Worldview (1990); Religious Reforms of Balts (1995); Cosmos and Sacral Places in the Religions of Lithuanians and Prussians (1998); Palemonas Node. the Peripheric Content of the Palemonas Tale (2003); Lithuanian Religion and Mythology (2004). He also published novels, poems, and numerous essays. In 2003, he published the book The Making of Empire (Imperijos darymas). ${ }^{6}$ It was an exploratory study of the prospects of Lithuanian foreign policy, published on the eve of Lithuania joining the EU and NATO in the following year. It was commissioned by the Institute of International Relations and Political Science of Vilnius university, which is reputed to be the 'think tank' of the Lithuanian government.

In this study, Beresnevičius advanced a grandiose vision of the mission of Lithuania after joining the EU and NATO. He suggested to use these memberships as an opportunity for "the making of empire", which is the title of his most famous book. ${ }^{7}$ According to Beresnevičius, this means becoming the bridgehead and vanguard of the eastward extension of the EU and NATO. More specifically, it means spearheading the export of democracy to the former republics of the USSR. "We have an opportunity to use the current situation to lay the foundation for our own geopolitical bloc, tectonic bloc, to

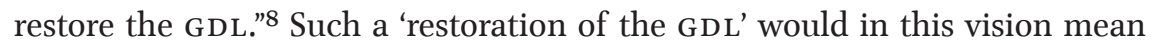
the creation of some kind of community of nations including not only states in the former territory of the GDL, but also Transcaucasian and even Central Asian countries, something distantly similar to the British Commonwealth of Nations. "We must enter the EU as a democratic empire, by acting in the spaces which possibly will exceed the territory of the EU itself."

Interestingly, the ancient Lithuanian empire was for Beresnevičius not synonymous with the GDL. He adopted parahistorical theories about an active

6 Beresnevičius (2003a).

7 Beresnevičius (2003a).

8 Beresnevičius (2003a), p. 72. All translations by the authors.

9 Beresnevičius (2003a), p. 7 . 
participation of Baltic tribes in the events of 'Barbarian invasions' or the Völkerwanderung during the period 200-6oo A.D., with the collapse of the Western Roman empire as its most important world-historic outcome. ${ }^{10}$ Writing about ancient times he therefore avoids exact dates and prefers general descriptions, which anachronistically mix the events of the third to sixth centuries with those of the thirteenth to fifteenth centuries. In this way, the emergence of the GDL in the thirteenth and fourteenth centuries is represented as the continuation of imperialist activities by the ethnic ancestors of modern Lithuanians during much earlier times. The following quotation may serve to provide an impression of his mesmerising style.

As the tillers always prevail in numbers, the ruling military nobility takes over their language and culture. If this culture is higher, than the higher culture is adopted, if it is lower, then the lower one is. This is what adaptation means. Lithuanians in this respect behaved in exactly the same way as Norman, Gothic or Langobard dukes did. The difference is that they did not disappear, and they did not disappear because they had a unitary ethnic base, Ethnic Lithuania. If this ethnic base would have moved and arrived say to the lower Dnieper or the lower Volga, they would have disappeared ruling somewhere in Kiev or Sarai on the very summit of their domination. Barbarians who have created Europe did finish their histories in such a way. Lithuanians are unique among barbarians who have participated in the migration of peoples in that they preserved their ties with their old fatherland, and therefore this base has survived. ${ }^{11}$

Surviving in their ancient motherland, Beresnevičius contends, Lithuanians remain the same 'perennial Barbarians' from Völkerwanderung times, which are flourishing only when they act according to their perennial imperial drive, being in their own element. Otherwise they perform acts of self-destruction or engage in criminal activities.

Obviously, such essentialist views have nothing in common with scholarly historical or social scientific analysis. However, Beresnevičius' aim is not to provide academic analysis, but to construct a political myth useful for the contemporary power elite of Lithuania in inspiring its citizens to bear the costs of playing the self-assumed role of vanguard of the Eastern expansion of NATO and the EU. In this role, Lithuania would challenge semi-authoritarian Russia.

10 See Statkutè de Rosales (2004), Gedgaudas (1972).

11 Beresnevičius (2003a), p. 11f. 
In the struggle for this goal, Lithuania should work to decrease the geopolitical space which Moscow still tries to keep under its control.

Europe needs our empire, I think the US needs it too - both powers will not need much time to understand this, and all their actions show that they understand. [...] With our help Ukraine and Belarus should culturally and politically immediately be integrated into Central Europe; this is the space of GDL; Armenia, Azerbaijan, Georgia should be considered in exactly the same way. The next sphere is Central Asia, going right up to China. $^{12}$

How (if at all) can this breath-taking vision be implemented practically? Are the resources of small Lithuania not too meagre? Obviously it cannot be implemented by the methods used by ancient Lithuanian rulers. Practical measures proposed by Beresnevičius include, firstly, the creation of a Lithuanian Legion. This would be an elite military task force, which the military command of NATO would be free to employ in all 'hot spots' of the world. The beneficial side-effect of this measure would be the reduction of criminality in Lithuania. The legion "would absorb all potential criminals, depressed persons, addicts. If we have the Lithuanian legion, [...] then the dream of each adolescent schoolboy will not be to become a car thief or drug dealer, but a soldier". ${ }^{13}$ Secondly, Beresnevičius proposed to establish a programme of stipends and grants for students, scholars and intellectuals from Belarus, Ukraine and other prospective members of the restored GDL.

While all this costs money, the costs would be comparatively small. All this is an investment into cultivating our 'agents' in these countries. All states which have such political interests and perceive them similarly, have similar foundations and fellowship programs. They shape their image from the inside through future journalists, programmers, statesmen. ${ }^{14}$

In competition with other powers eager to grow their own 'fifth column' in the former Soviet republics, Lithuania has two advantages. As a small state, it cannot be perceived as a real threat (even by Russia). It also can exploit the memories of common victimhood, shared with populations of most Soviet republics.

\footnotetext{
12 Beresnevičius (2003a), p. 75 .

13 Beresnevičius (2003a), p. $5^{6}$.

14 Beresnevičius (2003a), p. $16 f$.
} 
The third proposal is at the same time the cheapest and the most difficult to implement. This is the change of the perception of emigration from Lithuania. Since the restoration of independence, Lithuania's population decreased from 3.7 million in 1989 to 3.5 million according to the general census in 2001, i.e. at the time when Beresnevičius announced his programme for the restoration of the GDL. This decrease was also caused by mortality rates exceeding birth rates since 1994, but emigration is the major cause. It continued also after Lithuania's accession to the EU in 2004, sinking to 2.8 million in 2018. These demographic changes became a matter of common concern in Lithuania around the year 2000. Advancing his programme of the "restoration of the GDL", Beresnevičius made the bold proposal to re-frame the present emigration as a continuation of a perennial trend since Völkerwanderung times, driving Lithuanian imperial expansion. Present-day Lithuanian emigrants should be considered as 'colonists', spearheading the latest wave of Lithuania's imperialist expansion. Emigrant quarters in the cities of the advanced Western countries are equivalents of the military colonies planted by the ancient Lithuanian rulers in Slavic lands.

We should not perceive emigration as a catastrophe, because the contemporary world context and internal movement within the European Union universalize these problems. [...]. We should not impose on emigrants the self-consciousness of a 'lost generation' or a 'broken thread', because in this way we infuse into our diaspora the complex - to break away and not come back. The Jewish diaspora can set the example for our own diaspora, as far as Israel would not be a superpower with its territory. ${ }^{15}$

The ultimate aim of this new Lithuanian imperialism should be Lithuania becoming the leading power in the 'new Europe' - formerly communist East European countries, famously so designated by the US Secretary of Defense Donald Rumsfeld, who praised them for their greater willingness to participate in the American invasion of Iraq in 2003 as compared to older NATO members like Germany and France. According to Beresnevičius' diagnosis, "old Europe"16 is facing its "autumn", ${ }^{17}$ displaying signs of weakness like "cowardly hearts, lack of education, economic hazards, cracks in genofond, exaggerated political correctness which civilisationally supresses ripening of new ideas". 18 The mission

\footnotetext{
15 Beresnevičius (2003a), p. 17.

16 Beresnevičius (2003a), p. 21, 67f.,

17 Beresnevičius (2003a), p 31, 55, 68,

18 Beresnevičius (2003a), p.31.
} 
of "new Europe"19 led by Lithuania, is to help to make this autumn a "calm golden autumn" 20 , providing (in the alliance with the US) "the perimeter of security"21 for a hundred years or more.

Perhaps for the first time during a very long time we are on the side of the powerful, becoming part of the largest power concentration. This is a historical chance which we have to use; it looks like in Star Wars: the Force is with you. I am not speaking tongue-in-cheek here. If the world is twosided, it is not bad to be on the proper side and to join it at the right time. ${ }^{22}$

Beresnevičius even plays with the idea of the imminent rise (or rather restoration) of Lithuanian civilisation, discussing in detail its central symbols - the Rüpintojèlis (Pensive Christ) and the Vytis, an armour-clad knight on the back of a white horse, holding sword and shield. The Vytis (part of the the Lithuanian coat of arms) stands for Lithuania as empire, originally representing a pagan war god. Rüpintojèlis is the most popular figure in the Lithuanian religious folk woodwork. According to Beresnevičius, it stands for the promise of the original Lithuanian civilisation to solve the ecological problems of the modern world. This civilisation will be based on the use of renewable resources (wood, water, earth instead of stone, metal, oil), on the spoken word and on meditation.

In the Footsteps of the Grand Duchy: Lithuania's Eastern Foreign Policy after the Accession to the EU and NATO

Beresnevičius' dream of the creation or restoration of the Lithuanian civilisation may appeal only to a handful supporters of the neo-pagan movement Romuva, a religious New Age movement reviving the ancient religious practices of the Baltic tribes before their christianisation. ${ }^{23}$ However, his ideas about Lithuania's membership of the EU and NATO as the chance for 'making empire' in the former territories of the GDL were embraced by an informal group of entrepreneurs, media moguls and high-ranking state officials of Lithuania known as valstybininkai (statesmen) among political observers. ${ }^{24}$ They

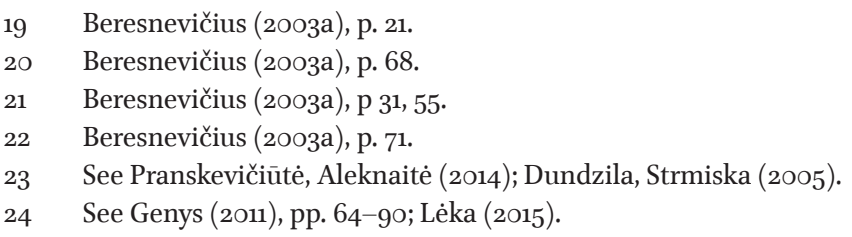


were the driving force behind the removal of President Rolandas Paksas by impeachment in 2003-2004 after his unexpected victory against American Lithuanian Valdas Adamkus, who served his first term as President in 19982003 and did run for second term in 2003. ${ }^{25}$ Ousting Paksas, they remained in firm control of Lithuania's internal and foreign policy during the short period under acting President Artūras Paulauskas in April-July 2004 and during the second term of Adamkus in 2004-2009, who was re-elected after all in the new election following the removal of Paksas.

Among the valstybininkai, the two most influential figures were Raimundas Lopata (born 1965), who from 1998 to 2009 served as the director of the prestigious Institute of International Relations and Political Science at Vilnius University, and Albinas Januška (born 196o), described as the 'grey eminence' of Lithuanian politics in the confidential reports of Western diplomats in Vilnius, published by Wikileaks. ${ }^{26}$ Between 1993 and 2008 he served in various top positions in the Ministry of Foreign Affairs of Lithuania and became chief advisor for Adamkus. Together with another influential member of the valstybininkai group, Mečys Laurinkus, who was the Head of the Lithuanian secret service, he masterminded the removal of Paksas via impeachment. At the same time, the Institute of International Relations and Political Science under Lopata established itself as the main 'think tank' for the Lithuanian government.

Arguably, Januška and Lopata were the most influential makers of Lithuanian foreign policy from 2004 to 2009 , forging the doctrine of Lithuania as the "regional centre" or "regional power". ${ }^{27}$ In May 200o, during the meeting of the ministers of foreign affairs of Albania, Bulgaria, Croatia, Estonia, Latvia, Lithuania, Macedonia, Romania, Slovakia and Slovenia a group of countries applying for membership in NATO was established. After it was joined by Croatia, it was called "Vilnius 10" group. At this time, Lithuanian politicians felt that theirs was a very important country. They were eager to make permanent their self-assumed and self-perceived role as leader of the New (post-Communist) West - even if there were few (if any) neighbouring countries which recognised Lithuania in such a role. This aim was proclaimed by the acting President Paulauskas in 2004, ${ }^{28}$ and then reasserted on numerous occasions by Adamkus:

\footnotetext{
25 See Norkus (2012), pp. 296-324.

26 See Lèka (2015).

27 For surveys of Lithuania's foreign policy after accession to the EU see Baubinaite (2011); Jonavičius (2006); Kojala, Ivanauskas (2014); Lopata, Statkus (2005); Paulauskas (2005); Statkus, Paulauskas et al. (2006).

28 See Paulauskas (2004).
} 
Lithuania can and must be a centre of regional gravity. That should be our strategic orientation. This is ambitious, but we have historic, geographic and political preconditions to succeed. [...] I see Vilnius as a natural centre of the region, where political initiatives are being born and implemented. ${ }^{29}$

The authors of this doctrine hoped to compensate for Lithuania's rather modest resources by the country's special relations with the United States, profiling it as the most trustworthy state in the new Europe, deserving the role of the leading operator of US resources in the promotion of democracy in the former republics of the USSR. For this role, Lithuania's status as a former Soviet republic would not be a liability but an asset, providing first-hand knowledge of local conditions and the trust of local elites thanks to a common past and similar cultural background. The country's small size and apparent weakness would make its activities less conspicuous and suspicious both for opponents of the Western infiltration in these countries and for sceptics about the eastward enlargement of NATO and the EU in Western European countries.

Actually, there were two other former Soviet republics which became part of the "new Europe" in 2004: Estonia and Latvia. However, according to the assessment by Lithuania's valstybininkai, it had a crucial competitive advantage in the rivalry for the role of top operator and coordinator of the eastward promotion of democracy: the legacy of the GDL, which provided a special relationship with Belarus and Ukraine, the most important targets for the promotion of democracy. ${ }^{30}$ The Lithuanian elites were strengthened in their belief in the importance of shared memories of the Grand Duchy by the events of the Orange Revolution in Ukraine. Between November 2004 and January 2005, the Orange Revolution was staged by supporters of the pro-Western presidential candidate Viktor Yushchenko, who refused to recognize his defeat, claiming that the vote was rigged. Together with Poland's President Aleksander Kwaśniewski, Adamkus was invited to mediate, playing an important role in persuading Yushchenko's opponent Viktor Yanukovich to yield and to accept a repeat of the run-off vote, which brought victory to Yushchenko.

Soon Lopata could be delighted to see that Adamkus was so fascinated with the claimed role of Lithuania as regional power that he "started to identify himself with former rulers of Lithuania as their direct heir". ${ }^{31}$ During the 2009 millennial celebration of the first recorded mention of the name of Lithuania,

29 Adamkus (2004b). See also Adamkus (2004a); Adamkus (2005).

30 See Paulauskas (2005).

$31 \quad$ Jokubaitis, Lopata (2014), p. 272. 
which was attended by the heads of neighbouring states, he proclaimed: "Now, surrounded by honourable guests, I feel the same feelings, which were felt by the rulers of Lithuania in those times". ${ }^{32}$ After visiting Lutsk, which is now a Ukrainian city, Adamkus made the following entry into his diary: "This is the city of the Grand Duchy of Lithuania, here is the castle built by Liubartas, son of Gediminas, resembling Trakai castle. According to historian Alfredas Bumblauskas, I was the second ruler of Lithuania after Vytautas who visited the castle."33

Following the suggestion of Beresnevičius, the architects of Lithuania's foreign policy extended the interest sphere of the would-be regional power Lithuania far beyond the borders of the Grand Duchy. In Grand Duke Vytautas's time, the GDL reached to the Black Sea. Claiming the role of regional power for contemporary Lithuania, its government extended its zone of responsibility for spreading the values of Western civilisation to Transcaucasia, acting as one of the most vociferous advocates of Georgia, which after the Rose Revolution in Georgia in 2003 made the bid to become a member of the EU and NAто. Adamkus visited Armenia and Azerbaijan, airing Lithuania's readiness to participate in the resolution of the conflict between both countries. ${ }^{34}$

Discussing the long-term aims of small Lithuania's bid to become a regional power in Eastern Europe, Lithuanian experts refer to the prospect of finally achieving security from Russia once Lithuania will be surrounded from all sides by member states of the EU and NATO, whose new pro-Western elites will be attached to Lithuania by the ties of gratitude to Lithuania for its co-sponsorship. ${ }^{35}$ They seldom forget to add that Lithuania's bid for the role as a regional power is no threat to Russia, because the only Lithuanian interest regarding Russia is to make it safe for democracy. Do then Lithuanian politicians mean that there is no ultimate security until the democratisation of Russia?

In fact, besides this manifest agenda about Russia there may also be a hidden agenda. This agenda is grounded in the widespread persuasion in Lithuania that contemporary Russia cannot become a democratic country because it remains an empire. Any real democratisation in Russia would trigger empire-destroying centrifugal tendencies among the political forces in Russia's regions that also seek autonomy and independence. Importantly, such forces can be expected to emerge not only in its 'autonomous republics' (where

32 Cited according to Jokubaitis, Lopata (2014), p. 272.

33 Adamkus (2011), p. 312.

34 See Kojala, Ivanauskas (2014).

35 See Jonavičius (2006); Statkus, Paulauskas (2006); Baubinaitė (2011); Kasčiūnas, Kojala (2013). 
they are already present), but also in the Russian core regions. This is the main lesson which was learned by the Lithuanian political elites from Russia's two failures at democratisation in 1917 and 1991-1998.

The puzzling fact about the political geography of contemporary Lithuania is that it borders Russia not in the East, where its neighbour is Belarus, but in the West, where the Kaliningrad oblast is located, populated by nearly one million people and covering 15.100 square kilometres. Kaliningrad oblast is the part of Eastern Prussia given to the Soviet Union after the Second World War. Joseph Stalin may have toyed with the idea to merge the Soviet part of East Prussia with Soviet Lithuania, but then made it an oblast of the Russian Federation. ${ }^{36}$ Meanwhile, contemporary Lithuanians still designate these lands by the historical name of as 'Minor Lithuania', distinguishing it from 'Major Lithuania, the ethnically Lithuanian lands which were part of the GDL and then of the Russian empire. The first book in Lithuanian was printed in Königsberg in 1547, and Minor Lithuania is the place where Kristijonas Donelaitis (1714-1780) lived and worked, revered as the author of the first classic Lithuanian language poem Metai (The Seasons). Therefore Lithuanian nationalists consider the Kaliningrad oblast as part of 'historical Lithuania', suggesting that Lithuania has special rights and responsibilities for this territory. ${ }^{37}$

After the dissolution of the UssR, the Kaliningrad oblast became a distant exclave of Russia. Its high level of militarisation only increased in the postSoviet era, when many Russian military units, formerly located in the Baltic countries, were relocated to the Kalingrad oblast. Russia's demand of military transit rights was one of the most difficult issues in the Lithuanian-Russian relations since the restoration of Lithuanian independence. When Poland and Lithuania tightened the control of their borders before joining the Schengen Area, this created additional new difficulties for Russians in Kaliningrad who wanted to enter the Russian mainland. The issue of Russian military transit through Lithuania was internationalised after Lithuania's accession to NATO and the EU. It was resolved in the negotiations between Russia and the US, fostering the feeling of Lithuanian political elites of the political importance and mission of its country on the world stage.

However, many political thinkers in Lithuania, including Lopata, whose area of expertise is Kaliningrad Studies, ${ }^{38}$ consider the oblast's present status merely temporary, expecting a final resolution of the 'Kaliningrad puzzle' from the pending disintegration of Russia in the wake of its next democratic

$36 \quad$ See Safronovas (2016).

37 See Landsbergis (2003) for the most authoritative statement. See also Safronovas (2016).

38 See Lopata (2006). 
revolution. Along with democratisation, this final solution will include its demilitarisation and 'decolonisation', meaning the separation of the Kaliningrad oblast from Russia and becoming the fourth Baltic State (and another member of the EU and NATO) along with Estonia, Latvia and Lithuania. The emergence of this new state will provide a special bonus for Lithuania, because this new Baltic state is expected to gravitate to small and inoffensive Lithuania rather than to Poland and Germany, the other interested parties.

\section{$5 \quad$ Conclusion: Fruits and Predicaments of the Lithuanian 'Restoration' of the GDL}

In 2013, Lithuania used its Presidency of the Council of the European Union in 2013 as the long awaited opportunity to play the role of regional centre. One of its tasks in this role was to coordinate the completion of the negotiation process for the signing of the association agreement between Ukraine and the EU. A wave of protests called the "Euromaidan" movement was sparked by Ukraine's President Yanukovich's last minute refusal to sign this agreement at the 28-29 November 2013 EU summit in Vilnius. Thus the ongoing Ukrainian crisis started, including the violent removal of President Victor Yanukovych, the annexation of Crimea by Russia, the civil violence in Eastern Ukraine, escalating into the Russian-Ukrainian hybrid war, and the exchange of sanctions and countersanctions between the EU and Russia. Lithuania's role in this crisis remained very prominent, even after the end of its Presidency in 2014.

However, this activity peaked during the critical months until the final showdown in late February 2014. Between December 2013 and February 2014 all important Lithuanian politicians visited Kyiv, making speeches to encourage Euromaidan protesters and pressuring Ukrainian officials not to crack down on the increasingly violent demonstrators. Since Yanukovich's removal by force, Lithuania remains among the most enthusiastic supporters of the new 'pro-European' government, pleading for new sanctions against Russia and the arming of Ukraine's military with modern Western weapons, enabling it to win a military victory against the Donbass separatists and the Russian army.

A more detailed assessment of the Lithuanian contribution to the victory of the opposition is not possible without access to confidential information, which will be open only to future historians. The Lithuanian government firmly denies the allegations of the Russian mass media that Lithuanian's secret service helped train the Ukrainian activists whose violent actions played a crucial role in breaking the resistance of government forces. These allegations may be false, but the credibility of Lithuanian denials is somewhat undermined by the 
continuing refusal to admit that Lithuania (as well as Poland and Romania) from 2004 to 2006 hosted a secret US Central Intelligence Agency (CIA) prison, where terrorist suspects were detained and interrogated. The existence of such prisons has been admitted by former top officials of other suspected countries. ${ }^{39}$

While the Maidan victory was a success of Lithuania's 'neo-imperial' foreign policy, it was not an unambiguous success. Its side-effect was decreased security for Lithuania because of increased exposure to the subsequent Russian military build-up. During the last two years, Lithuania nearly doubled its military spending and re-introduced universal compulsory military service. A central topic of the Lithuanian media is the "Russian danger" and a possibly imminent military attack. The future might harbour new embarrassments, which are the topic of our concluding considerations, focusing on the contested imperial legacy of the GDL. ${ }^{40}$ One of them is related to Lithuanian-Belarusian relations.

While Lithuanian historians tell the history of the Grand Duchy as that of the predecessor of the modern Lithuanian nation state, Russian historiography describes the Grand Duchy as a Western Russian state. According to the most widespread Polish view, the Grand Duchy was at least since the late fourteenth century a part of Poland's history as an episode of its (uniquely peaceful) eastward expansion. ${ }^{41}$ The historiography of the newly independent state of Belarus is the latest participant in this contention.

Some Belarusian historians argue that the Grand Duchy was an ancient Belarusian state. According to the most radical version of this view the core of the GDL was an area called Black Rus' with its centre in Novahrudak. The region's nobility hired Baltic mercenaries to conquer neighbouring Slavonic and Baltic lands. ${ }^{42} \mathrm{~A}$ less radical version explains the emergence of the GDL in terms of a "political alliance", ${ }^{43}$ or a "symbiosis" of both ethnic groups. ${ }^{44}$ Both versions refer to the use of the Slavic language, interpreted as "old Belarusian", in the chancelery of the GDL, and claim that even if the rulers of the GDL were of non-Slavic origin, they were early and easily slavified. ${ }^{45}$ The only land to have escaped the intensified assimilation of Balts following the Belarusian conquest was Samogitia (Lower Lithuania) - the true predecessor of contemporary

\footnotetext{
39 See e.g. Open Society Foundations (2013).

40 See also Lopata, Vinogradnaitė (2016); Nikžentaitis (2016).

41 See Halecki (1919-1920); Kolankowski (1930).

42 See Ermalovič ([1989] 1991); ([1990] 2003); ([2000] 2003).

43 Kraŭcèvič ([1998] 200o), p. 141.

44 Nasevič (1993), p. 6o; Saganovič (2001), p. 71f.

45 See e.g. Saganovič (2001), p. 76.
} 
Lithuania. To avoid confusion between contemporary Lithuanians and the early Grand Duchy's metropolitan nation, which today call themselves "Belarusians" and were called Lithuanians in the Middle Ages, Belarussian historians propose that they go by different names: the latter should be called "Litvin" (литвин), the former "Lietuvis" (летувис). ${ }^{46}$

While the authoritarian regime of Alexander Lukashenko is currently suppressing nationalist zeal, one of the side-effects of a possible future democratisation of Belarus may well be a name-change for Lithuania (to "Litva") and its inhabitants (to "Litvins"). This may well spark a dispute similar to the one between Greece and the former Yugoslav republic of Macedonia ('Northern Macedonia') over its correct naming, an issue that caused a deadlock to Macedonia's accession to the NATO and EU for so long. Additionally, the coming conflict over which country is 'the true Lithuania' also implies the resurrection of the "Vilnius question", which poisoned Polish-Lithuanian relations during the interwar period. The famous British historian Norman Davies accepted the Belarusian view of the Grand Duchy's history, expounding it in his bestseller Vanished Kingdoms. ${ }^{47}$ Davies was furiously denounced by Lithuania-based authors as a result. ${ }^{48}$

Another potential embarrassment involves Polish-Lithuanian relations. How can the breath-taking programme of the restoration of the GDL or making Lithuania a "regional centre" be harmonised with similar aspirations of Poland? Nearly all monuments of Western European architecture in the territory of contemporary Belarus and Ukraine, claimed as vestiges of a 'Greater Lithuania' in carefully documented, richly illustrated and widely sold books, ${ }^{49}$ can be - and are - also claimed by Polish patriots as monuments of 'Greater Poland'. Importantly, the Polish legacy in the former PLC is represented in Belarus, Lithuania and Ukraine by large, well organised and politically active Polish minorities, which work to preserve this legacy and foster the relations with the homeland. Differently from Poland, contemporary Lithuania has no such powerful agency to assert its influence in the former GDL lands.

There are influential political forces in contemporary Poland pleading for the resuscitation of Józef Piłsudski's interwar political project of Intermarium (Międzymorze) - a Poland-led federation, including not only new states on the territory of the former PLC, but also nearly all countries of post-communist

46 See Kraŭcèvič (2003). For the response of Lithuanian historians see Bumblauskas (2008).

47 See Davies (2012), pp. 229-308.

48 Baronas, Rowell (2015), p. 77.

49 See Bumblauskas (2005); Valionytė (2009); Valionytė (2009-2012). 
"new Europe". ${ }^{50}$ There is no clarity about its relationship to the existing EU. After the further eastern expansion of the EU, including not only Ukraine, but also Belarus, Intermarium may act as the bloc of nearly all new Eastern EU members, united not only against the resurrection of Russian imperialism, but also against German hegemony in the EU. However, it may also be conceived as an alternative to the EU, especially for the emergency case of its dissolution.

In Lithuania, $6.6 \%$ of its total population identify as Polish. This group is politically represented by the Electoral Action of Poles in Lithuania - Christian Families Alliance (EAPL-CFA), which won 8 seats (from a total of 141) in the election of the Lithuanian parliament in October 2016. Lithuania may aspire to play the role of regional centre, but the inadequacy of its real resources for this aim is displayed every time when it is censured by Poland's government for violations of Polish minority rights. Although the situation of the Polish minority in Lithuania is demonstrably the best among all former Commonwealth lands, ${ }^{51}$ varying Polish political forces harshly criticise Lithuania for what they perceive as infraction of the Polish minority rights by Lithuanian government. ${ }^{52}$

National identities and stereotypes continue in force in the enlarging European Union, influencing the foreign policy of its new members such as Luthuania, the case analysed here. The analysis demonstrates that accession to the EU or NATO does neither end independent foreign policy-making nor liberates it from the influence of nationalist myths and legacies. Quite the opposite: $\mathrm{EU}$ membership may be used by national political elites as a source of opportunities in the pursuit of their particular (and sometimes murky) agendas.

\section{Bibliography}

Adamkus, Valdas (2004a). 'Lithuania as a Centre of Regional Cooperation', Lithuanian Foreign Policy Review, 13-14, pp. 17-20.

Adamkus, Valdas (2004b). Respublikos Prezidento Valdo Adamkaus kalba Lietuvos diplomatinių misijų vadovams, 13.07.2004. Address by H. E. Mr. Valdas Adamkus, President of the Republic of Lithuania, during the meeting of the heads of foreign diplomatic missions in Lithuania. http://archyvas.lrp.lt/lt/news.full/5121 [accessed 27.04.2019].

$50 \quad$ See e.g. Chodakiewicz (2012); Łukasiewicz (2010).

$5^{1} \quad$ See e.g. Motuzas (2001).

$5^{2} \quad$ See Tracevskis (2016). 
Adamkus, Valdas (2005). 'Black Sea Vision', Lithuanian Foreign Policy Review, 15-16, pp. 7-11.

Adamkus, Valdas (2011). Paskutine kadencija. Prezidento dienoraščiai (Vilnius: Tyto alba).

Baronas, Darius, Artūras Dubonis, Rimvydas Petrauskas (2011). XIII a. - 1385 m. Valstybès iškilimas tarp Rytu ir Vakaru. Lietuvos istorija, t. 3 (Vilnius: Baltos lankos).

Baronas, Darius, Stephen C. Rowell (2015). The Conversion of Lithuania. From Pagan Barbarians to Late Medieval Christians (Vilnius: The Institute of Lithuanian Literature and Folklore).

Baubinaite, Kristina (2011). 'The Preconditions of the Grand Strategy in Lithuania', Lithuanian Foreign Policy Review, 26, pp. 54-83.

Beresnevičius, Gintaras (1990). Dausos. Pomirtinio gyvenimo samprata senojoje lietuviu pasaulèžiūroje (Klaipèda: Gimtinè).

Beresnevičius, Gintaras (1995). Baltų religinès reformos (Vilnius: Taura).

Beresnevičius, Gintaras (1998). Kosmosas ir šventvietès lietuviu ir prūsu religijose (Kaunas: vdu leidykla).

Beresnevičius, Gintaras (2002). Ant laiko ašmenų (Vilnius: Aidai).

Beresnevičius, Gintaras (2003a). Imperijos darymas. Lietuviškos ideologijos metmenys. Europos Sajunga ir Lietuvos geopolitika XXI a. pirmojoje pusejje (Vilnius: Vilniaus universitetas, Tarptautinių santykių ir politikos mokslų institutas).

Beresnevičius, Gintaras (2003b). Palemono mazgas. Palemono legendos periferinis turinys. Religinè istorinè studija (Vilnius: Sapnų sala).

Beresnevičius, Gintaras (2004). Lietuviu religija ir mitologija. Sisteminè studija (Vilnius: Tyto alba).

Bumblauskas, Alfredas (2005). Senosios Lietuvos istorija 1009-1795 (Vilnius: R. Paknio leidykla).

Bumblauskas, Alfredas (2008). 'LDK paveldo dalybos ir "Litva-Letuva" distinkcijos konceptas', in Alfreda Bumblauskas, Šarūnas Liekis, Grigorijus Potašenko (eds), Lietuvos Didžiosios Kunigaikštijos tradicija ir paveldo 'dalybos'(Vilnius: vu leidykla), pp. $15^{-66 .}$

Chodakiewicz, Marek Jan (2012). Intermarium. The Land between the Black and Baltic Seas (New Brunswick, NJ: Transaction Publishers).

Davies, Norman (2012). Vanished Kingdoms. The Rise and Fall of States and Nations (New York: Penguin Books).

Dundzila, Vilius Rudra, Michael Strmiska (2005). 'Romuva. Lithuanian Paganism in Lithuania and America' in Michael F. Strmiska (ed.) Modern Paganism in World Cultures. Comparative Perspectives (Santa Barbara: ABC-CLIO), pp. 241-298.

Eder, Klaus (2009). 'A Theory of Collective Identity. Making Sense of the Debate on a European Identity', European Journal of Social Theory, 12.4, pp. 427-447.

Ermalovič, Mikola I. ([1989] 1991). Pa sljadax adnago mifa (Minsk: Navuka I tėxnika). 
Ermalovič, Mikola I. ([1990] 2003). Staražytnaja Belarus'. polacki i novagarodski peryjady. 2-e vyd. (Minsk: Mastackaja litaratura).

Ermalovič, Mikola I. ([2000] 2003). Belaruskaja dzjaržava Vjalikae Knjastva Litoŭskae (Minsk: Bellitfond).

Gedgaudas, Česlovas (1972). Mūsu praeities beieškant (Mexico: Č. Gedgaudas).

Genys, Dainius (2011). Lietuvos pilietinès visuomenès ribos ir konfliktai dèl jų. Doctoral dissertation (Kaunas: Vytautas Magnus University).

Gudavičius, Edvardas (1999). Lietuvos istorija nuo seniausių laiku iki 1569 metu (Vilnius: Lietuvos rašytojų s-gos leidykla).

Halecki, Oskar (1919-1920). Dzieje Unii Jagiellońskiej. T. 1-2 (Krakow: Akad. Umiejętności Fundusz N. Bucewicza).

Hroch, Miroslav (1985). Social Preconditions of National Revival in Europe. A Comparative Analysis of the Social Composition of Patriotic Groups among the Smaller European Nations (Cambridge: Cambridge University Press).

Jokubaitis, Alvydas, Raimundas Lopata (2014). Lietuva kaip problema. Filosofiniai istoriniai politikos tyrinejjimai (Vilnius: Tyto alba).

Jonavičius, Laurynas (2006). 'Geopolitical Projections of New Lithuanian Foreign Policy', Lithuanian Foreign Policy Review, 17, pp.15-40.

Kasčiūnas, Laurynas, Linas Kojala (2013). 'EU Policy towards Russia. Will We Fill the Strategic Vacuum?', Lithuanian Foreign Policy Review, 30, pp. 133-142.

Kiaupa, Zigmantas, Jūratė Kiaupienė, Albinas Kuncevičius (2000). The History of Lithuania before 1795 (Vilnius: Lithuanian Institute of History).

Kiaupienė, Jūratė, Rimvydas Petrauskas (2009). Nauji horizontai. Dinastija, visuomenè, valstybè. Lietuvos Didžioji Kunigaikštystè 1386-1529 m. Lietuvos istorija, t. 4. (Vilnius: Baltos lankos).

Kolankowski, Ludwik (1936). Polska Jagiellonów. Dzieje polityczne (Lwów: Skład głowny w Księgarni Gubrynowicz i syn).

Kraŭcėvič, Aljaksandr ([1998] 200o). Stvarènne Vjalikaga Knjastva Litoŭskaga (Rzeszów: Uniwersytet Marii Curie-Skłodowskiej w Lublinie).

Kraŭcèvič, Aljaksandr (2003). 'Terminy Litva i Letuva u sučasnaj belauskaj gistaryjagrafii', Gistaryčny al'manakh 9, pp. 104-107.

Kojala, Linas, Vilius Ivanauskas (2014). 'Lithuanian Eastern Policy 2004-2014. The Role Theory Approach', Lithuanian Foreign Policy Review, 32, pp. 49-72.

Landsbergis, Vytautas (2003). Karaliaučius ir Lietuva. Nuostatos ir idejos (Vilnius: Demokratinès politikos institutas).

Lèka, Aušra. (2015). 'Lietuvos (už)valdymas: režisieriai, prodiuseriai, aktoriai', Veidas tag archive. http://www.veidas.lt/tag/albinas-januska [accessed 27.04.2019].

Lopata, Raimundas (2006). Anatomy of a Hostage. Kaliningrad Anniversary Case (Tartu: Baltic Defence College). 
Lopata, Raimundas (2010). Politikai ir istorija. Algirdo Brazausko ir Vytauto Landsbergio istorijos sampratos (Vilnius: vu leidykla).

Lopata, Raimundas, Nortautas Statkus (2005). 'Empires, the World Order and Small States', Lithuanian Foreign Policy Review, 15-16, pp. 16-5o.

Lopata, Raimundas Inga Vinogradnaitė (2016). Lietuvos ir Baltarusijos istorijos politika (Vilnius: vu leidykla).

Łukasiewicz, Sławomir (2010). Trzecia Europa. Polska myśl federalistyczna w Stanach Zjednoczonych, 1940-1971 (Warsaw: Institute for National Remembrance).

Motuzas, Remigijus (2001). 'Education of National Minorities in Lithuania', Lithuanian Foreign Policy Review, 7, pp. 1-12.

Nasevič, Vjačaslaŭ L. (1993). Pačatki Vjalikaga knjastva Litoŭskaga. Padzei i asoby. (Minsk: Polymja).

Norkus, Zenonas (2012). On Baltic Slovenia and Adriatic Lithuania. A Qualitative Comparative Analysis of Patterns in Post-Communist Transformation (Budapest: CEU Press).

Norkus, Zenonas (2018). An Unproclaimed Empire. The Grand Duchy of Lithuania From the Viewpoint of Comparative Historical Sociology of Empires (Abingdon: Routledge).

Open Society Foundations (2013). 'Lithuania's Silence on CIA Abuses Faces European Court Challenge'. https://www.opensocietyfoundations.org/press-releases/ lithuanias-silence-cia-abuses-faces-european-court-challenge [accessed 27.04.2019].

Paulauskas, Kęstutis (2005). 'The Baltic States. Picking Regions, Shedding Myths, Decoding Acronyms', Lithuanian Foreign Policy Review, 15-16, pp. 51-64.

Pranskevičiūtė Rasa, Eglè Aleknaitė (2014). ‘Šiuolaikinė pagonybė Lietuvoje. Matomos ir nematomos grupès', in Milda Ališauskienè (ed.) Religijų ivvairove Lietuvoje: portretai, kasdienybe ir šventès (Vilnius: Versus aureus), pp. 170-173.

Rowell, Stephen C. (1994). Lithuania Ascending. A Pagan Empire Within East-Central Europe, 1295-1345 (Cambridge: Cambridge University Press).

Nikžentaitis, Alvydas (2016). 'Abiejų Tautų Respublikos ir Lietuvos Didžiosios Kunigaikštystės praeitis lietuvių, lenkų, baltarusių ir ukrainiečių atminties kultūroje po 1990 metư', Lietuvos istorijos metraštis, 1, pp. 49-70.

Paulauskas, Artūras (2004). 'Lithuania's New Foreign Policy', Lithuanian Foreign Policy Review, 13-14, pp. 7-16.

Safronovas, Vasilijus (2016). The Creation of National Spaces in a Pluricultural Region. The Case of Prussian Lithuania (Boston: Academic Studies Press).

Saganovič, Genadz' (2001). Narys gistoryi Belarusi ad staražytnasci da kanca XVIII stagoddzja. (Minsk: Encyklapedyks).

Statkus, Nortautas, Kęstutis Paulauskas (2006). 'Foreign Policy of Lithuania. Linking Theory to Practice', Lithuanian Foreign Policy Review, 17, pp.41-82.

Statkutė de Rosales, Jūratė (2004). Balts and Goths. The Missing Link in European History. (Lemont [Ill.]: Vydūnas Youth Fund). 
Tracevskis, Rokas (2016). 'Lietuva savo suvereniteto Lenkijai perduoti neprivalo', o7.12.2016. http://www.delfi.lt/news/ringas/lit/r-tracevskis-lietuva-savo-suvereniteto-lenkijaiperduoti-neprivalo.d?id=72984206 [accessed 27.04.2019].

Valionis, Antanas (2006). 'Lithuania's New Foreign Policy Agenda', Lithuanian Foreign Policy Review, 17, pp. 6-14.

Valionytė, Birutė (2009). Reikšmingas LDK paveldas Baltarusijoje / Significant Heritage of the Grand Duchy of Lithuania in Belarus (Vilnius: Artlora).

Valionytė, Birutė (2009-2012). Didžioji Lietuva. Vol. 1-3 (Vilnius: Artlora). 


\title{
The Longue durée of Brexit
}

\author{
Politics, Literature and the British Past
}

\author{
Daniel Carey
}

\begin{abstract}
The complex proposition posed by Brexit challenges us to reinvestigate British reflections on identity from an historical point of view. This contribution considers a range of precedents, beginning with the English Reformation before considering questions of sovereignty, separation, immigration and exceptionalism in the seventeenth and eighteenth centuries. The claim is not that history straightforwardly facilitates an understanding of the fissures associated with Brexit, but rather that the present is ironised as much as it is explained by the past. We have much to learn not just from history but from works of poetry, fiction and drama that engage with historical concerns of identity and politics. The contribution looks first at Defoe's poem The True-Born Englishman (1701) and aspects of Robinson Crusoe (1719), with their mixed-conceptions of identity, followed by attention to Shakespeare's Richard II, Henry $v$, and the plot twists of Cymbeline, a romance predicated on separation from Roman authority. The contribution concludes with Churchill and the contradictions in British attitudes to Europe inherited by Theresa May and Boris Johnson, which promise to endure as the UK redefines its relationship to Ireland and Continental Europe.
\end{abstract}

The outcome of the UK referendum on whether to leave or remain in the European Union has dominated politics in parliament and the country since the result of the vote was announced on the morning of the 24th of June 2016 . The narrow margin of victory for the leave campaign (51.9\%), the fact that two of the four constituent parts of the UK voted by majority to remain (Scotland and Northern Ireland), the overwhelming desire to stay in the EU registered across London (the dominant base of the population and economic centre of power) have ensured that the deep divisions apparent in the campaign have not disappeared. Indeed they are set to continue, not least because it is unclear what exactly people intended to vote for (contradicting Theresa May's slogan 'Brexit means Brexit'), and whether political will can be permanently vested in such a transitory act. The resulting free-for-all of interpretation and struggles over a second referendum or 'people's vote' on the outcome of negotiations

(C) DANIEL CAREY, 2021 | DOI:10.1163/9789004436107_005

This is an open access chapter distributed under the terms of the CC BY-NC-ND 4.0 license. 
testify to this confused scenario. The stakes are so high because the vote did not, as in a general election, establish a government of a certain duration, but undid an entire set of longstanding relationships, while provoking anxious and unresolved issues of identity that will continue to confront the country for a generation or more.

The question that Brexit poses is at one level political but it remains, ultimately, a conflict over identity. The identity problem in this context has two related strands - the internal dimension of how the future will play out for the component parts that make up an ostensibly United Kingdom, and the external dimension as the UK negotiates a future alongside but no longer within the EU. The two dilemmas converge, of course, on the island of Ireland, where the shared border provides the key point of contact. But the larger confrontation is with the UK's image of itself: is the narrative one of weakness or strength, reasserted sovereignty or isolation in an interconnected world?

This bewildering predicament has inevitably prompted a search for some perspective on these developments. This essay attempts to chart a longue durée of Brexit by considering historical precedent, returning initially to the English Reformation and religious difference before considering questions of sovereignty and the composition of the nation. The claim is not that the fissures associated with Brexit lend themselves to ready interpretation by mere recourse to history, but rather that the present is ironised as much as it is explained by the past. The search for analogy is therefore inspired by an attempt to gain perspective, not in order to simplify the current cataclysm or claim that it could have been readily predicted. We have much to learn not just from history but from works of poetry, fiction and drama of the same period that engage with historical concerns of identity and political form. Here I consider various texts by Shakespeare and Defoe, which provide us with a crucial resource since they remain attuned, above all, to historical contradictions.The urgency associated with Brexit has given fresh relevance to inquiries into the emergence of concepts of Britain and Britishness. ${ }^{1}$ Historians concerned with this matter have explored the conditions of state formation, asking where and when did a sense of national identity (and destiny) arise. Or was it merely a fiction imposed on a complex cultural topography, driven by political interests? Attempts have been made to wrest the narrative away from an English-centric

1 Fintan O'Toole maintains that "Brexit is essentially an English phenomenon" (2018, p. xvi) and accordingly he largely elides Scotland and Wales from his discussion, but a satisfactory account must take into consideration the whole of the UK, not least given the voting patterns which saw substantial numbers support the Leave campaign across the country (if not by a majority in Scotland and Northern Ireland). 
account in favour of greater attention to the archipelago's three kingdoms and the composite monarchy. The periodisation adopted in these analyses varies considerably. Some settle on the sixteenth century and the reign of Henry VIII as a decisive turn; others opt for the union of crowns under James VI and I; and others still emphasise the formal Act of Union in $1707 .{ }^{2}$ My discussion, inevitably selective in the primary sources it responds to, follows this pattern of seeking an early modern orientation on the dilemmas raised by reflection on Brexit. This is perhaps the longest of longues durées. ${ }^{3}$

Arguments in favour of Brexit have a complex genealogy, resonating in different ways with historical antecedents. In terms of epochal developments based on severing a longstanding relationship with extra-national entities, the break with Rome in the context of the English Reformation in the sixteenth century stands out for a number of reasons. ${ }^{4}$ This historical moment represents, under the guise of religious identity, a dispute over sovereignty. Conversely, the proBrexit position leads with sovereignty and the political while being underpinned, in many cases, by nationalist identity politics.

The resonances with the Reformation occur in conjunction with the ways in which the EU has continually been framed in public discourse as an external power branching across the Continent that requires but is resistant to reform. To change it from the inside as part of a process of negotiation remained an option, at least rhetorically, even for a Tory Prime Minister such as David Cameron. But his failure to achieve satisfactory results, along with the political momentum gained by the deeply Euro-sceptic wing of his party - strengthened by the polling success of UKIP and conservative defections - led him to succumb to pressure for a referendum. ${ }^{5}$ For the radical collective in favour of leaving, reform of

2 For accounts that begin in the Tudor period, see Bradshaw, Morrill (1996) and Bradshaw, Roberts (1998); for the era of James VI and I, see Mason (1994) and Kerrigan (2008). Mason (2004) complicates the picture between these two periods, describing Scottish interest in foregrounding an idea of Britain in the Tudor period; for the Act of Union, see Colley (1992) and Robertson (1995). For a study focusing on the early modern formation of English national identity, see Helgerson (1992).

3 See Black (2019) and Heuser (2019) for even earlier points of departure.

4 Cottret (2019) in his book on the Tudors describes this moment as "Un premier Brexit" (pp. 173-189).

5 See Shipman (2017) for a valuable account of the campaign. 
Europe was presented as an impossibility. Only the assertion of national sovereignty could overcome this enduring obstacle and reclaim politics.

The English Reformation represented the beginning of a long process of transformation with serious effects on international relations and the emergence, over time, of a new and distinctive identity. In the present moment, much will depend, inevitably, on the economic and political strength of the EU from which the UK extracts itself, and the capacity of a rechristened United Kingdom to forge alliances (and trading relationships) of its own. The UK will not be withdrawing from NATO any time soon, of course, so the alteredstates scenario has real limitations, whatever it may mean for laws and regulatory frameworks. In this respect it is instructive to consider that although the English Reformation led to the creation of an Established Church, the difference between its rites and those of Rome was minimal. The theology may have been rethought but church service and governance remained relatively unchanged. ${ }^{6}$ We may find in the case of Brexit an ideological transformation which affects very little of life on the ground. In fact, both historical instances of separation constitute assertions of power by a political elite, based on demonising an authority positioned as external. They may require and draw sustenance from popular discontent and widely-held perceptions of intransigence and wastefulness, but they depend on the organised and wellfinanced management from the top. The new regime the UK ends up with will entail a different administrative and legal structure, just as the ecclesiastical apparatus was substituted in the time of Henry viII. But ties with Europe will and must remain strong. The break in that sense will only ever be partial, an illusion as much as a reality.

The second point is perhaps more significant. The English Reformation left a divided country. Catholics - for our purposes we can call them 'remainers' - did not disappear as a voice or constituency, nor was the political nation suddenly eradicated of opponents and the country reassembled in ideological purity and consensus. The retaliation against Protestants by Mary I, who reigned from 1553 to 1558 , reinforced by her marriage to Philip of Spain in 1554, brought the durability of the English Reformation into question, but her short tenure gave way to Elizabeth I and a process of Protestant consolidation (her prospective Habsburg marriage alliances in particular would have complicated the position of course). This is a story of decades of efforts to deal with internal

6 The establishment of a national church engendered a fraught history of dealing with the fallout from Dissenters (and in Scotland with a Presbyterian national church). The pro-Brexit position is no more coherent in that respect and is likely to fragment after an agreement is reached. 
and external Catholic threats. ${ }^{7}$ In the seventeenth century a different struggle occurs in the context of the English Civil War over the form of the state and the role and power of the church, but the Restoration reinvigorated the threat of Catholicism once more. Only with the Glorious Revolution in 1688 is something like an enduring Protestant stamp placed on the country. I suspect that ensuing elections in the UK, leadership contests, and other political struggles will play out similar divides over Europe going forward. Partly this is due to the fact that the UK has no tradition of unity governments, favouring the winnertake-all model. (The recent experience of coalition under the Tories and Liberal Democrats did nothing to persuade the major parties that alliances of this kind were politically helpful, at least to the junior partner.)

The English Reformation was followed by an imperial moment associated with the Welsh Acts of Union of 1535 and 1542 and Henry VIII's assertive rule in Ireland. But control of Ireland was, to put it mildly, imperfect, and proved an ongoing source of difficulty, exacerbated by religious difference (where the Old English and New English parted company over allegiance to Rome or to the Anglican faith). Rebellion in Ireland in the sixteenth, seventeenth, and eighteenth centuries and beyond, was often hinged on (inadequate) support from Continental allies. From this perspective, the assertion of UK sovereignty made in the referendum remains tragically naive about the implications for Ireland, ${ }^{8}$ where the UK governs only the province of Ulster (reinforced by subsequent wrangling over the provision of an Irish backstop agreed in December 2017). The complex position is underscored by treaty commitments under the Good Friday Agreement and the Republic's position as a member state of the EU. Ireland's allies have in this new scenario proved, thus far, more resolute than in the past.

Sovereignty, Separation and Immigration

The desire for regained sovereignty lies at the heart of the Brexit aspiration for many of its supporters. Thus the great refrain has been to 'take back' control of laws and borders. ${ }^{9}$ The prospect of unencumbered legal control is bound up with the wish to gain freedom from the restraint of the European Court of

7 For a classic study, see Dickens (1989); for a revisionist account, see Haigh (1993); for a recent major study Marshall (2017); see also essays on the development of the English Reformation in MacCulloch (2016).

8 On this question, see Connelly (2018).

9 See Heuser (2019). For valuable reflections on sovereignty in the era of globalisation, see Sassen (1996) and (2008). 
Justice and the rule-making role of the European Commission and Parliament. At the same time, the sovereignty argument pays scant attention to the model of power sharing elaborated in regional assemblies and parliaments in the UK, and the whole history of sustained political effort and agitation that brought them into being. Scotland has scarcely figured in the discussion, despite the size of the vote there to remain, largely because its position raises no constitutional questions. The Good Friday Agreement, by contrast, commits the UK and Irish governments to forms of shared sovereignty, a situation made less conspicuous by occupying shared space under the umbrella of the EU. The Scottish government's attempt to insist on involvement in the decision over whether to trigger article 50 was swiftly rejected by the UK Supreme Court in January 2017.

Control of laws is one thing, but control of borders speaks to the desire to limit immigration, nullifying the principle of the free movement of peoples enshrined in the EU's concept of itself and one of the so-called Four Freedoms. This is not to say that other European states have not struggled with this prospect. Different analyses can be provided to explain the impulse in the UK, but a resurgent nativism is clearly part of the story (evident in the campaigning of UKIP for example). The conventional alignment of national identity with ethnicity across Europe (German, French, Spanish, Italian, etc.) deepens the problem. In this respect the UK has an advantage to the extent that the term 'Britain' is more inclusive, encompassing the kingdoms (even if it does not enfranchise Northern Ireland). ${ }^{10}$

The concept of the UK as a separate and sovereign entity, a rule giver not a rule taker, ignores the fact that England has been headed in the past by plenty of 'foreign' monarchs. The House of Hanover is perhaps the best-known example, given George I's reputation for speaking limited English, at least at the outset of his reign. But among foreign sovereigns it is also worth remembering William III (1650-1702), i.e. the Prince of Orange and Dutch Stadholder, victor in the Glorious Revolution. His marriage to James II's Protestant daughter, Mary, provided the basis for his intervention to claim the English crown and the invitation to form a joint monarchy in order to unseat James II. William ruled on his own after Mary's death in 1694, and his 'foreignness' became an object of attack for opponents. The complaints focused on his position on standing armies and his absence in Holland in the summer of 1698, after the

10 The official title of the country is the United Kingdom of Great Britain and Northern Ireland, hence the Democratic Unionist Party's annoyance over the country's branding in Olympic competitions as 'Team GB' (changing this to 'Team UK' was a manifesto pledge of their 2017 general election campaign). 
conclusion of the Nine Years' War, where he executed treaties without parliamentary authority and, a year later, doled out grants to friends for forfeited Irish lands. He was condemned in a verse attack under the title The Foreigners, particularly directed against William's favourites. This work famously provoked an anonymous response from Daniel Defoe in the form of The TrueBorn Englishman (1701).

Defoe's poem, pitched in a satirical vein, complicates the picture of the native and foreign to make a polemical point. ${ }^{11}$ Some of its arguments continue to resonate as a reply to the nativist understanding of 'British' or 'English' identity underpinning a certain strand of Brexit support.

The preface declares that the author is not Dutch, though some might suspect him of being so - rather he is English and he urges his countrymen to "behave themselves better to Strangers, and to Governors also".12 The significance of 1688 might be reinterpreted in this context not so much as the assertion of 'liberty' but rather as the renewed rejection of intrusion by a foreign power in the form of the Catholic Church and the papacy with the support of a Catholic monarch, even a legitimate one. Thus the preface complains that 'pretending' Protestants have in fact "all along endeavour'd to reduce the Liberties and Religion of this Nation into the Hands of King James and his Popish Powers". 13

But the theme for which the poem remains best known is its way of handling the 'identity problem' in contemporary politics. While meditating on English ingratitude towards William, Defoe considers the admixture of peoples that make up the category of the 'English', giving the lie to pronouncements about foreigners. Often invaded, England has found:
While ev'ry Nation that her Pow'rs reduc'd
Their Languages and Manners soon Infus'd.
From whose mixt Relicks our compounded Breed,
Making a Race uncertain and unev'n,
Deriv'd from all the Nations under Heav'n. ${ }^{14}$

He recites the arrival of the Romans with their mixed crew, followed by Jutes, Saxons, Danes, Scots, the Picts, the Irish and then the Normans. They "Blended with Britains, who before were here", resulting in that ultimate hyphenated

\footnotetext{
11 For a recent reading of the poem, see Borsing (2017), ch. 1.

12 [Defoe] (2003), p. 83.

13 [Defoe] (2003), p. 83.

14 [Defoe] (2003), pp. 89f. (ll.169-74).
} 
identity, "Your Roman-Saxon-Danish-Norman English". ${ }^{15}$ The Normans then transformed the country once again. Since that time the pattern has only accelerated:

Dutch, Walloons, Flemings, Irishmen, and Scots,

Vaudois and Valtolins, ${ }^{16}$ and Hugonots,

In good Queen Bess's Charitable Reign,

Suppli'd us with Three hundred thousand Men. ${ }^{17}$

The chronology is a little askew since the Huguenot emigration is a largely seventeenth-century phenomenon in the context of the Revocation of the Edict of Nantes (1685). But the point in general is well-made (although not one that that Nigel Farage has absorbed despite his Huguenot heritage). The important thing is the poem's emphasis on the fact that "from a Mixture of all Kinds began, / That Het'rogeneous Thing, An Englishman":

For Englishmen to boast of Generation,

Cancels their Knowledge, and lampoons the Nation.

A True-Born Englishman's a Contradiction,

In Speech an Irony, in Fact a Fiction. ${ }^{18}$

Defoe's Explanatory Preface to the ninth edition makes clear that he regarded this mixture as a national advantage, not a defect (indeed the Scots, Welsh and Irish suffer from being unmixed in his view). ${ }^{19}$ The poem's argument might be considered specific to a particular political occasion, but there is evidence elsewhere in Defoe's work of his interest in issues of identity and how they play out in a hybrid setting. His 1719 novel, Robinson Crusoe, is worth considering in this context. There is no more English and indeed resolutely Protestant character in the history of fiction than Crusoe (a point that James Joyce remarked on critically). ${ }^{20}$ Yet we are told at the outset of the book that Crusoe's

15 [Defoe] (2003), p. 9o (ll. 185, 194).

16 The Vaudois or Waldenses were a heretical group in Europe, especially Italy; the Valtolins were Protestants residing in Valtellina (Switzerland), who suffered a massacre by Catholics in 1620.

17 [Defoe] (2003), p. 92 (ll. 259-62).

18 [Defoe] (2003), pp. 94, 95 (ll. 334-5, 370-73).

19 [Defoe] (2003), p. 79. For a wider reading of the theme, see Schmidgen (2013).

20 Joyce commented in a lecture in March 1912 in Trieste: "All the Anglo-Saxon soul is in Crusoe: virile independence, unthinking cruelty, persistence, slow yet effective intelligence, sexual apathy, practical and well-balanced religiosity, calculating dourness." Joyce (2000), p. 174. 
father was "a foreigner of Bremen" who settled in Hull. The original surname was Kreutznaer, he tells us, "but by the usual Corruption of Words in England, we are now called, nay, we call our selves, and write our name, Crusoe". ${ }^{21}$ This aspect of the story is reasonably well remembered. On the deserted island, scene of his captivity, Crusoe seems intent above all on replicating an English way of life, rather than going native. In the midst of his isolation he advances in social standing, with a town house and a rural retreat, a bower and other appurtenances of an English lord or member of the gentry. Yet it is only at the end of the book that we learn from him some intriguing details about his time as young man in Brazil, following his escape from captivity in North Africa. There he established a tobacco plantation and - intending to shift to labour-intensive sugar production - he embarked on a mission to Africa to secure slaves. This fateful decision resulted in his shipwreck on the deserted Caribbean island where the main sequence of the novel occurs. After Crusoe's recovery from the island following a residence of twenty-eight years, his fortune is restored to him and he contemplates returning to Brazil, where, he tells us, he had been previously naturalised. What restrains him is his new religious sensibility - a Protestant identity cultivated during his years of isolation through reading the Bible, engaging in prayer and conversation with God, and his later evangelising of Friday. He notes that when he formerly lived in Brazil, he "had made no Scruple of being openly of the Religion of the Country, all the while I was among them". Now, however, Crusoe begins "to regret my having profess'd my self a Papist". ${ }^{22}$ Despite these reservations, he still decides to confer on the Priory of St. Augustine (which, over the course of his long absence, received a substantial portion of the proceeds from his plantation), ${ }^{23}$ a gift of 500 moidores for the monastery and 373 to the poor, "desiring the good Padres Prayers for me". 24

We can, in short, recover an alternative narrative in the most English of sources that suggests a history of hybrid identities, less hostile to the intermixing and integration suggested by the European project and rejected by some Brexit supporters.

\footnotetext{
21 Defoe (2007), p. 5 .

22 Defoe (2007), p. 241.

23 They use this for the "Benefit of the Poor, and for the Conversion of the Indians to the Catholick Faith". The king's third (of Crusoe's half), meanwhile, "was it seems granted away to some other Monastery, or Religious House". Defoe (2007), pp. 235, 236.

24 Defoe (2007), p. 242. It is evident that Crusoe's business partner is Catholic, since Crusoe reports that this individual said many "Ave Marias to thank the Blessed Virgin that I was alive" when he hears from him; Defoe (2007), p. 239.
} 
English or British exceptionalism - the sense that the country has a separate destiny, different from that of Europe - is deeply engrained. The Continent is an 'elsewhere' from which it is physically disconnected but also morally distinct. As Theresa May remarked in her speech in Florence on 22 September 2017: "perhaps because of our history and geography, the European Union never felt to us like an integral part of our national story in the way it does to so many elsewhere in Europe."25 The concept of the "sceptred isle", a place apart with a privileged role and history conferred by geography, derives of course from Shakespeare's Richard II. In his account of the attitudes of leading twentieth-century British political figures to Europe, Hugo Young remarks:

The mythology of the scepter'd isle, the demi-paradise, bit deep into the consciousness of many who addressed the question, beginning with Churchill himself. The sacredness of England, whether or not corrupted into Britain, became a quality setting it, in some minds, for ever apart from Europe. Tampering with this blessed plot was seen for decades as a kind of sacrilege which, even if the sophisticates among the political class could accept it, the people would never tolerate. ${ }^{26}$

The passage in the play is worth looking at with care. As with so many famous speeches in Shakespeare its inherited meaning - that is, the way it is popularly understood - differs from its meaning in context. ${ }^{27}$ Here are the lines:

This royal throne of kings, this sceptred isle,

This earth of majesty, this seat of Mars,

This other Eden, demi-paradise,

This fortress built by nature for herself

Against infection and the hand of war,

This happy breed of men, this little world,

This precious stone set in the silver sea,

Which serves it in the office of a wall,

Or as a moat defensive to a house,

\footnotetext{
25 May (2017). The website with this speech also includes a text of the speech in German.

26 Young (1998), p. 1.

27 For an insightful reading, see Knapp (2002), chapter 3 .
} 
Against the envy of less happier lands,

This blessèd plot, this earth, this realm, this England....28

No one would deny that this is stirring poetry, but who delivers the lines and in what set of circumstances? They come in Act II, scene i, from the Duke of Lancaster, John of Gaunt, ${ }^{29}$ uncle to Richard II and father of Henry Bolingbroke (Duke of Hereford). Henry has shortly before this point been sent into exile by Richard II to avoid a bloody conflict with Thomas Mowbray (Duke of Norfolk), whom the king also banishes. Although Richard shortens Bolingbroke's term of exile on appeal from Gaunt, Gaunt knows he will not live to see his son's return. Indeed the stage directions for the scene in which he delivers the memorable speech read: "Enter John of Gaunt sick". The speech covers $3^{1}$ lines in total, and it begins in prophetic mode, directed against a bad king, foretelling, as Gaunt's death approaches, that Richard cannot continue. In fact Gaunt imagines a country consuming itself, and the speech is really uttered as a lament, providing a narrative of English decline. Soon after the lines quoted above, the speech takes a troubled turn:

This land of such dear souls, this dear, dear land,

Dear for her reputation through the world, Is now leased out - I die pronouncing it Like to a tenement or pelting ${ }^{30}$ farm: England, bound in with the triumphant sea Whose rocky shore beats back the envious siege Of wat'ry Neptune, is now bound in with shame, With inky blots and rotten parchment bonds.

That England that was wont to conquer others Hath made a shameful conquest of itself. Ah, would the scandal vanish with my life, How happy then were my ensuing death! ${ }^{31}$

28 Shakespeare (2016), 2.1. 1l. 40-50.

29 Gaunt's name derives from his birth in Ghent, at St. Bravo's Abbey. His complex Continental ties include the fact that his mother was Philippa of Hainault (his father was Edward III) and he was named for John, duke of Brabant, an ally in the Low Countries of his father. Gaunt's second marriage to the exiled daughter of the murdered Pedro I of Castile gave him a claim to the Castilian crown which he asserted, adopting the royal title of King of Castile and León. See Walker (2004).

30 Worthless, paltry.

$3^{1} \quad$ Shakespeare (2016), 2.1.57-68. 
England has become a tax farm (confirmed in the prior scene, Act 1, scene iv, in fact, by Richard himself). It has lost its freedom, or sovereignty if you like, as a result of legal agreements that have bound it. The country, defensively sealed off by the sea, has paradoxically conquered itself. In short, the sense of England as something glorious is uttered in the midst of the fear of inevitable decline. Something of the recuperative desire among Brexiteers to resume a relationship with the commonwealth after the departure from Europe seems to echo in Gaunt's lament.

Richard II includes the exile of two figures, Bolingbroke and Mowbray, as I mentioned. When Mowbray confronts this prospect, he delivers a rather striking speech about the implications he will confront in terms of language. The way he describes his fate is instructive for a number of reasons:

The language I have learnt these forty years,

My native English, now I must forego,

And now my tongue's use is to me no more

Than an unstringèd viol or a harp,

Or like a cunning instrument cased up,

Or, being open, put into his hands

That knows no touch to tune the harmony.

Within my mouth you have engaoled my tongue,

Doubly portcullised with my teeth and lips,

And dull unfeeling barren ignorance

Is made my gaoler to attend on me.

I am too old to fawn upon a nurse,

Too far in years to be a pupil now.

What is thy sentence then but speechless death,

Which robs my tongue from breathing native breath? ${ }^{32}$

Perhaps one of the hidden stories of Brexit, consistent with the assertion of a 'global Britain, open for business' as the solution to this political maneuver, is about the dominant position of the English language. For a traveller or exile in Shakespeare's time (let alone Richard II's), English was a language that would have done little to facilitate communication on the Continent. Indeed the purpose of travel was precisely to acquire knowledge of foreign tongues, especially French and Italian. If the English language did not now occupy a dominant position, would the outcome of the referendum on EU membership

Shakespeare (2016), 1.3.153-67. 
have come out differently? Had it remained a minority language, forcing 'Britons' either to travel to acquire fluency or to study languages properly in school to gain proficiency, they might have remained more attuned to the European prospect.

The same thought returns us to a twist on Defoe's poetic invocation of mixture: English was not the only language spoken on the 'sceptred isle' either in his time or Shakespeare's. For that matter, English itself is a combination of Anglo-Saxon, Latin and French, so it is a polyglot product. What is hybrid is sold as unitary. It is worth noting that in Richard II Bolingbroke responds to his exile as "enforcèd pilgrimage", which his father regards as a foil that will set off "The precious jewel of thy home return". ${ }^{33}$ Bolingbroke promises to remain "Though banished, yet a true-born Englishman". ${ }^{34}$

In Shakespeare's history cycle the triumphant moment comes in Henry $V$ with its staging of the famous victory at Agincourt and the assertion of Henry's dynastic claim to France. This play makes the composite nature of the monarchy more conspicuous, not least with the cameo of Macmorris with his stage Irish speech and famous query "What ish my nation?", but more obviously with the comic presence of the Welsh, notably in the figure of Llewellyn (Fluellen), with whom Henry acknowledges kinship as descendant of a Welsh family himself. ${ }^{35}$ What is more, the play draws attention to the problem of the Scots. They will take any opportunity to stir up trouble and invade if the English dally in Continental wars. For this reason, some of the nobility and their forces must remain behind, leaving Henry outnumbered against the French, although of course he proves more glorious in victory over them as a result. At least the Scots merit respect in this regard; the other 'nations' of the realm are appropriated as comic supporting parts in an English drama of self-realisation. This is so despite the fact that Ireland is promised to Princess Catherine of France as part of her enticement to marry the victorious English sovereign. ${ }^{36}$

Henry $V$ turns on kinship registered as hostility in rival claims for patrimony. In the peace negotiations at the close of the play (Act V, scene ii) the king of France is addressed as brother and his wife as sister. Yet there is still an elaborate playing out of old opacities in the wooing scene between Henry and Catherine (his future Queen Consort) where neither has fluency in the other's language. As Henry remarks - speaking prose, interestingly, in this scene: "It is as easy for me, Kate, to conquer the kingdom as to speak so much more

\footnotetext{
33 Shakespeare (2016), 1.3.253, 256.

34 Shakespeare (2016), 1.3.272.

35 Shakespeare (2016), 4.7.89.

${ }_{3} 6$ See Shakespeare (2016), 5.2.210.
} 
French. I shall never more move thee in French, unless it be to laugh at me". ${ }^{37}$ Most of this is set up to the disadvantage of Catherine, to English ears at least, though as part of the comic closure the scene is played affectionately rather than as rough wooing: "Your majesté 'ave faux French enough to deceive de most sage demoiselle dat is en France". ${ }^{38}$ The paradox is that the audience must understand some French to get the joke. What Henry proposes is an alliance in which their hybrid prodigy will fight a common foe: "thou must therefore needs prove a good soldier-breeder: shall not thou and I, between Saint Denis and Saint George, compound a boy, half-French, half-English, that shall go to Constantinople and take the Turk by the beard?"39

The prospect of engaging in new adventures in conquest promises to knit together old oppositions. Something of the same hope, in a secularised vein, seems to inspire the questing for new trade deals in the post-Brexit agenda.

But the promised triumphs may be as vanishing as Henry's glory. It is worth remembering how the next play in Shakespeare's historical sequence (Henry $V I$ ) opens - with the funeral march for Henry V, his demise coming quickly after his celebrated victories. News of setbacks in France quickly mounts up, punctuated by a bold address from a messenger reporting on military misfortunes in the country:

Awake, awake, English nobility!

Let not sloth dim your honours new-begot!

Cropped are the flower-de-luces in your arms;

Of England's coat, one half is cut away. ${ }^{40}$

The capacity of Shakespeare to offer us plots that allegorise the present is undoubtedly rich. Cymbeline, his historical romance of resistance in Roman Britain, represents a particularly noteworthy drama from this point of view. King Cymbeline is a vassal to Rome. His two sons having been stolen away in their childhood, he is left only with a beautiful daughter, Innogen. She suffers at the hands of a plotting step-mother, Cymbeline's queen, who seeks to wed Innogen to her loathsome son Cloten, despite the fact that she has already married Posthumus Leonatus (without her father's consent). Disputes with Rome provide an important backdrop to the romance action. Cymbeline refuses to pay the tribute he owes to Rome, rejecting the appeals of the Roman

\footnotetext{
37 Shakespeare (2016), 5.2.166-8.

38 Shakespeare (2016), 5.2.194-5.

39 Shakespeare (2016), 5.2.183-6.

40 Shakespeare (2016), 1.1.78-81.
} 
ambassador who invokes the prospect of a new invasion in retaliation. Some complicated plot twists lead Innogen to Milford Haven, where it transpires that her lost brothers have been raised (in ignorance of their true paternity). Their courage shines forth as they fight against the Roman forces. Innogen, disguised as a boy, Fidele, is held by the Romans, who have been joined by her husband. The Britons overcome their opponents, and Cymbeline contemplates executing his adversaries, but he pauses when Fidele comes to his attention. Romance resolution ensues, with Cymbeline's valiant sons restored to him, and Innogen to her Posthumus, allowing comedy to be rescued from tragedy.

And what of the Romans? Cymbeline makes peace with them, blaming his decision to refuse their demands on his late queen (who dies acknowledging her plots against him and Innogen). The king remarks:

Although the victor, we submit to Caesar,
And to the Roman empire, promising
To pay our wonted tribute, from the which
We were dissuaded by our wicked Queen. ${ }^{41}$

Thus the political situation, in spite of all the intricate skirmishing, ends up where it began. Will this, one wonders, prove to be the case with the UK's ostensible departure from the EU? Representatives of the Remain campaign must hope for the predictive power of the Soothsayer's speech, the penultimate one in the play. He states:

For the Roman eagle

From south to west on wing soaring aloft

Lessened herself, and in the beams o'th' sun

So vanished; which foreshadowed our princely eagle,

Th'imperial Caesar, should again unite

His favour with the radiant Cymbeline. ${ }^{42}$

Cymbeline himself endorses this conclusion in the final lines, proclaiming: "Let / A Roman and a British ensign wave / Friendly together", ${ }^{33}$ before proposing a march through London. The balance that Constance Jordan finds in the ending of Cymbeline: "At the play's conclusion Britain remains a vassal state of Rome, but she retains the fundamental liberties she would have were she

\footnotetext{
41 Shakespeare (2017), 5.5.459-62.

42 Shakespeare (2017), 5.5.469-74.

43 Shakespeare (2017), 5.5.478-8o.
} 
independent of Rome, ${ }^{34}$ might express the hopes of Remainers or those who seek the softest of Brexits with as close an alliance with the EU as possible. Advocates for Brexit, meanwhile, harp on about the vassal state position of Britain in the EU and, in their more extreme moments, insist on withholding the $£_{39}$ billion divorce bill, refusing this 'tribute' to a foreign overlord.

\section{Coda: Churchillian Contradictions}

The contradictions in British identity and the relationship to Europe have persisted over time, constituting an ongoing legacy. The aftermath of World War II and the efforts to create lasting peace through economic cooperation deepened the conflict over separateness or integration for British politicians rather than resolving it. Winston Churchill embodied these contradictory impulses. He remains an important figure since, as Boris Johnson remarks in a selfserving biography, "thrusting young Tories - and especially males - will regard Winston Churchill as a sort of divinity." 45 Yet Johnson is forced to acknowledge that Churchill also occupies this deified role in a European context, as "one of the presiding divinities of the European Union". ${ }^{46}$ Churchill articulated a view in favour of a United States of Europe as early as 1930 and endorsed it again in a speech in Zurich in September 1946 supporting the creation of what became the Council of Europe. ${ }^{47}$ Yet Johnson is right to suggest this is not the whole of the story. Hugo Young, from a very different political perspective, affirms that "most of Churchill's blueprints, however, placed Britain/England outside the European construct." 48 The country would somehow stand apart while encouraging European integration, ${ }^{49}$ moving in an orbit determined by commitments to the Empire and Commonwealth, and a vision, as Churchill saw

\footnotetext{
44 Jordan (1997), p. 69. For a valuable study of the play, see King (2005).

45 Johnson (2014), p. 31.

46 Johnson (2014), p. 290.

47 For Churchill's supportive speeches and contributions to the Council, see archived sources on the Council website https://www.coe.int/en/web/documents-records-ari chives-information/winston-churchill-and-the-ce.

48 Young (1998), p. 13.

49 In a speech to the Commons (as leader of the opposition) on 27 June 1950, Churchill stated: "I cannot conceive that Britain would be an ordinary member of a Federal Union limited to Europe in any period which can at present be foreseen [...]. Although a hardand-fast concrete federal constitution for Europe is not within the scope of practical affairs, we should help, sponsor and aid in every possible way the movement towards European unity. We should seek steadfastly for means to become intimately associated with it." Quoted in Johnson (2014), p. 293.
} 
it, of the English speaking peoples in alliance (including, above all, the US). Britain's role as a world power would continue.

In these discussions, Ireland remained vestigial. During the referendum campaign the country was equally ignored. Northern Ireland and scope for a return to violence in the event of a hard border scarcely figured in public debate (Tony Blair and John Major gave a joint address in Derry two weeks before the vote, warning against a Leave outcome and appealing to the undecided, but their advice was ignored). The blithe dismissal of this concern by many advocates of Brexit is a shocking reminder of the low priority attached to Irish concerns.

What of Churchill himself? As a liberal he supported Home Rule, writing in 1911 that

It must always be a guiding star of British statesmanship not only to federate the Empire, but to draw nearer in bonds of friendship and association to the United States. The road to the unity of the English-speaking races is no doubt a long one, and we cannot see the end of it. But it is an open road, and an Irish parliament, loyal to the Crown, and free to make the best of the Emerald Isle, is assuredly the first milestone upon it. ${ }^{50}$

This invocation draws attention to the line of thinking developed in Churchill's four-volume History of the English-Speaking Peoples (1956-58). Ireland does not feature in any prominent way in the history, which is noteworthy in itself, but the country does intrude in the nineteenth-century narrative. Recounting the struggles for Home Rule, he remarks that "it must not be supposed that the Irish picture can be seen from Britain entirely in black and white."51 Describing from earlier in the century the cause of Daniel O'Connell and Catholic Emancipation, Churchill notes a speech in the House of Lords by Wellington (whose Irish origins he points out) and the stark words Wellington spoke in relation to the potential for civil war:

I am one of those who have probably passed a longer period of my life engaged in war than most men, and principally in civil war; and I must say this, that if I could avoid by any sacrifice whatever even one month of civil war in the country to which I was attached I would sacrifice my life in order to do it. ${ }^{52}$

5 Q Quoted in Roberts (2018), p. 163.

$5^{1} \quad$ Churchill (1956-58), vol. 4, p. 27 O.

$5^{2} \quad$ Churchill (1956-58), vol. 4, p. 3 o. 
The warnings about Ireland are there, in other words, even in Tory sources.

Churchill ended his history on a note of uncertainty:

Here is set out a long story of the English-Speaking Peoples. They are now to become Allies in terrible but victorious wars. And that is not the end. Another phase looms before us, in which alliance will once more be tested and in which its formidable virtues may be to preserve Peace and Freedom. The future is unknowable, but the past should give us hope. Nor should we now seek to define precisely the exact terms of ultimate union. ${ }^{53}$

Brexiteers have lost contact with the post-war inspiration to unify Europe, opposing the strategy of creating supranational institutions in order to interlock the fate of nations in the European continent. ${ }^{54}$ Meanwhile, they look to old alliances, largely Anglophone in the first instance - with America and the Commonwealth (i.e. English-speaking peoples) - to mitigate the consequences of departure.

Taking an early modern perspective on the longue durée of Brexit reveals not only the durability of a sense of separateness but also the tensions and inconsistencies within it. When Linda Colley reviewed the emergence of a British identity in her 1992 book Britons. Forging the Nation 1707-1837, she observed that the driving forces leading to this artificial construct (protracted war with France; Protestant religious difference; and the fight to retain and expand an empire) had disappeared in the late twentieth-century moment in which she wrote: not only in the loss of overseas territories but in Protestant religious attachments. She saw the appearance of more assertive forms of Welsh, Scottish and even English nationalism as responses to "a broader loss of national, in the sense of British, identity". In a remark that now reads as prophesy, she commented:

Indeed, now that it is part of the European Economic Community, Great Britain can no longer comfortably define itself against the European powers at all. Whether it likes it or not, it is fast becoming part of an increasingly federal Europe, though the agonies of British politicians and voters of all partisan persuasions so plainly experienced in coming to terms with Brussels and its dictates show just how rooted the perception of Continental Europe as the Other still is. ${ }^{55}$

53 Churchill (1956-58), vol. 4, p. 304.

54 For an account, see O'Rourke (2019).

55 Colley (1992), p. 6. 


\section{Bibliography}

Black, Jeremy (2019). Britain and Europe. A Short History (London: Hurst \& Co.).

Borsing, Christopher (2017). Daniel Defoe and the Representation of Personal Identity (Abingdon: Routledge).

Bradshaw, Brendan, John Morrill (eds) (1996). The British Problem, c. 1534-1707. State Formation in the Atlantic Archipelago (Houndmills, Basingstoke: Macmillan).

Bradshaw, Brendan, Peter Roberts (eds) (1998). British Consciousness and Identity. The Making of Britain 1533-1707 (Cambridge: Cambridge University Press).

Churchill, Winston (1956-58). A History of the English-Speaking Peoples, 4 vols (London: Cassell).

Colley, Linda (1992). Britons. Forging the Nation 1707-1837 (New Haven: Yale University Press).

Connelly, Tony (2018). Brexit and Ireland. The Dangers, the Opportunities, and the Inside Story of the Irish Response. Updated edn. (London: Penguin Books).

Cottret, Bernard (2019). Les Tudors. La démesure et la gloire, 1485-1603 (Paris: Perrin).

[Defoe, Daniel] (2003), 'The True-Born Englishman. A Satyr', in Satire, Fantasy and Writings on the Supernatural by Daniel Defoe, gen. eds W. R. Owens and P. N. Furbank, vol. 1, The True-Born Englishman and Other Poems, ed. by W. R. Owens (London: Pickering \& Chatto).

Defoe, Daniel (200o). Robinson Crusoe, ed. by Thomas Keymer (Oxford: Oxford University Press).

Dickens, A. G. ([1964] 1989). The English Reformation. 2nd edn (London: B. T. Batsford). Haigh, Christopher (1993). English Reformations. Religion, Politics, and Society under the Tudors (Oxford: Clarendon Press).

Helgerson, Richard (1992). Forms of Nationhood. The Elizabethan Writing of England (Chicago: University of Chicago Press).

Heuser, Beatrice (2019). Brexit in History. Sovereignty or a European Union? (London: Hurst \& Co.).

Johnson, Boris (2014). The Churchill Factor. How One Man Made History (London: Hodder \& Stoughton).

Jordan, Constance (1997). Shakespeare's Monarchies. Ruler and Subject in the Romances (Ithaca: Cornell University Press).

Joyce, James (2000). Occasional, Critical, and Political Writing, ed. by Kevin Barry (Oxford: Oxford University Press).

Kerrigan, John (2008). Archipelagic English. Literature, History, and Politics 1603-1707 (Oxford: Oxford University Press).

Knapp, Jeffrey (2002). Shakespeare's Tribe. Church, Nation, and Theater in Renaissance England (Chicago: University of Chicago Press). 
King, Ros (2005). Cymbeline. Constructions of Britain (Aldershot: Ashgate, 2005).

MacCulloch, Diarmaid (2016). All Things Made New. Writings on the Reformation (London: Penguin).

Marshall, Peter (2017). Heretics and Believers. A History of the English Reformation (New Haven: Yale University Press).

Mason, Roger A. (ed.) (1994). Scots and Britons. Scottish Political Thought and the Union of 1603 (Cambridge: Cambridge University Press).

Mason, Roger A. (2004). 'Scotland, Elizabethan England and the Idea of Britain', Transactions of the Royal Historical Society, 14, pp. 279-293.

May, Theresa (2017). 'ANew Era of Cooperation and Partnership between the UK and the EU.' Speech delivered 22 September in Florence at https://www.gov.uk/government/ speeches/pms-florence-speech-a-new-era-of-cooperation-and-partnership-betweenthe-uk-and-the-eu [accessed 17.4.2019].

O'Rourke, Kevin (2019). A Short History of Brexit. From Brentry to Backstop (London: Pelican Books). First published 2018 as Une brève histoire du Brexit. Nous sommes tous concernés, trans. Christophe Jaquet (Paris: Odile Jacob).

O’Toole, Fintan (2018). Heroic Failure. Brexit and the Politics of Pain (London: Head of Zeus).

Roberts, Andrew (2018). Churchill. Walking with Destiny (London: Allen Lane).

Robertson, John (ed.) (1995). A Union for Empire. Political Thought and the British Union of 1707 (Cambridge: Cambridge University Press).

Sassen, Saskia (1996). Losing Control? Sovereignty in an Age of Globalization (New York: Columbia University Press).

Sassen, Saskia (2008). Territory, Authority, Rights. From Medieval to Global Assemblages. Updated edn. (Princeton: Princeton University Press).

Schmidgen, Wolfram (2013). Exquisite Mixture. The Virtues of Impurity in Early Modern England (Philadelphia: University of Pennsylvania Press).

Shakespeare, William (2016). 'Richard II', in The Complete Works. Modern Critical Edition, ed. by Gary Taylor, John Jowett, Terri Bourus, Gabriel Egan (Oxford: Oxford University Press).

Shakespeare, William (2016). 'Henry V', in The Complete Works. Modern Critical Edition, ed. by Gary Taylor, John Jowett, Terri Bourus, Gabriel Egan (Oxford: Oxford University Press).

Shakespeare, William (2016). 'Henry VI', in The Complete Works. Modern Critical Edition, ed. by Gary Taylor, John Jowett, Terri Bourus, Gabriel Egan (Oxford: Oxford University Press).

Shakespeare, William (2017). Cymbeline, ed. by Valerie Wayne (London: Bloomsbury). Shipman, Tim (2017). All Out War. The Full Story of Brexit. Rev. edn. (London: William Collins). 
Walker, Simon (2004). 'John [John of Gaunt], duke of Aquitaine and duke of Lancaster, styled king of Castile and León (1340-1399)', in Oxford Dictionary of National Biography, ed. by H. C. G. Matthew, Brian Harrison (Oxford: Oxford University Press), vol. 3०. pp. 174-183.

Young, Hugo (1998). This Blessed Plot. Britain and Europe from Churchill to Blair (London: Macmillan). 
PART 2

Identity Politics of the Neo-Right 


\title{
From Identity Politics to the Identitarian Movement
}

\author{
The Europeanisation of Cultural Stereotypes?
}

\author{
Karel Šima
}

\begin{abstract}
The motivation behind this contribution is to explain how the concept of identity got from the emancipatory context of identity politics to the conservative revolutionary context of nationalistic, xenophobic, far-right movements of the Generation Identity. On one hand the notion of identity was mobilised to challenge the dominant oppressive power relations by the marginal social groups based mainly on distinctiveness of ethnicity, race, gender etc. On the other hand, recent crises in Europe brought to the fore the far-right youth movements that posed the defence of identity as their main motto. The aim of this contribution is to analyse cultural references within the discourses and performances of the pan-European identitarian movement in order to understand their mechanisms of instrumentalising national, ethnic, as well as local and European cultural characteristics and values. This case study is of relevance as it not only shows cultural representations behind specific social movements reacting to recent European crises, but also explains the processes by which they are being 'europeanised' into pan-European cultural and political discourses.
\end{abstract}

\section{Introduction}

On 27 August 2016 fifteen activists from a German identitarian group climbed the iconic Brandenburg Gate in Berlin and put up banners reading "Secure borders - secure future" ["Sichere Grenzen - sichere Zukunft"] and "Protect Borders! Save lives!" ["Grenzen schützen! Leben retten!']. This demonstration took place near government buildings on a day when they were open to the public. In their performance, witnessed by a large audience, these activists presented a political agenda based on the image of an enemy from outside and gained 
significant coverage in regional as well as national media. ${ }^{1}$ More than one year later, on the $5^{00^{\text {th }}}$ anniversary of Luther's famous posting of the ninety-five theses in Wittenberg, these activists put on a "street theatre show" in front of a Berlin church, where one of them dressed as Martin Luther nailed a poster with five theses against the protestant church of Germany to the door. They criticised the church for selling "modern indulgences" in the form of refugee aid and for betraying its ideals and earning "billions" for destroying Europe. These performers also unfurled a banner featuring a picture of Luther with an identitarian logo on his forehead and emblazoned with one of his quotations: "Hypocrisy has ample wages, but truth goes a-begging" ("Für Heuchelei gibt's Geld genug, Wahrheit geht betteln"). This event was completely overlooked by the media, and photos and a corresponding statement were only published on the Facebook page of Berlin's identitarian group. ${ }^{2}$ These two demonstrations illustrate the paradoxes of this relatively recent 'movement' that has, on one hand, gained substantial media coverage, but on the other consists of small, locally marginal groups of activists that possess few resources. Identitarians play with national symbols and stereotypes, while at the same time reacting to overarching European agendas. They raise controversial political questions, but instead of engaging in political debate they counter the establishment by mixing cultural references. They communicate their agenda through social media, dressing up their traditionalist and mostly conservative political ideas in an attractive visual style. They combine the political instruments of leftist social movements with far-right ideology.

There is not much new about this self-declared pan-European identitarian 'movement,' ${ }^{3}$ except its clever strategy of exploiting its own paradoxes in an attempt to shift the mainstream public discourse towards the far right. Its strategy is based on the French New Rights ideology, which places culture at the centre of political struggle. Therefore, identitarians refuse to use classic political instruments, and instead, in their struggle for cultural hegemony, recycle and put to innovative use cultural references that reflect European and national hetero- and autostereotypes and thus frame national and European political debates with their ideology. Following this idea, I will first show how

1 See 'Rechte "Identitäre Bewegung" besetzt Brandenburger Tor' (2016).

2 All identitarian Facebook pages were banned during the first half of 2018. The author has archived copies of these pages.

3 Fabian Virchow persuasively argues that this activist current is neither 'identitarian' nor a 'movement'. Although I use the term 'identitarian' in this paper, I put 'movement' in quotation marks in keeping with Virchow's interpretation. When mentioning particular national identitarian organisations, I refer to them by the name they use. See Virchow (2015), p. 186. 
and why the concept of identity moved from the context of identity politics to become the key political driver in the identitarian 'movement'. Then I will shortly summarize the identitarian current that has been surging through Europe since 2012, before introducing its key ideological pillars and showing how identitarians put them into practice in their public cultural performances. In the conclusion I will consider the differences between different European identitarian groups and shortly reflect on this "movement's" perspectives.

\section{From Identity and Identity Politics to Identitarian Counterattack}

Social scientists and humanities scholars have long debated the concept of identity; in the 199os the scholarly discourse on identity became so widespread and was used in so many different contexts, often with vague conceptual justifications, that some authors saw no value in further developing identity theories and instead suggested using other more precise and analytically robust concepts. For example, Brubaker and Cooper differentiate between identity as a category of analysis and as a category of practice. ${ }^{4}$ While they oppose the analytical power of the concept, they acknowledge that identity in practice should be studied in the process of its reification. Thus, the key question is, how and in which circumstances can the concept of identity become a category of social, political, and cultural practice? Along these lines, I will explore the identitarian 'movement' as a specific mutation of identity politics.

Beginning in the nineteenth century, when identity ceased to be taken for granted, several forms of modern identity politics that revolved around concepts of nation, state, or class emerged. They replaced what Calhoun calls "the all-encompassing identity schemes" of the premodern era. ${ }^{5}$ In the 1950s and 196os in Western Europe and the USA identity politics began to focus on improving the lives of ethnic and sexual minorities. Even though the public discourse had changed and legal changes officially improved their status, they remained marginalised groups. At this time, the push for equal civil rights for these marginalised groups began to revolve around each group's specific 'way of life.' Thus, a new identity politics emerged that sought recognition of differences. As a result of this shift, identity politics was adopted by some new social movements (NSMs), as these activist groups were later labelled. ${ }^{6}$

4 See Brubaker, Cooper (2000).

5 Calhoun (1994), p. 11.

6 For a reflection of the concept of identity in NSM research, see, e. g., Scott, Benford, Snow (1994). 
In the 196os the term 'identity' had so thoroughly permeated the public discourse that Robert Coles complained that it had become "the purest of clichés". ${ }^{7}$ Hand in hand with the establishment of this term within academic discourse, identity became a category of practice. The term 'identity politics' emerged in the 1970s, when several NSMs grew into visible political forces providing radical critiques of the existing order. In the 1970s and 1980s activists promoting women's liberation, gay liberation, environmentalism, animal rights, the anti-nuclear movement, African-American civil rights, and other similar movements succeeded in achieving recognition and legitimacy for their agendas within the broader political discourse through various protest practises. The New Left's success in the 199os (in Britain, the USA and Germany, for example) thrust identity politics into the political mainstream and resulted in the gradual creation of an organisational and funding infrastructure. Simon Bornschier notes that this success story has not only its winners but also its losers. What he calls "cultural modernisation" has largely benefited "sociocultural specialists", who work in "client-interactive environments" with a high degree of cultural diversity. ${ }^{8}$ In opposition to them stand those who oppose cosmopolitan values and defend the traditionalist monocultural conception of community. In the 199os, however, leftist and liberal academics began to criticize the New Left's turn towards identity politics. Scholars such as Eric Hobsbawm and Richard Rorty warned that the Left's focus on identity would amount to a loss of its electorate and pave the way for dangerous populist politicians. ${ }^{9}$ A new wave of criticism has emerged following the financial and migration crises of recent years, when liberals have been shocked by the gains of populist right-wing political entrepreneurs. ${ }^{10}$ Identity politics is now facing an identitarian counterattack.

The Identitarian Wave in a Time of Crisis and Its Roots in Far-Right Politics

The official kick off of the European identitarian 'movement' that initiated the Generation Identity brand internationally was a local protest held on 20 October 2012 in Poitier, France. Several dozen activists occupied a mosque under construction, unfurling black-and-yellow banners that read "Generation

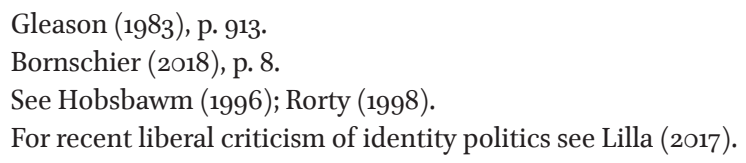


Identitaire $73^{2}$ and featured the Greek lambda symbol.1 ${ }^{11}$ These activists had a well-established background in the Bloc Identitaire party that was founded in 2003 as a successor to Unité Radical, a far-right political group that was banned after a member attempted to kill the president. The French radical right already had a rich history of political activism behind it before this protest. However, the Poitier demonstration featured several new twists. As Bruns, Glösel and Strobl point out, the four core elements of the international identitarian 'movement' were on display here: youth, actionism, popular culture and corporate identity. ${ }^{12}$

The 'movement' promotes itself as a generational response to the crises of European civilisation. This clarification has helped it distinguish itself from other existing far-right groups and create an image of youthful authenticity. The follow-up to the Poitier demonstration is a simple black-and-white YouTube video titled Declaration de Guerre (A Declaration of War) featuring angry young men and women speaking about their wasted lives and clearly blaming an unnamed "you".13

The actionist element lies in the way their angriness is expressed. The Poitier demonstration was an audacious, visually attractive protest that owed much to Greenpeace's style; it was presumably designed to get media attention - from classic mass media to social media. Its brief message was deeply symbolic, referring to the Reconquista and the Battle of Tours (also known as the Battle of Poitier), where Charles Martel defeated a Muslim army of the Umayyad Caliphate in 732 . The identitarians adopted a strategy involving visually striking, media-attractive forms of protest that are not based on the number of protesters but on performative creativity and cultural references and stereotypes.

These activists frequently incorporate visual and textual pop-culture references in their materials. The 'movement's' main symbol is the Greek letter lambda, a symbol the Spartan army painted on its shields. This image, however, does not come from historical sources, but from 300, a popular comic book adapted into a Hollywood movie in 20o6. Some of the "movement's" videos, which are critical communication channels and mobilisation tools, borrow heavily from the film's visual aesthetics, particularly in their depiction of excitement, courage and peril. Identitarians use pop culture and history to make their agenda accessible and attractive.

The identitarian 'movement' has also built up a 'corporate identity' as a new element in the far-right scene. The first demonstration in Poitier featured the

\footnotetext{
11 For details, see Glösel, Strobl, Bruns (2014).

12 Glösel, Strobl, Bruns (2014), p. 56.

13 See Génération Identitaire (2013).
} 
basic components that identitarian groups from different countries still use today: the lambda symbol, the "generation identity" label, black-and-yellow graphics, and references to a modern-day 'Reconquista'. Although groups act independently on the national level, their visual style is maintained across national borders. The 'movement' thus copies the strategy of multinational corporations, which build global brands that are adopted nationally. The identitarian brand, however, emphasizes pan-European values and identity.

The 'movement's' common ideological and 'corporate' framework cannot make up for the national differences rooted in the far-right political scenes of each country. Fabian Virchow even doubts whether the identitarians can even be called a movement at all, as they possess only some of the key characteristics necessary for defining a group as a social movement. ${ }^{14}$ Therefore, he suggests identitarianism is a proto-movement with an open future. In recent years, the organisation of the 'movement' has stabilised: stable local groups are connected under the banner of a national group, which in some countries, such as Austria, has an overall leader. International cooperation, however, seems to be rare and occurs only on an ad hoc basis.

Now I shall examine the special features of identitarianism in different countries. I will start in France, the cradle of this 'movement'. The French organisation Génération Identitaire draws its ideology from the French New Right (see the next section), a connection French identitarians heavily market. It is also the national group that most resembles a youth political organisation. In fact, it was established as the youth wing of Bloc Identitaire at a time when this political group had ambitions of entering party politics. However, the success of Marine Le Pen's National Front that began in 2011 moved Bloc Identitaire away from party politics; it changed strategies and sought to become a political association with a broader impact on society. Through their Maison de l'Identité cultural and social centres and various media and publishing activities, ${ }^{15}$ they attempted to influence a wider audience in a 'grassroots' style. In 2016 the name of the organisation was changed from Bloc Identitaire to Les Identitaires, but the Génération Identitaire youth group remained a vital part. Apart from online activism, the youth organisation also held an annual summer school focused not only on political education, but also on practical political work (journalism, video recording and processing, banner making, etc.) and sport (boxing, self-defence). The French identitarian organisation

\footnotetext{
14 Virchow (2015), p. 186.

15 In March 2021 the youth organisation was dissolved by the French government on the grounds of inciting people to hatred and hostility. For the Les Idenititaires, see https:// www.les-identitaires.com/ [accessed 01.05.2019] and the websites of their regional groups.
} 
featured two attributes that distinguish it from other groups. Firstly, it prides itself in its role as the initiator of the international 'movement'. Secondly, it accentuates national symbols and stereotypes, highlighting historical figures such as Saint Genevieve, the patron saint of Paris, and making references to foods linked to national autostereotypes.

In Germany the Poitier protest and video found relatively wide popularity in 2012. Several identitarian groups were quickly founded. The first medialised protest was held in Frankfurt's municipal library during "Intercultural Week"; several activists in Guy Fawkes masks disrupted an event, blaring hardbass music, unfurling a banner with the identitarian logo and holding up a sign reading "bassing out multiculti" ("Multikulti wegbassen"). ${ }^{16}$ Since then identitarian groups have organised several protest performances that have received some media attention. Although these groups present themselves as a centrally organised movement with chapters in each Bundesland and national leaders, ${ }^{17}$ the overall organisational structure is fragmented and decentralised with some groups acting relatively independently, whereas others are inactive.

The Austrian identitarian movement has many links to the German one. The leading Austrian identitarian author, Markus Willinger, was born in Austria but studies in Stuttgart. He is author of the key German-language manifesto Die identitäre Generation: Eine Kriegserklärung an die 68er (Generation Identity: A Declaration of War Against the '68ers). ${ }^{18}$ Identitarians in both countries also draw from a shared far-right scene that produces journals such as Sezession, Neue Freiheit, and Blaue Narzisse. However, the Austrian identitarians, when compared to their German counterparts, are more active and better organised. The earliest groups were established in university cities with strong links to right-wing student clubs. ${ }^{19}$ Martin Sellner, a student at the University of Vienna and member of the far-right Burschenschaft Olympia student group, is the most visible national identitarian leader on a global scale. ${ }^{20} \mathrm{He}$ is the co-leader of the Austrian branch and has attracted the most media coverage by far. Austrian identitarians have succeeded not only in establishing a network of regional contact persons, but also in organising several regular events, including annual conferences, summer courses and numerous protest performances. So called "annual reports" and regular press reports contribute to building up their 'corporate identity'.

16 Glösel, Strobl, Bruns (2014).

17 See their website https://www.identitaere-bewegung.de/ [accessed 24.03.2021].

18 See Willinger (2014).

19 See Speit (2016).

$20 \quad$ See Weidinger (2016), p. 82 . 
Although a Swiss-German identitarian branch was launched in 2014, it is mostly inactive. Its activities are limited to copying German materials and presenting them on the internet and Facebook pages. Similarly, Swiss-French identitarians are heavily dependent on Génération Identitaire.

In Scandinavia, where there is an active and visible far-right scene that has been strongly influenced by French identitarian writers, identitarian groups lack the corporate style of continental European branches; their links to German and French identitarians are more virtual then real. As Benjamin Teitelbaum argues, the shift towards identitarianism is a part of a broader trend within the Nordic far-right scene, which has experienced the declining popularity of the skinhead subculture in favour of intellectualism and engagement in the culture wars. ${ }^{21} \mathrm{He}$ describes identitarianism as one of the three new nationalist streams in Scandinavia that has gradually evolved since 2004 under the influence of the French New Right ideology. After establishing an umbrella organisation, the National League, Scandinavian identitarians succeeded in developing three online platforms with international influence. From 2006 to 2015 the Motpol multiblog was highly popular among activists around Europe. ${ }^{22}$ Around the same time the Wikipedia-like platform Metapedia featuring identitarian content was established and soon translated into a number of languages. ${ }^{23}$ The third platform was the Nordisk.nu site featuring varied content, including discussion fora and music, with a peak of 20000 registered users. With the exception of Nordisk.nu, these platforms still exist today; in general the Scandinavian far-right scene still has a significant impact on other European groups mainly via Arktos Media, which publishes seminal works of the New Right and other ideologies, as well as fiction, history, and philosophy books in English. On the other hand, the complete absence of the Generation Identity corporate identity in Scandinavia is surprising at the very least and could be the result of older far-right activists dominating the scene.

In southern Europe, only Italy has an active identitarian scene. Since 2012 several Generazione Identitaria groups have been established; they draw heavily from their high-profile Rome-based neo-fascist CasaPound forerunners and also have French inspiration. They have adopted the identitarian corporate identity including the main themes of Reconquista, ethno-pluralism, and support for youth sport. Their protest style includes using stickers to express political messages in public spaces. For example, in 2018 they affixed stickers reading "islamizzazione" (Islamisation) to stop signs in the centres of many

\footnotetext{
21 See Teitelbaum (2017).

22 See https://motpol.nu/ [accessed 23.03.2021].

23 See https://en.metapedia.org [accessed 23.03.2021].
} 
Italian cities. ${ }^{24}$ This strategy resembles the culture jamming strategies of anti-consumerist movements inspired by the French Situationist International from 196os onwards.

In 2017 several groups emerged in other western and southern European countries, such as the Belgian Generatie Identiteit and the Danish Identitaer. In the United Kingdom and Ireland, the identitarian group was officially launched in 2017 and started to be active in 2018 and there is a sign of identitarian activities in Spain in Catalonia.

There is a clear distinction in the transfer of identitarianism to postsocialist countries. National branches in the Czech Republic and Slovenia have been in continuous existence since 2013, put on regular public performances, and possess their own, partly specific, styles. Both groups were established in regions bordering German-speaking countries and were inspired by their neighbours' activist scenes. The Hungarian group's beginnings date back to 2014, but it started to be more active in 2016. In 2017 when the identitarian "Defend Europe" campaign gained international attention, several other Eastern European branches attempted to organize independent actions. The Polish Pokolenie Tożsamości is not stable, but it took part in a Polish nationalist demonstration in 2017. A Serbian group also organised several protests and debates in 2017.

If we examine European identitarianism as a whole, several regional distinctions emerge. Firstly, identitarianism is clearly centred in France and Germany, countries that have inspired the Scandinavian and Eastern European far-right scenes. Additionally, in these two countries, where immigration is a hotly debated topic, far-right politics in general have seen a resurgence. In France there is a strong traditional right-wing party that supports smaller groups. In Germany the far right has only moved away from the edge of legality in recent years with the establishment of anti-immigrant political parties and movements (AfD, Pegida). Identitarian metapolitics offers a promising strategy in this country with strong anti-hate-speech legislation.

Secondly, postsocialist countries either have been influenced by the German-language activist scene (Czech Republic, Slovenia) or have their own far-right political groups that are part of the political mainstream (Poland, Hungary). The lack of a still active generation of '68ers' and weakened liberal political currents also weaken the image of the alleged enemy of the identitarian 'movement' there.

24 For their own presentation of this campaign, see https://generazione-identitaria.com [accessed 24.03.2021]. 
Thirdly, Scandinavia and southern European countries have strong domestic far-right scenes, and identitarian groups there do not follow the identitarian corporate style; thus, active groups in Spain and Sweden tend to follow more their own national traditions of far-right politics.

The ideological roots of the identitarians lie in GRECE, a New Right group founded in 1968, and the ideas of its founders, Alain Benoist and Guillaume Faye. Benoist summarised his longstanding criticism of liberal egalitarianism in an eclectic and sometimes contradictory essay titled On Identity that was first published in French in the GRECE journal Éléments. ${ }^{25}$ It was later translated into English, German, and Italian and reworked into the book Nous et les Autres. Problématique de l'identité. ${ }^{26}$

He starts by establishing identity as a distinct modern concept present in the academic discourses of psychology, sociology, and social anthropology. Drawing from Charles Taylor's communitarian approach to identity, among other things, he sketches a narrative of the modernist notion of identity beginning with the eighteenth-century philosophy of individualism, Descartes's rationalism, and Locke's philosophy of free will. With the presumed crisis of Western nation-states, which had long been modern man's main source of selfrecognition, the need for an alternative base for identity-building had come. He refers to contemporary minority identity politics (giving examples of gay, African-American, and ethnic movements) without contextualising them in the identity politics of NSMS, and ascribes them a non-universalist position as opposed to the modernist liberal notion of group interests. In this way he presents them as victims of the modern universalist claim that identity is a private matter. This interpretation allows him to claim that inherited differences must be accepted and considered part of one's identity: belonging to a group "will only determine [one's identity] if belonging to a nation or to any other entity is the decisive criterion for one's thoughts and actions". ${ }^{27}$ Here Benoist openly shifts the function of identity. It is no longer a problem of modern society that should be studied or something that minority groups struggling for recognition should grasp; it is one's cultural heritage that needs to be 'accepted' in the face of modern liberal universalism.

\footnotetext{
25 See Benoist (2004a).

26 See Benoist (2006).

27 Benoist (2004b), p. 42.
} 
It should be noted that Benoist also criticizes essentialism, which overestimates the stability of identity and overlooks its constantly changing nature. In a section on the pathology of identity he mentions that even if the presence of an enemy gives a group a social identity, it is only a negative identity and not an expression of identity in its own right. He also calls for identities to be constructed in a dialogic process, based on one's relationship with the other; thus identities should not mutually exclude each other. Behind this call for dialogue, however, lies the ethno-pluralist approach of the New Right, which states that the unique traditions and cultures of nations and ethnic groups have to be kept separate in order to preserve them. ${ }^{28}$ Benoist's concept, which was highly popular among nationalists around Europe, is formulated as a positive notion of difference and inconspicuously but tellingly leaves aside the need to separate different identity groups implicit in it.

If Benoist's argumentation clearly demonstrates continuity with NSM identity politics, the strategy identitarians have built on these ideological grounds transforms this continuity into the performative context of specific cultural and historical stereotypes. An illustrative example is the "Defend Europe" motto around which various campaigns were organised. In 2017 a nine-minute video was made using materials from different national identarian groups with the goal of unifying European identitarianism. ${ }^{29}$ It begins with marching young people prominently displaying the identitarian symbol before a title card reading "Defend Europe" appears; it then focuses on different countries, showing national symbols and each branch's activities. The German part starts with shots of the Niederwald Monument and the Hermann Monument, which commemorate the nineteenth-century unification of Germany and the pre-Christian Germanic victory over Romans, respectively. This is followed by an intertitle reading "European people are dying because we are tolerant to those who don't respect our identity." The rest of the clip portrays various manifestations and public performances arranged by country. The final shot is of the Acropolis in Athens with the identitarian lambda flag in the foreground. A title card reading "United for our children" then appears.

The video presents a disparate mix of images--shots from tourism videos depicting nationalist memorials and amateur footage from youth demonstrations. It combines alarmist rhetoric with symbols of national glory and the determination to defend them. Hence, it refers to both national and European popular memory, the source of the identity endangered by a vaguely presented

28 See Rydgren (2007), p. 244.

29 See Spotlight70o (2017). 
enemy. While Benoist writes about 'accepting' and 'considering' one's own identity, this presentation conjures up ideas of active "defence" against an external enemy.

This "defence" rhetoric has been put into action during numerous protests and performances around Europe, such as the Paris Pride March (Marche de la journée de la fierté Parisienne). Since the early 200os, a group called Paris Pride (Fierté Paris) has organised, alongside identitarian groups from Paris, evening-time torch-lit marches around the feast day of Saint Genevieve (January 3) under the slogans "Defend Paris" or "Defence of Paris" ("Défendons Paris" or "Défence de Paris"). ${ }^{30}$ The defence rhetoric is also present in speeches made during this event, where speakers compare Saint Genevieve's defence of Paris against Attila the Hun to the present goal of defending it against Islamists.

Other minor performances using similar rhetoric have also been organised, usually in the form of banner drops in public spaces. One example would be a demonstration held by Czech identitarians -- the unfurling of a banner reading "Our people first" ("Naši lidé na prvním miste"”) at the National Gallery in Prague in front of Ai Weiwei's Law of the Journey, an installation consisting of a large inflatable boat and inflatable figures wearing life vests. A photo was published on the Czech identitarians' webpage with the caption "Our politics is not based on hate towards others but love for our own kind" ("Naše politika nevychází z nenávisti k ostatním, ale z lásky ke svým"). ${ }^{31}$ This statement demonstrates the paradox of the identitarian position: they claim they care just about "our" identity, but through performance they communicate symbolic messages of war against an internal and external enemy.

The identitarian campaign that has received the most international attention was the Defend Europe "mission"; its aim was to block search-and-rescue ships operated by NGOs in the Mediterranean. This "mission" was launched in spring 2017 with a fundraising campaign targeting American and European far-right supporters. Identitarian activists hired the C-Star, which departed from Djibouti; however, there were severe complications with finding a place to dock on European shores. For example, Northern Cyprus detained the ship's crew over accusations of people smuggling. The activists finally began their

30 It has been reported on mostly by far-right media in recent years as for example TV Libertés, Paris Vox, Novopress and French branches of Russian international media as Sputnik France and Russia Today France. See also the organizers' clips on YouTube, e. g. https://www.youtube.com/watch?v=amk5 Y7bRS6E [accessed 24.03.2021].

See Generace Identity (2017). 
mission in late July 2017. ${ }^{32}$ When the ship needed to be refuelled, it was blocked repeatedly by NGOS, local citizens, and the Tunisian and Maltese authorities; it ended up finishing its "mission" after one week of patrolling the seas. While having no impact on the activities of NGOs, the activists claimed that they were "monitoring" the situation and "trolling" NGOs using megaphones and banners reading "No way, you will not make Europe home" and "Stop human trafficking". ${ }^{33}$ Nevertheless, they proclaimed the "mission" to be an "undisputable and total success". ${ }^{34}$

Although this campaign lacked the references to cultural or historical identity of earlier demonstrations, it exemplifies the strategy identitarians use to transform the performance style of the old identity politics to meet their purposes. Since the early 1970s, Greenpeace has been conducting maritime blockades, most famously by the Rainbow Warrior. Hiring out a ship, however, did not help the identitarians make any practical changes, but it did gain them international publicity. Taking their cue from the protest culture of the established environmental movement, they have adapted it to their political agenda, in the process gaining attention in the media as the battleground of the cultural wars.

The ideological background of this strategy lies in the concept of metapolitics that was developed within the French New Right and is based on the Gramscian notion of cultural hegemony. As Benjamin Teitelbaum notes, when New Right authors studied their political opponents it brought them to the strategy of "pulling themselves and likeminded activists out from the margins of public life and injecting their message into the mainstream". ${ }^{35}$ These theorists, referencing Gramsci, claim that political change must begin with cultural struggle. In a 2011 manifesto Guillaume Faye writes that "social diffusion of ideas and cultural values for the sake of provoking profound, long-term, political transformation" is needed. ${ }^{36}$ While ideologues were debating these ideas in relative isolation in France in the 1970s and 1980s, during the 1990s the concepts of ethnopluralism and metapolitics spread widely among nationalists throughout Europe. In the 2ooos they were introduced to the identitarian 'movement', including its youth organisations.

\footnotetext{
32 This campaign was widely covered by international and national media in Europe. For a summary produced by the antiracist and antixenophobic think-tank Hope Not Hate, see Mulhall (2017).

33 Oppenheim (2017).

34 Defend Europe (2017).

35 Teitelbaum (2017), p. 42.

$36 \quad$ Faye (2011), p. 272.
} 
Although preserving culture is a crucial goal for identitarians, there is surprisingly little discussion about the definition of culture in identitarian ideological texts. Based on observations of identitarian performances, 'culture' could cover everyday culture, pop culture, traditional folk culture, collective memory, art, and even the humanities or scholarship in general. I will now present different examples of how European identitarian groups, in their protests and performances, have addressed culture in its various forms.

Identitarians perceive the internet and public space as crucial arenas of metapolitics. They use references to everyday mainstream culture to present their agenda through cultural auto- and heterostereotypes. In the 2000 s the French Bloc Identitaire used stereotypes about French food to play the anti-immigrant card. Their most medialised performance protest was the distribution of soup de cochon or soup identitaire ("pork soup" or "identity soup") to homeless people in areas in French cities with Muslim and Jewish populations in the 20oos. These activities peaked with a highly controversial performance that was planned for Paris in 2010 and titled "pork sausage and booze party" ("apéro saucisson et pinard"), which was banned by local police after protests by various local communities. ${ }^{37}$

The erection of a memorial to "the victims of multiculturalism and Islamic terror" (as it was presented in the right-wing media) in Berlin in 2017 was a public performance that referred to cultural memory in multiple ways. ${ }^{38}$ This performance was part of the German identitarians' new strategy of establishing single-purpose campaigns linked to topical issues discussed in the public arena. ${ }^{39}$ On the first anniversary of the massacre on Berlin's Breitscheidplatz, where a truck was driven into the Christmas market in December 2016, city authorities dedicated a monument to this event at the site of the attack. While a ceremonial unveiling was taking place on Breitscheidplatz, several identitarians constructed a concrete monument in front of the Brandenburg Gate. Activists set five concrete blocks there inscribed with the slogans "To the victims of Islamist terror" ("Den Opfern Islamistischen Terrors") and "No victim is forgotten" ("Kein Opfer ist vergessen") and the names of European cities where terrorist attacks had been committed in recent years. After several hours the blocks were removed by the police as they were placed there illegally. ${ }^{40}$ This

\footnotetext{
37 Mestre and Monnot (2010).

$38 \quad$ Berger (2017).

39 They establish specific websites with short statements and clips without open references to the identitarian 'movement'. See e. g. https://www.identitaere-bewegung.de/projekte/ kein-opfer-ist-vergessen/ [accessed 24.03.2021]. 
performance act made at least three cultural references. Firstly, the image of concrete blocks resembles the Holocaust memorial that was erected nearby in 2005. Hence, identitarians linked Islamists with the denounced Nazi regime to legitimize their protest. Secondly, candles, photos, and flowers were laid out, making the monument resemble an authentic mourning site. The audience of this act was supposed to perceive the place as an authentic place of memory. Thirdly, it reflected the media debate about the inscription on the official monument at Breitscheidplatz, where the word Islamist was not included in the official inscription. By including this word in their inscription the identitarians targeted the alleged hypocrisy of the authorities. Even though this performance touched upon many controversial issues, it gained only minor publicity in the local media.

Identitarians also react to current political issues popular in the media to support their own agenda. For instance, in 2018 a group of German identitarians started a media campaign in reaction to the \#MeToo campaign against sexual assault and harassment. It was called the 120 Decibel movement with the subtitle "the real outcry", a reference to the volume of pocket alarms used by women in danger, and calls upon women to speak about their experience with "imported violence". ${ }^{41}$ In addition to producing a mobilisation video, campaign organizers have also disrupted a panel discussion about the \#MeToo campaign at the Berlinale film festival and put on a street theatre performance titled "Dead Girls Don't Lie" ("Tote Mädchen lügen nicht") in front of the parliament in Schleswig-Holstein. This campaign links depictions of fear and vulnerability with the need for speaking out on violence against women, an idea borrowed from the \#MeToo campaign to legitimize the exaggeration of immigrant violence and arouse xenophobia.

The Czech identitarian 'movement' has most prominently protested by recontextualising meaning in contemporary art. Apart from the protest in the National Gallery mentioned above, the Czech identitarian group also stepped into the public realm by conducting an "aesthetic intervention" in Prague in November 2016. The subject of their protest was controversial Czech artist David Černý's sculpture in the courtyard of the Kafka Museum. Activists covered Černýs fountain - featuring the statues of two men urinating on a map of the Czech Republic - with a tarp, wrapped it up in black-and-yellow tape, and spread political leaflets around it. A report on the group's website refers to the fountain as "quasi-art that is vulgar and offends the Czech nation". ${ }^{42}$ Even

41 The campaign's website has been deleted since then.

42 Generace Identity (2016). 
though Černý is well known for his provocative artworks in public spaces that question Czech autostereotypes, this performance had little public impact.

The identitarians have also co-opted traditional folk culture events, most notably in Germany. In 2016 and 2017 identitarians from Harz snuck into the carnival parade in the town of Derenburg masked as Spartan warriors, holding shields marked with the lambda sign and pushing a figure dressed as Angela Merkel, who was dishonouring the German flag. ${ }^{43}$ Even though the president of the carnival association was outraged, the organizers did nothing to stop them. The president argued that the carnival is not meant to promote any political group or party; its main aim is "fun". ${ }^{4}$ The identitarians countered on their Facebook page by claiming that political statements are present at various German carnivals. A similar performance was organised by the identitarian group from Schwaben in January 2018, when activists disrupted a parade, masked in burkas and carrying a banner reading "Women rights movement Burkaria 2022, equal in rights, self-determining, free" ("Frauenrechtsbewegung Burkaria 2022, gleichberechtigt, selbstbestimmend, frei"). Local police investigated this act because some of the carnival participants complained about the content of the leaflet that identitarians had distributed. The group proclaimed their demonstration to be a great success and added that "carnival, as a hundred-year-old custom, is perfectly suitable for holding up a mirror to society and its elites".45 Through "mirroring" mainstream cultural practices identitarian ideology is put into action and presented to a local public.

\section{Conclusions: The Europeanisation of Far-Right Youth Culture?}

Identity as a category of practice has undergone a strange shift in recent decades. Rooted in the academic discourse of the 1950s and 1960s, it became a key concept in the anti-establishment radical movements of the 1970s and 1980s, which opposed the mainstream discourse by raising the self-consciousness of marginalised groups. New Right ideologues observed the success of these NSMs in the 199os and gradually adopted an ideological framework with which they could fight against NSMs' agendas on the same field. In the 2000 s these thinkers offered a solid ideological foundation for a new generation of far-right activists fighting against the liberal and universalist mainstream. From their political opponents the far right adopted culture as the main

\footnotetext{
43 Freie-Heimat (2017).

44 Volkstimme.de (2017).

45 Widemann (2018).
} 
political battleground, and it adapted the left's forms of protest that attract public attention. Use of the internet and social media and cultural performances have been established as the key instruments for promoting political agendas. As NSM strategies were accepted by the mainstream, they eventually made their way to the far right, where the original focus on universal rights and identity politics came under attack by the identitarian 'movement', which claims to defend the cultural identity of the majority.

The new far right in the West has marked '68ers' as the main enemy for having disrupted the traditional value system. Although identitarians present themselves as a pan-European movement, this 'enemy' is not equally strong in all European countries. Identitarianism has been most successful in France and German-speaking countries, whereas in Scandinavia, southern Europe it has not caught on so well. In the United Kingdom the identitarian groups have mobilised new activists and gained public presence as late as 2018. Interesting borderline cases are the Czech Republic and Slovenia. This European divide was further exacerbated by mass immigration to France and Germany during the 2015 crisis. In southern Europe only Italian identitarians have successfully organised their own demonstrations. Consequently, it supports the thesis that the new far-right, which sees its enemy in migrants and '68ers', has been the most successful in European core countries. Follow-up research, however, is still necessary.

As identitarians oppose the modern liberal paradigm of history because it contradicts memory (as formulated by Pierre Nora), the frame of reference in national, European, and regional memory and mythology plays a very important role. Identitarians have fought on the "battleground of culture" by carefully mobilising historical and cultural stereotypes as part of cultural performances that are attractive to the mainstream media. Modern notions of history as the scientifically reconstructed knowledge of the past have taken a back seat to a highly selective process of forming a collective memory.

Thus, the far-right identitarian 'movement' just mirrors the strategies initially developed by new social movements in their pursuit of identity politics and universal rights, which gives this proto-movement rather limited perspectives for the future. Even though identitarians have successfully addressed a specific section of the youth in some European countries, their role in shifting the general public discourse towards a xenophobic and nationalist agenda has been rather insignificant in comparison to that of established far-right political parties, which have grown in popularity in Europe since the immigration and economic crises.

Furthermore in 2018 and 2019 state authorities in France, Austria and Germany started to check the legality of identitarians' organisations and activities. Their vigilant and guarded strategy helped them to defend their position, for 
example in a legal dispute in Graz, Austria, where they were accused of criminal association and hate speech but found not guilty. Throughout the year 2018 the Facebook and Instagram pages of identitarian groups in various countries were banned, which was followed by establishing new ones which were again banned. With this new repressive wave, the identitarian 'movement' seems to be neither weakened nor reinforced and remains a marginal but stable part of the far-right political scenes throughout Europe. ${ }^{46}$

\section{Bibliography}

Benoist, Alain (2004a). 'Qu'est-ce que l'identité ?'. https://s3-eu-west-1.amazonaws. com/alaindebenoist/pdf/qu_est_ce_que_l_identite.pdf [accessed o1.05.2019].

Benoist, Alain (2004b). 'On Identity', Telos, 128, pp. 9-64.

Benoist, Alain (2006). Nous et les Autres. Problématique de l'identité (Paris: Crisis).

Berger, David (2017). 'Brandenburger Tor. Erstes europäisches Denkmal für die Opfer von Multikulti und islamistischen Terrorismus'. https://philosophia-perennis. com/2017/12/19/ib-brandenburger-tor/ [accessed 24.03.2021].

Bornschier, Simon (2018). 'Globalization, Cleavages, and the Radical Right', in Jens Rydgren (ed.), The Oxford Handbook of the Radical Right (Oxford: Oxford University Press). https://www.oxfordhandbooks.com/view/10.1093/oxfordhb/9780190274559 .001.0001/oxfordhb-9780190274559-e-11 [accessed 24.03.2021].

Brubaker, Rogers, Frederick Cooper (2000). 'Beyond “Identity", Theory and Society, 29.1, pp. 1-47.

Calhoun, Craig (1994). 'Social Theory and the Politics of Identity', in Craig Calhoun (ed.), Social Theory and the Politics of Identity (Oxford: Blackwell), pp. 9-36.

Defend Europe (2017). The Successes of Defend Europe (online video recording), YouTube, 23 August. https://www.youtube.com/watch?v=NpsDDtOC-yc [accessed 23.03.2021].

Faye, Guillaume (2011). Why We Fight. Manifesto of the European Resistance (London: Arktos).

Freie-Heimat (2017). Identitäre Bewegung Harz - Beitrag zum Aschermittwoch (online video recording).YouTube, 1 March.https://www.youtube.com/watch?v=BteFK44Li3g [accessed 01.05.2019].

Generace Identity (2016). 'Estetická intervence v Praze'. http://generace-identity.cz/ tag/david-cerny/ [accessed 23.03.2021].

46 This work was supported by the European Regional Development Fund project "Creativity and Adaptability as Conditions of the Success of Europe in an Interrelated World" (reg. no.: CZ.o2.1.01/o.o/o.o/16_o19/oooo734). 
Generace Identity (2017). 'Estetická intervence „Naši lidé na prvním místě“ v Národní Galerii'. http://generace-identity.cz/esteticka-intervence-nasi-lide-na-prvnimmiste-v-narodni-galerii/ [accessed 01.05.2019018].

Génération Identitaire (2013). Déclaration de guerre - Génération Identitaire (version sans musique) (online video recording), YouTube, 20 January. https://www.youtube. com/watch?v=5Vnss7ygTNA [accessed 23.03.2021].

Gleason, Philip (1983). 'Identifying Identity. A Semantic History', The Journal of American History, 69.4, pp. 910-932.

Glösel, Kathrin, Natascha Strobl, Julian Bruns (2014). Die Identitären. Handbuch zur Jugendbewegung der Neuen Rechten in Europa (Münster: Unrast Verlag).

Hobsbawm, Eric (1996). 'Identity Politics and the Left', New Left Review, 217, pp. 38-47.

Hunt, Scott, Robert D. Benford, David A. Snow (1994). 'Identity Fields. Framing Processes and the Social Construction of Movement Identities', in Enrique Larana, Hank Johnston, Joseph R. Gusfield (eds), New Social Movements (Philadelphia: Temple University Press), pp. 185-209.

'Identitäre Bewegung stellt Grabsteine vor Brandenburger Tor' (2017). Die Welt, 19.12.2017. https://www.welt.de/politik/deutschland/article171744110/IdentitaereBewegung-stellt-Grabsteine-vor-Brandenburger-Tor.html [accessed 23.03.2021].

Klein, Adam (2017). Fanaticism, Racism, and Rage Online. Corrupting the Digital Sphere (London: Palgrave Macmillan).

Lilla, Mark (2017). Once And Future Liberal. After Identity Politics (Toronto: HarperCollins).

Mestre, Abel, Caroline Monnot (2010). 'Extrême droite. L'apéro "saucisson et pinard" de la Goutte-d'Or interdit', 16 June. https://www.lemonde.fr/societe/article/2010/o6/16/ extreme-droite-l-apero-saucisson-et-pinard-de-la-goutte-d-or-interdit_1373693_3224. html [accessed 23.03.2021].

Mulhall, Joe (2017). 'Failed Defend Europe Mission Comes to an End'. https://www.hopenothate.org.uk/2017/o8/17/failed-defend-europe-missioncomes-end/ [accessed 23.03.2021].

'Rechte “Identitäre Bewegung” besetzt Brandenburger Tor' (2016). Die Welt, 27 August. https://www.welt.de/newsticker/dpa_nt/infoline_nt/brennpunkte_nt/article157879235/ Rechte-Identitaere-Bewegung-besetzt-Brandenburger-Tor.html [accessed 24.03.2021].

Oppenheim, Maya (2017). 'Defend Europe. Far-RightShipStopping Refugees Ends Its Mission after a Series of Setbacks', The Independent, 21 August.https://www.independent.co.uk/ news/world/europe/defend-europe-far-right-ship-stop-refugees-mediterranean-endmission-c-star-setbacks-migrant-boats-a7904466.html [accessed 24.03.2021].

Rorty, Richard (1998). Achieving Our Country. Leftist Thought in Twentieth-Century America (Cambridge, Mass: Harvard University Press).

Rydgren, Jens (2007). 'The Sociology of the Radical Right', Annual Review of Sociology, 33, pp. 241-62 
Speit, Andreas (2016). Bürgerliche Scharfmacher. Deutschlands neue rechte Mitte - von AfD bis Pegida (Zürich: Orell Füssli).

Spotlight70o (2017). Europeans Unite to Defend Europe (online video recording), YouTube, 18 March. https://www.youtube.com/watch?v=Tsjh 5 FoNxNo\&t=296s [accessed 01.05.2019].

Teitelbaum, Benjamin R. (2017). Lions of the North. Sounds of the New Nordic Radical Nationalism (New York: Oxford University Press).

Virchow, Fabian (2015). "The "Identitarian Movement". What Kind of Identity? Is it Really a Movement?', in Patricia Anne Simpson, Helga Druxes (eds), Digital Media Strategies of the Far Right in Europe and the United States (Lanham, Maryland: Lexington Books), pp. 177-19o.

Volkstimme.de (2017). "Derenburg geht auf Distanz". https://www.volksstimme.de/ lokal/wernigerode/karneval-missbraucht-derenburg-geht-auf-distanz [accessed 24.03.2021].

Weidinger, Bernhard (2016). 'Völkische Studentenverbindungen und Rechtsextremismus in Österreich', in Albert Steinhauser, Harald Walser (eds), Rechtsextremismus-Bericht 2016 (= Bericht zu den Ergebnissen der „Rechtsextremismus-Enquete“ der Grünen von 2015) (Vienna: Die Grünen - Der Grüne Klub im Parlament), pp. 77-87. Widemann, Wolfgang (2018). "Rechte Gruppierung mischt sich unter Narren im Faschingsumzug", Augsburger Allgemeine, 30 January. https://www.augsburgerallgemeine.de/donauwoerth/Rechte-Gruppierung-mischt-sich-unter-Narren-imFaschingsumzug-id44029536.html [accessed 24.03.2021].

Willinger, Marcus (2014). Die identitäre Generation (London: Arktos). 


\title{
Re/nationalising EU-rope
}

\author{
National Identities, Right-Wing Populism, and Border-and Body-Politics
}

\author{
Ruth Wodak
}

\begin{abstract}
In almost every EU member state, and beyond, we are experiencing the rise of farright/right-wing populist parties, accompanied by a virulent (nativist) nationalism and related body and border politics. Not only are borders being closed and walls constructed, in order to keep specific groups of people (refugees and immigrants) out; the programs also contain many elements of a patriarchal, anachronistic gender and family politics. This contribution discusses such nationalistic body politics which has become visible in many election campaigns and in, for example, the notorious 'headscarf debate', the 'Burkini debate', and the debate about the so-called 'unwillingness to integrate'. The contribution then proceeds to a qualitative case study on how the Austrian Freedom Party has recontextualised the discourse about 'Volk' and 'Volkskörper' in recent years, in order to advance its populist, xenophobic and gendered agenda and to normalise their far-right political positions. Using the Discourse-Historical Approach (DHA), it discusses the complex strategies with which the party has combined backstage and frontstage approaches in this struggle for a new discursive hegemony.
\end{abstract}

\section{Introduction}

Since the 1980s, the transformation of the former Eastern bloc, Germany's reunification, the enlargement and deeper integration of the European Union, together with persistent debates on immigration, migration and flight, focused attention on issues of historical and cultural (local, regional and national) identities. In the Member States of the European Union, the propagation of a new European identity was accompanied by the emergence or re-emergence of fragmented and unstable national and ethnic identities. Seemingly established collective, national identities became contested political terrain and the focus of political struggles. Research focusing on the constitutive role of 
discourse - and particularly language - in the construction of national identities ${ }^{1}$ has drawn on the valuable contributions in historiography, sociology and political science. $^{2}$

More recently, threats and crises of various kinds have re-invigorated discussions of national or cultural identities across Europe. Thus, nationalism, once declared an obsolete force, especially after World War II and the establishment of the European Union, has obviously returned with renewed vigour. Nationalism nowadays must be perceived as a global phenomenon - we encounter passionate nationalist movements everywhere, in Africa, South-America, the Middle East, Southern Europe, and in the successor states of the former Soviet Union. Frequently, new nationalisms emerge, tied to religious beliefs such as Islamic nationalism. Indeed, it seems to be the case that - despite an ever more unified and globalised world -, more borders and walls emerge, defining nation states and protecting them from dangers both alleged and real.

Of course, it is important to emphasize that the idea of the nation also encompasses inclusiveness and solidarity; simultaneously, belonging to a nation is frequently defined through ethnic and even racist categories (rather than, e.g., legal citizenship), thus excluding 'Others' who do not possess these characteristics and are marginalised as outsiders, as strangers. In this way, our identities are inherently tied to subjective feelings of belonging, on the one hand; as well as to imposed nationalistic, religious, and ethnic categories, on the other. Identity, in this complex struggle over belonging, is never static and defined once and for all; identity and identities are dynamic, fluid and fragmented; they can be renegotiated, according to socio-political and situative contexts as well as to more global social change and ideologically informed categories. Therefore, the German sociologist Theodor W. Adorno famously claimed, "[i]dentity is the prototype of ideology".

Taking Adorno's words on board, the manifold ways in which national identity and nationalism are functionalised nowadays by right-wing populist and far-right parties with the aim of, on the one hand, constructing the 'real' Hungarians, Austrians, Dutch, Finns or British and, on the other, of excluding all the 'Others' who are considered as not belonging to the respective group, should be investigated. Delanty and Kumar rightly emphasize that "nationalism is present in almost every aspect of political community and social arrangements. It pervades the global and local dimensions and can even take cosmopolitan

\footnotetext{
1 See Boukala (2013); Sicurella (2016); Krzyżanowski (2010); Wodak et al. (2009); Wodak (2011); (2015a), (2015b), (2017), (2019a).

2 See Gellner (1983); Anderson (1995); Haller et al. (1996); Rathkolb (2011); Billig (1995).

3 Adorno (1966), p. 151.
} 
forms". ${ }^{4}$ The 'real' people are defined not by having obtained citizenship to a specific country (ius soli), but by having been born to parents who already belonged to the respective country, i.e., by nativist principles or ius sanguinis. ${ }^{5}$ If push comes to shove, this can even be extended to a vaguely defined cultural or even linguistic 'belonging'. Such opinions are held not only by the far-right; they are endorsed more and more strongly by mainstream parties who - out of fear of losing votes - accommodate such right-wing populist views. Because of continuous fear mongering related to debates about security and the protection of 'our social welfare' (social welfare chauvinism), the ground has shifted. ${ }^{6}$

With respect to Austrian national identities, these developments have been the subject of discourse-analytical studies in the tradition of critical theory, leading to the elaboration of an interdisciplinary framework that integrates a form of Critical Discourse Studies with approaches from the political sciences, historiography and sociology in the Discourse-Historical Approach (DHA). ${ }^{7}$ Although the framework was developed through studies related to Austria, the theoretical as well as the general analytical findings provide insight into widespread patterns of discursive nationalisation within other modern nation-states. Indeed, the DHA has since been widely acknowledged by the international scientific community and applied in studies of the discursive construction of national identities in numerous countries in Europe and South America, but also in Canada, the USA, Australia and China. ${ }^{8}$

The year 2015 offered a unique opportunity to continue previous research into the discursive construction of Austrian identity and in so doing update the underlying approach and framework. On the one hand, 2015 was a significant commemorative year for Austria - 20 years of EU membership, 70 years since the Declaration of Independence, 6o years since the State Treaty, 200 years since the Congress of Vienna, 650 years for the University of Vienna. On the other hand, it presented the opportunity to trace the discursive construction of Austrian identities in a longitudinal perspective by connecting to previous work focused on and using similar data in 1995 and 2005. The resulting perspective spans analyses from over 20 years within the same theoretical framework, making it both unique and innovative in the international field of research. ${ }^{9}$

Firstly, this contribution reviews the underlying assumptions about the discursive construction of national identities and discusses the concepts of

4 Delanty, Kumar (2006), p. 3.

See Mudde (2007).

6 See Wodak (2015b).

7 See Wodak (2011); Wodak (2015a); Reisigl, Wodak (2009).

8 See for example Blackledge (2009); Ricento (2003).

9 See De Cillia, Wodak, Rheindorf, Lehner (2020). 
'nation' and 'national identity'. Secondly, I briefly present the Discourse-Historical Approach, including recent conceptual and methodological adaptations. I then thirdly focus on the Austrian far-right populist party FPÖ, both backstage and frontstage, and its nationalist nativist ideologies; and elaborate some interdependences of extreme-right positioning on backstage and frontstage while deconstructing the visions of an Austrian nativist national identity. ${ }^{10}$

Nations, following Anderson, are constructs represented in the minds, memories and social practices of nationalised subjects as sovereign and limited political units. ${ }^{11}$ Nations, like all other communities that are larger than face-to-face groups, constitute what Anderson calls "imagined communities". Nonetheless, they can function as very influential guiding ideas with sometimes grave and destructive consequences. Members of even the smallest nations do not know the majority of their fellow-citizens, do not meet, do not hear from one another. And yet they are convinced of belonging to a unique national community, not least because they largely read the same newspapers, watch the same TV programmes or listen to the same radio programs, etc. Nations are perceived as limited by boundaries and thereby cut off from the surrounding nations, because no nation identifies with humanity in its entirety.

We argue that such national identities - conceived as specific forms of social identities - are not in any biologist or culturalist sense essential or naturally given, but are discursively produced, reproduced, transformed and destructed by means of language and other semiotic systems. National identities are constructed, inter alia, by emphasising a common history, and thus through remembrance and memory. Maurice Halbwachs' notion of "collective memory" denotes the selective recollection of past events which are thought to be important for the members of a specific community. ${ }^{12}$ This notion allows researchers to trace a connection between often abstract discourses on national identities, myths, symbols and rituals of everyday life, ${ }^{13}$ or popular culture, increasingly in the form of "banal nationalism". ${ }^{14}$ Collective memory in Halbwachs' sense maintains historical continuity by recalling specific elements

\footnotetext{
10 Rheindorf, Wodak (2019).

11 See Anderson (1985), p. 15.

12 Halbwachs (1985).

13 See Breuss, Liebhart, Pribersky (1995), p. 553.

14 Billig (1995).
} 
from the archive of historical memory. This concept is of particular interest for an analytical approach to the discursive construction of national identities, especially regarding the question of which events are selected for a "national history" and how they are narrativised by a nation's representatives (e.g. the head of state), institutions (e.g. courts, schools), the media, and private citizens in constructing a shared history, present and future. ${ }^{15}$ The fact that such history is constructed through discursive practices has been described as the "anthropological primacy" of language:

[...] language becomes the primary factor without which no recollection and no scientific transposition of this recollection is possible. The anthropological primacy of language for the representation of past history thus gains an epistemological status, for it must be decided in language what in past history was necessitated by language and what was not. In anthropological terms, any 'history' constitutes itself through oral and written communication between generations that live together and convey their own respective experiences to one another. ${ }^{16}$

Approaches in cultural studies and sociology emphasize the role everyday life and culture play in the construction of nations and national identities. Stuart Hall describes nations not only as political constructs, but also as "systems of cultural representations" that allow an imagined community to be interpreted in meaningful ways. ${ }^{17}$ People are not only citizens by law, they also participate in creating the imaginary of 'their' nation as represented in a common national culture. Through such self-representation - which has a counterpart in representations of other nations - the symbolic community of a nation is discursively constructed.

A national culture is a discourse, a way to construct meanings which influence and organize both our actions and our perceptions of ourselves. National cultures construct identities by creating meanings of 'the nation', with which we can identify; these are contained in stories that are told about the nation, in memories which link its present to its past and in the perceptions of it that are constructed ${ }^{18}$

\footnotetext{
15 See Berger, Wodak (2018).

16 Koselleck (2002), p. 27.

17 Hall (1994), p. 200.

18 Hall (1994), p. 201.
} 
Beyond being simply part of culture, languages have often played a crucial role in the formation of modern nation states such as France, glossing over or actively repressing existing multilingualism through legislation, education and administrative practice. With respect to the construction of distinctiveness and homogeneity of national languages, language policy remains a key field of social and political action.

Pierre Bourdieu's notion of habitus provides a crucial perspective in the sense that national identities can be regarded as a sort of habitus, that is to say as a complex of common ideas, concepts or perception schemes, i.e. (a) related emotional attitudes intersubjectively shared within a specific group as well as (b) similar behavioural dispositions, which are (c) internalised through 'national' or 'nationalising' socialisation. ${ }^{19}$ The national subject, in other words, is discursively produced. In the case of the Austrian nation, the ideas and schemata in question refer to the imagined concept of the homo Austriacus (and the femina Austriaca), the 'quintessential' or 'typical Austrian'.

In as much as the modern nation state is a territorial state and seeks to define its extension within clear-cut geographic borders, the discursive construction of national identities relates to notions of home, homeland or 'Heimat'. What are constructed as 'natural' and 'agricultural' landscapes as well as the built environment thus constitute a type of national body that often supports identification, feelings of belonging and pride. Insofar as this body also always has a more or less extensive past, this dimension of national identity may relate closely to the shared past and may or may not be constructed as co-extensive with a national culture and/or language.

In terms of all of the above - national past, culture, language, body and self-representation - the discursive construction of national identities is always concomitant with the construction of difference/distinctiveness and uniqueness. ${ }^{20}$ In short, to be discursively constructed as Austrian may more or less strongly rely on contrast, even opposition to constructions of other national identities (e.g. German) with respect to, inter alia, the national narrative, culture or language.

As internalised habitus as well as discursive construction, the reproduction and transformation of national identities is always also a question of power relations and hegemony. The constructivist perspective outlined above emphasizes that there is no such thing as the one and only national identity in an essentialising sense, but rather that different identities are discursively constructed,

19 See Bourdieu (1994).

$20 \quad$ See Hall (1994); Hall (1996); Wodak (2017). 
co-constructed and negotiated, according to specific socio-political and situational contexts, that is according to the social field, the situational setting of the discursive act and the topic being discussed. In other words, national identities are not completely consistent, stable and immutable. Rather, as already mentioned above, they are dynamic, fragile, fluid, and often incoherent. However, previous work has shown that the relations (of transfer and contradiction) between identity constructions offered by political elites, the media and everyday discourses are not arbitrary or random but rather purposeful and contextually determined.

Border and body-politics are part of national identity politics and are now once again increasingly defined by the national language (the mother tongue), by ethnicity and culture, transcending the political borders of the nation state. ${ }^{21}$ Instead of cosmopolitanism, post-nationalism, a European citizenship and the common European language policies which promote multilingualism, we seem to be witnessing a re/inventing of traditional, parochial, closed nation states. Such tendencies have also been observed by Skendorovic who - while analysing the Swiss right-wing populist party's (SVP) policies and history - concludes that "the radical right's conception of nationhood and national identity offers patterns of interpretation premised on the idea that sociocultural, political, or historical groups are based on natural distinctions." 22 Griffin accordingly concludes that the radical right "takes on highly culture-specific forms, largely because it draws on a nationalist myth whose contents are unique to each cultural tradition". ${ }^{23}$ Obviously, the concept of 'mother tongue' relates to nativist body politics of viewing and conceptualising the nation as a body with the mother tongue symbolising the national language. ${ }^{24}$

Thus, in contrast to discursive and social constructivist approaches to nationalism elaborated above, 'nation' as defined by far-right populist parties is a limited and sovereign community that exists and persists through time and is tied to a specific territory (space), inherently and essentially constructed through an in/out (member/non-member) opposition and its out-groups. Access to national identity/membership is defined via heritage and ancestry, thus via 'blood'. ${ }^{25}$ Such a notion of nation and nationalism is closely tied to concepts underlying racism; however, it is important to emphasize here that neither is racism necessarily nationalist, nor nationalism necessarily racist. For

\footnotetext{
21 See Wodak (2015a); Rheindorf, Wodak (2018).

22 Skendorovic (2009), p. $18 \mathrm{f}$.

23 Griffin (1999), p. 316.

24 See Musolff (2010).

25 See de Cleen (2012), p. 97.
} 
example, the connection to a territorial space must be perceived as a structural component of nationalism, but not of racism. While racism as ideology and practice depends on the arbitrary definition of groups and their fallaciously generalised negative characteristics, due to biological categories, nationalism need not. Nevertheless, the conceptual boundaries are certainly blurred. ${ }^{26}$

Four assumptions serve as foundations for this analysis:

1. Identities are always re/created in specific contexts. They are co-constructed in interactive relationships. They are usually fragmented, dynamic and changeable, but not mutually exclusive - everyone has multiple identities.

2. Identity construction always implies inclusionary and exclusionary processes, i.e., definitions of 'Us' and 'Them'. Linguistic competence of the national language (the 'mother tongue') has acquired the status of a gatekeeper in posing obstacles for migrants.

3. Identities that are individual and collective, national and transnational are also re/produced and manifested symbolically, in many genres, while drawing on a range of linguistic/pragmatic/rhetorical/narrative and argumentative resources.

4. Far-right populist nationalism inherently endorses an essentialised concept of nationalism expressed in ever more restrictive (nativist) body politics (Kulturnation). Mainstream political parties accommodate more and more to essentialised national body politics to keep their electorate from voting for far-right parties and their values; in other words, far-right ideologies become normalised.

\section{The Discourse-Historical Approach}

In my case study below, I adopt the discourse-historical approach (DHA). This approach provides a vehicle for looking at latent power dynamics and the range of potentials in agents, because it integrates and triangulates knowledge about historical, intertextual sources and the background of the social and political fields within which discursive events are embedded. Moreover, the DHA distinguishes between three dimensions which constitute textual meanings and structures: the topics which are spoken/written about; the discursive strategies employed; and the linguistic means that are drawn upon to realize both topics and strategies.

26 See Reisigl, Wodak (2001); de Cleen (2012). 
The DHA is widely applied in research on identity politics, populism, discriminatory rhetoric, and so forth, and allows the systematic relating of macroand mezzo-levels of contextualisation to the micro-level analyses of texts. Such analyses consist primarily of two levels, an 'entry-level analysis' focusing on the thematic dimension of texts, and an 'in-depth analysis' which deconstructs the coherence and cohesion of texts in detail. The general aim of the entry-level thematic analysis is to map out the contents of the texts being analysed. The key analytical categories of thematic analyses are discourse topics, which, "conceptually summarize the text, and specify its most important information".27 The in-depth analysis, on the other hand, is informed by the research questions and consists of the identification of the genre (e.g., TV interview, policy paper, election poster, political speech or homepage), analysis of the macro-structure of the respective text, the strategies of identity construction and of the argumentation schemes, as well as of other means of linguistic realisation it uses.

'Discourse' is defined as follows, emphasising argumentation (i.e. people with different opinions, attitudes and ideologies speaking and arguing about the same macro-topic) and the distinction between ideology and discourse as constitutive factors from the outset:

[...] a cluster of context-dependent practices that are situated within specific fields of social action; socially constituted and socially constitutive; related to a macro-topic; linked to the argumentation about validity claims such as truth and normative validity, involving several social actors who (may) have different points of view. ${ }^{28}$

In the DHA, two further concepts emerge as salient for analysing politically salient phenomena: first, 'intertextuality' refers to the linkage of all texts to other texts, both in the past and in the present. Such links can be established through continued reference to a topic or to its main actors; through reference to the same events as other texts; or through the reappearance of a text's main arguments in another text as well as certain syntactic (grammatical) and also rhetorical schemes and other tropes. The second important process is labeled 'recontextualisation'. By taking an argument, a topic, a genre, or a discursive practice out of context and restating/realising it in a new context, we first observe the process of de-contextualisation, and then, when the respective

$27 \quad$ Van Dijk (1991), p. 113

28 Reisigl, Wodak (2009), p. 89. 
element is implemented in a new context, of recontextualisation. The element then acquires a new meaning, because meanings are formed in use.

Conceptually, the empirical event under investigation is viewed as a phenomenon that has discursive manifestations across four heuristic levels of context (see Table 5.1. below). ${ }^{29}$

TABLE 5.1 Four-level Context-Model

1. The immediate text of the communicative event in question (a particular detailed transcript of talk; a specific newspaper article; a specific speech);

2. The intertextual and interdiscursive relationship between utterances, texts, genres and discourses (e.g. conversations with the same participants in different settings);

3. The extra linguistic social (e.g. physical gestures, facial expressions, postures, etc.) and environmental (e.g. room size and layout) variables and institutional frames (e.g. latent or formal hierarchical structure, informal power relations in a friendship, cultural constraints and conventions, etc.) of a specific 'context of situation';

4. The broader socio-political and historical context which discursive practices are embedded in and related to (e.g., knowledge derived from ethnography, study of the relationships in, and aspects of, the broader social and cultural macro-environment over time that influence the text, talk and conversations).

\section{4. $\quad$ Case Study: Recontextualising the 'Volk' and the 'Volkskörper'}

The core notions of the study, as in previous work, are

1. the interdiscursively related construction of the so-called Homo Austriacus/Homo Externus,

2. the narration and construction of a shared political past,

3. a shared culture,

4. a shared political present and future, and

5. the discursive construction of a "national body".30

\footnotetext{
29 See Wodak (2011).

3o See for example Wodak et al. (2009).
} 
The integration of the first and fifth categories - the Homo Austriacus and the national body - characterise the discourse of the far- and extreme right in Austria, becoming the focal point of discursive practices and argumentative patterns, serving related constructions of 'us' versus 'them'. Such constructions emphasise national uniqueness and (inner) homogeneity and downplay heterogeneity and difference within the population. Simultaneously, they also focus on differences to members of other nations, often resorting to stereotyping and singularisation. Here, I present some extreme right elements within the far right. Indeed, the Austrian Freedom Party (FPÖ) must be distinguished from other far-right populist parties not only in some of its ideological positions, but in terms of its history and ties to National Socialism. ${ }^{31}$

The national body is constructed in terms of a nation's territory, its 'natural' landscape as well as its built environment (e.g., architecture, sites and material art), its institutions (e.g., executive, legislative, judiciary) and its national 'heroes' (in, e.g., politics, the military, sports or arts). Previous studies have linked constructions of the national body to the symbols and practices of 'banal nationalism' as identified by Michael Billig:32 Abstract and seemingly apolitical, naturalised figurations of the nation lend themselves particularly well to everyday nationalisms. At this point, the link between the national body (i.e., its salient constructions in banal nationalism) and the construction of a Homo Nationalis should be explored in more detail, in particular the gender and body politics. It is here that the traditional extreme-right imaginary of the 'Volk', imagined as ideal male and female bodies, their roles and relationships, is articulated most clearly. Below, I analyse continuities and changes of such extreme-right ideologies in the intertextual and interdiscursive relationships across genres and publics, most prominently in popular culture which recontextualises and propagates the far-right's ideal subject. To do so, I also analyse some of the backstage and frontstage performances of the contemporary far-right as well as the historical continuities with National Socialist rhetoric and imaginaries, while providing a cross-sectional analysis of the fields of politics (party politics, part-affiliated organisations and media) and popular culture (music).

$31 \quad$ Leading members of the party have been investigated for and convicted of activities such as denying the Holocaust, violating the Verbotsgesetz or Prohibition Act of 1947, which banned the Nazi Party and aimed to suppress any potential revival of Nazism. See e. g. Engel, Wodak (2013).

See Billig (1995). 


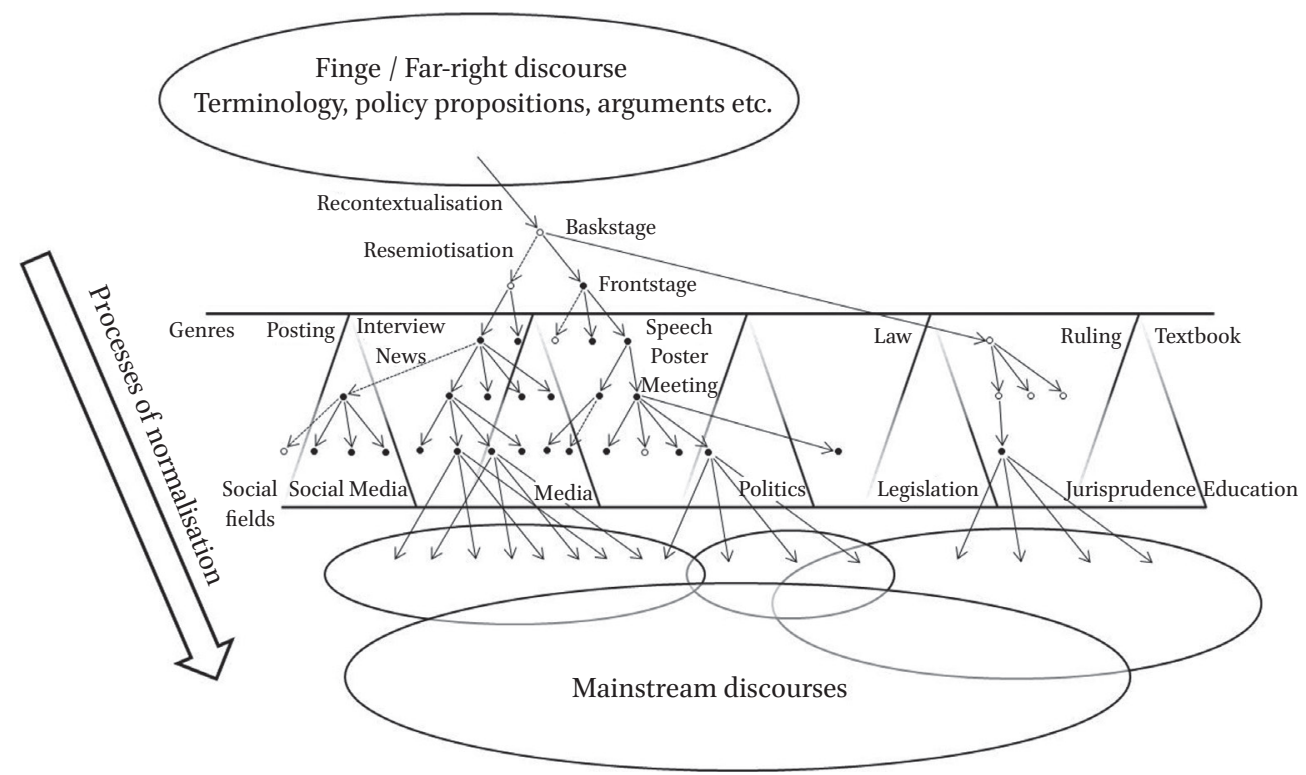

FIGURE 5.1 The normalisation of extreme-right ideology (adapted from Wodak 2019a, p.16)

Thus, one can trace continuities not only historically but across fields, showing how far-right and extreme right positions are recontextualised from closed-door meetings (i.e. backstage politics) as well as unofficial handbooks and pamphlets to election campaigns (posters, speeches, TV debates, i.e. frontstage politics) and ultimately normalised in popular culture. The advantage of such a cross-sectional approach is that it reveals the intertextual links between backstage and frontstage, i.e. the penetration of extreme-right ideology into everyday mainstream discourses as part of an ongoing process of normalisation. From the latter perspective, normalisation describes how ideologies are incorporated into the mainstream - not only of politics but of popular culture and other fields as well - through recontextualisations and resemiotisations, usually moving from backstage to frontstage, and across fields as well as genres.

\subsection{The Far- and Extreme Right in Austria: Tracing the History of the FPÖ}

The history of the FPÖ (Freiheitliche Partei Österreichs) dates back to the years after World War II and the political situation created by the four postwar Allied Powers until the 'Staatsvertrag' (State Treaty) of 1955. Between 1945 and 1955, the Allies supported the development of a bi-polar political scene by encouraging both the cooperation of socialist-democratic movements on the left and the formation of what would later evolve into the Social Democratic Party of Austria (sPÖ; Sozialdemokratische Partei Österreichs), and the merging 
of various conservative and pro-clerical movements into the Austrian People's Party (övp; Österreichische Volkspartei). Simultaneously, the forerunner of the FPÖ, the Association of Independents (VdU; Verband der Unabhängigen) was formed by incorporating political movements comprised of "old Nazis, German nationalists and a fair number of liberals", ${ }^{33}$ who were deliberately prevented from joining either of the two mainstream parties of the left and right.

In the 1949 parliamentary elections, the VdU won 12 per cent and soon called for "the abolition of all laws governing de-Nazification procedures". ${ }^{34}$ Their argument implied that the real victims were not those persecuted by the Nazi regime, but those who had profited by acquiring Jewish property and former members of the NSDAP. The VdU thus used a "grotesque conception of fascism [...] to attack the de-Nazification policies of the government and to equate Nazism with other political systems". ${ }^{35}$ Hence, the VdU allowed for a revival of Austrian pro-fascist sentiment and made it a significant element of the country's political makeup for coming years.

Following an internal crisis of the VdU, the FPÖ was established in 1955/56 "as a German nationalist party of the far right, in which former, seriously incriminated National Socialists took the leading functions". ${ }^{36}$ Indeed, the first FPÖ leader, Anton Reintaller, had been a high-ranking member of the Austrian NSDAP and the ss, but also held the position of Minister of Agriculture in the fascist Austrian government of Seyß-Inquart in 1938. All this made the FPö the successor to the Austrian NSDAP in all but its name. ${ }^{37}$

When Friedrich Peter (another former ss member) took over the FPÖ in 1958, the party's agenda did not change significantly. However, throughout the 1960s, the drive to moderate the FPÖ could be observed when both liberal and national views were given a voice. In 1970, the newly elected Chancellor Bruno Kreisky (sPö) formed a minority government with the support of the FPÖ and - to the dismay of many and in spite of strong opposition from within his own party - appointed four former NSDAP members to ministerial posts. This confirmed the FPÖ's participation in mainstream Austrian politics, signalling "that the sPÖ, to gain power, could do business with former Nazis in a pragmatic way".38 In 1986, the FPö's national convention witnessed a coup led by

Schiedel, Neugebauer (2002), p. 16; see Rheindorf, Wodak (2019) for an extensive overview of the FPÖ's history.

Manoschek (2002), p. 7 .

35 Schiedel, Neugebauer (2002), p. 16.

$36 \quad$ Manoschek (2002), p. 6.

37 Manoschek (2002), p. 7 .

38 Wodak et al. (1990), p. 290. 
Jörg Haider, who became the new chairman of the party. Haider's rise marked the turn of the majority of the FPÖ to radical and nationalist/nativist views. Employing strongly antisemitic, anti-foreigner and revisionist slogans, Haider led the FPö to successful elections at all levels. In the national election of 1999, the FPÖ received $26.91 \%$ and, for the first time in its history, took second place. After relatively brief negotiations, the FPÖ signed a coalition agreement with the övp (which had achieved third place) and entered the federal government in early 2000. This was the first time a far-right populist party came to power in an EU member state.

Although sanctions against the Austrian government were eventually introduced by the 14 other EU member states, it was not this external pressure but the controversial performance of the ÖVP-FPÖ government which pushed the FPö into gradual decline. At the next parliamentary elections on 1 October 2006, the FPÖ (headed by Heinz-Christian Strache, a former confidante of Haider) and the Bündnis Zukunft Österreich (Bzö, a splinter group headed by Haider) managed a combined $15.1 \%$. Thus, after six years in government, the FPÖ returned to its oppositional role until the FPÖ again formed a coalition government with the ÖVP on 19 December 2017 after the national election on 11 October 2017, where they achieved third place with $26 \%$ of the votes.

\subsection{The Backstage: Programmatic Utterances and Party Programs ${ }^{39}$}

No public figure represents extreme-right ideology within the FPÖ better than Johann Gudenus, former head of the FPÖ's Vienna chapter and the FPÖ's former party whip in parliament (2018-2019). Gudenus studied law in Vienna and Russian in Moscow, and completed an MA at the Diplomatic Academy of Vienna. He opposed the EU's sanctions against Russia, and held a sceptical stance towards the EU. Gudenus (whose father was convicted of Holocaust denial) is well-known for his explicit racist, nativist, antisemitic and homophobic utterances on the backstage of the party's activities which have frequently been leaked to the press and caused multiple scandals. ${ }^{40}$

Addressing closed publics, Gudenus has often voiced extreme right positions in surprisingly explicit terms. This has included, for example, racial policies for the so-called 'purity of Europe': "Europe is the cradle of the white race. We demand a Europe-wide, coordinated policy for the family and reproduction,

39 See Rheindorf, Wodak (2019) for more details of the FPö's gender, identity and body politics and its success in penetrating popular culture.

40 See Pollak (2015); Wodak (2019a). After the so-called 'Ibiza-Scandal', Gudenus was excluded from the FPÖ (see Wodak 2020 for details). 
including a commitment to the fact that Europe is white." ${ }^{31}$ It also included defamation of political opponents with antisemitic slurs: "If you mix red and green together, you get yellow. And yellow is the colour of Judas, it is the colour of treachery." ${ }^{2}$ And it included a clear denial of basic human rights ("Asylum is not a human right"), ${ }^{43}$ as well as homophobic, conspiracy theory-based projections of a doomed nation: "The powerful European lobby of homosexuals wants absolute equality for homosexuals and lesbians. It is hard to imagine where all this will lead." 44 Due to his former high-ranking position and frequent appearances in television debates and interviews, Gudenus' more public performances directly recontextualised backstage agenda into frontstage policies.

Gudenus' utterances bear a strong similarity to the party-affiliated publication Für ein freies Österreich [For a Free Austria], written by Michael Howanietz, a local FPÖ politician. ${ }^{45}$ Albeit not officially party doctrine, the book also closely mirrors the Handbuch freiheitlicher Politik [Handbook of FPÖ Politics], drafted by the party leadership to serve as an internal guideline for party functionaries regarding key policy areas. The focus here is - just very briefly - on the former publication as it constitutes a less constrained articulation of far-right and extreme-right ideologies, free of the rhetorical limitations that even the FPÖ, as an established party, should follow according to post-war conventions.

As Für ein freies Österreich is accompanied by endorsing forewords written by then FPÖ's chairman, Hans-Christian Strache, and current chairman, Norbert Hofer who stood as candidate for Austrian President in 2016 and was minister for infrastructure and transport in the coalition government (2018-2019), it is obvious that the party leadership agreed with the ideologies propagated in

41 Tangente 3/2004, magazine of the FPö's youth organisation "Ring Freiheitlicher Jugend" under chairman Johann Gudenus. This and all subsequent translations by Markus Rheindorf and Ruth Wodak. See Rheindorf, Wodak (2019) for more examples, a comprehensive overview and in-depth analysis.

Johann Gudenus at a rally in 2011, reported by the FPö's newspaper Neue Freie Zeitung, 27.10.2011, p. 8. See report and analysis, available on-line at https://www.stopptdierechten. at/2011/10/31/gudenus-und-die-farbe-des-judas/ [accessed 26.04.2019].

Johann Gudenus, press release on 19.12.2014, available online at www.ots.at/presseaussendung/OTS_20141219_OTSoo76 [accessed 01.07.2017].

44 Johann Gudenus in a speech given in Moscow on 11 September 2014. See report in the weekly Profil, 13 September 2014, available on-line at https:/www.profil.at/oesterreich/ fpoe-moskau-gudenus-eu-usa-nato-homosexuellenlobby-377959 [accessed 26.04.2019], and the interview with Johann Gudenus after his return from Moscow in the broadsheet Kurier, 19 September 2014 [accessed 26.04.2019].

See Rheindorf, Wodak (2019). 
this text. However, on frontstage (see below), these ideologies and statements are backgrounded. Indeed, after the Austrian national election on 15 October 2017 and the establishment of a coalition government between Sebastian Kurz' Neue öVP and the FPö, Hans-Christian Strache attempted to perform a soft version of the FPÖ's programmatic elements, via indirect and coded language as well as by denial of past explicit discriminatory utterances and propositions. However, this attempt frequently failed as the many breaches of taboos (in respect to Nazism, antisemitism, homophobia, and so forth) illustrate. ${ }^{46}$

In sum, the programmatic text (which has been extensively analysed elsewhere $)^{47}$ defines itself as a call for "an autonomous, independent country ", i.e. independent of transnational organisations, international law, international economy, the exchange of goods, which are all listed as ways in which Austria is being controlled by others. ${ }^{48}$ Significantly, the various argumentative strands of the book - all ultimately intended to save Austria from an alleged immanent doom - are linked to the extreme-right's ideologies and discursive constructions of the national body and related nativist body politics. ${ }^{49}$ In this way, the book calls for "an independent country that depends on its many existent strengths, its nature, its infrastructure and the productive power of its people".50

In the apocalyptic worldview propagated throughout the book, migrants are perceived as a threat precisely because they allegedly possess stronger identities: Their "assault" or slow invasion to "demographically displace" the Austrian people makes the latter "a species on the brink of extinction".51 The gravest threat to the nation, however, is identified in an imagined decaying national pride: Honour and loyalty to the community of the nation are the foundation for loyalty and faithfulness in the heterosexual relationship. ${ }^{52}$

In this way, the ultimate Feindbild emerges: women and men who have adopted new life styles and gender roles - integrating new family patterns, mobility, diversity, career, and shared child care. White male patriarchy is perceived as being under threat, simultaneously endangered by the alleged invasion of the so-called 'cultural other'.

\footnotetext{
$46 \quad$ See Wodak (2018); Wodak (2019b).

47 See Rheindorf, Wodak (2019).

48 See Howanietz (2013), p. 6.

49 See e. g. Musolff (2010); Wodak (2015a).

50 Howanietz (2013), p. 7 .

$5^{1} \quad$ Howanietz (2013), p. $19 f$.

$5^{2}$ Howanietz (2013), p. 31. "Ehre" and "Treue", the two concepts the book praises in this context, formed the core of the ss motto "Meine Ehre heißt Treue", which is banned under the Austrian Verbotsgesetz. See Engel, Wodak (2013).
} 
Comparing this inner weakness to the external threat identified as migrants, the book finally offers two alternative options for the future: The "true" Austrian "Volk" will, the FPÖ argues, employing the typical and traditional racist discourse about parasites, either slowly degenerate and die off, "eaten from the inside like wasp larvae eat maggots"; 53 or current developments will lead to a violent "civil war",54 thus triggering fear and anxiety. The danger scenarios are manifold; uncertainty, fear, and anger are produced and reproduced, and fallacious arguments are provided as legitimation. The author clearly prefers the latter, arguing that like any conflict it would be "productive" and "awaken potential". ${ }^{55}$ Either way, he concludes, "Europe will burn."56

\subsection{Frontstage: The Extreme Right in Election Campaigns}

Since Heinz-Christian Strache took control of the FPÖ in 2005, frontstage activities of the party - particularly in election campaigns and social media - have seen an obvious and clear increase of banal nationalism: displaying the Austrian flag, singing the national anthem, and showing an abundance of other symbols of national pride.

As argued by Forchtner et al., the manifold patterns of media communication and the clever and ubiquitous appropriation of media agenda and frames employed in the recent success of populist-right and extreme-right parties cannot be dismissed or marginalised as a mere coincidence. ${ }^{57}$ As Bos, van der Brug \& de Vreese illustrate, successful far-right populist leaders have actually managed to achieve a delicate balance between, on the one hand, appearing innovative and anti-establishment, and, on the other, authoritative and legitimate; thus they counter the élites but do not oppose the liberal democratic system per se. ${ }^{58}$ Frequently, this is achieved by scandalisation and the intentionally and continuously provoked dynamic of the so-called far-right populist perpetuum mobile, ${ }^{59}$ or by what labels as "dramatisation", i.e., "the need to generate tension in order to build up support for the party [...] by denouncing the tragedies that would befall the community if it were to be deprived of its defenses". 60

\footnotetext{
$53 \quad$ Howanietz (2013), p. 117.

54 Howanietz (2013), p. 121.

55 Howanietz (2013), p. 113.

$56 \quad$ Howanietz (2013), p. 134.

57 See Forchtner et al. (2013).

$5^{8}$ See Bos, van der Brug, de Vreese (2011).

59 See Wodak (2013a); Wodak (2013b); Wodak (2015a), p. 19f; Wodak (2020), p. 25f.

6o Albertazzi (2007), p. 335.
} 
Scandalisation also implies manifold references to the allegedly charismatic leaders of such parties, who construct themselves as saviours, problem solvers and crisis managers, which may lead voters to have more confidence in the effectiveness of the politics of the populist far-right. The way the tension between extraordinariness and being 'one of us', i.e., being 'authentic', was cleverly managed by former F PÖ leader Jörg Haider on front stage and further developed by his successor, HC Strache (as he was branded) in many different publics and genres, ${ }^{61}$ from TV interviews to snippets caught on video while dancing in a disco, from pamphlets and manifestos to posters and comic booklets, all of which are accessible on HC Strache's homepage ${ }^{62}$ and disseminated via Facebook. 63

Indeed, the FPÖ maintains its Web presence via the main party web page (www.fpoe.at) and a party-related think-tank (www.fpoe-bildungsinstitut.at). Members of the FPÖ also operate a blog called "Uncensored" (www.unzensuriert. at) ${ }^{64}$ and an official YouTube channel (www.youtube.com/ Oesterreichzuerst) called "Austria First", a name employed in many campaigns and major referenda undertaken by the party in both the 1990s and 20oos. The YouTube Channel utilizes a variety of genres, ranging from recordings of HC Strache's speeches and interviews to his rap-songs (see below) and different election-campaign spots and short films. Before his exclusion from the F PÖ in November 2019, the party also managed the Web presence of its leader - via his Web page (www. hc-strache.at) as well as channels on Facebook (www.facebook.com/HCStraa che?ref=mf) and Flickr (www.flickr.com/search/?q=strache\&w=all) - after Strad che's exclusion from the FPÖ, his homepage was closed down.

Following Alexander, the symbolic dimension of 'doing politics' must be understood as central to all efforts of a politician's performance, in the media, at election rallies, in parliament, at press conferences, and so forth. ${ }^{65}$ Alexander

$61 \quad$ See Forchtner et al. (2013); Wodak (2011) as well as Wodak, Forchtner (2018) for more details on the fictionalisation of politics.

62 See http://www.hcstrache.at/home/ [accessed 02.05.2017].

63 See Köhler, Wodak (2012); Wodak, Köhler (2010); Wodak (2013a); Wodak (2013b); Wodak (2020) for recent detailed studies and research on the FPö's and HC Strache's media policies as well as on his downfall and exclusion from the FPÖ in November 2019.

64 The blog - there is now also a print edition - was initiated by Martin Graf, a member of a far-right fraternity and former third president of the Austrian parliament. According to the Austrian chamber of commerce. See http://www.wkoecg.at/Web/Ecg.aspx?FirS maID=of68efff-25b9-46cd-gedd-b18a79agb92d [accessed 22.10.2012], it is now managed by Walter Asperl, who was also Graf's office manager during his time in parliament as third president of the chamber.

65 See Alexander (2006); Forchtner et al. (2013); Wodak (2020), pp. 188-92. 
also argues that these performances must hook into the background culture, symbols, narratives and myths of the respective society to be successful. In other words: If such symbolic practices are supposed to resonate, they should draw on, and mobilize, a common cultural structure, via appeals to common knowledge of epistemic communities, to the endoxa by using presuppositions, insinuations and other pragmatic devices as well as specific argumentation schemes. As Tannen succinctly notes in her best-selling book The Argument Culture, "fitting ideas into a particular camp requires you to oversimplify them. Again, disinformation and distortion can result. Less knowledge is gained, not more. And time spent attacking an opponent or defending against attacks is not spent doing something else".66 It is thus certainly legitimate to ask at this point what kind of specific performativity characterizes far-right populist politicians differently than politicians per se.

The form of the performance is only one - even if important - part of the specific far-right populist habitus. Form and content are necessarily linked to construct the specific political agenda. In such populist rhetoric, several elements are thus combined: specific topics which are addressed; specific ideologies which feed into and constitute utterances and performances; strategies of calculated ambivalence and provocation which are used to create and deescalate intentionally provoked scandals; and a continuous campaigning style, an overall antagonistic habitus which does not comply with hitherto conventional rules of negotiation and compromise. ${ }^{67}$

The many positionings of HC Strache constructed a multi-faceted politicians' identity, oriented towards some and excluding others: as saviour of the Occident; as casual, smiling but also serious statesman; as fighter; as attractive young man; as extreme right-wing fraternity member with paramilitary experience; and as hero, revolutionary and superman, surrounded by loyal supporters, cheerleaders, body guards, and smiling young men and women. ${ }^{68}$ In this way, one could reiterate that Strache - like his predecessor Haider before him - had been a "man of all seasons", ${ }^{69}$ adaptable to the needs and desires of ordinary people, bonding with them as well as representing them. The party, through all of this, had been metonymically identified with him and his agenda, consisting mainly of anti-immigration policies, anti-EU agenda and nativist nationalism as well as explicit insinuations of Nazi ideology and a revisionist conception of Austria's (and Germany's) history.

\footnotetext{
66 Tannen (1998), p. 289.

$67 \quad$ See Forchtner et al. (2013).

68 Analyzed in more detail in Wodak (2015a), pp. 136-141.

69 See Gingrich (2002).
} 


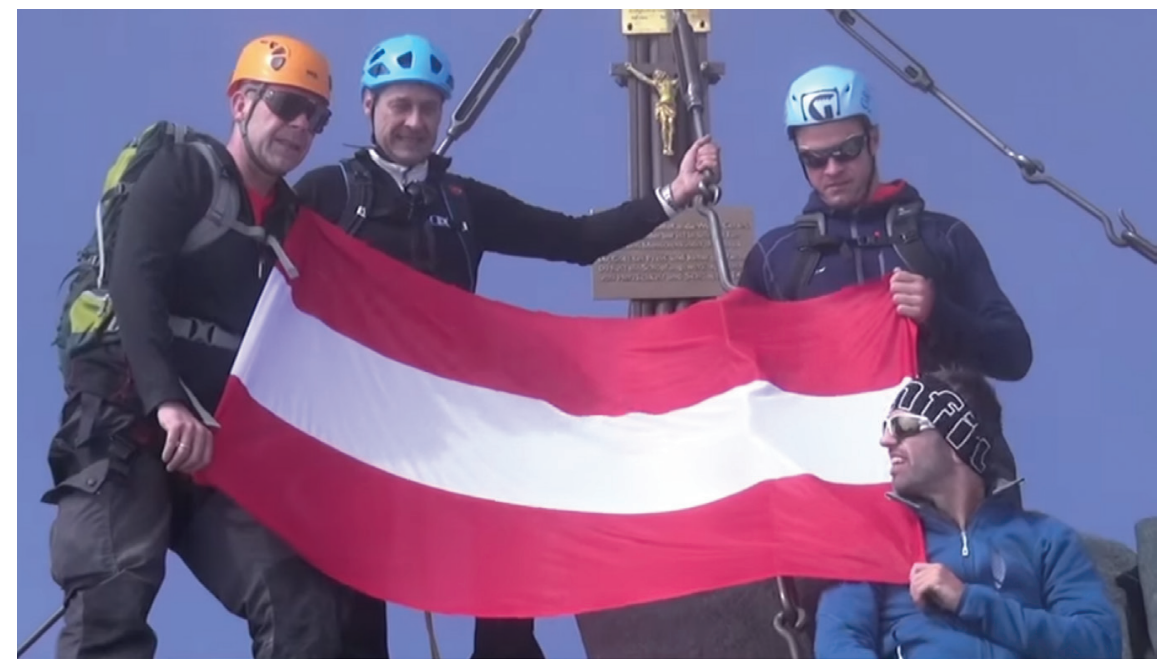

FIGURE 5.2 Vilimsky (MEP), Strache, Gudenus and Kickl (Party Secretary) brandishing the Austrian flag at the Großglockner peak (Austria's highest mountain)

In terms of national identity, the symbols which had been used by the Strache-FPÖ are linked to deeply conservative constructions of the national body, e.g. rural landscapes, snow-covered mountain tops, traditional agriculture and farmers, religious symbols of Christianity. In many images and aspects, the respective texts and performances feature Strache himself enacting and employing these symbols (see Figure 5.1).

Since these are symbols of the nation rather than the party, their recontextualisation and resemiotisation by the FPÖ continue to constitute a provocative appropriation linked to the FPÖ's claim to be the only party to represent 'the people' and the nation or 'Heimat'. Indeed, ever since Strache's leadership one is confronted with a re-branding of the FPÖ as the "Soziale Heimatpartei", the Social Homeland Party (a label it shares with the extreme-right NPD of Germany).

Two such provocations relate to Austria's national anthem: firstly, publicly refusing to sing the amended national anthem (since 2011, the lyrics include "daughters" alongside "sons"), thus breaking the respective relevant law, and secondly, using an alternative anthem for their campaigns, titled "Immer wieder Österreich". The lyrics of this song incorporate the well-known chorus of soccer fans at games of Austria's national team - "Immer wieder, immer wieder, immer wieder Österreich" "Time and again, time and again, time and again Austria") - but also appeal to the "honesty, righteousness and loyalty" of all true Austrians and call on them to "pledge" their loyalty to "their country". The accompanying video resemiotises the lyrics of the actual Austrian anthem and alludes to the aesthetics of Nazi era films such as Leni Riefenstahl's work (see 


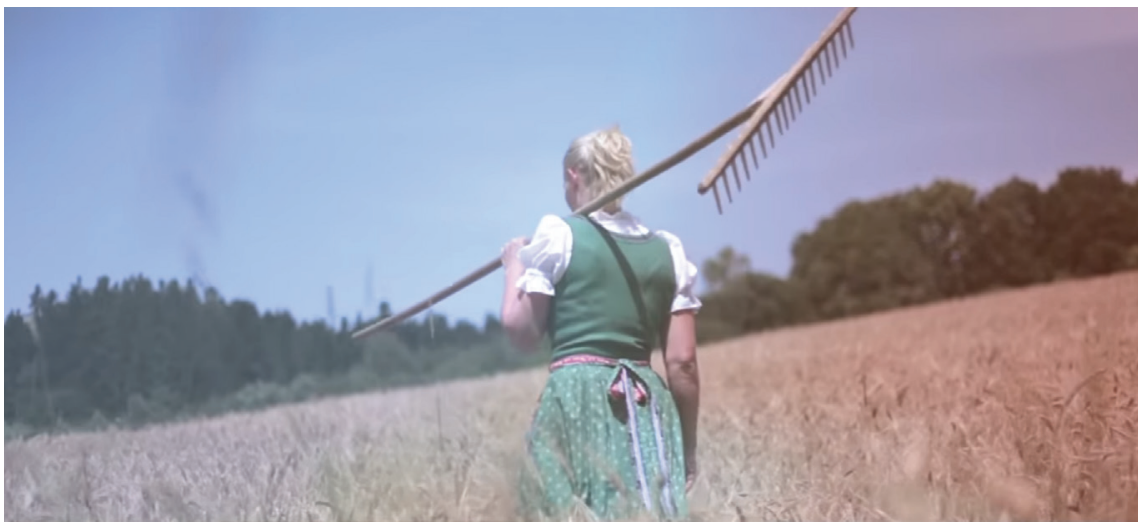

FIGURE 5.3 Still from the FPÖ's alternative anthem and election campaign video

Figure 5.2). Such discursive strategies of anthropomorphising, culturalising and ethnicising the national body go back many years. Indeed, the frontstage politics of the far-right in Austria are eminently culturalist and biologist. ${ }^{70}$

The dynamics of everyday performances frequently transcend careful analytic categorisations; boundaries between categories are blurred and flexible, open to change and to ever new socio-economic developments. In sum, when analysing far-right (or, indeed, left-wing) populist movements and their rhetoric, it is essential to recognize that their propaganda - realised as it is in many genres across relevant social domains - always combines and integrates form and content, targets specific audiences and adapts to specific contexts. Only by doing so, are we able to deconstruct, understand and explain their messages, the resonance of their slogans and their electoral success.

In the body and social politics of such ideologies, the 'national family' must preserve the traditional paternalistic order of the sexes and maintain the nation's body as white and pure. This draws on conservative and fascist imaginaries as extensively investigated by Musolff and Richardson in their research on the concept of the 'Volk' and the 'Volkskörper' across German and British nationalistic writing since the eighteenth century. ${ }^{71}$ In summary, the extreme-right's salient construction of the national body and use of associated

$70 \quad$ See Krzyżanowski, Wodak (2009); Wodak, Köhler (2010); Rheindorf, Wodak (2019).

71 See Musolff (2010); Richardson (2017). 
symbols shows a constant effort to mobilize feelings of national pride but equally of national emergency, of threat and danger, of the possible decay of the Western World.

Finally, it must be emphasised that the FPÖ as the only established party in Austria which has consistently provided a home for extreme-right positions is far from homogenous. The ideological positions articulated by its leading figures range from extreme-right and pan-German nationalism to toned-down positions, particularly on the frontstage. Indeed, the ability to alternate between 'strong' and 'soft' performances according to context and audience is a defining characteristic of the contemporary far right in Austria. Both allusions to and encoded references to extreme-right and Nazi ideologies are thus part of the strategy of calculated ambivalence that ensures deniability. Closely related to these strategic performances are processes of normalisation, transcending and breaking taboos through recontextualisation and resemiotisation as aspects of extreme-right imaginaries, moving from backstage to frontstage and from party politics to the mainstream.

Such normalisation processes became highly evident in the Austrian national election 2017 where the Austrian People's Party under its new leader Sebastian Kurz appropriated far-right agendas in respect to migration and asylum issues, thus normalising important elements of the FPÖ's far-right program. This strategic, cleverly designed and marketised election campaign illustrates well how normalising procedures were employed in many genres and across social and political fields, on national, regional, and local levels. ${ }^{72}$ In addition, the governing ÖVP (in its coalitions with both the FPÖ until 2019 and with the Green Party since 2020) has implemented its own version of 'message control'73 which supports top-down normalisation: Each week, a specific topic is launched in a press conference and elaborated on for one week, until being replaced with a new agenda seven days later. For example, while discontent and strikes were contemplated against a new law allowing for 12-hour working days and 6o-hour working weeks if employees voluntarily comply with their employer's request (implemented with 1 September 2018), the government launched various news items about a ban of headscarves for Muslim girls in kindergarten and pre-school. In this way, the government pleased their electorate with anti-Muslim and anti-immigration agendas, while being aware that the core electorate of the FPÖ would be enraged by such new labour laws, which were upsetting the post-war consensus of the social welfare state.

72 See Wodak et al. (2020) for details.

73 John, Mittelstaedt (2018). 
The media have thus been kept busy debating 'the headscarf', while being distracted from other relevant news stories.

As noted by Uitz ${ }^{74}$ of Orbán's Hungary, parliamentary procedures are also frequently neglected since 2018. Discussion and consultations with experts, the opposition, and journalists seem to be out of the question in Kurz's Austria ${ }^{75}$. In sum, it seems that the new Austrian People's Party (ÖVP) - in its streamlined trajectory to power (at least in the sense of leading coalition governments since 2018) - has either ignored or quietly accepted some non-democratic practices, thus normalising the previously unsayable and unacceptable.

\section{Bibliography}

Adorno, Theodor (1966). Negative Dialektik (Frankfurt a.M.: Suhrkamp).

Albertazzi, Daniele (2007). 'Addressing "the People". A Comparative Study of the Lega Nord's and Lega dei Ticinesi's Political Rhetoric and Style of Propaganda', Modern Italy, 12.3, pp. 327-347.

Alexander, Jeffrey C. (2006). The Civil Sphere (Oxford: Oxford University Press).

Anderson, Benedict ([1985] 1995). Imagined Communities. Reflections on the Origin and Spread of Nationalism (London: Verso).

Berger, Ernst, Ruth Wodak (eds) (2018). Kinder der Rückkehr. Geschichte einer marginalisierten Jugend (Berlin: Springer).

Billig, Michael (1995). Banal Nationalism (London: Sage).

Blackledge, Adrian (2009). Discourse and power in a multilingual world (Amsterdam: Benjamins).

Bos, Linda, Wouter van der Brug, Claes H. de Vreese (2011). 'How the Media Shape Perceptions of Right-Wing Populist Leaders', Political Communication, 28.2, pp. 182-206.

Boukala, Salomi (2013). The Greek Media Discourse and the construction of European Identity. Islam as Radical Otherness, collective identity and 'Fortress Europe' (Ph.D. Thesis: Lancaster University).

Bourdieu, Pierre (1990). The Logic of Practice (Cambridge: Polity Press).

Bourdieu, Pierre (1994). 'Rethinking the State. Genesis and Structure of the Bureaucratic Field', Sociological Theory, 12.1, pp. 1-18.

Breuss, Susanne, Karin Liebhart, Andreas Pribersky (1995). Inszenierungen. Stichwörter zu Österreich. (Wien: Sonderzahl).

$74 \quad$ Uitz (2015).

75 See Wodak (2019a); Wodak (2019b) for details and a comprehensive analysis of developments in Austria since 2018. 
De Cleen, Benjamin (2012). The rhetoric of the Flemish populist radical right party Vlaams Blok/Belang in a context of discursive struggle. A discourse-theoretical analysis (Ph.D. Thesis: Vrije Universiteit Brussels).

Delanty, Gerard, Krishan Kumar (2006). 'Introduction', in Gerard Delanty, Krishan Kumar (eds), The Sage Handbook of Nations and Nationalism (London: Sage), pp 1-4.

Engel, Jakob, Ruth Wodak (2013). "Calculated Ambivalence” and Holocaust Denial in Austria', in Ruth Wodak, John E. Richardson (eds) Analysing Fascist Discourse. European Fascism in Talk and Text (London: Routledge), pp. 73-96.

Forchtner, Bernhard, Michal Krzyżanowski, Ruth Wodak (2013). 'Mediatisation, RightWing Populism and Political Campaigning. The Case of the Austrian Freedom Party (FPÖ)', in Mats Ekström, Andrew Tolson (eds), Media Talk and Political Elections in Europe and America (Basingstoke: Palgrave), pp. 205-228.

Frindte, Wolfgang, Nico Dietrich (eds) (2017). Muslime, Flüchtlinge und Pegida. Sozialpsychologische und Kommunikationswissenschaftliche Studien in Zeiten globaler Bedrohungen (Wiesbaden: Springer).

Gellner, Ernest (1983). Nations and Nationalism (Oxford: Blackwell).

Gingrich, Andre (2002). 'A Man for all Seasons. An Anthropological Perspective on Public Representations and Cultural Politics of the Austrian Freedom Party', in Ruth Wodak, Anton Pelinka (eds), The Haider Phenomenon in Austria (New Brunswick: Transaction Press), pp. 87-102.

Griffin, Roger (1999). 'Afterword. Last Rights?', in Sabrina P. Ramet (ed.), The Radical Right in Central and Eastern Europe since 1989 (Pennsylvania: Penn State Univ. Press), pp. 297-321.

Halbwachs, Maurice (1967). Das kollektive Gedächtnis (Stuttgart: Enke).

Hall, Stuart (ed.) (1996). Questions of cultural identity (London: Sage).

Haller, Max et. al. (eds) (1996). Identität und Nationalstolz der Österreicher. Gesellschaftliche Ursachen und Funktionen - Herausbildung und Transformation seit 1945 - Internationaler Vergleich. (Wien: Böhlau).

Howanietz, Michael (2013). Für ein freies Österreich. Souveränität als Zukunftsmodell (Wien: Freiheitlicher Parlamentsklub).

John, Gerhard, Katharina Mittelstaedt (2018). ,Wie Türkis-Blau Widersprüche wegredet', Der Standard, 28 February, available on-line at https://derstandard.at/ 2000075143822/Wie-Tuerkis-Blau-Widersprueche-wegredet [accessed 26.04.2019].

Köhler, Katharina, Ruth Wodak (2012). 'Mitbürger, Fremde und "echte Wiener" - Einund Ausgrenzungen über Sprache. Diskursive Konstruktion von Macht und Ungleichheit am Beispiel des Wiener Wahlkampfes 2010', Deutschunterricht, 6.11, pp. 64-74.

Krzyżanowski, Michal (2010). The discursive construction of European identities. A multi-level approach to discourse and identity in the transforming European Union (Frankfurt a.M.: Lang). 
Krzyżanowski, Michal, Ruth Wodak (2009). The Politics of Exclusion. Debating Migration in Austria. (New Jersey: Transaction Publishers).

Manoschek, Walter (2002). 'FPÖ, ÖVP and Austria's Nazi Past', in Ruth Wodak, Anton Pelinka (eds), The Haider Phenomenon in Austria (New Orleans: Transaction Press), pp. $3^{-16 .}$

Mudde, Cas (2007). The Populist Radical Right Parties in Europe (Cambridge: Cambridge University Press).

Musolff, Andreas (2010). Metaphor, Nation, and the Holocaust (London: Routledge).

Pollak, Alexander (2015). Der Hassprediger. Der aufhaltsame Aufstieg des Johann G. Ein Beipacktext zur Wiener Wahl (Wien: Czernin).

Rathkolb, Oliver (2011). Die paradoxe Republik (Innsbruck, Wien: Haymon-Verlag).

Reisigl, Martin, Ruth Wodak (2009). 'The Discourse-historical Approach (DHA)', in Ruth Wodak, Michael Meyer (eds) (20o9). Methods of Critical Discourse Analysis (London: Sage), pp. 87-121.

Reisigl, Martin, Ruth Wodak (2001). Discourse and Discrimination. Rhetorics of Racism and Antisemitism (London: Routledge).

Rheindorf, Markus, Ruth Wodak (2018). 'Borders, Fences and Limits. Protecting Austria from Refugees. Metadiscursive negotiation of meaning in the current refugee crisis', Journal of Immigrant \& Refugee Studies. https://www.tandfonline.com/doi/full/10.1 o8०/15562948.2017.1302032 [accessed 12.01.2019].

Rheindorf, Markus, Ruth Wodak (2019). “Austria First” Revisited. A diachronic cross-sectional analysis of the gender and body politics of the extreme right', Patterns of Prejudice, 53.3, special issue, ed. by Bernhard Forchtner, Christopher Kolvraa, pp. 302-320.

Ricento, Thomas (2003). 'The Discursive Construction of Americanism', Discourse \& Society, 14.5 , pp. $611-637$.

Richardson, John E. (2017). 'Fascist Discourse', in John Flowerdew, John E. Richardson (eds), The Routledge Handbook of Critical Discourse Studies (London: Routledge), pp. 447-462.

Schiedel, Heribert, Wolfgang Neugebauer (2002). 'Jörg Haider, die FPÖ und der Antisemitismus', in Anton Pelinka, Ruth Wodak (eds), "Dreck am Stecken". Politik der Ausgrenzung (Wien: Czernin), pp. 11-31.

Sicurella, Federico Giulio (2015). Speaking for the Nation. A critical discourse study of intellectuals and nationalism in the post-Yugoslav context (Ph.D. Thesis: Lancaster University).

Skenderovic, Damir (2009). The Radical Right in Switzerland. Continuity and Change 1945-2000 (New York: Berghahn Books).

Tannen, Deborah (1998). The Argument Culture. Moving from Debate to Dialogue (New York: Random House).

Uitz, Renate (2015). 'Can you tell when an illiberal democracy is in the making? An appeal to comparative constitutional scholarship from Hungary', I.Con, 13.1, pp. 279-30o. 
Van Dijk, Teun A. (1991). News as Discourse (New York: Erlbaum).

Walton, Douglas ([1970] 1996). Argumentation Schemes for Presumptive Reasoning (New Jersey: Erlbaum).

Wodak, Ruth ([2009] 2011). The Discourse of Politics in Action. Politics as Usual (Basingstoke: Palgrave).

Wodak, Ruth (2013a). “Anything goes!” The Haiderization of Europe', in Ruth Wodak, Majid KhosraviNik, Brigitte Mral (eds), Right-Wing Populism in Europe. Populism and Discourse (London: Bloomsbury), pp. 23-38.

Wodak, Ruth (2013b). 'The strategy of discursive provocation - a discourse-historical analysis of the FPÖ's discriminatory rhetoric', in Matthew Feldman, Paul Jackson (eds), Doublespeak. The Rhetoric of the Far-Rights since 1945 (Frankfurt a.M.: ibidem), pp. 101-122.

Wodak, Ruth (2014). 'Political discourse analysis. Distinguishing frontstage and backstage contexts. A discourse-historical approach', in J. Flowerdew (ed.), Discourse in Context (London: Bloomsbury), pp. 321-45.

Wodak, Ruth (2015a). The Politics of Fear. What Right-wing Populist Discourses Mean (London: Sage).

Wodak, Ruth (2015b). "Normalisierung nach rechts". Politischer Diskurs im Spannungsfeld von Neoliberalismus, Populismus und kritischer Offentlichkeit', Linguistik Online, 73, 4-15.

Wodak, Ruth (2017). 'The Establishment, the Elites, and the People. Who's who?', Journal of Language and Politics, special issue, ed. by Ruth Wodak, Michal Krzyżanowski, pp. 1-15. DOI: 10.1075/jlp.1703o.wod.

Wodak, Ruth (2019a). 'The micro-politics of right-wing populism', in Gregor Fitzi, Jürgen Mackert, Bryan S. Turner (eds), Populism and the Crisis of Democracy (London: Routledge), pp. 11-29.

Wodak, Ruth (2019b). 'Entering the "Post-Shame era", The rise of illiberal democracy, populism and neo-authoritarianism in Europe. The case of the turquoise-blue government in Austria 2017/2018', Global Discourse, special issue, ed. by Russel Foster, Jan Grzymski, The Limits of Europe, doi.org/10.1332/204378919X15470487645420.

Wodak, Ruth (2020). The Politics of Fear. The shameless normalisation of far-right discourse. (London: Sage; 2nd revised and extended edition).

Wodak, Ruth, Bernhard Forchtner (2018). 'The Fictionalisation of Politics', in Ruth Wodak, Bernhard Forchtner (eds), Routledge Handbook of Language and Politics (London: Routledge), pp. 572-586.

Wodak, Ruth, Katharina Köhler (2010). 'Wer oder was ist "fremd"? Diskurshistorische Analyse fremdenfeindlicher Rhetorik in Österreich', Sozialwissenschaftliche Studien 1, pp. 33-55. 
Wodak, Ruth, Rudolf de Cillia, Markus Rheindorf, Sabine Lehner (2020). Österreichische Identitäten im Wandel. Empirische Untersuchungen zu ihrer diskursiven Konstruktion 1995-2015. (Berlin: Springer).

Wodak, Ruth, John E. Richardson (eds) (2013). Analysing Fascist Discourse. European Fascism in Talk and Text (London: Routledge).

Wodak, Ruth, Rudolf de Cillia, Martin Reisigl, Karin Liebhart ([1999] 2009). The discursive construction of national identities (Edinburgh: Edinburgh University Press. 2nd revised edn).

Wodak, Ruth, Peter Nowak, Johan Pelikan, Helmut Gruber, Rudolf de Cillia, Richard Mitten (1990). "Wir sind alle unschuldige Täter!" Diskurshistorische Studien zum Nachkriegsantisemitismus (Frankfurt a.M.: Suhrkamp). 
PART 3

Strategies of Othering 


\title{
The Camp and the Home
}

\section{Europe as Myth and Metaphor}

\author{
Joep Leerssen
}

\begin{abstract}
This contribution attempts to reduce the complexity of the manifold images of Europe's position in the world with the help of the imagological method. It outlines an evolving and progressively more entangled dialectics as a successively shrinking 'Europe' was opposed, either in negative or positive terms, to a growing lineage of Others. The process takes us from a large and open-bordered Europe in Classical Antiquity to a concentrated and more self-enclosed Northern-Eurozone Europe in its recent polarisation between postcolonial/post-totalitarian guilt and resurgent populist xenophobia. Throughout this long and complex history, the classical notion of the House (oikos, domus) has continued to inform European self-images. For better or worse, Europe sees itself in terms of its fundamental domesticity.
\end{abstract}

\section{Europe as Frame, Europe Framed}

How do we frame Europe? It is a key insight in imagology that the image of a given 'nation' is always conceived in a discourse of contrast, even if that contrast is elided or left implicit. To observe that the French are frivolous or that the English have a stiff upper lip, means, implicitly or explicitly, to observe how this attribute renders them different from the non-French or non-English. Nations are most characteristically themselves (so the assumption goes) in precisely those aspects in which they are most noticeably different from other nations. For imagologists, this means that our analysis of ethnotypes will always involve an unpacking of the implied contradistinctions, and to establish what Others are used as a background against which the reputed 'character' or 'identity' of a nation is silhouetted. ${ }^{1}$

1 On the theory and method of imagology, generally: Beller, Leerssen (2007); Dyserinck (2015); Leerssen (2016a) and the website www.imagologica.eu.

(C) JOEP LEERSSEN, 2021 | DOI:10.1163/9789004436107_008

This is an open access chapter distributed under the terms of the CC BY-NC-ND 4.0 license. 
If, then, an imagologist were to approach the vexed question of what constitutes a European 'identity' (a topic which has attracted inordinate amounts of punditry: hundreds of books and essays which invariably begin with intense hand-wringing on the utter impossibility of defining Europe), his/her first reflex would be to unpack the implied contrast-frame: a 'European identity' as opposed to what, precisely? As opposed to America, or Asia, or Africa? The resulting European ethnotype would take on very different characteristics in each of these contrast-frames: Europe-as-opposed-to-America would be a continent of mixed feelings, ironies, 'negative capability' and a weary, disenchanted refinement as opposed to American vigour, brashness and energetic naiveté. (Examples: Major Calloway vs. Holly Martins in The Third Man; Humbert Humbert vs. Lolita in Nabokov's novel.) Europe as opposed to Asia evokes connotations of historical development and civil society vs. the unchanging presence of pre-civic traditionalism and a propensity towards 'Oriental despotism'. Europe vs. Africa evokes different stereotypical frames again: self-imposed social order vs. the brute force of nature. And so 'Europe' can be framed, from case to case, as the continent of mixed feelings, civil society and social order; of Rembrandt and Captain Cook, Auschwitz and Chartres; scientific achievement and enervated decline; Augustine, Erasmus, Torquemada, Tolstoy, Mussolini and Derrida.

It is for that reason that the Imagology handbook, edited by Manfred Beller and myself, ${ }^{2}$ abstained from carrying an entry on, of all places, Europe. Imagology offers profiles of ethnotypes from 'Albanian' to 'Turkish'; it contains articles surveying eurocentric attitudes towards global regions from Africa to Polynesia. There is even an entry on 'Ethnocentrism and eurocentrism'; but an article on 'Europe' as such is lacking. Europe is, as it were, the hole in that book's donut. The omission was a deliberate one: Europe was, if anything, the implied contrast-frame against which all exoticisms listed in the book were silhouetted, and as such proved too complex, too shape-shifting, to be covered within the book's scope.

I have attempted to remedy that hollow core at the centre of imagology in a subsequent book (in Dutch), which in free-floating essayistic form tried to come to terms with the shape-shifts in the European self-image. ${ }^{3}$ Following on from that attempt I will in the following pages try to systematize some imagological insights and use them to throw light on the recent crises in Europe's self-positioning in the world.

2 See Beller, Leerssen (2007).

3 Leerssen (2016b). 
The imagologist's first reflex is to situate a given ethnotype in its implied contrast-frame: to set off a purported Identity against its implied Other. There is a curious correlation between the number of potential Others a given identity has and its hegemonic position in our discourse. The very fact that 'Europe' can be silhouetted against so many others is a sign of its central position in our discursive configuration of ethnotypes about the world (this is what made Europe the gravitational Black Hole at the galactic centre of the Imagology handbook.) Subaltern nationalities tend to have their ethnotype dominated by one overriding binary opposition. In the racial view of humankind à la Blumenbach, Black is defined vis-à-vis White; so is Red, or Yellow. But White has all three as its reservoir of potential Others. The Irish ethnotype tends to be wholly dominated by its contrastive pairing with 'English'; but Englishness can also be set off against Scottish, German, French etcetera.

The multiplicity of Others for an image of Europe is, then, a given which needs to be addressed and analysed. And so the imagologist's first reflex calls forth the immediate necessity of applying the method's second reflex: that of historicising.

Imagology is not a method in the social sciences but in the humanities, and as such its awareness of historical change is of categorical importance. Ethnotypes are part of a historical development and behind their short-term fixity and apparent rigidity we need to capture their long-term variability and changeability. The character-traits attributed to nations are presented to us as immutable anthropological fixities: Russians 'just are' predisposed to patient resignation, Italians are naturally ebullient, Swedes cerebral and introspective. But in practise the documentary evidence shows that for every stiff-upper-lipped English Phileas Fogg there is a violent, brawling Vin Jones, for every earthy French Gérard Depardieu there is a rigid, cartesian Michel Barnier, for every dreamy Irish Enya there is a tough-as-nails Bernadette Devlin, all of whom are considered equally 'representative' of their alleged 'national character'. In historicising those contradictory variations - setting out their manifestations in the documentary record along a time-line - we notice that the ethnotype available nowadays is the cumulative end result of a centuries-long historical dialectics, in which earlier ethnotypes, dominant in one period, had called forth their own contrary opposites. Much of the imagologist's work consists in analysing the superimposed strata of this ethnotypical sedimentation into the successive periods of its historical development.

I should point out in this context that the cultural history of ideas, unlike the social history of events, is cumulative rather than successive; it works by 
accretion rather than replacement. Later ideas do not replace or oust older ideas, but are superadded on top of them. The old remains available underneath the new. The Beatles do not abolish Bach, nor does the recent 'sociopathic murderer' ethnotype of 'nordic noir' crime thrillers abolish the earlier Scandinavian ethnotypes of serene reasonableness (I KEA, Astrid Lindgren) or anguished moralism (Ingmar Bergman).

And so the question becomes: is it possible to discern a succession, a chronology, in the variety of Others in the European self-image? Which came earlier, which later? If we study, historically, the discourse and cultural production of non-European hetero-images, silhouetting successive European auto-images, which ones have left older, more deeply-rooted but more occluded traces, which one more recent, visible, superficial ones?

\section{3 \\ Moveable Placenames}

A final caveat. Over longer periods, the meanings of ethnic and geographical appellations shift. Although the Dutch ethnotype has remained fairly stable over the last centuries, the present-day country called The Netherlands is by no means co-extensive with its seventeenth-century or medieval forerunners. Belgium now has little in common with the part of Gaul described by Caesar as inhabited by the Belgae. And Europe has drastically shifted its (imagined) territory and centre of gravity over the millennia. And so the variable geometries that we need to apply involve a changing territory changing its character and self-image through juxtaposition with a changing succession of Others. All of which left echoes and traces in subsequent history.

The resulting complexities are daunting but not insurmountable or overwhelming: the self-profiling of something called 'Europe' is complex, but not chaotic or random. It is possible to discern successive paradigms. Naturally these are anything but homogenous in themselves and within them they carry both the residue of earlier discourse and the germinating anticipations of later developments; but that is almost a given for any historical period, and realisation of this fact cannot justify a defeatist 'non possumus', as if all of history were just a heap of messed-up glop. Continental drift is not measured in miles per hour, not does it proceed at an even rate in a unilinear direction; but directionality there is nonetheless.

The Continental drift in the documentary records of Europe's self-defining discourse, from Hesiod and Herodotus to the EU, can be mapped as a shrinking territory around a shifting centre of gravity. 


\section{Paradigms in Self-Perception}

The aim of this contribution is not to give a full account but rather to indicate some defining paradigmatic moments in order to see what, of all this, carried over into the current discourse of crisis.

\subsection{From Mediterranean Antiquity to Medieval Christendom}

Very broadly, then, ${ }^{4}$ we can see a stage zero when Europe is almost undefined as an area adjoining the Old World, largely maritime, mythically anchored between the Lebanon and Crete, Troy and Ithaca (marked as such by the journeys of Europa and Odysseus). The post-Herodotus Greeks invoke Persia as their contrast-frame, and face westward to a 'European' theatre of maritime communications between Gibraltar and the Black Sea. That Mediterranean footprint remains in force for the Roman Empire: Europe is bounded to the South by the Sahara, to the West by the Atlantic, to the East by the vast empires and deserts of Asia, to the North by the dank forests and chilly plains beyond the Alps. Alexander's sortie towards the Indus and the Nile, Caesar's to the Rhine and the Channel, extend but do not shift this concept of Europe, but Christianity will use the biblical, Sons-of-Noah-derived contrast frame of the Three Continents (Europe, Asia Africa). This post-Roman sense of a European identity will maintain its presence longest in the primacy of Rome and Constantinople (not, significantly, Jerusalem) as the religious capitals of Christendom.

The Others for this Europe are twofold: the nomadic barbarians (Scyths, Goths) roaming over the trackless plains, and the despots ruling their distant Oriental Empires. Both tropes will maintain a very stubborn persistence over the following millennia, albeit overlaid by later shifts and inflections. The role of 'nomadic hordes' is played by the barbarians bringing down the Roman Empire: Goths, Vandals, then also by Huns, Turkic Tatars and Mongols (Attila, Genghis Khan, Timur) from Asia, and Saracens and Arabs bringing Islam from the Middle East. The spread of Islam robs Europe of its southern anchorage: all of the southern coast of the Mediterranean now becomes alien territory, the opposite of Europe; the Mediterranean becomes a moat rather than a pond. Leo Africanus is the last intellectual for whom that sea is still a connecting rather than a dividing presence.

Post-classical Europe defines itself in religious terms as Christendom, and its defining Other for centuries is Islam. At Sankt Gallen, Notker the Stammerer

4 What follows in this section is a digest of Leerssen (2016b) and draws on the sources assembled there. 
notes Charles Martel's victory at Tours as one for the europenses - the first time that that word, 'Europeans', is used. ${ }^{5}$ Upon the completion of the reconquista, centuries later, the Spanish monarchy pursues its further expansion, significantly, not in the Maghreb beyond the Gibraltar straits - that is now firmly alien territory - but in the transatlantic world beyond the Pillars of Hercules. By that time Islam, having been pushed back in the west, is surging in the east: just before the conquest of Granada by the reyes católicos (1492), Mehmet II conquers Constantinople (1453); the Ottomans by then are already established in the Balkans and will expand towards Hungary and the gates of Vienna. That continues to be perceived as a European crisis, from which the continent derives a sense of identity: Enea Silvio Piccolomini (later Pope Pius II) and Charles V repeatedly plead the cause of 'Europe' in the face of Ottoman expansion. Piccolomini felt that the fall of Constantinople was qualitatively different from earlier confrontations with Islam, because it happened within the European ambit: "for in previous times we were wounded in Asia and Africa, that is: in alien lands; but now we have been shaken and stricken in Europe, that is to say in our fatherland, in our own home, in our residence". ${ }^{6}$

\subsection{Becoming Western}

By the time of Leo Africanus and Pius II, Europe as a religious post-Roman empire is fracturing. The Great Schism has turned Rome and Constantinople into opposing rather than complementary centres. And it occurred, fatally, a mere century before the rise of the universities (Bologna, Salamanca, Paris, Oxford). While in Western Christendom, abbey schools developed into universities and monastic learning developed into scholastic learning (Abelard, Aquinas, Roger Bacon), that process remained without parallel in the monastic world of Orthodoxy. As a result, Western Europe by the later Middle Ages had developed a self-image that drew heavily on Latin classics and opposed its pursuit of learning to the stagnant East. The Italian Renaissance and Humanism

5 Gesta Karoli Magni, I:17.

6 Enea Silvio Piccolomini, Constantinopolitana clades, speech held at the Frankfurt Diet, 1454. In the original: "[...] retroactis namque temporibus in Asia atque in Affrica, hoc est in alienis terris, vulnerati fuimus, nunc vero in Europa, id est in patria, in domo propria, in sede nostra percussi cesique sumus". Pius continues that this conquest is much more grievous than previous incursions of the Turks into Greece, or the Tatars into the Don basin, or the Saracens into Spain. ("et licet dicat aliquis ante plurimos annos ex Asia Turchos in Greciam transivisse, Tartaros citra Thanaim in Europa consedisse, Sarracenos Herculeo mari traiecto Hispanie portionem occupasse; numquam tamen aut urbem aut locum amisimus in Europa, qui Constantinopoli possit equari."). Pii II orationes (1755), vol. 1, p. 263f. Quoted in the source material for Helmrath (2007) and also Pius II (2006). 
became defining elements in a European self-image, priding itself on its intellectual curiosity. In the process, the Continent's Eastern half drops out of the European image as stagnant and dominated by uncouth despots. Only the Catholic chivalries of Central Europe (the Teutonic Order, Poles, Hungarians, Croats) maintained a tenuous connection as the self-styled 'bulwarks of Chris-

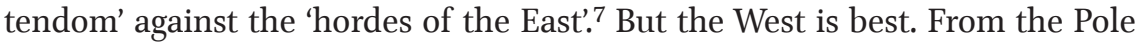
Copernicus to the Italian Galilei to the Englishman Newton, the scientific revolution is a Western affair, and ever more so; so is the growth of global colonialism, which - move over, Marco Polo - uses the Atlantic as Europe's sole path of access to the rest of the globe.

\subsection{Becoming Northern}

A further tectonic shift is introduced by the Reformation, which splits Western Christendom along a polarity soon construed as North vs. South - notwithstanding the fact that Geneva lies well south of Lisieux and Cracow. Crucially, the spread of Lutheranism coincides with the rediscovery of Tacitus's longlost tract Germania, and Luther is immediately framed as a latter-day Arminius-the-Cheruscan, thwarting Roman hegemony North of the Danube and East of the Rhine. ${ }^{8}$ In addition, a classicist temperamental frame comes into universal use opposing the cool temperaments of the cold north (phlegmatic Dutch, melancholic Germans) against the sensuous temperaments of the hot south (sanguine Italians, choleric Spaniards). This overdetermination of temperament, religion and geography becomes a lasting, ingrained stereotype, even influencing Max Weber's notions of a 'Protestant work ethic' motivating the rise of mercantilism and capitalism in North-Western Europe. The Enlightenment will intensify a European notion of a 'Republic of Learning' which is, de facto, anchored in Northern Europe; even its French intellectual denizens (Montesquieu, Voltaire, Diderot) advocate the virtues of moderation and a critical spirit in opposition to Southern Others like absolutist Spain or the Papacy. Actual latitude and longitude have little to do with this: Geneva as Protestant bulwark is a metaphorically Northern city; an eastern despot like Catherine the Great is, by virtue of her intellectualism, her German birth and the cold climate of her realm, metaphorically classified as 'northern'. And to the extent that scientific inquiry is also a eurocentric, ethnographic study of the 'primitive' races of the rest of the world, the encounter with them runs through

7 See Zrinka Blažević's contribution to this book.

8 See Borchardt (1971); Krebs (2011); Leerssen (2016c). On the discourse of climate and temperament underpinning North-South oppositions, the classical work is still Zacharasiewicz (1977). 
the colonial ports and the stock exchanges of the area Paris-London-Copenhagen-Frankfurt, now the centre of a core-Europe shrunk to the continent's North-by-North West.

This core-Europe can identify itself against any number of Others: the ancient empires of Asia; Islam; the nomadic tribes of (sub-)Saharan Africa and central Asia, or the equally nomadic savages of the New World, encountered during the colonial expansion post-1492. In addition, it can also silhouette itself against the tyrannical Romance-language monarchies of Catholic Southern Europe ${ }^{9}$ and the backward, Islam-threatened, feudal polities of Orthodox Eastern Europe. Core-Europe is the final resting place of a semantic-geographical slippage that saw the continent's imagined footprint shift and shrink from the Levantine Mediterranean to the West and then to the North; its centre of gravity moving from the Aegean by way of Rome across the Alps and towards the shores of the North Sea.

All the phases in that slippage process left a discursive repertoire of Othering in their wake with accumulating variants, one layer being superimposed on other, older ones. In the nineteenth century, that entire repertoire received the final overlay of an anxiety about the further possible 'westward course of Empire' towards the US or across the oceans; a Spenglerian Untergang des Abendlandes. The concomitant self-image sees Europe as old, decadent, experienced but feeble, when facing the rise of younger, brasher societies elsewhere. America is ambivalently either Europe's Western extension, further developing its self-attributions of free enterprise, individualism, and a inquisitive spirit, or else Europe's Other, uncivilised, simplistic, reckless, more brawn than brain. ${ }^{10}$

\subsection{Becoming Complex}

After an anguished need to confront the guilt of colonial misrule, world wars and genocide, Eurocentrism has dwindled to a mere vestige of what it used to be. The EU defines itself as post-totalitarian and dedicated to avoiding the reckless mistakes of the past. Europe's contemporary self-image is nothing if not a constant source of self-contradiction and anxiety. Other societies in the world are perceived as simple, one-dimensional, easily characterised; Europe, by contrast is felt to be complex, unintelligible, a maze lost in a labyrinth. Europe is also its own Other, with inner divisions, and the guilt of many bloodstained centuries of world hegemony, culminating in the twentieth-century

$9 \quad$ See Leerssen (2018), pp. 73-89.

10 I note only in passing the projection of this European anxiety on Asia, where 'the awakening of China' has been a constant fear factor since Napoleon, feeding into a 'Yellow Peril' discourse mixed with the old rejection of 'Oriential despotism'. 
dictatorships. Paradoxically, Europe can draw on its guilty conscience to claim a moral superiority vis-à-vis nations like the US or Turkey whose chauvinistic self-celebration - and their lack of guilt vis-à-vis their own genocidal past - is criticised as a symptom of political immaturity. ${ }^{11}$ It is in this aporia that the EU was confronted with the double crisis of an influx of refugees and the rise of xenophobic, populist neo-nationalism. (See below, section 6)

What are the constants and the variables in this succession of self-contrasts against ever shifting Others? The most recent strata, self-doubt, a sense of historical guilt and a sense of being post-totalitarian (culturally expressed in cinematic productions such as Das Leben der Anderen, Il Meglio Gioventù) are to be found largely on the political left where they bolster a sense of cosmopolitanism and anti-xenophobia. The older strata in the self-image are lastingly powerful for the discourse of the European right and centre-right. The image of 'Oriental despotism' - applied as it may be to ancient Persia, the Ottoman Empire and its Turkish successor state, and Russia (Tsarist, Communist or Putinist) - has continued to allow for a European self-identification with the values of liberal democracy, and with the values of the Enlightenment. In spite of ongoing secularisation, Islam is still Europe's most potent Other, particularly so in those Central-European countries still invoking a bulwark function vis-à-vis the Middle East.

The combination of these two auto-images allows for a discourse that despite is self-contradictory nature continues to make for efficient rhetoric: the fact that the European moral heritage consists of a combination of 'JudaeoChristian'12 and 'Enlightenment' values. Strictly speaking, that is as problematic as saying that Europe is characterised by its Socialist and its Free-Enterprise traditions, yet so ingrained is the formula that the public's habituation allows it to persist unchallenged. The two registers share, of course, the negative quality

\footnotetext{
11 See Leerssen (2017).

12 On the antecedents see Sebban (2012). On the contemporary political slogan see Molle (2019). The use of the term reached embarrassing depths when the German antiimmigration politician Horst Seehofer in March 2018 denounced Islam as being fundamentally alien to Germany with its 'christlich-jüdisch' historical imprint. Seehofer's anti-Islamism (and the public's preoccupation with that anti-Islamism) tended to draw attention away from the statement's jaw-dropping tastelessness: historically characterising what is, after all, the Third Reich's successor state by vaunting a claim to Jewish heritage for xenophobic purposes. See Bau (2018) and Vollmer (2018).
} 
that both implicitly contrast Europe as a Western sphere to a despotic, Islamic Orient. Islam can be used as Europe's contrast-frame both by those who reject it as un-Christian and by those who reject it as being illiberal. ${ }^{13}$

The north-south opposition feeds into contemporary austerity debates, particularly during the European debt crisis of 2009-12 where Mediterranean countries are opposed to a mistrustful northern Euro-zone dedicated to austerity measures and suspecting the Southern partners of profligacy and lack of proper financial accountability. ${ }^{14}$

The current political debates in Europe align various opposing policies with conflicting visions of what Europe is; and as a result, any conflict in Europe takes on the intensity of a conflict of identity, an existential crisis, something 'the European project' may not be able to survive.

Recent Others: A Swarm

Meanwhile Europe, post-1945, is being confronted by a new set of others: immigrants. These are an extremely diverse presence in the continent. They range from ex-colonial citizens (Algerian-born in France, West-Indies-, South-Asiaand Africa-born in the UK, Indonesia- and Surinam-born in The Netherlands) to immigrant labour (Italians, Greeks, Turks, Moroccans) attracted for mining or industrial employment in 1950s-7os Belgium, The Netherlands and Germany. Since 1989, refugees have sought sanctuary in Europe from war zones, tyrannical regimes and calamitous hardship in the Middle East and Africa.

The people habitually grouped together as 'immigrants' have very few common denominators either as to their geographical origin, the historical forces that impelled their migration into Europe, or even the period of their arrival. Accordingly, they are framed in their non-territoriality as a roaming 'swarm' or a 'horde', without specific link to a home country (as was the case in traditional ethnotypes). Their very heterogeneity marks them solely in the negative aspect of their not being native-rooted Europeans, and as such they are framed very differently from other transients in the European landmass such as post1945 Displaced Persons (liberated from the dictatorships' camps or driven from their homes by war or mass expulsions) or the modern-day tourists who are

13 An added irony is that it is often illiberal populists who denounce Islam for falling short of liberal values such as women's emancipation or acceptance of homosexuality. See Uitermark, Mepschen, Duyvendak (2014). 
now causing increasing friction in over-popular cities like Venice, Rome, Barcelona and Amsterdam. ${ }^{15}$

The generic non-characteristic as 'non-European' is remarkable because it overrides the usual contrast-frame as non-English, non-French etc. and thus, ironically, manifests an implicit European, rather than national, auto-image at work. It provokes unspecific and unfocused xenophobia, not linked to any specific character attributes or ethnotypes other than a perceived diminution of European authenticity and a tendency towards lawlessness and a disruptive effect on the fabric of society and the stability of the economy. This xenophobia recalls that aimed at earlier non-territorial alterities, Jews and Roma ('Gypsies'): Others within, rather than outside, the territorial boundaries of Europe. Tourists, a more transient 'swarm', do not present a transgenerational presence or a burden on economic resources (except in driving up real estate prices), and they are driven by a desire for entertainment rather than by dire necessity; but even so, they too are increasingly resented for their alienating impact and disruptive behaviour.

That contrast-frame, shared, in what must be the bitterest of irony, by hedonistic tourists and traumatised refugees alike, alerts us to what is perhaps the oldest and most persistent contrast-frame of all in the European self-image: that of roaming nomads vs. a local, orderly and sedentary society.

\section{7}

\section{Domesticity}

Among the core pantheon of the Roman Dii consentes, the ruling city deities, was Vesta. No shape-shifting, philandering or foe-slaying myths are associated with her as they are with the other gods. Instead she is best known for being worshipped in the eternal household fire tended by the Vestal Virgins, one of the most enduring city cults of ancient Rome. ${ }^{16}$ Like her Greek analogue Hestia, Vesta symbolizes both the domestication of fire as a tool of civilisation, and the principle of living in fire-centered houses, with a roof over one's head,

15 The pied noirs who moved to France after Algerian independence can be ambivalently categorised either as 'intra-European Displaced Persons' or as 'extra-European foreigners from overseas'. Tourists are on the whole non-sedentary and (as individuals) a short-term presence; even where they acquire real estate as 'expats' (e. g. Britons in Spain) this is usually at an age when they do not start families in the country of arrival. They are also a mixed group consisting of Europeans and non-Europeans alike. Rich expats in places like London or Monte Carlo (Russian 'oligarchs' and Middle-Eastern 'oil sheikhs') are an ambivalently framed group.

16 See Goux (1983). 
a fireplace in the middle, and a threshold separating the inner sphere of cleanliness from the mundanity of the world outside. ${ }^{17}$ Like Janus, the threshold deity (cf. Latin ianua, 'doorway'), and the Lares and Penates, she was a goddess of domesticity and ordered stability, requiring only the dutiful observance of maintaining the hearth-fire in the house; as such her worship was private as much as public. Indeed the temple of Vesta, constructed on the plan of a traditional Roman domus, can be seen as the city's very fireplace, turning the entire city metaphorically into a meta-house.

The domestic centrality of the fireplace, and its architectural location at the inner core of the house-dwelling (as its Latin name, focus, suggests) provide a potent auto-image against which all societies stood out as barbarians who cooked their food out of doors, under the open sky. Very deeply embedded in the European self-image lies its opposition to nomadism and camp-fires, its reliance on ordered stable domiciles with a tended fire at their centre and a roof over their head. Against this auto-image, anyone living in encampments with campfires stands out as an alien - be he a Bedouin, a Gypsy, a nomad or a refugee.

The notion of domesticity may amount to an 'absolute metaphor' in Hans Blumenberg's sense of the word. In Blumenberg's view, certain metaphors are so ingrained and fundamental to our conceptualisation of the world that they are not just associative similes tagged on to our primary concepts, but rather intrinsic elements of our understanding. ${ }^{18}$ Seeing society as an extension of one's household is such an absolute metaphor; the use of oikos (the Greek word for household) in terms like 'ecology' or 'economy' indicates this. ${ }^{19}$ Likewise the word 'domestic', derived from domus, 'house, home' is non-metaphorically, immediately, applied to whatever occurs within our own society as opposed to the world outside it. ${ }^{20}$

The conceptual opposition between an ordered world inside the walls and a violent, unruly wilderness outside, can be traced back as far as Heraclitus's dictum that "We should protect the laws as if they were our city walls". 21

17 The classic theory on the demarcation clean-unclean remains Douglas (1966).

18 The idea of an 'absolute metaphor' was outlined in Blumenberg (1960) and further elaborated in Blumenberg (1979a) and Blumenberg (1979b).

19 See Nagle (2006). On the oikos in economic thought from Aristotle to Marx see Booth (1993).

20 There is a considerable body of reflection on 'making oneself at home in the world', e. g. Bollnow (1963). A recent, keen analysis of the home-affect is Duyvendak (2017).

$21 \quad K a h n$ (1979), p. 59 (nr. LXV). Kahn comments p. 179 that Heraclitus elsewhere compares violence and lawlessness (hybris) to a house on fire. This underscores the parallel between two oppositions: on the one hand between order and chaos, and on the other hand between inner sphere and outside. For a political elaboration of this idea, see Eijsbouts (1993) and Leerssen (1999). 
Europe as domesticity: on closer scrutiny, examples turn out to suffuse the European discourse of self-identification and othering over long periods. Prior to the crisis of $145^{2}$ (to recall Pius II's qualification of Europe as 'our own home, our residence'), Giraldus Cambrensis, writing in 1188 in his Topographia Hibernica, had already activated the contrast-frame when evoking the savage lack of civility of the native Irish as being, almost literally, 'beyond the pale'. The Irish are, as he puts it,

forest-dwellers, and inhospitable; a people living off beasts and like beasts; a people that still adheres to the most primitive way of pastoral living. For as humanity progresses from the forests to the arable fields, and towards village life and civil society, this people is too lazy for agriculture and is heedless of material comfort; and they positively dislike the rules and legalities of civil intercourse; thus they have been unable and unwilling to abandon their traditional life of forests and pasture. ${ }^{22}$

The stadialism is unmistakable: proper, regulated society is organised in cities and villages, subject to the rule of law, and with a reliable, industrious subsistence in the form of agriculture and trade. The hand-to-mouth life of nomads falls below this standard, roams around in territorially unmarked forests, and is closer to the life of animals than to that of proper humans. Concomitantly, the Irish have no regulated family life: "They pay no tithes or harvest sacrifices, they do not celebrate marriage, they shun no unchastity and neglect to visit God's church with the necessary respect."23

\section{$8 \quad$ Family Values}

Any reader will, upon reflection, realize that the xenophobic Othering of migrants will invariably frame them as unattached single males. The notorious 'Breaking Point' poster that fed the British Brexit campaigns showed long waiting crowds of migrants at a border crossing point in Slovenia, glaring ominously at the British electorate in their intent to approach Britain by way of Europe; ${ }^{24}$ and the salient characteristic that they had in common was that they were an aggregate of single, male individuals. This, of course, is a characteristic also of any invading army: women and children rarely form the frontline of attacking storm troopers. A very deep-seated schematisation in such

\footnotetext{
22 Giraldus Cambrensis (1982), p. 162 f.

23 Giraldus Cambrensis (1982), p. 166.

24 See Morrison (2016).
} 
representation is that the threatened domestic space is familial, inhabited by wives and children, and the invaders are violent hordes of males. As the Marseillaise has it: "Entendez-vous, dans les campagnes, / mugir ces féroces soldats? / Ils viennent jusque dans nos bras égorger nos fils, nos compagnes." 25

Thus, the hordes of untrustworthy single males were implicitly aligned with an invading army and implicitly opposed to an English domesticity exemplified, in that precise period, by the familial and social harmony of that decade's exemplification of domestic Englishness, Downton Abbey - an Englishman's home which is, quite literally, a castle, as well as a feel-good comfort zone for the viewers.

Conversely, any representation that evinced sympathy for the plight-driven migrant would evoke them as being, indeed, familial: couples with children, driven from their home by féroces soldats and as such deserving shelter and sympathy. As evocative as the picture of the waiting male crowds was that of the drowned toddler washed up on a Greek beach. A counter example of a policy of welcoming and sheltering refugees was the Canadian one, which was invariably framed, also in the accompanying press coverage, as welcoming refugee families. ${ }^{26}$

\section{9}

\section{Securing the Perimeter}

How do we frame Europe? The contemporary crisis discourse draws on a very long-standing image of Europe's Others as nomads, be they Wild Irish, Mongols or Tatars, Saracens, Bedouins or Arabs (or native Americans and Australians, later on). Their telling characteristic is, almost tautologically, that they have no houses. Without fixed indoor fireplace at the inner core of their dwelling, they live in moveable tents or conveyances and their fireplaces are typically outside, under the open sky. Camp fires as opposed to hearths. Aimless, plundering mobility rather than ordered, sedentary existence within domestic or city walls. The implied European self-image draws on the notion of an ordered household, whose thresholds must keep the polluting dangers from the outside world at bay and maintain the inner order, which is domestic both in the

25 "In our lands can you hear those fell soldiers howl? / They come to cut the throats, even in our embrace, of our children and our women." [Transl. J. L.].

26 Compare the website of the Canadian Council for Refugees, ccrweb.ca/en/psr-toolkit/ other-useful-info-family-reunification; any google search for 'Canada refugee family' will bear out the point. 
sense that it draws on the house-metaphor and on the notion of the family as its rightful occupant.

Europe in its early-twentyfirst-century crisis has two borders with its newly emerging Other. One is physical: it consists of non-domestic spaces of transient occupancy: 'supermodern' non-lieux (in Augé's sense) ${ }^{27}$ such as airports, motorway rest areas, tourist campsites; and - most disturbing of all - refugee and immigration detention camps, those spaces identified by Giorgio Agamben as being outside the state's proper governance and in a "State of Exception". 28

Europe's other border with the outside world is mental, and now dominated by a manipulative discourse weaponising deeply-ingrained 'absolute metaphors' like home and family for the purpose of xenophobic rhetoric. To understand that rhetoric properly, the mere analysis of ethnotypes proves to be insufficient, and may almost collapse into the demonstration that the discourse of Othering Others is ethnocentric - a vapid pleonasm if there ever was one. How that discourse functions involves the instrumentalisation and skewed distribution of absolute metaphors of a moral nature - where 'moral', in the root sense (as derived from the Latin mores), refers both to a set of accustomed, ingrained behavioural patterns and to a value-system rationalising those patterns by means of value judgements. Nationalism post-1989 may well take the form of the nation's moral monopolisation of something as cute and uncontentious as 'family values' - trivial, banal entertainments like Downton Abbey and The Great British Bake-Off accompanying, and covertly justifying, the logic of Brexit.

\section{Bibliography}

Agamben, Giorgio (2004). State of Exception (Chicago: University of Chicago Press).

Augé, Marc (1992). Non-Lieux. Introduction à une anthropologie de la surmodernité (Paris: Seuil).

Bau, Walter (2018). 'Von Wulff bis Seehofer. Gehört der Islam zu Deutschland?, Berliner Morgenpost, 16 February. www.morgenpost.de/politik/article213737863/Von-Wulffbis-Seehofer-Gehoert-der-Islam-zu-Deutschland.html [accessed 24.06.2019].

Beller, Manfred, Joep Leerssen (eds) (2007). Imagology. The cultural construction and literary representation of national characters. A critical survey (Amsterdam, New York: Rodopi).

27 See Augé (1992).

28 See Agamben (2004). 
Blumenberg, Hans (1960). 'Paradigmen zu einer Metaphorologie', Archiv für Begriffsgeschichte, 6, pp. 5-142. Book reprint (1997).

Blumenberg, Hans (1979a). Arbeit am Mythos (Frankfurt a.M.: Suhrkamp).

Blumenberg, Hans (1979b): Die Lesbarkeit der Welt (Frankfurt a.M.: Suhrkamp).

Bollnow, Otto Friedrich (1963). Mensch und Raum (Stuttgart: Kohlhammer).

Booth, William James (1993). Households. The Moral Architecture of the Economy (Ithaca: Cornell University Press).

Borchardt, Frank L. (1971). German Antiquity in Renaissance Myth (Baltimore: Johns Hopkins University Press).

Douglas, Mary (1966). Purity and Danger. An Analysis of the Concepts of Pollution and Taboo (London: Routledge \& Kegan Paul).

Duyvendak, Jan Willlem (2017). Thuis. Het drama van een sentimentele samenleving (Amsterdam: Amsterdam University Press).

Dyserinck, Hugo (2015). Ausgewählte Schriften zur Vergleichenden Literaturwissenschaft (Berlin: Frank \& Timme).

Eijsbouts, Willem Thomas (1993). 'Borders and Democracy. The Schengen Treaties', Yearbook of European Studies, 6, pp. 57-70.

Giraldus Cambrensis (1982). The History and Topography of Ireland (Harmondsworth: Penguin).

Goux, Jean-Joseph (1983). 'Vesta, or the place of being', Representations, 1, pp. 91-107.

Helmrath, Johannes (2007). 'Enea Silvio Piccolomini (Pius II.). Ein Humanist als Vater des Europagedankens?', Themenportal Europäische Geschichte. www.europa. clio-online.de/essay/id/fdae-1327 [accessed 24.06.2019].

Kahn, Charles H. (1979). The Art and Thought of Heraclitus. An Edition of the Fragments with Translation and Commentary (Cambridge: Cambridge University Press).

Krebs, Christopher B. (2011). A Most Dangerous Book. Tacitus's "Germania" from the Roman Empire to the Third Reich (Cambridge, Mass.: Harvard University Press).

Leerssen, Joep (1999). 'Law and Border. Were and How we Draw the Line', Irish Review, 24, pp. 1-8.

Leerssen, Joep (2016a). 'Imagology. On invoking ethnicity to make sense of the world', Iberic@l, Revue d'études ibériques et ibéro-américaines, 10, pp.16-31.

Leerssen, Joep (2016b). Spiegelpaleis Europa. Europese identiteit als mythe en beeldvorming (3rd edn Nijmegen: Vantilt).

Leerssen, Joep (2016c). 'Tribal Ancestors and Moral Role Patterns', in Joanne Parker (ed.), The Harp and the Constitution. Myths of Celtic and Gothic Origin (Leiden: Brill), pp. $13^{-25}$.

Leerssen, Joep (2017). 'Stranger/Europe', in Acta Universitatis Sapientiae (Philologica), 9.2, pp. $7-25$.

Leerssen, Joep (2018). National Thought in Europe (3rd edn Amsterdam: Amsterdam University Press). 
Molle, Andrea (2019). 'Religion and Right-wing Populism in Italy. Using "Judeo-Christian roots" to Kill the European Union', Religion, State and Society, 47.1, pp. 151-168.

Morrison, James (2016). 'Break-Point for Brexit? How UKIP's Image of "Hate” Set Race Discourse Reeling back Decades', EU Referendum Analysis 2016. www.referendumanalysis. eu/eu-referendum-analysis-2016/section-5-campaign-and-political-communication/ break-point-for-brexit-how-ukips-image-of-hate-set-race-discourse-reeling-back-decades/ [accessed 24.06.2019].

Pii II orationes politicae et ecclesiasticae (1755-1759), ed. by Johannes Dominicus Mansi. 3 vols (Lucca: Benedinus).

Pius II (2006). 'Enea Silvio Piccolomini über Europa und die Türken. Auszüge aus "Asia”, “De Europa”, “Constantinopolitana clades", "Epistula ad Mahometem”, 14541461', Themenportal Europäische Geschichte. www.europa.clio-online.de/quelle/id/ q63-28286 [accessed 24.06.2019].

Sebban, Joël (2012). 'La genèse de la "morale judéo-chrétienne". Étude sur l'origine d'une expression dans le monde intellectuel français', Revue de l'histoire des religions, 1, pp. 85-118.

Sierp, Aline (2017). 'Dividing United Europe. Stereotypes, Prejudices and the European (Economic) Crisis', National Identities, 19.1, pp.1-9.

Uitermark, Justus, Paul Mepschen, Jan Willem Duyvendak (2014). 'Populism, Sexual Politics, and the Exclusion of Muslims in the Netherlands', in John R. Bowen et al. (eds). European States and their Muslim Citizens. The Impact of Institutions on Perceptions and Boundaries (Cambridge: Cambridge University Press), pp. 235-255.

Vollmer, Frank (2018). 'Christlich-jüdisch? Anmaßung!', RP Online, 30 April. https://rponline.de/politik/christlich-juedisch-anmassung_aid-22209073 [accessed 24.06.2019].

Zacharasiewicz, Waldemar (1977). Die Klimatheorie in der englischen Literatur und Literaturkritik von der Mitte des 16. bis zum Ende des 18. Jahrhunderts (Vienna: Braumüller). 


\title{
The EU and the East-West Paradox
}

\author{
The Case of Greece and Turkey
}

Hercules Millas

\begin{abstract}
In both Greece and Turkey anti-western discourse is widespread. On the one hand both societies perceive themselves as European, but at the same time they criticize the 'West' as religiously or culturally different from 'us', being prejudiced against 'us', siding with our rivals, as hypocritical, cruel or imperialist. These stereotypes have real or imaginary historical dimensions, but they also relate to recent political controversies. While the rationalisations of these images are not identical in the two countries, the contradictory end results are quite similar. While they criticize the West, neither the Greeks nor the Turks associate themselves with the 'East' or any 'eastern' country. When all these ambiguities are taken into consideration one may conclude that the anti-West/Europe discourse is used as a political means to voice complaints and demands: 'You do not accept a cut on our debt', or 'You do not accept us in the EU'. These are accusations that show the 'self' as a victim. They also show a national identity in anguish: 'We are being treated unjustly, humiliated, etc'. This discourse also operates indirectly as a means of comparison with the 'developed Western' countries, stating ones own moral and cultural superiority.
\end{abstract}

On January 9, 2017 the president of Turkey R. T. Erdoğan accused the 'West' of being hypocritical. In his speech to a group of Turkish governors in Ankara he said that even if one leaves aside some negative practices of the West such as "their inhuman treatment towards the refugees and their lack of sensitivity when children, women and old people were killed", ${ }^{1}$ still the hypocrisy is seen when one considers how the West reacts when a terrorist action takes place in the West and how it remains indifferent when a similar action takes place in Turkey. He also inferred that the 'West' is against Turkey.

Accusations against the 'West' are common in Greece, too, especially after the economic crisis of 2010. The president of Greece Prokopis Pavlopoulos,

1 Erdogan (2017). All translations from Turkish and Greek sources are by the author.

(C) HERCUlES Millas, 2021 | DOI:10.1163/9789004436107_009

This is an open access chapter distributed under the terms of the CC BY-NC-ND 4.0 license. 
for example, in 2013 called the agreement with the EU and IMF which aimed at coping with the economic crisis in Greece "a dishonourable pitchfork to which the government gave in". ${ }^{2}$ The Union of Judges and Public Prosecutors in February 2016 unanimously declared that "the Greeks should stop being the economic guinea pigs of Europe". ${ }^{3}$ Vassiliki Thanou, the head of the Supreme Court sent a letter to her counterparts in the European Union in July 2015 stating that the Greek people are not responsible for the state debt, but rather the EU governments and the IMF, and that the creditors "should not seek the extermination of the debtor." 4

However, when such Turkish and Greek accusations are put side by side a paradox comes into view. In an article in a Greek blog titled The hypocrisy of the West should end the EU and the USA are criticised for not taking a clear stand against R.T. Erdoğan's authoritarian policies of the last few years. So the 'West' is seen as hypocritical for not being pro-Turkey in Turkey; but it is seen as hypocritical for being pro-Turkey in Greece. ${ }^{5}$ That Greece is 'the spoiled child of the West' because they are seen as the heirs of Ancient Greece is an old and established term in Turkey; in stark contrast to Greek perceptions of anti-Greek bias in the 'West'. In other words, both sides perceive the 'West' as unjustly siding with 'our opponent' - but for different and contradictory reasons.

When national discourses and ethnotypes are studied comparatively they may prove to exhibit remarkable similarities between sharply distinguished groups. Conversely, 'universal' traits turn out to be asymmetrically ascribed across borders or between groups. In what follows, I will try to present some peculiarities of Greek and Turkish 'Occidentalism', i.e., the way the so-called 'West' is understood in both countries' use of images, stereotypes and contradictions.

\section{Anti-Westernism in Numbers and in Meaning}

Opinion polls show that in both Greece and Turkey anti-western feelings run high. According to the Pew Research Center findings, in 2014 the top six countries that are critical of the US are Egypt (85\%), Jordan (85\%), Turkey $(73 \%)$, Russia (\%71), Palestine (66\%) and Greece (63\%). Pakistan and Lebanon

2 See Kroustalli (2017). The declaration was made in September 2013, before Pavlopoulos was elected president.

3 ToVima (2016).

4 Iefimerida (2015).

5 See Voria.gr (2016). 
follow. ${ }^{6}$ Two aspects are of interest: a) Turkey and Greece are allies of the US in NATO, but still they emerge as top opponents; b) Among the top eight 'critics' are only Muslim and Orthodox Christian countries or populations. Conversely, among the top eight 'US fans' - the Philippines, Israel, South Korea, Kenya, El Salvador, Italy, Ghana and Vietnam - there are no Muslim or Orthodox Christian countries.

According to the Greek Palmos Analysis' opinion poll, at the end of 2016 $84 \%$ of Greeks believe that the EU is moving in the wrong direction and only half of the participants of this survey are in favour of staying within the EU.7 An opinion poll in Turkey 2015 showed that the wish to join the EU among the Turks - which in 2005 was of the order of $70 \%$ - during the last four years decreased to a low of $20-35 \% .^{8}$ According to a more recent opinion survey in Turkey $68 \%$ of Turks want to terminate the negotiations for the country's entrance to the EU, believing that the westerners are not "sincere" $(82 \%)$ and do not want Turkey entering the EU because "the Turks are Muslims" (6o\%). They also believe that western discourse related to Turkey is "humiliating". ${ }^{9}$

These complaints go beyond criticising the doings of the 'West' and of the 'westerners'; their actions are presented as being motivated by ill intentions and/or the problematic 'character' of the 'West'. Disagreement thus moves into the emotional, even phobic register of temperamental ill-will imputed to a 'West' perceived as unjustly biased 'against us.'10

In the few examples referred to above, for example, the anti-west utterances impute the West to be inhuman and insensitive when facing the unhappiness of the world; the West is hypocritical, has a wicked 'character', imposes dishonourable sanctions on 'us', has turned 'us' to guinea pigs, the policy of the West signals our 'extermination'. These allegations and the words in which they are couched show that the grievances are part of a group opposition rather than a policy disagreement. The conflict is sparked by the incompatibility between these groups' different ethical values, perceptions of justice, opposing worldviews and dissimilar cultures.

In Greece and in Turkey the 'West' features in many historical narratives, in politics, in textbooks, the media, literary texts, the arts and even in books for children. There is a substantial bibliography related to negative Western

6 See Question 15a of the Pew Global Studies survey 2014 (2014). This favourability distribution shifted slightly following the election of Donald Trump as US-President.

$7 \quad$ Palmos Analysis (2016).

8 See Haber 3 (2015).

9 Internet Haber (2016).

10 For 'our image' vis-à-vis of 'how the Other sees Us' (i. e., meta-image) see Leerssen (2016). 
images of the East; ${ }^{11}$ such orientalism is encountered both in Greece and in Turkey. But the image of the West in these countries - Levantine Occidentalism - deserves closer study. ${ }^{12}$ I will give some limited samples to show the range of this anti-western discourse. The discourse itself involves the following imputations and characterisations, digested here from the various sources listed in the bibliography:

- The West is a monolithic, uniform, homogeneous entity which can be subsumed under this singular appellation;

- The West has no specific geographic boundary; it may be the EU, the USA, Europe in general, the western Europe of the Renaissance and the Industrial Revolution, and may or may not include the Balkans;

- It is religiously different. Among Greek orthodox spectants it is seen as Catholic and Protestant, among Turkish Muslims as Christian. These religious differences are imagined in a historical context, too. Greeks recall the Great Schism of 1054, Turks the wars between the Ottomans and the Europeans. Both 'remember' the crusades.

- Besides the religious difference, there is an adversarial perception of the West as pursuing either its national interests as great powers, or economic exploitation as colonial hegemons.

- As such, the West may be suspected of being in league with other, unspecified enemies.

- The West is prejudiced against 'us' and harbouring negative stereotypes of 'us': Turks feel they are perceived as uncivilised, Greeks feel they are perceived as lazy and as unworthy descendants of a glorious ancestry. ${ }^{13}$

- Temperamentally, the self-interest of the ruthless and cynical West is opposed to the positive characterisation reserved for the 'We'-group: humane, hospitable, righteous, sensible, honest, honourable.

The East-West issue plays an important part in both Greek and Turkish historiography. In the Greek's case the East-West controversy became a major issue

11 See Said (1994), which is well known, especially in Turkey. Also see Todorova (2009) where the perception in the Balkans is discussed.

12 See, for example Carrier (1995) and Buruma, Margalit (2005).

13 On these meta-images - how the Other sees us -, see Millas (2001); Millas (2005a); Millas (2005b). 
during the years of the Greek War of Independence of 1821-29. ${ }^{14}$ The revolutionaries, mostly diaspora intellectuals based in various cities of Western Europe and influenced by the ideals of the French Revolution, promoted the 'western' ideas. Conservative Greeks, mostly close to the patriarchate of Constantinople and living within the Ottoman state, anathematised these Enlightenment modernizers, such as Paris-based Adamantios Korais (1748-1833), and advised prudent adherence to 'paternal ideals' as opposed to Western innovation. ${ }^{15}$

With the establishment of the modern Greek nation-state (1830) a modus vivendi was accomplished between the two sides of this controversy. ${ }^{16}$ The republican discourse was silenced and a Holy Alliance (between the throne and the altar) was secured. A straightforward national myth dominated nineteenth-century historiography: The Greeks, descendants of the glorious ancient Hellenes, had after many centuries under Ottoman rule thrown of the tyrannical 'Turkish yoke' and regained their independence. Greek-Orthodox Christianity, the basic belief of most of the Greek cultural community, was dexterously integrated into the ancient heritage. Spiridon Zambelios coined the concept of 'Helleno-Christianity' in the mid-nineteenth century to express this national harmony, and religion was thus 'ethnicised' during this nation-building phase. Greekness was closely associated with religion, and in particular with the Greek Orthodox Church and its legacy. Thus the two historicist repertoires, secular Antiquity and the Orthodox Christian heritage, have coexisted in an oblique West-East polarity until the present day.

In recent decades a number of researchers emphasising the contribution of the Greek Orthodox Church seem to have reproduced the old opposition between East and West and between believers and unbelievers. This religion-related movement in Greece is known as 'New Orthodoxy'. The following quotation from G. Metallinos, a well-educated historian and priest, can serve as an illustration. I have added some clarifying comments.

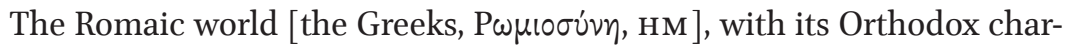
acter and as the heir of Hellenism, had always been irksome to Frankish Europe [...]. The West had a permanent aim: the destruction of the Romaic civilization. The Frankish attempt in 1204 [to capture Constantinople, $\mathrm{HM}$ ] failed, as it failed to Latinize the Orthodox East. The blow of 1453 [the capture of Constantinople by the Ottomans, HM] was not strong enough to kill the Romaic world either. During the years of slavery

\footnotetext{
14 See Millas (2008).

15 See Dimaras (1985).

16 For this and the following see Grigoriadis (2013).
} 
[Ottoman rule, $\mathrm{HM}$ ] all the westerners, i.e., those tied to the Pope and the Protestants, the missionaries and all the western political propaganda were defeated. So Romiosini could experience its resurrection again. [...] The political aim of Europe [i.e. non-Orthodox Europe, HM] was not only the partition of the Ottoman Empire but also to obstruct the expectation that it would give way to a renewed Greek and Orthodox empire. ${ }^{17}$

The same author represents Western Enlightenment and related ideas as foreign ideals that did not normally develop within Greek society and were contrary to the Greek tradition. He also asserts that the Western Powers (England, France, Holland etc.) eventually sided with the Turks, seeking their own self-interests and not helping Greece. ${ }^{18}$

Hristos Yiannaras is probably the most well-known representative of the New-Orthodoxy movement. According to him the East and the West have always been two different worlds. Unlike the East, the West is materialist and selfishly individualist and has strayed from true Christianity. "Actually, in the West we have anti-Christianity and hatred for the Greeks". ${ }^{19}$ The Western world is hedonistic, corrupt, guilty of barbarities like the Inquisition, Auschwitz, Hiroshima, and more recently the massacres of Serbs. The West is hypocritical and on the side of the enemy of Greece, namely Turkey; conversely, the Orthodox 'personality' of the Greeks is superior to the West. ${ }^{20}$

In Greece the political spectrum accommodates anti-western groups besides the New-Orthodoxy. The extreme right-wing Hrisi Avgi (Golden Dawn) which has eighteen deputies in parliament (out of a total of 300 members) is one of them. Their opposition to the 'West' is not based on religion but on political and racial considerations. Still, there is an indirect relation with the New-Orthodoxy as it is apparent from their references to its theoreticians such as Yiannaras and Metallinos. ${ }^{21}$ On the official website of Hrisi Avgi, for example, in an article related to the ideology of this movement, we read that the West always fought the Greeks by means of Jews:

As the professor of philosophy Hristos Yiannaras says [...] the Jews (like Marx, Freud, Einstein, Kafka, Steinberg, Woody Allen, Claude Lévi-

17 Metallinos (1988), p. 175. For the metaphorical 'resurrection' of the Greek nation-state, alluded to in this passage, see Millas (2006), pp. 47-6o.

18 See Metallinos (1988), pp. 151, 94.

19 Hristos Yiannaras as quoted by Heraclides (2001), p. 84.

20 See Heraclides (2001), p. $86 f$.

21 For a critical presentation of Yiannaras see Heraclides (2001). 
Strauss, etc.) were the spokesmen of the civilization of Western Europe but actually they did not create any original thinking. They only copied whatever the Greeks have accomplished and thus they promoted the Jews. Instead of Plato they created the Jewish philosopher Aristobulus of Alexandria who claimed that Plato had read the text of Moses; instead of Kant, the new-kantianist Hermann Cohen; instead of Epicurus, Marx; instead of Constantin Carathéodory, Einstein, etc. So Greece says that it belongs to the West, but the West plans its extinction. ${ }^{22}$

The communist and socialist Left often uses an anti-western discourse based on ideological principles couched in Marxist terminology. ${ }^{23}$ The 'West' (USA and EU) is generally perceived as a capitalist and imperialist block. Thus we find this statement on the official website of the Greek Communist Party KKE:

The jihadists are powers that were supported and armed by the USA, NATO and the EU in order to implement their plans in Iraq, Syria and Libya and today they are used as a pretext for new interventions and wars $[\ldots]$. The Greek people must fight so that Greece is not part of NATO and other similar organisations which cause the bloodshed of nations in the interest of capital. ${ }^{24}$

Syriza followers use a less strident wording but the attitude is not much different. On the website of Syriza in an article on the island of Zakinthos titled The heart-breaking nightfall of the West we read evaluations such as these in relation to the Arabic Spring and the refugee crisis:

From the beginning the West showed first its foolishness and then its cruelty. Naturally, this is not the first time that the West shows its cruelty. In 1939 when 937 Jew refugees ran away from Hitler and were going up and down in the Atlantic neither USA nor Canada accepted them. [...] And now the civilised EU which claims that it has abolished its borders,

\footnotetext{
22 Karaiskos (2016).

23 The left in Greece is presently composed of the Greek Communist Party (KKE) with 15 deputies in parliament, and Syriza (Radical Left Coalition) which is in power at present with 145 deputies. There are about ten small leftist groups, which participate in the general elections but are not represented in parliament. All together the left composes $41 \%$ of the parliament and about half of the electoral public.

24 Katsaros (2014). Official declaration of KKE on 25.9.2014, in connection with the declaration of the Greek Ministry Foreign Affairs on fighting the Islamic State.
} 
re-imposes them in the cruellest way. [...] The cynical arrangement between the EU and the regime of T. Erdoğan on the issue of the refugees is an example of the neo-colonialist policy of the EU. [...] Often the Western type of haughtiness haunts the so-called backward Arabs. ${ }^{25}$

Again, critiques of the 'West' go beyond the denunciation of actual or imagined misdeeds, but explain those with an intrinsic 'character', the unchanging essence of the 'West'. The West was in the past as it is now, and new misdeeds are reiterations of older ones. Accusations of this kind are commonplaces among many followers of the left ideology.

The 'East-West issue' - as the relations of Turkey and the Turks with the 'West' are called: Doğu-Batı sorunsalı - dominates all aspects (historical, social, cultural) of Turkish society over the last two hundred years. The 'East-West issue' crops up in any major social topic; largely because the most vital social changes were initiated, caused or influenced by the country's relations to the 'West'.

Starting from the time of Sultans Selim III (1761-1808) and especially Mahmut II (1785-1839) the Ottoman Empire initiated a series of reforms of 'Westernisation' (later known as Batılılaşma). ${ }^{26}$ The modernisation of the state in order to cope with the 'West' had appeared as a necessity after a series of military defeats against the European powers. The changes were many and covered various fields. ${ }^{27}$ Selim created a new treasury, opened a navigation school and attended to printing and to the circulation of Western translations. Mahmut was much more radical. He abolished the Janissary Corps in 1826, establishing a western type Ottoman Army. In 1831 he founded an official gazette, Takvim-i Vekayi (Calendar of Events), the first newspaper to be published in the Ottoman-Turkish language. Instead of a vizier, a prime-ministerial office was established, and a new bureaucracy appeared with western-type ministers. New schools, mostly military academies were established. Young Turks were sent to Europe for studies.

Those innovations, however, were limited. The state aimed at benefitting from Europe's scientific knowledge insofar as this could be done without transplanting European culture into the empire. In 1839 the Tanzimat era started

\footnotetext{
25 Karaiskos, Thanasis (2016).

26 See Zürcher (2004).

27 See Hanioğlu (2008), pp. 55-108.
} 
establishing equality between Muslims and non-Muslims. These reforms known as Hatt-1 Humayun were reaffirmed in 1856 and rendered necessary because of Muslim reluctance to grant equality to the non-Muslim millets, i.e. to the citizens of the Empire. At this point a class bifurcation became clear: The Westernisation process became a movement of the cities and of the elite of the Muslim population. From dresses to everyday life a western way started to be accepted in the Empire by the Muslim elite population. However, at the popular level, in the agrarian and mostly Anatolian section of society the reforms met with reservations.

The most important counter voice was that of the former bureaucrats labelled as the Young Ottomans. They criticised Tanzimat as 'capitulation to the European dictates.' Established as a secret society in 1865 by a group of intellectuals such as Şinasi, Namık Kemal, Ali Suavi and Ziya Pasha, the Young Ottomans agreed that a new constitutional government should continue to be somehow rooted in Islam, emphasising "the continuing and essential validity of Islam as the basis of the Ottoman political culture."28 The acceptance of Western laws instead of the Sharia was considered tyranny, and the example of Europe should be limited to scientific and industrial progress. ${ }^{29}$

This dualism of modernisation and westernisation versus local, national and Islamic tradition started a struggle that is still not resolved. About forty years after the Young Ottomans, another reformist group, the Young Turks, triggered a revolution in 1908, the beginning of a Constitutional Era. With the Young Turks, nationalism emerged among Turks and Ottoman Muslims. This nationalism was fanned by the Balkan Wars (1912-14), the First World War (which ended in defeat for the Ottoman State), a post-1919 invasion by Entente powers, and a War of Independence (1919-22). During these developments the negative image of the West evolved further.

On the surface, the ambiguity vis-à-vis the 'West' as what to take and what to refuse seemed to continue unabated. Ziya Gökalp, for example, the theoretician on ideological matters both of the Young-Turks and of the Kemalist new Turkish Republic, repeated the formula: the technology of the West should be adopted, while at the same time protecting and strengthening the nation's characteristics. ${ }^{30}$ In fact, Gökalp in 1918 made a clear distinction between culture and civilisation (hars and medeniyet). Civilisation is what the upper classes share worldwide; culture is what characterizes each group of people

\footnotetext{
$28 \quad$ Bora (2002), p. 253 .

29 The Westernisation debates were very complex and full of ideological nuances. See, for example, Bora (2002). Here I limit myself to a broad outline. 
separately, and what secures the existence of the nation. ${ }^{31}$ According to Gökalp the culture of a nation is of greater importance since it preserves its identity, its values and its character. He was very much in favour of the preservation of what he saw as genuine Turkish-Islamic culture. In essence this attitude, as articulated by the Young Turks and Gökalp, has remained in force until our days. The official Turkish position was and still is that Turkey is to be part of the West, but naturally preserving what it sees as its Turkish national identity.

However, an important ideological change vis-à-vis the 'West' occurred with the rise of Turkish nationalism starting in the year 1910. This change, which assigned new negative characteristics to the 'West', was not actually noticed and adequately understood because it was seen and internalised as a given reality rather than as an attitude or image. Apart from being advanced, rich, strong, cultivated, different and a probable threat the West started to be associated with negative ethical characteristics; this was a new phenomenon. This change is best seen in the development of the Turkish novel. Until 1910 the leading novelists of the Ottoman period aimed their criticism not at the 'West' itself, but only at the Turks and Muslims who imitated and tried to look like westerners. There is, however, a sudden change after 1910 around the time when the nationalist Young-Turks came to power. A new generation of writers appeared, presenting a new image of the westerners: negative personalities such as violent and dishonest men or shameless women seducing and betraying the Turkish characters. The dishonest and expansionist 'West' as a whole came to be presented as the cause of many national sufferings and as a threat to Turkey. That was the message of hundreds of literary texts of this kind. ${ }^{32}$

Naturally the Turkish novel and Turkish literature overall does not consist only of this kind of stories. The general perception of the West, however, remained that of a political enemy (among nationalists), a moral threat (among Islamists) or a colonial/imperial hegemon (among the Left). The East-West metaphor governed it all. The 'West' is spiritually unsound, it is individualistic and selfish, modern but corrupted, indulgently permissive to the detriment of sound ethical traditions and values. The belief that the technology of the West is needed, but that its culture is noxious continues to be widely heard. The following illustrative examples are from two recent articles, published in the Turkish media, the first condemning the West, the second analysing the situation:

$31 \quad$ See Ünüvar (2002), pp. 28-35.

32 See Millas (2001); Millas (2005a); Millas (2005b). 
There is no doubt that the modern version of anti-westernism is expressed as anti-Americanism [...]. This is so because the USA is the leader of the West. [...] The reason of the anti-western movement is the expansionist policy of the West that continues from the oldest times of history until today $[\ldots]$. The west has double standards $[\ldots]$ and has a negative image of Islam. ${ }^{33}$

The perception of the West has completely deteriorated lately in Turkey. A great section of the people believes that the West is a demon that has collaborated with the powers that tried the coup d'état [on 15 July $2016, \mathrm{HM}]$ and that wants to break the country apart. The West is seen as a single homogeneous body and as a source of ills. As a consequence the people do not want to listen to any criticism that comes from the West, even if this is justified. On the other hand the number of those who want new alliances with any power apart from the West is increasing. ${ }^{34}$

\section{$4 \quad$ Contradictions and Elisions}

There are various contradictions and elisions in the Greek and Turkish positions vis-à-vis the West and/or Europe:

1. Both claim that they are part of Europe. Especially many Greeks believe Europe without Greece is an oxymoron since even the name of the continent is Greek and the 'spirit' of modern Europe is based on the revival of Ancient Greece through the Renaissance. In Turkey the official and widely supported view is that the Turks have become part of the history of Europe since the time of Sultan Mehmet II (1432-81) and Sultan Süleyman (1494-1566), and that they have always been in touch with the developments of the West. However, when the Greeks and Turks use the terms 'Europe' and 'West' they also mean a number of countries in the west which are different from them. Europe is spoken of both as an extension of, and as an opposition to their own national identity.

2. The geographic use of the word 'West' raises the anticipation of its antonym East. But while denouncing the West, neither Greeks nor Turks associate themselves with the 'East' or any 'eastern' country. Indeed they would reject, sometimes indignantly so, a characterisation as 'oriental'. Turks resist being associated with Iran and other (Arabic) 'eastern' coun-

\footnotetext{
33 Altun (2017).
}

34 Coşkun (2016). 
tries. Greeks by the same token refuse to be associated with an 'eastern' country like Turkey, whom in fact they are intransigently set against. Thus the very idea of an 'East versus West' discourse collapses in on itself. For Greece, Turkey is East and Italy is West. For Turkey, Greece is West and Syria and Iran are East. Neither considers itself Eastern. While both countries see a West and an East, they do not see themselves as belonging to either of these two categories. Where do they belong, then? An acceptable answer would be that they see themselves to be simply 'anti-Westerners'. Or both, but separately, at the centre of the world.

3. There is a subsidiary East-West conflict between Greece and Turkey. Greeks believe that they are 'Europeans' when they compare themselves with 'eastern' Turkey; and Turks perceive Greece to be part of a 'European conspiracy' when they envisage future threats from 'western powers'. This ambiguity exists even though Greece and Turkey are allies within NATO. Thus both countries, both positioned against both West and East, are also positioned against each other within an East-West context.

4. There is an unresolved ambivalence concerning the pros and cons of Europe. Turkish reforms starting from the early nineteenth century were initiated under the banner of 'westernisation', but simultaneously triggering anxiety at the baleful influence of European 'culture' and lifestyle. Greece, too, followed 'western' political models and 'way of life', but to a considerable extent also stressing the importance of preserving the national character of Greek society. Is it desirable or is it harmful to be like the West and Europe? The question remains unresolved. The West is supposed to be against 'our culture', but it is still followed and imitated.

5. There is an unresolved ambivalence concerning the political and military relationship with the 'West'. Both in Greece and in Turkey it is widely believed that the 'West' is favouring the Other, 'our enemy', Turkey and Greece, respectively. Greeks accuse the West of selfishly reneging on its duty to stand by its ally, Turks accuse the West of anti-Islamist favouritism for Greece.

6. Both sides explain and justify their anti-Western/anti-European positions with a recourse to history. The problem with the historical argument is that, while the examples of past enmity are real, they are selectively chosen and partially presented. Instances of European support are passed over in silence, such as the European support for the Greek War of Independence in the 1820s, French and Italian neutrality in support of the Turkish War of Independence in 1923 and NATO support against the USSR in the Cold War. Instead, history is skewed to blame the Other. 
7. The negative aspects of the 'West' are raised or dropped as suits the occasion. When bilateral relations are harmonious, the past and the 'character' of the Other are shown in a positive light, or neutrally. When problems occur the accusatory repertoire is re-activated. These ups and downs are themselves 'explained' by 'history' too: a historical 'friendship' or an 'enmity' is recalled according to the needs of the moment. The 'character' of Europe reflects the political attitudes of the moment. The image of Europe was positive during the years 2002-2008 in Turkey but turned negative later; and likewise the Greeks suddenly remembered the 'hypocrisy' of the West and of the Germans when they were asked to pay back state loans.

8. The discourse is often at variance with actual events. The theme that the 'West' is against Turkey because of Christian prejudices of the Christians vis-à-vis Muslims was formulated at a time when Muslims in the Middle East were involved in fierce internecine and religiously motivated strife. This intra-Islamic clash is much more cruel and bloody than anything that is denounced in the relationship between the so-called East and West. Similarly, tensions between Sunni and Alevite Muslims within Turkey are much more pronounced than any real or imagined East-West controversy.

All these contradictions signal the necessity not to take the anti-European discourse at its face value. The terms 'West' and 'Europe' do not have definite meanings, are volatile and emotive terms, understood differently by different people in Greece and Turkey; and their meanings change in time, too, contingently. They serve a purpose, though, and that is why they exist. The most common use of these terms is to blame the Other: to a power that is seen as an enemy, as a rival, as a threat.

The terms 'Europe' and 'West' are preferred to specific names of countries by virtue of their very vagueness. A term that evokes a large number of opponents suggests, on the one hand, that the adversary is mighty, while, on the other hand, 'we' too can stand up to them. Rhetorically, 'Europe is against us' is more effective than 'Germany is against us'. The use of a vague term like 'West' is also a diplomatic way to state complaints and accusations indirectly and without escalating a controversy with a specific country or group of countries. 'Westerners are hypocrites' is more allowable than 'the French are hypocrites.'

The terms Europe and the West recall and reactivate the past. They remind 'us' of our old historical enemies (be they real or constructed), and remind the Other of his ancient guilt such as the colonial past, and frame the present in 
the cognitive comfort zone of century-long stereotypes and prejudices, dating back to old religious conflicts.

This discourse has all the hallmarks of classical nationalist ideology and argumentation: It is xenophobic, proclaims one's own moral superiority over inferior foreigners, frames modern relations in the putatively timeless essence of eternal national characters, and imputes, by an act of projection, whatever enmity is involved wholly to the Other's malice.

When all these contradictions and ambiguities are taken into consideration, one may be tempted to conclude that the anti-Western/anti-European discourse is used tactically as a political rhetoric: to voice complaints and demands. 'You do not accept a cut on our debt', or 'You do not accept us in the EU'. Such accusations bespeak a victimised self-image and a national identity in anguish: 'We are being treated unjustly, humiliated', etc. Used opportunistically, either to demand 'understanding' and 'compassion' for 'our shortcomings' and some other times to ask for help, this rhetoric operates as a defense mechanism against criticism - saying 'but you have done worse things' - and as a justification for demands - saying 'you owe something to us; you have to make amends.' All anti-Western discourses indirectly and eventually express a request.

There is also another way to account for this aggrieved sense of Eastern victimhood. In the less developed (industrialised and democratisedised) countries outside North-Western Europe, capitalism was introduced as an 'imported' foreign phenomenon. Anti-capitalist reactions, which in Western Europe found outlets in the form of Romanticism and socialism, could in South-Eastern Europe take the form of resistance against a foreign, 'Western/ European' way of life. Indeed all anti-Western criticism is characterised by nostalgic conservatism and an emphasis on wholesome home-grown traditions. Anti-Western discourse in Greece and Turkey corresponds - by analogy - to the conservative (anti-capitalist) discourse of the industrialised countries of the nineteenth century.

This 'Eastern reaction' to modernism is reflected in the different socialist discourses, too. In the 'West' the fight for socialism is expressed as an anti-capitalist movement; in Greece and Turkey this reaction is mostly directed against 'imperialism'. In other words, what in the 'West' is experienced as class grievances is voiced in Greece and Turkey as anti-Western grievances.

Anti-western nationalism is somehow different from the original nationalism of the west. First, it is late by two or three centuries. Second, the modernisation 
process in countries that invoke it is less advanced than in the early nationalist countries. This economic difference creates the self-image of being non-Western (and non-Eastern as well) and having a Balkan and maybe a Near-eastern identity; or an identity associated with a non-Western religious tradition such as Islam and Orthodoxy.

Differences in religion and culture do not in themselves create the tension. The tension is created by rising nationalism and the attendant antagonism between Self and Other. In Greece and Turkey, anti-western discourse is almost always associated with emerging or current nationalist ideals.

Naturally (and fortunately) not all Greeks and Turks share the same ideas and attitudes. One encounters firmly pro-European views and critiques of phobic nationalism. To interpret anti-westernism in an essentialist manner as a 'clash of civilisations' and to underestimate its ideological (nationalist) nature may operate as self-fulfilling prophecy: The beliefs and the perceptions may turn into real actions and situations.

Apart from our image of the Other, the image that we have of the Other's image vis-à-vis us is of paramount importance in the case of mutual antagonisms as with Greeks and Turks. They are very keen to see how the Other sees them; and they develop a new image: the meta-image of how the Other sees them. ${ }^{35}$ This image at present is negative. The Greeks believe that 'Westerners' consider them lazy, extravagant, easy going and worse: unworthy and insufficiently civilised descendants of their ancient ancestors. Turks also think that the image of the Europeans about them is very negative: Easterners, aliens to European values and culture, historically and religiously associated with despotism and terrorism. Such meta-images are deeply hostile to the Other while imputing that same hostility to the Other; it cannot but be detrimental to the relations between nations. To control accusatory discourses and to recognize whatever is good in the Other would be a more helpful and constructive approach for all parties concerned.

\section{Bibliography}

Altun, Fahrettin (2017). "Batı Karşıtlı̆̆ı" Niçin Anlamlıdır?' [Why is anti-westernism meaninful?], 26. January, Yeni Şafak. https://www.sabah.com.tr/yazarlar/fahrettinaltun/ 2015/o1/26/bati-karsitligi-nicin-anlamlidir [accessed 11.05.2019].

For the concept of meta-image see Leerssen (2016). 
Bora, Tanıl (2002). 'Millıyetçi-Muhafazakâr ve İslamcı Düşünüşte Negatif Batı İmgesi' [The Negative Image of the West in Nationalist-Conservative and Islamist Thought], in Uygur Kocabaşoğlu (ed.), Modern Türkiye'de Siyasi Düşünce. Modernleşme ve Batıcılı [Political Thought in Modern Turkey. Modernization and Westernization], vol. 3 (Istanbul: İletişim), pp. 251-268.

Buruma, Ian, Avishai Margalit (2005). Occidentalism. The west in the eyes of its enemies. (London: Penguin Books).

Carrier, James G. (ed.) (1995). Occidentalism. Images of the West (Oxford: Clarendon Press).

Coşkun, Vahap (2016). 'Turkey after 15 of July', 15. July, Serbestiyet website [accessed 15.01.2017]. The url for this website is no longer available.

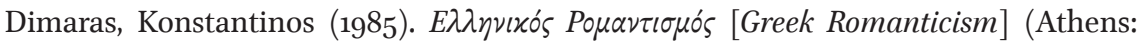
Ermis).

Erdogan, Recep Tayyip (2017). 'Speech by Turkish President R. T. Erdogan to Turkish Governors in Ankara', 9 January, Milliyet, 10 January.

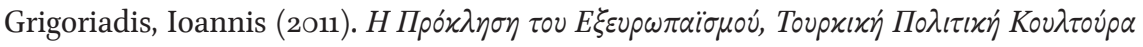

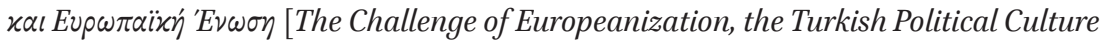
and the European Union] (Athens: Sideris).

Grigoriadis, Ioannis (2013). Instilling religion in Greek and Turkish Nationalism (London: Palgrave Pivot).

Gökalp, Ziya (199o). Türkçülügün Esasları [The Principles of Turkishness](Ankara: Milli Eğitim Yayınları).

Haber 3 (2015). 'Türkler AB'ye girmek istiyor mu?' [Do Turks want to join the EU?], 9 April. http://www.haber3.com/turkler-abye-girmek-istiyor-mu-3305463h.htm [accessed 03.09.2017].

Hanioglu, M. Şükrü (2008). A Brief History of the Late Ottoman Empire (Princeton, Oxford: Princeton University Press).

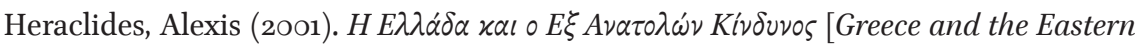
Danger] (Athens: Polis).

Iefimerida (2015). 'Epistoli tis proedrou tou Areiou Pagou se Evrapeous dikastes. $\mathrm{Na}$ ti theli o ellinikos laos' [The letter of the President of the Supreme Court. Let me explain what the Greek people want], 9 July. http://www. iefimerida.gr/ news/216356/epistoli-tis-proedroy-toy-areioy-pagoy-se-eyropaioys-dikastes-na-sasexigiso-ti-thelei-o [accessed 03.09.2017].

Internet Haber (2016). 'Türkiye AB'ye girmek istiyor mu, şok anket' [Does Turkey want to join theEU? shocking polls], 16 June.http://www.internethaber.com/turkiye-avrupabirligine-girmek-istiyor-mu-sok-anket-16o6o93h.htm [accessed o3.o9.2017].

Karaiskos, Apostolos (2016). 'Sionismos ke Pagosmiopiisi' [Zionism and Globalisation], 1 October. http://www.xryshaygh.com/ [accessed 17.03.2017]. 
Karaiskos, Thanasis (2016). 'The heartbreaking nightfall of the West', 25 April. https://syrizazante.workpress.com [accessed 17.03.2017].

Katsaros, Dimitris (2014). 'To Islamiko kratos, I Disi ke to KKE' [The Islamic State, the West and the KKE/Greek Communist Party]. http://www.rizopoulospost.com/toislamiko-kratos-h-dysh-kai-to-kke/ [accessed 17.03.2017].

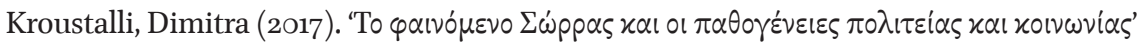
[The Sorras phenomemon and the pathogenesis of state and society], To Vima, 7 January. https://www.tovima.gr/2017/o1/o6/politics/to-fainomeno-swrras-kai-oi-pathogeneies-politeias-kai-koinwnias/ [accessed o3.09.2017].

Leerssen, Joep (2016). 'Imagology. On Invoking Ethnicity to Make Sense of the World', Iberic@l. Revue d'études ibériques et ibéro-américaines, 10, pp. 13-31.

Metallinos, Georgios (1988). Tourkokratia [Turkish Rule] (Athens: Akritas).

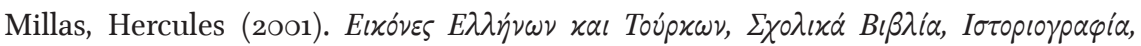

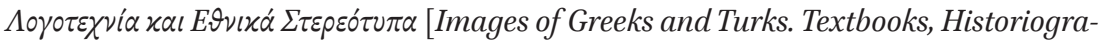
phy, Literary Texts and National Stereotypes] (Athens: Alexandria).

Millas, Hercules (2005a). Türk ve Yunan Romanlarında Öteki ve Kimlik [The Other and Identity in Turkish and Greek Novels] (İstanbul: İletişim).

Millas, Hercules (2005b). 'The Other and Nation Building. The Testimony of Greek and Turkish Novels', in Nedret Kuran-Burçoğlu, Susan Gilson Miller (eds), Representations of the 'Other/s' in the Mediterranean World and Their Impact on the Region (İstanbul: The Issis Press), pp. 141-148.

Millas, Hercules (2006). 'Tourkokratia. History and the Image of Turks in Greek Literature', South European Society and Politics, 11.1, pp. 47-6o.

Millas, Hercules (2008). 'History Writing among the Greeks and Turks. Imagining the Self and the Other', in Stefan Berger, Chris Lorenz (eds), The Contested Nation. Ethnicity, Class, Religion and Gender in National Histories (New York: Palgrave MacMillan), pp. 490-510.

Pew Global Studies survey 2014 (2014). https://www.pewglobal.org/2014/o7/14/globalopposition-to-u-s-surveillance-and-drones-but-limited-harm-to-americas-image/ [accessed 17.03.2017].

Palmos Analysis (2016). 'Dispistoi oi Ellinew apenanti stous evropaikous thesmoous'. [Greeks skeptical vis-à-vis the European institutions], Aixmi.gr, 18 December. https://www.aixmi.gr/index.php/palmos-analysis-dyspistoi-oi-ellhnes-apenantistoys-eyrvpaikoys/

Said, W. Edward (1994). Orientalism (New York: Vintage Book).

Todorova, Maria (2009). Imagining the Balkans (Oxford: Oxford University Press).

ToVima (2016). 'Judges and public prosecutors. Greece is not the economic guinea pig of Europe, 8 February. https://www.tovima.gr/2016/o2/o8/society/dikastes-kai-eisagget leis-i-ellada-den-einai-to-oikonomiko-peiramatozwo-tis-eyrwpis/ [accessed o3.o9.2017]. 
Voria.gr (2016). 'The hypocrisy of the West is ending, the events with Erdogan now begin', 24 July. http://www.voria.gr/article/i-ipokrisia-tis-disis-telioni-ta-gegonoł ta-me-ton-erntogan-tora-archi [accessed 17.03.2017].

Ünüvar, Kerem (2002). 'Ziya Gökalp', in Tanıl Bora (ed.), Modern Türkiye'de Siyasi Düşünce, Milliyetçilik [Political Thought in Modern Turkey, Nationalism], vol. 4 (Istanbul: İletişim), pp. 28-35.

Zürcher, Eric Jan (2004). Modernleşen Türkiye'nin Tarihi [Turkey. A Modern History] (Istanbul: İletişim). 


\title{
The Image of the Wall
}

\section{The Antemurale Christianitatis Myth from an Imagological Perspective}

\author{
Zrinka Blažević
}

\begin{abstract}
The interpretative focus of this contribution is on the antemurale Christianitatis myth, which is one of the most durable historical myth-symbol complexes typical for the heterotopic cultures of the European periphery. Its first part highlights the epistemological status and imago-generative quality of historical myths within the theoretical framework of historical imagology. In the second part, the analysis focusses on the multiple uses, functions and meanings of this antemurale Christianitatis myth within Croatian culture over a long historical period. Special attention is paid to detecting how it simultaneously functions both as a rich repository of auto- and hetero-images as indispensable means for symbolic construction of collective identities and as a vital part of Croatian social imagery and cultural memory. Together with its structural and functional features, the modalities of intertextual, interdiscursive and intermedial circulation of the antemurale Christianitatis myth are also examined. In this way, light is shed on the extraordinarily high ideological and political potential of the antemurale Christianitatis myth which could be reactivated at any time, for example as a consequence of migration pressures on the Balkan route.
\end{abstract}

\section{Introduction}

These days, when the American president puts all his efforts into building an "impenetrable, physical, tall, powerful, beautiful wall" along the US-Mexican border, ${ }^{1}$ and the eastern borders of the Schengen area have been protected by metal fences and razor wire, the image of the wall ceases to be a pure historical reminiscence of chivalric medieval times or a sentimental cultural reference

1 As a Republican presidential nominee, Donald Trump described his proposed wall along the Southern U.S. border during an immigration policy speech on August 31, 2016. See: https://www.washingtonpost.com/video/politics/trump-says-he-will-build-impenetrable-physicaltall-powerful-beautiful-border/2016/o8/31/34eceacc-6fb6-11e6-993f-73c693a8982o_video. html?utm_term=.5c9945d9eb28 [accessed 05.09.2017]

(C) ZRINKA BLAŽEVIĆ, $2021 \mid$ DOI:10.1163/9789004436107_010

This is an open access chapter distributed under the terms of the CC BY-NC-ND 4.0 license. 
to the legendary Pink Floyd album. It is no wonder that the image of the wall gains its currency in Croatia, one of the newer EU members and one of the most exposed countries on the Balkan refugee route, since it is one of the most vital elements of the antemurale Christiantitatis myth, which has played an indispensable role in the historical imagery and cultural memory of Croatia. ${ }^{2}$ This paper will therefore scrutinize more closely this mythical-symbolic complex from the imagological perspective.

Regrettably, literary imagology has not focused enough analytical attention on historical and political myths despite their decisive role in the construction of the self-image of communities. ${ }^{3}$ Recent imagological research on historical mythology of the European nations is mostly concerned with the structural elements of the mythical narratives, such as historical and allegorical mythical figures, the characteristics of their medial representations and the functions of myths within the national memory. ${ }^{4}$

\section{The Functioning of Historical Myth}

For the purpose of this analysis, I will outline a provisional theoretical and methodological scheme for the research of historical myths. As a heuristic platform profoundly suitable for scrutinising complex imagemes such as historical myths, I would propose a framework of historical imagology which operates with a broader concept of image. The image is defined as an interferential configuration of mental images, textual and non-textual representations and practice patterns which are constituted within a certain socio-historical context. Seen from the perspective of that subtle dialectics of structure and agency or objectification and embodiment, an image could appear as a constitutive part both of collectively disposable cultural imagery and individual experience of the world. Accordingly, images can be understood not only as cognitive and perceptive products of the human brain or various kinds of visual representations, but also as formative elements of all cultural imaginaries, i.e. systems

2 This fact was recognised during the 199o's by the most prominent Croatian philosophers and sociologists who extensively wrote about the antemurale myth (See e.g. Paić (1997), Žanić (1999)). Surprisingly enough, the antemurale Christianitatis myth has not attracted any interest of Croatian historians, not to mention imagologists, although it may be an inexhaustible source both for the historical and imagological research.

3 For a brief overview on the research of myths in literary history and historiography see Beller (2007), pp. 373-376.

4 See Beller (2007), p. 375 . 
of signs and/or thoughts with ideological, axiological and affective potentials which represent imaginational possibilities of a culture in a certain period. ${ }^{5}$

The proposed conceptualisation is in many aspects congruent with the theory of political myth recently launched by the Italian philosopher Chiara Bottici. Accentuating praxeological and phenomenological approaches as foundations for her theoretical conceptualisation, Bottici defines political myth as a complex narrative which coagulates and produces significance shared by the group by virtue of addressing the specific political conditions in which the group operates. ${ }^{6}$ Although political myth shares many structural and functional features both with historical narratives and other kind of myths (natural, religious, foundational myths etc.), Bottici argues that it can be treated as a specific category thanks to its inherent capability to inspire and prompt political action. ${ }^{7}$ This capability of political myth is possible due to its ability to generate imaginary significations which Bottici, following the theory of the social imaginary by French philosopher Cornelius Castoriadis, regards as an indispensable element for the constitution and functioning of each society. 8

Inspired by the theoretical presumptions of Hans Blumenberg, Bottici deems political myth not a final product, but a process of continual reworking

5 For a more detailed account see Blažević (2012), pp. 105f.

6 See Bottici (2007), p. 18o.

7 See Bottici (2007), p. 216.

8 Beside his inspiring influence on the philosophy of political myths, Cornelius Castoriadis's work has many possible incentives for imagological research as well. According to his quite radical imagocentric theory, social imagery itself possesses an ontological priority vis-a-vis both reality and society: "The social world is, in every instance, constituted and articulated as a function of such a system of significations, and these significations exist, once they have been constituted, in the mode of what we called the actual imaginary (or the imagined). It is only relative to these significations that we can understand the 'choice' of symbolism made by every society, and in particular the choice of its institutional symbolism, as well as the ends to which it subordinates 'functionality'. Incontestably caught up in the constraints of the real and the rational, always inserted in a historical continuum and, consequently, codetermined by what was already there and cannot be freely manipulated, the production of these significations cannot be exhaustibly reduced to one of these factors or to all of them together. This cannot be done because none of these factors can fill the role of these significations, none can 'answer' the questions that they 'answer'. [...] In the same way, every society defines and develops an image of the natural world, of the universe in which it lives, attempting in every instance to make of it a signifying whole, in which a place has to be made not only for the natural objects and beings important for the life of the collectivity, but also for the collectivity itself, establishing, finally, a certain 'world-order'. This image, this more or less structured vision of the whole of available human experience, makes use in each case of the rational lines of what is given, but arranges them according to and subordinates them to significations which themselves do not belong to the rational order (nor, moreover, to a positive irrational order) but to the imaginary." Castoriadis (1997), p. 146 and 149. 
of the basic narrative core of mythologem, which is endowed with cognitive, practical and aesthetical dimensions. ${ }^{9}$ In order to provide functional cognitive schemata for mapping the social world by reducing the complexity of social life, as well as to mobilize people for social action, political myths are usually represented in a dramatic form, evoking a kind of pathos. ${ }^{10}$

According to Bottici, important features of political myths are their positional character, multimedial appropriateness and condensational power. In other words, they are always constructed from the standpoint of the present and they are appropriate for representation in various media: textual, visual, audio and performative ones. ${ }^{11}$ Thanks to the ubiquity of potential medial conveyors of political myths under the contemporary conditions of globalised spectacle, they can cause "the primacy effect" more easily than ever. ${ }^{12}$ In addition to this, as Christopher G. Flood has convincingly demonstrated, political myths are endowed with a condensational power which refers to their capacity to condense things into a few images or "icons". ${ }^{13}$ For all these reasons, political myths are able to incite practical understanding which, recursively, strengthens their persuasive potential and, subsequently, their mobilising effect. ${ }^{14}$

In his famous work Arbeit am Mythos, Hans Blumenberg develops a processual approach to myths. In short, his main proposition is that a basic narrative core of the myth, a mythologem, must change over time to be appropriated by different requirements and exigencies in order to answer a need for significance. See Blumenberg (1979). See Bottici (2007), p. 181. Bottici (2007), p. 214.

12 Christopher G. Flood launched the term in order to stress that a person's earliest perceptions of a phenomenon function as a powerful basis for generalisations, categorisations and expectations that are not easily or adequately revised in the light of subsequent observations. The "primacy effect" is a distinguishing feature of political myths primarily due to their emotional appeal which leads to a narrowing of attention, with a consequent reduction of categories used for the interpretation of the phenomenon. For a more detailed account see Flood (2002), pp. $86 f$.

13 In his insightful analysis of structural and functional features of political myths, Flood points to the specific ability of images to evoke mythical stories. According to Flood, they do so in the following manner: a) by depicting particular, identified historical actors in particular, identified situations; b) by depicting particular, identified persons in stock, hypothetical, or imaginary situations; c) by depicting unidentified persons representative of a group in particular, identified, historical situations; d) by depicting unidentified, representative persons in stock, hypothetical or imaginary situations; e) by depicting allegorical figures or supernatural entities in identified historical situations; and f) by depicting allegorical or supernatural figures in stock, hypothetical or imaginary situations. See Flood (2002), pp. 167 f.

14 On practical understanding, which refers to the implicit, intuitive and embodied knowledge, as one of the key concepts of practice theory, see Schatzki (2001), pp. 10-18. 
As constitutive parts of a social imaginary, which Bottici, again following Cornelius Castoriadis, conceptualizes as a symbolic network of imaginary significations which provide social meanings, political myths might obtain both legitimising and critical functions. ${ }^{15}$ In this sense, political myths are similar to ideology viewed as a "a set of ideas by which men posit, explain and justify ends and means of organised social action, and specifically political action, irrespective of whether such action aims to preserve, amend, uproot or rebuild a given social order."16 However, the impact of political myths is in many cases superior to those of ideology thanks to the pathos evoked by their emotional and affective quality which makes them more appropriate means for political mobilisation. ${ }^{17}$ Finally, by virtue of their inherently plural nature which enables multiple identitary recognitions and juxtapositions, political myths are indispensable vehicles for constructing both individual and collective political and cultural identities. ${ }^{18}$ Or, as Chiara Bottici succinctly formulates, "as narrative which can coagulate and provide significance, political myth unifies all the various elements that constitute common identity which comes to be recognised and accepted by a plurality of living, acting and narrating bodies." 19

Although at first glance the antemurale Christianitatis myth belongs to the category of historical or even cultural myths, thanks to its inherent structural and functional characteristics it can also be regarded as a political myth par excellence. According to the distinction between these two categories made by Bottici, political myth, unlike historical with which it shares narrative form, has to be received as a drama which makes its moral explicit in order to prompt

\footnotetext{
15 See Bottici (2007), pp. 225f.

16 Flood (2002), p. 13.

17 See Bottici (2007), p. 196.

18 Bottici warns that every attempt to scrutinize the complex issue of identitary recognitions and juxtapositions must necessarily take into account the following relations: the relation of the singular human being with himself or herself; relations of different singular human beings with each other; relations between the same singular human beings with themselves in time, as well as the relations between them and a tertium (i. e. nation, gender or another social group) and even the relation of this tertium with itself. See Bottici (2007), p. 235.

Bottici (2007), p. 243.
} 
political action. ${ }^{20}$ Since the antemurale Christianitatis myth has been one of the key factors of the Croatian "identitary battles" for almost half of a millenni$u m,{ }^{21}$ its political connotations and mobilising power are more than obvious. Therefore, the following imagological analysis of the antemurale Christianitatis myth will be situated among the proposed theoretical coordinates which seem appropriate enough to examine its cognitive and explanatory values.

The metaphor of "the bulwark of Christendom" was a flattering epithet for the French defenders of Edessa which had been coined in the twelfth century by Bernard of Clairvaux (1090-1153), a fervid preacher of the Second Crusade. It became a fairly widespread syntagm in the fifteenth and sixteenth centuries when Ottoman incursions reached their peak. It originated in the prophecies of the Old Testament, i.e. in the Book of Praise, where the prophet Isaiah envisaged the destruction of Moab, ${ }^{22}$ and has been an indispensable element of the rhetoric of the Crusades. Therefore, it could easily be adapted to the circumstances of the Ottoman threat within the early modern European political imaginary, which was deeply imbued with religious symbolism.

In order to symbolically compensate for the military efforts in defending Christianity as well as to exculpate themselves for not providing sufficient material assistance, European secular holders of power attributed this fashionable nickname to Croatia, Hungary and Poland, which were situated on the first line of the anti-Ottoman defence. Soon the nickname developed into a powerful element of these countries' self-description and a potent mythologem which abundantly fuelled their respective national mythomoteurs. ${ }^{23}$

As far as the Croatian historical imagery is concerned, the first mention of the antemurale Christianitatis title was linked to the sacral and moral authority of Pope Leo X (1475-1521). After hearing a report on anti-Ottoman battles in Croatia submitted by the Tragurian bishop Thomas Niger, the pope in the consistory held on 12 of December 1519 allegedly named Croatia "scudum solidissimus et antemurale Christianitatis" i.e. "the strongest shield and bulwark of

$20 \quad$ See Bottici (2007), p. 216.

21 Žanić (2003), p. 161.

22 See Isaiah 26.2.

23 The nickname of bulwark and shield of Christianity were attributed to Hungary and Croatia for the first time by the Hungarian kings Vladislaus I (1424-1444) and Vladislaus II (1456-1516) Jagiellon in the second half of the fifteenth century. Afterwards it was used by Maximilian I (1459-1519) and Ferdinand I (1503-1564) of Habsburg to accentuate the importance of Croatian lands for defending the eastern borders of the Holy Roman Empire. In Poland the motif of antemurale Christianitatis was especially popularised during the seventeenth century by the authors of Polish Sarmatism (e. g. Wespazjan Kochowski in his Polish Psalmody published in 1695). See Žanić (2003), pp. $164 f$. 
Christendom". ${ }^{24}$ Although not corroborated by historical evidence, this fancy metaphor was rapidly appropriated by numerous Croatian humanists and diplomats such as Count Bernardin and Krsto Frankopan. ${ }^{25}$ They used it mainly as a powerful tool for legitimising the claiming of military subsidy from the Roman popes and Habsburg Emperors during the first half of the sixteenth century. ${ }^{26}$

In addition, during the early modern period the antemurale mythologem was simultaneously integrated into the elite political discourse and turned into an indispensable element of the chivalric and heroic self-image of the Croatian nobility. ${ }^{27}$ In order to enhance its mobilising value and emulative potential, it was hypostatised in the heroic figure of Nikola Šubić Zrinski (1508-1566), the "Croatian Leonidas". He was a famous Croatian viceroy and nobleman who was murdered as a martyr while defending the fortress of Szygetvár from the copious Ottoman army led by the sultan Suleiman the Magnificent (1494-1566) in $1566 .^{28}$

24 Šanjek (1993), pp. 351f.

25 Count Bernardin Frankopan (1453-1529) delivered his "Speech for Croatia" in Latin language at the Diet of the Holy Roman Empire on 19 November 1522 in Nürnberg, while his son Krsto (1472-1527) addressed his memorandum on Croatia, dated 1 July 1523, to Pope Adrian VI (1459-1523).

26 E. g. the fragment of Krsto Frankopan's memorandum addressed to Adrian vi: "There is no word which can describe how crudely and under worst penances our people were treated under the most cruel Turkish yoke and violence. Holy Father, in Croatia can be seen children who are slaughtered in front of their parents' eyes and men in front of eyes of their wives. Wives are dishonoured, virgins raped, sacred places and priests desecrated. Holy Father! Croatia is a bulwark and shield of Christendom, especially of border provinces such as Carinthia, Carniola, Istria, Friuli and Italy. If Croatia - God forbid - would be occupied, all of the above mentioned torments would endanger its neighbouring provinces and there would be a clear and open way for the Turks." Gligo (1983), p. 356 . [Translations by the author].

27 For a seventeenth century example of the literary construction of the heroic Croatian self-image see Blažević (2010), pp. 35-42.

28 The siege of Szygetvár was first described by Ferenc Črnko, a scribe and chamberlain of Nikola Šubić Zrinski, who was an eyewitness of that battle. After the fall of Szygetvár, Črnko was captured by the Turks, but he was eventually bought out by Nikola's son Juraj. Under his influence, Črnko wrote a literary chronicle on the battle of Szygetvár in Croatian, which was translated into Latin by Slovenian writer Samuel Budina in 1568 and thus became a pretext for the later works dealing with this famous episode. The siege of Szygetvár was especially popularised in the seventeenth century by Nikola Zrinski's great-grandson Nikola VII (1620-1664), the author of the famous epos Adriai tengernek Syrenaia (published in Hungarian in 1651), which was subsequently translated into Croatian and published by his brother Petar IV (1621-1671) under the title Adrianskoga mora sirena in 166o. They might be considered the founders of the Nikola Šubić Zrinski myth 
During the period of the Croatian national movement in the nineteenth century, the antemurale Christianitatis myth encountered a significant modification in order to adapt to the new political circumstances and ideological needs. The role of the Croatians as traditional guardians of the Western civilisation was projected back to the thirteenth century when, according to the legend, the wild hordes of Tatars were defeated by the intrepid Croatian army in the field of Grobnik near the town of Rijeka in $1242 .{ }^{29}$ Together with the important "antiquation-effect", 30 which situates the Croatian bulwark function even in the pre-Ottoman times, the nineteenth-century version of the myth brought forth new enemies - the barbarous Tatars - who were symbolically identified with the Hungarians, the main political and ideological rivals of the Croats in that period. ${ }^{31}$

The rise of various Slavophile ideologies in the second half of the nineteenth century brought about a kind of antemurale counter-myth. It absorbed its ideological potential from the historical episode of the pan-Slavic Christianisation project by S. Cyril and Methodius which took place in the ninth century. ${ }^{32}$ In contrast to the impermeable and exclusionary character of the wall, the new myth envisaged Croatia as a permeable civilisational bridge or

which simultaneously played an important role as a strategy of the noble representation of the family and as a cornerstone of the Croatian national identity and cultural memory. See Blažević, Coha (2007), pp. 137-164. On later appropriations and literary representations of the Zrinski myth in Croatian, Austrian and Hungarian cultures see Kovács (2015), pp. 83-100.

29 Although the legendary battle of Grobnik between Tatars and Croats was first mentioned in the Chronicle published by Croatian historiographer Pavao Ritter Vitezović (1652-1713) in 1696, it became an indispensable part of Croatian national memory primarily thanks to the romanticist poem The field of Grobnik published by the poet Dimitrije Demeter (1811-1872) in the Croatian literary journal Kolo in 1842. For a synthetic overview see Rapacka (2002), pp. 7of.

See Stergar (2016), pp. 96-99.

$31 \quad$ See Rapacka (2002), p. 71.

32 The cult of S. Cyril (826/827869) and Methodius (before 815-885), known as the 'apostles of the Slavs', who translated the Bible into the Church Slavonic language and invented the Glagolitic and Cyrillic alphabet, has been abundantly documented in Croatia since the medieval period. However, it gained a new popularity in the nineteenth century when it was used as a legitimising idea for the political unity and cultural identity of the Slavs in the Austro-Hungarian Monarchy as well as an important factor of distinctive Slavic national ideologies, including the Croatian one. The main promotors of their cult in Croatia were bishop Josip Juraj Strossmayer (1815-1905) and historian Franjo Rački (1828-1894). As an important nineteenth century Croatian mythomoteur, the cult of S. Cyril and Methodius serves to promote and legitimize Yugophile ideas of South Slavic cultural, political and religious unity, but also functions as a proof of the national character of the universal Catholic church. For a more detailed account see Rapacka (2002), pp. 35-37. 
crossroads. In this way it enhanced the images of Croatia's religious and cultural heterogeneity and plurality not only as acceptable, but also as distinctive markers of its identity. ${ }^{33}$

In the course of the turbulent twentieth century, both versions of the Croatian auto-mythologems lived on, confronting, intertwining but always conforming to the various ideological purposes and political needs. The classical variant of the antemurale myth was mainly nurtured and reproduced within the conservative and clerical political discourse, ${ }^{34}$ while its counter-myth retained its popularity predominantly among leftist and Yugophile political circles. ${ }^{35}$ The most interesting example of the ideological adoption of the antemurale myth for the anti-Soviet political platform of Josip Broz Tito stems from the beginning of the 1950's, when Yugoslavia was pompously proclaimed "a rock which defends the democratic West." ${ }^{36}$ However, a more widespread antemurale metaphor during the socialist period included images of Yugoslavia as "a bastion of self-managing socialism" and a "fortress of the brotherhood and unity."37

As could be expected, the new revival of the antemurale myth with its entire symbolic repertoire has occurred under Tuđman's regime during the 199o's. Moreover, its ideological content was slightly modernised, so that the standard religious symbolism was enriched with a Huntingtonian dash of 'civilisational clash'. Accordingly, faced with the military threat from Belgrade, the young and independent Republic of Croatia was again promoted to the bulwark of Western Christianity, civilisation and democracy against the contemptible Eastern

33 See Žanić (2003), p. $176 f$.

34 The most prominent propagators of the classical version of the antemurale myth were, among others, the bishop of Krk Antun Mahnič (1850-1920), the Jesuit philosopher and publicist Fran Bitnički (1875-1945) and the geographer Filip Lukas (1871-1958). After the Second World War, members of the Croatian radical political emigration revived the antemurale myth once again in order to mobilize Western countries against the new Yugoslav state. In 1953 they issued a postage stamp which iconographically represented the main elements of their revisionist political ideology: the Croatian historical coat-ofarms, a portrait of cardinal Alojzije Stepinac, who was sentenced by the communist government, a map of Croatia in its maximised 'natural' borders and a baptistery of count Višeslav from the ninth century as a symbol of Croatian Christian identity, with the overarching title Antemurale Christianitatis - Pope Leo X 1519. For a more detailed account see Žanić (2003), pp. 184-187.

This trend was especially reinforced after 1980 when Pope John Paul II declared S. Cyril and Methodius "co-patrons of Europe". For a more detailed account see Žanić (2003), 189 f.

36 Cited in Žanić (2003), p. 187. This statement was launched by Josip Broz Tito during his speech delivered in Slovenia in September 1952, in the middle of the so-called Trieste crisis.

Žanić (2003), p. 188. 
Orthodoxy, uncivilised Byzantinism and Communism. Interestingly enough, until 1993 and Tuđman's break with his Muslim allies in Bosnia, and for reasons of political correctness, the preferred version was the 'Grobnik version' of the antemurale myth with the Tatars in the role of the inimical Other. After 1993, the 'Grobnik version' of the antemurale myth was mostly used in its archetypal Islamic variant epitomised in the heroic figure of Nikola Šubić Zrinski, whose name was given even to the state decoration of the Republic of Croatia instituted for "heroic deeds in the war" by Franjo Tuđman in 1995. ${ }^{38}$

After Tuđman's death at the end of 1999 and the election victory of the Social Democratic Party in 2000, the antemurale myth and its bridge/crossroads counter-myth happily coexisted within the Croatian political discourse. Naturally, there has been a slight predomination of the one version or another depending on the conservative or liberal orientation of the currently ruling political establishment. ${ }^{39}$

As far as the classical antemurale myth is concerned, worth exploring are also its structural features and imago-generative mechanisms, which nurtured its ideological potency and political efficiency. Following Bottici's classification, its most striking feature is certainly the mechanism of coagulation. It is simultaneously realised on different structural, functional and semiotic levels, which greatly enhance its imagological value. First of all, it rests on the bonding of the positive auto-image (i.e. Croats) and negative hetero-images (Tatars or Turks), as well as on the intertwining of the sacral and military semantic fields. They are epitomised in the figure of the athleta Christi, i.e. an exemplary national martyr and a hero who sacrifices his life in the battle against the enemies of Christianity ${ }^{40}$ In addition to this, coagulation is realised in the form of the fusion of temporal horizons by constructing an imaginary analogy between the past and the present, which serves as a model for the future actions. At the most abstract level, there is the coagulation between the internal and the external. It produces a significant symbolic effect of including Croatia into the

\footnotetext{
38 For a more detailed account see Žanić (2003), p. 190-193.

39 See Žanić (2003), pp. $194 f$.

40 The exemplary model of heroic martyrdom of the athleta Christi is that of Nikola Šubić Zrinski, who proudly refused Suleiman's offer to surrender the fortress and personally led a breach from Szygetvár. For a detailed analysis of discursive constructions of heroic martyrdom of Nikola Šubić Zrinski see Blažević, Coha (2007), pp. 139-141.
} 
Western and Christian civilisation while simultaneously excluding it from the barbaric and infidel East.

An imago-generative quality of the antemurale myth is additionally bolstered by two complementary modes. One is a strategy of symbolic condensation, which refers to the structural capacity of a myth to condense its content into few images or icons. Without any damage to its semantic or ideological potentials, the antemurale Christianitatis myth can thus be reduced to an architectural element or a sign like a bulwark, fortress and wall, or to a historical person like Nikola Šubić Zrinski. Another one is a principle of symbolic extension by virtue of which particular persons, places or historical events might easily be generalised to designate entire nations, religions or civilisations, which is a basic strategy of construction of the Croatian national auto-image.

Furthermore, important features of the antemurale myth are its polysemic and multimedial qualities, which enable its highly successful intertextual, interdiscursive and intermedial circulation throughout its long historical duration. From the sixteenth century onwards, the antemurale myth has been articulated in various literary and documentary genres and visual arts and especially in nineteenth-century historical painting. ${ }^{41}$ A very convenient medium for reproducing the antemurale myth are musical works as well. Its most famous example is the monumental national opera Nikola Šubić Zrinjski composed by Ivan Zajc in $1876 .{ }^{42}$

The most representative example is certainly a painting entitled Antemurale Christianitatis by Ferdinand Quiquerez (1845-1893), a Croatian painter of French origin, in 1892. It is an allegory of Croatia fighting against the Turks. Croatia is represented as a young and beautiful woman crowned by laurels. She holds a flaming sword in her right hand and the Croatian coat-of-arms pinned by arrows in her left. Croatia stands on the monumental staircase and fights against the Turks who invade from below, while behind her back the most famous representatives of the Western intellectual and cultural life peek fearfully: Rafael, Dante, Michelangelo, Galileo, Moliére and Shakespeare. In the background the contours of the St. Peter's Dome can be seen, which clearly illustrates Croatia's role in defending European civilisational values.

42 The opera Nikola Šubić Zrinski (tragedy in three acts) composed by Ivan Zajc (1832-1914) after a libretto by Hugo Badalić (1851-1900) is doubtlessly the most popular Croatian musical work. From its premiere, which took place in the Croatian National Theatre in Zagreb in 1876, until the beginning of the 199o's it was performed around 2000 times, which is the best proof of its popularity. The best known element of the opera is a song $T o$ battle, to battle set to lyrics by Franjo Marković. It is no surprise that the heroic martyrdom of the athleta Christi Nikola Šubić, which strikingly resembles samurai values, has been recognised in Japan as well. The song To battle, to battle was performed by a Japanese choir which numbered 1000 men, conducted by maestro Katsuaki Kozai in Tokyo in 2006. For a more detailed analysis of the imago-generative potential of the opera within the Croatian national culture see Marković (2014). 
By functioning as a rich repository of axiologically and affectively imbued auto- and hetero-images, the antemurale Christianitatis myth is certainly one of the most enduring cornerstones of Croatian national identity. Moreover, thanks to its compensatory function, the image of a small, but heroic nation situated at the very of edge of Europe with a God-given mission to defend the Western civilisational values still ranks very high in Croatian national memory. A very frightening proof of that statement provides the anti-immigration propaganda of Croatian right-wing, conservative and clerical circles which invigorates historical myths of the heroic battle of Croatian priests against the Ottoman threat within the recent political context of "soft Islamisation" allegedly caused by too liberal immigration politics of European states. ${ }^{43}$

\section{Bibliography}

Beller, Manfred (2007). 'Myth', in Beller, Manfred, Joep Leerssen (eds). Imagology. The cultural construction and literary representation of national characters. A critical survey (Amsterdam, New York: Rodopi), pp. 373-376.

Blažević, Zrinka (2010). 'Ideae magnanimitatis Illyricae et Pannonicae. Héroïsme baroque et (de)construction de la mémoire nationale', in Baric Daniel, Jacques le Rider, Drago Roksandić (eds), Mémoire et histoire en Europe centrale et orientale (Rennes: Presses Universitaires de Rennes), pp. 35-42.

Blažević, Zrinka (2012). 'Imagining Historical Imagology. Possibilities and Perspectives of Transdisciplinary/Translational Epistemology', in Davor Dukić (ed.), Imagologie heute. Ergebnisse, Herausforderungen, Perspektiven / Imagology Today. Achievements, Challenges, Perspectives (Bonn: Bouvier), pp. 101-113.

Blažević, Zrinka, Suzana Coha (2007). 'Zrínyi Péter - a hősteremtés irodalmi modelljei és stratégiái', in Bene, Sándor, Gábor Hausner (eds), A Zrínyiek a magyar és a horvát históriában (Budapest: Zríny Kiadó), pp. 137-164.

Blumenberg, Hans (1979). Arbeit am Mythos (Frankfurt a.M.: Suhrkamp).

Bottici, Chiara (2007). A Philosophy of Political Myth (Cambridge: Cambridge University Press).

Castoriadis, Cornelius (1997). The Imaginary Institution of Society (Cambridge, Malden: Polity Press).

Flood, Christopher G. (2002). Political Myth. A Theoretical Introduction (New York, London: Routledge).

43 See http://nacija.hr/2018/o7/o7/svecenici-ratnici-za-hrvatsku-grudu-i-katolicku-vjeru/. 
Gligo,Vedran (1983). Govori protiv Turaka / Speeches against the Turks (Split: Književni krug).

Kovács, Kálmán (2015). 'Zríny. National Recycling(s) of a Hybrid Material (1566-200o)', in Blažević, Zrinka, Ivana Brković, Davor Dukić (eds), History as a Foreign Country. Historical Imagery in the South-Eastern Europe (Bonn: Bouvier), pp. 83-10o.

Marković, Tatjana (2014). 'Memorizing battle musically. The Siege of Szigetvár (1566) as an identity signifier'. http://lithes.unigraz.at/lithes/beitraege14_10/markovic_tatn jana_battle_musically_szigetvar.pdf [accessed 14.09.2017].

Paić, Ivo (1997). Sloboda i strah. Hermeneutika predziđa. Ogled o iskustvu svijesti hrvatskoga narodnog opstanka. [Freedom and Fear. Hermeneutics of Bulwark. An essay on the Consciousness of the Croatian National Survival] (Zagreb: Hrvatska sveučilišna naklada).

Rapacka, Joanna (2002). Leksikon hrvatskih tradicija [Lexicon of the Croatian Traditions] (Zagreb: Matica hrvatska).

Šanjek, Franjo (1993). Crkva i kršćanstvo u Hrvata [Church and Christianity among Croats] (Zagreb: Kršćanska sadašnjost).

Schatzki, Theodore R. (2001), 'Introduction. Practice theory', in Theodore R. Schatzki, Karin Knorr-Cetina, Eike von Savigny (eds), The Practice Turn in Contemporary Theory (London, New York: Routledge), pp. 10-22.

Stergar, Rok (2016). 'Illyrian Autochthonism and the Beginnings of South Slav Nationalisms in the West Balkans', in Antonino de Francesco (ed.), In Search of Pre-Classical Antiquity. Rediscovering Ancient Peoples in Mediterranean Europe (19th and 2oth c.) (Leiden, Boston: Brill), pp. 96-118.

Tudor, Henry (1972). Political Myth (Basingstoke: Macmillan)

Žanić, Ivo (1999), 'Die Poetik der Grenze. Fallbeispiel Kroatien', Lichtungen. Zeitschrift für Literatur, Kunst und Zeitkritik, vol. 20, no. 80, pp. 115-122.

Žanić, Ivo (2003). 'Simbolični identitet Hrvatske u trokutu raskrižje-predziđe-most / Symbolic Identity of Croatia in the Triangle Crossroads-Bulwark-Bridge', in Husnija Kamberović (ed.), Historijski mitovi na Balkanu [Historical Myths in the Balkans] (Sarajevo: Institut za istoriju), pp. 161-202. 
PART 4

Stereotyping in the Media 


\title{
Prime Time Nationalism
}

\author{
Patterns of Prejudice in TV Crime Fiction
}

Wulf Kansteiner

\begin{abstract}
Media research has shown time and again that the narrative worlds of prime time television have crafted powerful stereotypes of foreign recalcitrance and criminality. This contribution explores this dynamic through a case study of Germany's most popular prime time television crime fiction series Tatort or Scene of the Crime. Prime time television since the 199os increasingly presented sleek, emotionally manipulative stories of Turkish sexism, Polish slyness, Russian brutality, and Arabic terrorism, helping to establish them as widely shared social memories. It presents a narrative concoction all of its own, representing the liberal collective memory of the failure of multi-culturalism, and conveniently protecting the transnational liberal community from sharing the blame for the failed migration policies of the last decades. This contribution also explores an alternative: we need completely different media strategies to present images of people on the move and now living in our midst. Television prime time fiction and non-fiction should highlight the complexity and multi-causality of the migration experience, thus refraining from essentialising migrant profiles. Moreover, the media should reconstruct the challenges of migration from the moving people's point of view, thus providing powerful vectors of identification for people currently not on the move.
\end{abstract}

Generals always prepare for the most recent war and politicians always manage the most recent migration crisis - or what they and their voters remember as the most recent crisis. In this way collective memories of migration play a decisive role in policy decisions and may prevent societies from developing appropriate responses to resettlement processes.

That was the case in Europe in the year 2016. An estimated 2.2 million people arrived in the territory of the European Union during the so-called refugee crisis in 2015 and 2016 from Syria, Afghanistan, Kosovo, Eritrea and many other countries. ${ }^{1}$ That number represents merely $1.7 \%$ of the 130.9 million people

1 See Conor (2017).

(C) WULF KANSTEINER, 2021 | DOI:10.1163/9789004436107_011

This is an open access chapter distributed under the terms of the CC BY-NC-ND 4.0 license. 
forcefully displaced worldwide in those two years. ${ }^{2}$ Housing, feeding, and educating the two million hardly constitutes a serious financial or material challenge for the EU where, in 2016, 511 million people accumulated a combined GDP of $\$ 16,4$ trillion representing $21 \%$ of the global GDP. ${ }^{3}$ It would take a lot more refugees to overburden the resources of this area of extraordinary wealth. Moreover, in the long run, the refugees and their descendants are likely to become a demographic and financial asset rather than a burden to the EU. ${ }^{4}$ We are clearly not dealing with a material problem but a problem of culture, mentalities, ethics - and memory. Some problems of misperception are shortterm memory problems. The citizens of the EU remember the financial crisis of 2007 accompanied by economic contraction (for the first time since 1945), increased material inequality, and modest decreases in standards of living in some member countries. ${ }^{5}$ That experience might have negatively influenced member societies' willingness to welcome refugees into the EU. Other, more serious memory problems reflect long-term developments. Relevant segments of wealthy Northern European countries entertain decidedly negative views of the enduring consequences of post-WWII immigration events. They remember distinctly the labour migrations from Southern Europe in the 196os and 1970 and from Eastern Europe after 1990 and the influx of political asylum seekers since the 199os as having harmed their societies. ${ }^{6}$ Again, these negative assessments have little to no basis in fact. For most economists, the migrations in question have had positive rather than negative financial effects on host societies, and crime statistics reveal that only a few specific immigrant groups exhibit a clearly elevated propensity to commit crimes. ${ }^{7}$ It is important to insist on these facts but that hardly suffices. Collective memories are not based in fact; they are based in stories, images, and feelings. Faced with incontrovertible evidence to the contrary, populist politicians across Europe have insisted that they and their voters feel threatened by immigrants. Unfortunately, their feelings are difficult to change. Dealing with dysfunctional memories requires

2 See UnhCr (2016); UnHCR (2017).

See World Bank (2017).

See Kancs, Lecca (2017).

See Magalhaes (2015).

See Wilhelm (2017).

7 For a comprehensive assessment of the economic consequences of post World War II and post Cold War immigration in (West-) Germany see Spencer (1994); Klingst, Venohr (2017). 
effective memory analytics and memory interventions. We need new stories and feelings corresponding to the facts. ${ }^{8}$

The task of developing suitable memories and identities runs up against a veritable paradox. In principle, cultural memories and collective identities are fluid and malleable. Members of different collectives continuously reinvent themselves in symbolic and practical terms by differentiating individuals and groups that fall within their social contracts from those that fall outside of them or attain at best an ambivalent status. Plus, they constantly reshape the very nature of these contracts. For instance, scholars of nationalism have long abandoned the idea that cultural negotiations about the nation and its discontents unfold as stable processes and result in enduring notions of collective identity. They prefer to imagine nations as highly contingent cultural and psychological phenomena involving a wide range of heterogeneous and contradictory communications. ${ }^{9}$ At the same time, imagined communities and their invented traditions, including myths of national belonging, seem to have significant staying power even if they are blurry around the edges. Malleability and persistence are not mutually exclusive characteristics in the politics of memory and identity. The figure of the migrant and stories about migration play a decisive role in Western post-colonial societies' efforts to imagine themselves as sedentary, stable, advanced, civilised, and deservedly affluent. Unfortunately, refugees are subjected to these powerful fantasies of othering that come in many different flavors, from outright xenophobia to arrogant benevolence. ${ }^{10}$

The situation is analytically further complicated by the diversity of media arenas implicated in memory and identity negotiations. Nationally constituted, highly centralised, and transnationally networked old media landscapes like television co-mingle with social media environments with very different, multi-directional patterns of cultural communication and authorship and new forms of concentrated power over communication contents and structures (Hoskins 2018). Yet even if we focus on old media, which are our primary concern in this article, the task of cultural analysis remains complicated. There is

8 On the importance of debate and messaging in counteracting xenophobic political actors, see Lochocki (2018). In this context it is important to consider how European national and transnational government institutions and media companies narrate and remember Europe and the EU. See Spohn, Eder (2016) and especially Bondebjerg et al. (2017). It is also important to avoid the danger of dysfunctional banal Europeanisation; see Trenz (2016).

$9 \quad$ See Brubaker (1996).

10 See Bauman (2016); Nail (2015). 
ample material available to craft a compelling, robust story about the negative impact of TV content on migration memories. Media research, for example, has shown time and again that the narrative worlds of prime time television feature powerful negative stereotypes of foreign recalcitrance and criminality. ${ }^{11}$ As prime time became ever more violent and crime-obsessed in the 199os, hardly an evening went by in the big European TV markets without sleek, emotionally manipulative stories of Turkish sexism, Polish slyness, Russian brutality, and Arabic terrorism, followed by exceedingly repetitive late night talk shows echoing similar views and possibly establishing them as widely shared social memories. ${ }^{12}$ The story can be further elaborated by connecting key elements of popular culture to right wing radicalisation. Effectively enhanced by racist propaganda, compacted collective symbols of alterity may have found an eager audience among the voters of right-wing populist parties who tend to be "male, young(ish), of moderate educational achievement and concerned about immigrants and immigration".13 This stream of repetitive media images and its social base might be the collective memory one is up against in an attempt to build a more inclusive society.

At the same time, the story is hardly that simple. First of all, TV content about foreigners and migration has often not been dominated by negative stereotyping. To name just one example, after $9 / 11$ US commercial television networks featured a great deal of Arab bashing but also a similarly sustained series of programs about good Muslims living the American dream while victimised by US xenophobia. ${ }^{14}$ All of that raises the interesting question of how audiences react to the co-presence of positive and negative stereotyping and, more specifically, of how viewers respond to ironic representations of ethnic and racial prejudice designed to counteract bigotry. ${ }^{15}$ While it makes sense to assume that centralised cultural distribution systems like television offer important information about popular registers of collective identity, one should keep in mind that the carefully designed fantasies of national and ethnic belonging distributed via satellite and cable differ in form and content from the ways in which citizens think and feel about the burden and privileges of group affiliation. After all, even after decades of TV research, we have

\footnotetext{
11 On stereotyping of muslims after 9/11, see Morey, Yaqin (2011); Mertens, de Smaele (2016).

12 See Kretzschmar (2002); Trebbe (2009); Goebel (2017).

13 Arzheimer (2017), p. 287. The storyline is consistent with hegemonic interpretations of right-wing electoral success across Europe, see for instance the analysis of the 2017 federal election in Germany in Spiegel online in Kwasnieski (2017).

14 See Asultany (2012).

15 See Keding, Struppert (2009).
} 
frustratingly little insight into $\mathrm{TV}$ reception processes, although we know for instance that identical media texts may have very different effects in different settings. ${ }^{16}$ Similar questions and lacunae arise when one directs one's analytical gaze at the assumed users of anti-migration memories, for example, the supporters of right wing political parties in Europe. The voter profiles generated by electoral sociologists only reflect the relative affinity between social data and voting decisions and even these profiles might already have been subject to significant mainstreaming. ${ }^{17}$ Moreover and more importantly, relative statements about voting propensities obviously provide no basis for connecting problematic media coverage to specific political phenomenon, for example, by linking the electoral success of the right wing political parties to prejudicial TV programs possibly consumed by their voters. ${ }^{18}$

I apply two conceptual perspectives to analyse the prehistory of the media event refugee crisis. First, a structuralist point of view well suited to highlight the problematic dynamics of post-colonial othering pervasive in Europe's mass media. This traditional approach captures layers and continuities of post-WWII and post-colonial xenophobia and racism, demonstrating that the cultural arena has never been a level playing field for new arrivals. Refugees never had a real chance of inserting themselves successfully into a cultural terrain systematically stacked against them. In addition, I apply a memory studies vantage point that paints a more complicated picture. As the collectively constructed crisis unfolded, two different memory regimes have struggled for supremacy. On the one hand, there were conventionally antagonistically structured memories confirming a simplistic us vs. them divide easily captured by structural analysis. These nationalistic memories contributed to the rise of the radical right across Europe - although it is remarkable how successfully the professed nationalists crafted transnational political and memory networks across the continent. On the other hand, some segments of Europe's societies deployed top-down cosmopolitan memories to frame the crisis within a humanitarian narrative trajectory tapping into human rights and Holocaust memories. Both approaches were successful in that they mobilised political actions, although hardly in any integrated fashion or with comparable degrees of sustainability. The countries following traditional antagonistic storylines far outnumbered the countries willing to give cosmopolitanism a try, as for example Sweden and Germany did. Moreover, in the end, neither memory regime succeeded in providing compelling long-term perspectives and policy

\footnotetext{
16 Lind (2010); Gorton (2009).

17 See Rooduijn (2016).

18 See Arzheimer (2018); Ellinas (2018).
} 
solutions. The antagonistic narrative collides with the simple fact that Europe is a site of irreversible, large-scale migration whereas the cosmopolitan utopia fails to provide practical guidelines for generous yet also clearly circumscribed immigration policies. As we will see, Europe needs a third memory culture that can extend welcome to many more refugees and help with the difficult task of developing ethics of material and legal equality.

With these notes of caution and conceptual contextualisation we now turn to a layer of media history, and arguably also a powerful source of collective memories of migration that predates the 'refugee crisis' by over a decade and thus represents exactly the kind of media fare the witnesses, bystanders, and protagonists of the 'migration crisis' of 2015/16 have consumed over the course of the last decades. Our case study concerns the 2003-2004 season of the German TV series Scene of the Crime (Tatort), which is Germany's Sunday evening prime time flagship program and whose 2003-2004 season featured 34 broadcasts and a number of in-depth engagements with the topic of migration.

\section{Whose Jungle Is It Anyway?}

On October 26th, 2003, 6.5 million German TV viewers watched Berlin detectives Ritter and Stark solve the murder of an illegal immigrant from Nigeria whose corpse had been dumped at the airport. Jungle Brothers (Dschungelbrüder), as the program is provocatively entitled, does not spare any didactic efforts but suffers from a number of shortcomings.

Right at the start, Ritter delivers an impressive yet also improbable impromptu lecture about the pieces of West African jewellery found on the dead man. Further along in the investigation, the Berlin cops dutifully, albeit somewhat laconically, inform the viewers about poverty and corruption in a long list of West African countries, criticize the exploitation of illegal immigrants as a source of cheap labor, and acknowledge that the majority of African immigrants, including people who have lived in Germany for most of their lives, have no chance to attain refugee status. In passing, Ritter and Stark also perfunctorily deplore racism in Germany. But the program does not show vivid instances of racism with the exception of the occasional use of the word darky ('Bimbo') by one of the shadier characters of the story as he addresses his illegal immigrant workers. The program offers theoretical information about xenophobia but does not render it tangible in any meaningful way.

Jungle Brothers has other weaknesses. Perhaps in an attempt at realism in the depiction of police-immigrant relations, the creators of the film have the detectives treat black witnesses and suspects with considerable arrogance and 
distrust. Thus the very carriers of PC-consciousness in the story, whom regular $\mathrm{TV}$ viewers know as compassionate figures, are reinforcing the symbolic divide between Germans and others - notwithstanding the fact that some of the others are German citizens..$^{19}$ Moreover, in order to satisfy the requirements of prime time and in an effort to illustrate that immigrants are human beings just like the viewers in front of the screen, the director has all black actors deliver their lines in flawless German. Thus characters in the story with non-German backgrounds, including recent arrivals, display stunning linguistic capabilities that simply do not reflect everyday life in multi-lingual German cities. ${ }^{20}$ This feat of foreign language acquisition bestows a cyborgian quality on some immigrant figures, inadvertently turning them into a specially marked group of people within the narrative universe on the screen.

However, the most decisive flaw of Jungle Brothers concerns the depiction of the crime itself. In the first scene of the film, the refugee Koffi is murdered by the black father of his girlfriend. The father is a successful business tycoon who immigrated to Germany from Cameroon in the late 1960s. He now owns commercial property all over Berlin and moves in the highest circles of the city, where he is almost but not completely accepted as an equal by his urban jungle brothers. The father finds Koffi unacceptable as a son-in-law, offers him money if he promises to leave his daughter alone, and accidentally kills him in the fight that ensues after Koffi rejects the bribe. Thus, the first-generation black immigrant turns out to be the biggest bigot in the world of Jungle Brothers.

The brief look at the plot structure of Jungle Brothers already hints at a fundamental dilemma that lurks at the intersection of the genre crime show and the topic of migration. The director and screenwriter of Jungle Brothers, Lars Becker, certainly had the best of intentions. He himself is married to a woman of colour and planned to make viewers aware of the problems immigrants face in German society. ${ }^{21}$ But within in the current genre setting, a crime show about migration requires migrants in the roles of victims and/or perpetrators - in addition to a set of more or less heroic non-migrant detectives representing the host society. In this narrative terrain plot options are clearly limited and the creative staff will have to engage with migrant stereotypes in one way or another. That raises tough questions about how much (violent) racism one can responsibly depict on the screen. The problems are exacerbated by Becker's script. How does one turn foreigner-on-foreigner violence into a self-reflexive study of German racism, especially if the viewers learn the identity of the murderer right

\footnotetext{
19 See Wallnöfer (2003).

20 See Bonner Generalanzeiger (2003).

21 See Gehrmann (2003).
} 
after the opening credits? Finally, Becker faced even more of an uphill battle because Jungle Brothers is part of the prestigious series Scene of the Crime that restricted his aesthetic options. The German detective team Ritter and Stark were established prime time figures combining cool with conscience and leaving little space for alternative heroes. Under these circumstances it is not surprising that Becker did not succeed in subverting powerful prejudices. The film follows the conventional rules of the genre and validates the superior sceptical gaze of the enlightened German law-enforcement officers who bring to light the shady dealings and psychological hang-ups of ethnic minorities living in the German capital. Jungle Brothers thus sends a devastating message about German society that probably only partly reflect Becker's political intentions: the integration of black immigrants in Germany is doomed to fail even under the best of circumstances. The immigrants might be economically successful and seemingly well-adjusted but the combination of traditional tribal prejudice, immigrant insecurities, and entrenched German racism may sooner or later turn them into dangerous xenophobes, especially if they successfully emulate German values. ${ }^{22}$ One can easily imagine that these kinds of stories, reproduced in the media on a daily basis, have dire effects. When they intersect with a fear of migration on the part of viewers and the arrival of real migrants, especially migrants perceived as poor and dark-skinned, the stories likely contribute to the collective construction of a 'refugee crisis', especially if the perceived risks and fears of migration are not held in check by countervailing memories.

\section{A Memorial to Whiteness}

As an installment of the series Scene of the Crime (Tatort), Jungle Brothers is part of a venerable German media tradition. Scene of the Crime has been produced for over four decades and, by March 2021, had a record of 1161 original programs, not to mention tens of thousands or reruns. ${ }^{23}$ It might very well be the longest-running prime-time fiction program in the world. Yet while Tatort may rightfully lay claim to global significance in statistical terms and has been broadcast in over 50 countries, it remains a thoroughly German phenomenon that thrives in Germany's peculiar cultural and media landscape. ${ }^{24}$ The 5o-year history of Scene of the Crime comprises over seventy-five different investigative

\footnotetext{
22 See Wallnöfer (2003); Bohn (2003a).

23 See Tatort-Fundus (2018a); Brück, Guder, Viehoff, Wehn (2003), pp. 159f.; Hickethier (1998), p. 237; tatort-fans.de (2021).

24 See Hamburger Abendblatt (2016).
} 
teams located in cities all across the Federal Republic. Each team represents a different region with its landmarks and cultural and linguistic peculiarities. Scene of the Crime renders Heimat both regionally specific and nationally recognizable. ${ }^{25}$ In this vein, Scene of the Crime has been a cultural vehicle of national integration in West, East, and unified Germany. Consequently, Scene of the Crime has a large, dedicated, multi-generational cult following that turns the broadcast of new installments into media events. ${ }^{26}$ These audiences expect entertainment and suspense but also social commentary. As a result, Scene of the Crime provides an important platform for political self-reflection with each investigation carefully calibrated to navigate, manipulate, and occasionally challenge the perceived limits of popular taste. In this way, Scene of the Crime presents interesting interpretations of the social and political status quo in Germany. ${ }^{27}$ Every important political issue has been addressed over the years, including East German and West German relations and unification, neo-Nazis and the Nazi past, feminism, social inequality, unemployment, abortion, xenophobia, AIDS, religious sects, euthanasia, prostitution, migration, child labor and abuse, globalisation, and genocide. The people behind Scene of the Crime, including many first-rate directors, screenwriters, and actors, are very aware of the fact that they are managing a national label that offers them extraordinary career opportunities. ${ }^{28}$

There are other developments that have turned Scene of the Crime and similar programs into central sites of cultural memory. Germany's media landscape changed decisively in the early 199os when commercial stations, which had first been licensed in West Germany in 1984, started to match their public service rivals in program diversity and audience appeal. The ensuing competition transformed television fare in Germany, especially during prime time, killing off a number of venerable public service series and formats. ${ }^{29}$ But crime dramas in general and Scene of the Crime in particular have thrived in the new TV environment. Between the mid-1980s and the mid-199os, airtime for primetime cop shows increased more than fivefold. ${ }^{30}$ Scene of the Crime showings jumped from twelve broadcasts in 1989 to over thirty per year since 2002. There

25 See Bollhöfer (2007); Mously (2007).

26 Some Crime Scene investigators have become celebrities - most notably Götz George aka Schimanski - and the introduction of new detectives is vigorously discussed in national tabloids and TV guides; on the Schimanski phenomenon see Harzenetter (1996).

27 See Hißnauer, Scherer, Stockinger (2014).

28 Tatort was for instance the springboard for Wolfgang Petersen's career. He directed a number of episodes in the 1970s, including the famous Reifezeugnis of 1977; see Tatort-Fundus (2018b).

29 See Krüger (2002).

30 Wehn (2002), p. 7f., 194. 
is a simple explanation for this development. Crime dramas constitute one of the few reliable recipes for successful ratings in a crowded field of TV content providers. Scene of the Crime is again a case in point. The series no longer reaches audience shares of over 5 o per cent, which was not unusual during the era of the public service monopoly of ARD and ZDF. But with an average of 8 million viewers and 23 per cent market shares per prime time broadcast, Scene of the Crime has generally remained the most popular program of the primetime line-up on Sunday evening. ${ }^{31}$

At the precise moment when crime shows in general and Scene of the Crime in particular filled ever more airtime, unified Germany experienced increased immigration and a wave of right-wing violence against foreigners in the early 199 os and, partly in response to these events, drastically curbed non-EU immigration by negotiating a system of EU controls. ${ }^{32}$ Yet despite anti-immigration legislation prompted by popular xenophobic resentment, Germany relies on immigrant labor for its economic wellbeing and by 2020 the percentage of foreign citizens and people of so-called non-German background living in Germany had risen to $13,9 \%$ and $26 \%$ respectively. ${ }^{33}$ In this heterogeneous group of approximately 21 million, three million people of Turkish descent represent the largest subsection and, until the events of 2015/16, were considered among the least well-integrated foreigners in Germany. As a result of recent developments, hierarchies of belonging are somewhat in flux in the Federal Republic although there have always been various cultural constructs of migrating Muslims that served as the symbolic antipodes of the constructs 'German' and 'European' in post-Cold War Germany. ${ }^{34}$

German television has played an important role in the remapping of collective national-ethnic identities after the fall of the Berlin Wall. A study from 2007 revealed that 81 percent of the coverage about Muslims on the public stations ARD and ZDF presented Islam in an overwhelmingly negative light. ${ }^{35}$ That figure neatly corresponds to the 83 percent of the German population who held decidedly unfavorable opinions about Islam at that point in time. ${ }^{36}$ Both trends have continued unabated in the last ten years. ${ }^{37}$ However, while these statistics seem to speak a clear language, German television's encounter

\footnotetext{
$31 \quad$ See Tatort-Fundus (2018a).

32 See Geddes, Scholten (2016), p. 95.

33 See Statistisches Bundesamt (2021).

34 See Dietrich, Frindte (2017), p. 112.

35 See Hafez, Richter (2007).

36 See Noelle, Petersen (2006).

37 See Focus-Online (2017); Hafez (2017).
} 
with Islam has been quite complex. TV executives have tried to deal with the problem of racial prejudice by offering viewers a number of critically acclaimed programs calling into question ethnic stereotypes, especially regarding Turks. The programs include the docu-soap Die Özdags (WD R 20078) and the award-winning sitcom Alle lieben Jimmy (RTL 2005-7). ${ }^{38}$ Scene of the Crime itself may serve as another, on first sight positive example. Between 1991 and 2003, partly in response to the wave of xenophobic violence mentioned above, the topic of migration has been addressed, in greater or lesser detail, in almost 20 percent of all Scene of the Crime episodes. ${ }^{39}$ Thus German public television has tried to step up to the plate and media scholars have generally acknowledged these efforts, ${ }^{40}$ although, as we have seen above, engaging with the topic is not synonymous with effectively counteracting xenophobic sentiments. Consider in this context the first (!) German-Turkish detective, Cenk Batu, whom ARD Scene of the Crime executives sent on crime-fighting missions in the gritty urban setting of Hamburg from 2008 to 2012. ${ }^{41}$ Batu retired after only 6 episodes and the figure assumed a very ambivalent profile right from the start. Batu was the only undercover detective in Scene of the Crime. In that role he assumed the personae of Turkish criminals and Islamist terrorists, and, on his last case, went on a vigilante rampage. Consequently, especially on a visual level, Batu often performed rather deconstructed hegemonic cultural patterns of racial prejudice and Muslim migratory threats. ${ }^{42}$ Over half a century, Scene of the Crime has remained a thoroughly racist narrative universe in which white detectives chase white, brown, and black criminals. ${ }^{43}$ Things are only changing slowly. The arrival of a small cohort of Turkish-German investigators represents the most important innovation in this regard. Since 2013 the Hamburg crime team includes the Turkish-German detective Yalcin Gümer who, however, only provides support services to his macho boss Nick Tschiller played by famous, controversial, and equally macho German actor Till Schweiger. Since 2012 and 2017 respectively, the Dortmund and the Kiel team feature young female Turkish-German detectives who embrace (Kiel) or ignore (Dortmund) their non-German heritage. Finally, since 2019,

\footnotetext{
$38 \quad$ See Domaratius (2009).

39 See Ortner (2007), p. 85; Buhl (2014), p. 76.

40 See Wellgraf (2008); Ortner (2007); Thiele (2005).

41 See Tatort-Fundus (2018c).

42 See Spielberger (2012). Similar problems arise with regard to the longest serving immigrant Scene-of-the-Crime detective, Munich's Ivo Batic with Yugoslavian roots, who also suffers from an excess of Mediterranean temper; see Thiele (2005), p. 197.

See the gallery of white and predominantly male detectives at Tatort-Fundus (2018d).
} 
the Ugandan-German actress Florence Kasumba plays the Ugandan-German investigator Anais Schmitz who, in her first appearance on the screen, engages in an activity that breaks with Scene of the Crime etiquette because she physically attacks her female fellow investigator. As of 2021, roughly 10 percent of active investigators are no longer representative of the white, ethnic German mold. That is progress. ${ }^{44}$

Nevertheless, TV networks and critics have simply not paid enough attention to the problematic narrative and aesthetic strategies with which crime shows influence perceptions of foreigners and processes of social integration. Cop shows like Scene of the Crime focus on deviancy and symbolically adjudicate social behavior and in this fashion shape the everyday performance of collective memory. According to Jack Katz, crime shows are so successful and such a great source of historical analysis because they appeal to the audience's strongest-felt positive and negative emotions. By watching crimes unfold on the screen, viewers collectively partake in a daily moral workout that reflects their passionate desire for safety and raises fundamental questions about the reproduction of social order. ${ }^{45}$ Thus popular television offers intriguing interpretations of fundamental fears and hopes, especially with regard to the cultural construction of others. After all, few topics are more emotionally and politically engaging than the question of who does and who does not belong to one's society and how people aspiring to membership should conduct themselves. In this sense, the communications surrounding crime shows about migration touch upon the very essence of human self-consciousness. ${ }^{46}$ Put differently, the serial production of xenophobically structured programs is not just a likely risk in an innovation adverse genre setting like prime time crime, but should actually be recognized as one of the genre's key functions at a time when positive collective self-images in the West appear to be inextricably linked to negative constructions of foreignness and migration. Needless to say, these imagined worlds come with a hefty price tag, first and foremost for migrants, but also for host societies.

\section{3} Orientalising Crime

Lars Becker was not the only creative mind at ARD who used Scene of the Crime in the 2003-4 season to address the topic of migration. In August 2003

\footnotetext{
44 See tatort-fans.de (2020).

45 See Katz (1987).

46 See Rudolph (2007), pp. 49-51.
} 
screenwriter Harald Göckeritz and director Martin Weinhart tackled a particularly thorny issue when they explored the interdependence between illegal migration and the international black market for organ transplants. Their film focuses on the plight of migrants who have been smuggled into Germany under false pretences and are now pressured to serve as organ donors. The refugees have found temporary shelter in a dilapidated public-housing development in Ludwigshafen, where they are eyed with considerable suspicion by the authorities and left unprotected against assaults from an international organ transplant mafia. Detectives Odenthal and Kopper take a close look at the migrants when a refugee headed for the housing development is found dead in a nearby gravel pit. The film quickly focuses on the anguish of a 12-year old Kurdish girl who survived persecution in Turkey and Iraq and now has to fend for herself because her brother, her only remaining relative, has not returned from a mission as an organ donor in Ukraine. ${ }^{47}$

Leyla, broadcast on 31 August 2003 to an audience of 6.9 million viewers, has self-critical potential. Göckeritz and Weinhart forgo any simple happy end. As the detectives are successfully wrapping up their investigation, the camera focuses on another helpless migrant on his way to yet another risky surgery abroad..$^{48}$ In other compelling moments of the film, viewers get a palpable sense of the despair that makes parents of chronically sick children participate in a perfidious system of exchange in which the desperate exploit the poor. Last but not least, the script occasionally assumes the perspective of the refugees, especially by offering a detailed account of the growing panic of 12-yearold Leyla. But the figure of the girl also proves Göckeritz' and Weinhart's downfall. They string together scene after scene of Leyla mournfully inspecting the empty mailbox, placing yet another unanswered call from a public phone booth, or patiently waiting by the window, illuminated by candlelight, with vaguely Middle Eastern music playing in background. The stereotypical spectacle of childlike innocence, flavored with a dash of exoticism, robs the character of complexity and agency, rendering Leyla and her peers defenseless against organ smugglers as well as self-indulgent projections of munificence on the part of the viewers. Leyla is a picture-perfect example of orientalism. ${ }^{49}$

Moreover, the implicit audience constructed in the televisual universe of the film, which is treated to the spectacle of exotic innocence and seemingly invited to identify with Leyla, is defined along narrow ethnic and linguistic

\footnotetext{
47 See Frohn (2003).

48 See Bohn (2003b).

49 A similar process of balkanisation occurs in Scene-of-the-Crime installments dealing with crimes linked to the wars in the former Yugoslavia; see Gladis (2016).
} 
lines that undercut empathetic engagement with the plight of the refugees. The team of investigators and medical support staff, i.e. the heroes of the film, only consists of white, middle-class German native speakers. ${ }^{50}$ This homogenous group of well-adjusted individuals enlightens the audience about a thriving international business of illegal organ transplants in China, Russia, Ukraine, India, Brazil, and the Czech Republic. Through their profile and their actions they draw a line in the sand, somewhere east of Berlin. After all, as Odenthal puts it succinctly on one occasion: "This is Germany." Consequently, all perpetrators are clearly marked as outsiders. The leader of the smuggling enterprise is a stereotypically stoic Russian who kills people without the slightest hesitation; the physician examining the refugees is an ethnic German who grew up in Siberia and still mutters Russian under her breath; the thug who is sent after the victims speaks with the thickest of Bavarian accents, marking him with a powerful sign of alterity according to the cultural codes of the German media.

There are two signs of ambivalence in the neat narrative world of Leyla. The first unpersuasive marker of hybridity is Leyla herself. After only two months in Germany she speaks excellent German. The second character caught between the lines is the social worker Marler, portrayed masterfully by veteran actor and Tatort-regular Jürgen Tarrach. Marler frequently helps the migrants with their everyday problems, but also advises them to accept the deals offered by the smugglers. When confronted by Odenthal and Kopper with the consequences of his corrupt dealings, Marler deeply regrets his actions and contemplates suicide. But he remains the only wrinkle in the tidy national universe of Leyla. ${ }^{51}$ Overall, the film depicts crimes committed by foreigners against foreigners with the former complaining about German laws that complicate their business and about German welfare payments that drive up the prices for organ 'donations'. The viewers can hardly avoid the conclusion that more rules and more aggressive policing are needed in order to force the thugs and their victims to conduct their unappetising business elsewhere - without the benefit of German infrastructure and taxpayer support.

\footnotetext{
50 The picture is complicated by the fact that Tatort aficionados know Kopper to be of Italian-German descent (although that does not play a role in Leyla). In addition, the actress Ulrike Folkerts, who plays Odenthal, is widely known as one of a few openly gay German actresses.

See Bohn (2003b).
} 
In addressing the problems of multiculturalism in Western societies, the makers of Scene of the Crime are clearly handicapped. The crime-drama genre provides only limited opportunities to highlight the positive side of migration. A murder mystery needs a corpse, a murderer, and a compelling motive; a clash of cultures is an excellent plot structure that offers all of the above. In the 2003-2004 season that was clearly the case. Scene of the Crime addressed questions of migration and integration on a routine basis and each time the gripping storylines made a powerful case for cultural homogeneity. In fact, the message could not have been stated more bluntly: the West is better off if it does not get involved in the shady dealings, tribal tensions, and reactionary values of migrant communities. None of the regretful deaths of migrants would have occurred - or at least would not have occurred on Western soil - if the foreigners had simply stayed put. Leyla und Jungle Brothers convey attractive and highly antagonistic memories of migration.

A closer look at the cross-section of crime dramas focusing on migrants and foreigners has revealed rather disappointing results. In each case, the murder is committed by a migrant/foreigner and national identity and mainstream values are affirmed in simplistic ways that offer few opportunities for self-reflection. The programs are obviously not dealing well with the multicultural challenges of the twenty-first century. Under the circumstances it might be helpful to broaden the scope of analysis and gain some comparative perspective. The topic of contemporary migrations seems to overtax the didactic skills and political imagination of the creative staff in charge of crime-drama production. But perhaps screenwriters, directors, and TV executives are more astute in their representation of established and well-integrated minority communities like German Jewry. After all, Western culture has had a lot of opportunities to think about Jewish-Gentile relations and after 1945 these reflections have often taken a decidedly self-critical turn, especially in Germany. Moreover, in particular since the 1970s, television has played a particularly important and often constructive role in Holocaust education. ${ }^{52}$

On December 7 th, 2003, over 7 million viewers watched an aesthetically and politically ambitious episode of Scene of the Crime that painted a critical and discouraging picture of Jewish-Gentile relations in contemporary Germany. The events in The Shochet (Der Schächter) are set into motion by a mentally

See Shandler (1999); Kansteiner (2006); Kansteiner (2011). 
handicapped young man who, in a state of panic, cuts the throat of a homeless boy after having been threatened by the boy's attack dog. The brother of the perpetrator covers up the crime by planting corpse and murder weapon in the house of a shochet, who is subsequently vilified in the press and relentlessly pursued by an antisemitic district attorney. The actual crime and the pursuit of the murderer are not center stage in the program. Instead, the veteran screenwriter Fred Breinersdorfer offers a morality play about persistent antisemitic prejudice in the German provinces. ${ }^{53}$ The convoluted storyline, lacking suspense and veracity but overflowing with didactic ambition, is delivered in carefully constructed, increasingly more disturbing images and combined with an evocative, highly symbolic soundtrack. The program begins with idyllic scenes of the shochet, the lead detective, and the handicapped man playing boule along the banks of Lake Constance. As the case unfolds, the viewers witness the repeated, aggressive interrogation of the shochet staged with Brechtian techniques in sterile early twentieth-century institutional architecture. Apart from the interrogations, the district attorney calmly and seemingly rationally invokes all kinds of antisemitic stereotypes, from greed to blood sacrifice, to bolster his case. Shortly before the climax of the story, director Jobst Oetzmann shifts aesthetic gears and replaces the distance-inducing alienation techniques with subjective camera angles and unsteady camera movements designed to make the viewers sense the rising panic that the shochet, a survivor of Treblinka, experiences as he is once more victimised by German officials. ${ }^{54}$

The director of The Shochet develops a lot of cinematic ambition in an effort to induce empathy with the accused and instill properly anti-antisemitic values in his audience. But the program also contains a number of contradictory plot elements that insert an interesting level of narrative ambivalence and raise doubts about the philosemitic credentials of the lead detective and possibly the program as a whole. ${ }^{55} \mathrm{On}$ the one hand, the proceedings against the shochet are always conducted according to the rule of law, despite the crude antisemitic slogans that the prosecutor delivers outside the courtroom. The lead detective and an impartial judge make sure that justice is done. So the fears of the shochet, especially his growing suspicion of his detective friend, appear increasingly paranoid. On the other hand, a strangely passive lead detective does not seem to resist the antisemitic onslaught as aggressively as one might expect. Moreover and most importantly, viewers are told several times over the course of the film that the shochet spent his childhood in Konstanz, became

53 See Sauerwein (2003).

54 See Heinen (2003).

55 See Gangloff (2003); Anders (2003). 
a well-respected member of the Strasbourg Jewish community after 1945, and only returned to Konstanz on a part-time basis in recent years because he had inherited a beautiful and valuable house on the shore of Lake Constance. Now that he is harassed by law enforcement, the shochet plans his illegal departure from Konstanz and permanent escape to France.

Thus Breinersdorfer invokes antisemitic stereotypes of wandering Jews with shifting loyalties in pursuit of material gain and illustrates how difficult it is to find one's way out of the maze of philo- and antisemitic traditions that are a part of contemporary German culture. In this way, he and Oetzmann open up the film for a wide range of possible readings. Some viewers might have felt encouraged to reflect about their own latent fears of ethnic-cultural alterity and moments of disturbing transference (as Breinersdorfer and Oetzmann probably hoped they would). Others might have come to the conclusion that disengagement seems like the best solution and that the local German-Jewish symbiosis should be ended before worse things happen. In fact, until the very last seconds of the show, the plot and the camerawork squarely point towards segregation and the benefits of ethnic homogeneity. ${ }^{56}$ Finally and most disturbingly, the ambivalences and performances of antisemitism might have prompted some members of the audience to revel quietly in antisemitic prejudice. ${ }^{57}$

Crime shows with Jewish and Holocaust subject matter convey stern warnings about the need for political vigilance and ethnic tolerance, in the case of The Shochet cast into an ambitiously complex and self-reflexive TV story. Everybody involved in television, from producers to consumers, seems to recognize the Holocaust as a site of humility and earnest historical exploration. It is very possible, however, that decades of Holocaust memory work have simply resulted in the creation of narrowly circumscribed cultural ghettoes of cosmopolitan self-reflexivity. The habitual, self-critical impetus noticeable in TV programs with Jewish subject matter does not seem to be transferred to televisual engagements with other contemporary problems of memory whose solutions depend on a similar combination of self-reflexive resolve and innovative zeal. In fact, from a structuralist perspective, the situation appears to be even more sinister. What if the belated, proudly performed critical engagements with the legacy of Nazism play an important role in the thoughtless reproduction of

\footnotetext{
$56 \quad$ See Winter (2015).

57 There are good reasons to assume that a significant share of the audience might have indeed favored this last reading. In December 2003, a month before the broadcast of Der Schächter, a high-profile political scandal broke in Germany that revealed the persistent anti-Semitic sentiments of conservative politicians and their voters. See Herzinger (2003); Kansteiner (2006), pp. 308-12.
} 
contemporary patterns of anti-migration prejudice? Does Holocaust memory facilitate contemporary racism and nationalism? Or have the rituals of German Holocaust culture effectively curbed xenophobia, for instance by helping to create the welcoming culture for refugees that briefly flourished in Germany in 2015-16? Is chancellor Merkel's famous sentence "We'll manage that" ("Wir schaffen das") a concrete application of the ethical demands of Holocaust memory as suggested by the Holocaust survivor Ruth Klüger in her speech to the German parliament in January 2016?58 Maybe 2015 represents a brief, unusual moment in which collective memories of past mass crimes intersected with resettlement processes for the benefit of refugees? Either way, the brief look at the symbolic-ideological dynamics of the media world of primetime crime highlights the difficulties involved in any attempts to brush the genre against the grain and engage in a truly self-reflexive communication with the audience.

\section{$5 \quad$ Levelling the Playing Field}

The culture of prejudice, which is a constituent element of primetime TV, is not representative of all mainstream visual culture. German film and TV culture, for instance, features a long and very successful tradition of anti-xenophobic media stories exemplified by such different media texts as the documentaries of Hans Dieter Grabe from the 1980 s, ${ }^{59}$ or the successful feature films of Fatih Akin produced since $1998 .{ }^{60}$ Even the annals of Scene of the Crime include an exemplary 1998 episode called Trapped (In der Falle), which effectively criticizes the campaign of structural violence waged by the German state against Turkish immigrants. ${ }^{61}$ But, at the same time, the low profile, everyday cultural reproduction of structural racism and nationalism continues unabated. ${ }^{62}$

The above findings offer an opportunity to develop a systematic, structural critique of the crime drama with regard to its construction of alterity. The overwhelming presence and popularity of cop shows give rise to the suspicion that law and order programs have emerged as one of the primary cultural sites

\footnotetext{
$5^{8} \quad$ See Galaktionow (2016).

59 See Hißnauer (2009).

6o See Mackuth (2007); Rings (2016).

61 See Ortner (2007), pp. 139-16o.

62 See for instance the two-part, high-profile 2020 sequel of Tatort entitled "In the family" (In der Familie) marking the 5oth anniversary of the first Tatort broadcast, ARD 29.11.2020 and 06.12.2020. The film presents a picture-perfect xenophobic story featuring an Italian immigrant forced by the Mafia to kill his German wife.
} 
of collective and national identity in a post-Cold-War era in which the media have sworn off the use of overtly nationalistic and xenophobic strategies of representation. In the absence of the kind of clear cut visual and narrative codes circulating at the height of colonialism, fascism, and communism, television producers and their audiences in the West have settled on new master scripts to regain stable Western, European, and national bearings. In this fashion, the crime drama has become a powerful contemporary master symbol whose language, metaphors, and narrative designs are well suited for boosting morale in the respective in-group at the expense of various symbolic others along shifting lines of demarcation. The crime drama has emerged as a site of troublesome historical disinformation and self-fulfilling analytical prophecies. In the course of constantly rewriting and symbolically adjudicating the history of ethnic relations in the West and beyond, popular TV shows provide viewers with powerful tools for the interpretation of contemporary debates about migration, which make them all the more likely to adopt nationalistic and racist points of view. All these factors explain why producing a truly enlightened crime drama about migration seems to require nothing short of subverting the essence of a genre thriving on passive-aggressive politics of exclusion and stereotyping.

In the current cultural context, educational campaigns engaging with the topic of migration face a number of obstacles. The fight against prejudice often seeks to criticize ethnic stereotypes by presenting them in an exaggerated form, the political effects of which are difficult to gauge (Wellgraf 2008, 39). Ironically, the exaggerations are linked to collectively constructed standards of veracity. Viewers expect from television a realistic engagement with contemporary issues, including realistic representations of the kinds of problems they assume exist as a result of migration. But the producers' and viewers' perceptions of reality, which play an important role in successful communication via television, exist largely independent of the type of realism constructed in crime statistics, scholarly papers or other scientific data. In fact, prime time fiction and non-fiction create their own standards of truth. ${ }^{63}$ The exploration of minority communities from the vantage point of law enforcement for instance creates a seemingly compelling causal link between migration and crime and in that respect systematically misrepresents the basic characteristics of actual crimes as well as the efficacy of law enforcement agencies. ${ }^{64}$ Needless to say, the actual conduct of migrants is less important for their perception by host communities than the characteristics attributed to migrants in the media.

\footnotetext{
63 See Enli (2015).

64 See Ortner (2007), p. 176.
} 
In the light of high stakes involved in this media feedback loop, it is useful to recall guidelines for the representation of migrants on $\mathrm{TV}$ developed by the media scholar Christina Ortner. Empathy with members of minority groups is more easily induced by TV stories that feature migrants as main protagonists, present events from the migrants' point of view, and depict the private and professional complexities of their lives. All too often, even in shows designed to criticize xenophobic violence, camera and script linger on the non-migrant perspective in an attempt to understand and condemn anti-migrant sentiments. In addition, the cause of cross-ethnic peace and understanding is more successfully championed by TV programs that emphasize the heterogeneity of in-groups and out-groups and delineate generous criteria for membership in in-groups. ${ }^{65}$

An implementation of these guidelines might indeed result in politically more desirable television programming although the shows would transgress the limits of the genre and no longer meet the expectations of many audience members who take pleasure in watching upstanding white police officers solving the problems of a globalised world. ${ }^{66}$ Ortner's well-intended cosmopolitical guidelines thus inadvertently highlight the structural dilemma inherent in televisual communication and the need for more radical cultural change. Any coverage of a politically sensitive and complex topic like migration, especially in prime time, will nolens volens convey the kind of messages that Roland Barthes has defined as myth, i.e. fairly simplistically structured, easily understood, and semantically over-determined arguments concerning the dangers or advantages of diversity and migration that are difficult to replace by other, ethically, politically, and economically more suitable myths. ${ }^{67}$ Reforming myths about migration amounts to an uphill battle because the cultural terrain in which these negotiations take place does not constitute a level playing field. As Jürgen Link has shown, most collective symbols and metaphors, which have traditionally been used in discussions about difference and migration - and that are thus almost indispensable for effective mass-media communication about the topic - carry a clear bias against many forms of alterity. For instance, the moment any speaker deploys weather, body, house/home, or other territorial metaphors in the context of talk about migrants, the audience is encouraged to wonder about ways to stop the 'flood', close 'leaks' and 'loopholes', or prevent 'invasions' and 'injuries'. In this way foreigners are symbolically burdened with

\footnotetext{
65 See Ortner (2007), pp. 37-46.

66 See Süss (1993), pp. 217, 223.

67 See Barthes (1972), p. 116.
} 
a wide range of negative outcomes, which are not counterbalanced by similarly compelling and extensively used positive symbols. ${ }^{68}$

Obviously, well-meant cosmopolitan memories of migration are a useful point of departure but will not suffice. We need more radically innovative, agonistically structured memories of mobility to bridge the gap between fact and perception and create political options for inclusivity. ${ }^{69}$ How can we better imagine the migration experiences of the past to help solve perceived migration crises today? How can we rethink the population movements of the world wars, the political migrations of the Cold War, and the labour migrations of the age of European affluence to shape the kind of memories that help us foster rather than derail integration processes? How can we lay the foundations for helpful memories of the war in Syria, the destruction of Iraqi society, the misery of continuous warfare in Afghanistan, and the climate migrations of the future in order to help migrants and their reluctant hosts craft a productive, sustainable life together? ${ }^{70}$

\section{Memory Agonistics. Honouring the Refugee and Forgetting the Migrant}

The interpretive feedback loop is all too real: the memory of past mobility, or lack thereof, does amount to a decisive factor in a given society's ability to welcome newcomers as equals. If you conceive of yourself as being part of a tradition of people on the move, it is much easier to relate to people moving towards you. The plasticity of social memories is similarly real. The field of memory studies has proven time and again that what counts in the realm of collective remembrance is not what actually happened but what people feel and think happened. In this fashion, twentieth century culture has moved mountains. Without having had much help in terms of cultural precedents the mass media turned the most brutal and depressing chapters of World War II, Nazi rule, and forced migration into uplifting stories of heroism, innocence, victimhood, and justice accomplished. ${ }^{71}$ In a kind of secular reformation, the survivors of Auschwitz became figures of public veneration in the arena of popular Holocaust memory. ${ }^{72}$ That example illustrates that the plasticity of collective memory

\footnotetext{
68 See Link (1978), pp. 184-222; Link (2006); Link, Jäger (1993); Thiele (2005).

69 See Bull, Hansen (2016).

$70 \quad$ For climate migration see Mayer (2016).

71 See Fogu, Kansteiner, Presner (2016).

72 See Shenker (2015).
} 
defines an important ethical responsibility. As a society we are accountable for our memories and should choose wisely when it comes to remembering the events and stories that define our collective selves. Unfortunately, remembering responsibly is a complicated affair leading invariably to a troublesome paradox. Migration is an excellent case in point. On the one hand, we should do all we can to remember the plight of people who have escaped hardship. They deserve our respect and empathy. A widely shared memory of their suffering and resolve is a precondition for justice and humanitarian action. On the other hand, migrants are not citizens. For instance, the word "migrant" is hardly a neutral term. By designating a person as deserving of special treatment, the word turns that person into a target of discrimination, pity, and arrogance. So we have to forget the migrant and the migrating experience to extend full-term membership in society to new arrivals. To sideline dysfunctional memories, Europe needs to embrace the figure of the refugee as memory icon and forget the migrant's distinctiveness - all at the same time. How do we reconcile these two sound and seemingly diametrically opposed ethical principles?

Societies have different levels of tolerance for moving people and different capabilities of integrating them after their arrival, among other reasons because they develop different memories of migration. In classic immigration societies like the US and Australia, the troublesome and shameful details of mass exodus and deportation from Europe were swiftly pushed aside by uplifting stories of liberty and self-made prosperity at the expense of indigenous populations. Past suffering and dashed hopes were covered up by inauthentic charades of ethnic folklore and fantasies of national unity, which in turn became a solid foundation for democracy and the rule of law. ${ }^{73}$ European societies handled the large population displacements caused by World War II in similar ways. All across Eastern Europe and Germany, refugees, displaced persons, and the many ideologically uprooted sought coverage under fictions of ethnic homogeneity and political consensus. The forces of integration exerted a great deal of structural violence. Languages, heritage, political discontent, and many unwelcome memories disappeared in relentlessly selective invented traditions. The cultural violence designed to hide past enthusiasm for Nazism, extensive collaboration, and a great number of Nazi perpetrators also helped turn refugees into citizens. An impoverished and destroyed continent managed to find homes for at least 15 million migrants, especially in West Germany, and in later years continued that tradition by welcoming millions of people eager to leave Communist Eastern Europe. Ironically, West Germany and many

73 See Bedad (2005). 
of its neighbours meanwhile maintained the fiction that the countries were not immigration societies. ${ }^{74}$ For that purpose they invented new terms for people on the move, including such creative designations as "belated re-settlers" (Spätaussiedler). ${ }^{75}$ The strategies intended to forget the stigma of migration worked wonders for the cause of integration but turned into memory liabilities when migrants from Southern Europe were encouraged to move to the North and did not receive similarly optimistic long-term perspectives and fanciful designations. One is tempted to conclude that the integration of the 15 million succeeded because they were Germans and therefore naturally belonged to Germany, whereas the much smaller group of Southern European arrivals hailed from another culture and could not be integrated as easily. That explanation underestimates the cultural distance between Königsberg and Bavaria and the cultural diversity among the expellees; ${ }^{76}$ the explanation also underestimates the importance of social scripts and social memory for processes of social integration. If the movement of Turks to West Germany in the 196os had been designated as permanent, inevitable, and based on stories of longterm German-Turkish economic collaboration, the descendants of Turkish immigrants would find themselves in a much different position in German society today.

Honouring the refugee and forgetting the migrant does not have to be a contradiction. Cultural memories are never consistent; they are dynamic, multifaceted, and contradictory. Official institutional memories of migration can celebrate the refugee while more fluid everyday media memories help deconstruct the stark artificial divide between migrants and non-migrants. Now that the survivors of the Shoah are leaving the stage, the refugees should take their place. Having overcome war, human trafficking, and persistent prejudice, they deserve their own memorial sites and prominent didactic presence in schools, museums, and the media. Permanently inscribed in our cultural memories, the figure of the refugee could make sure that we remember their woes and accomplishments and strive to live up to the dictum of "never again!" So we are advocating here for a mobility turn in memory studies and the politics of memory, conceptualising moving people not as deficient vis-à-vis an allegedly static location from which they emerge (emigration) or to which they aspire (immigration). Instead, the process of movement itself becomes the focus of analytical and narrative interest resulting in a wide spectrum of multi-directional memories reflecting a range of nomadic experiences and diasporic feelings that

\footnotetext{
74 See Wilhelm (2017).

75 See Menzel, Engel (2014).

76 See Rock, Wolff (2002).
} 
include such different perspectives as that of the exchange student and civil war refugee without obliterating the dissimilarities between them. ${ }^{77}$ Social and media scripts that acknowledge differences of opinion and interests regarding the movement of people while de-essentialising these differences could lay the foundation for agonistic memories of migration and agonistic debates about the privileges of affluent birth and the limits of human solidarity. What difference should this perspective make for prime time crime? A lot and very little. Television is hardly at the cutting edge of twentyfirst century's media technologies. Future memories of flight and migration will be negotiated in immersive gaming and AI environments. ${ }^{78}$ But let's pretend for a moment that we could rewrite media history. In Leyla and Jungle Brothers script and camera could for instance have stayed with the moving victims and moving perpetrators, rendering their decisions and behaviour complex, intriguing, and plausible. The detectives should have been much more diverse and sported a moving background easy to relate to. Itinerancy, deviancy and helplessness, on the one hand, and settledness, integrity and power, on the other hand, should not have formed such a rigid semantic contrast. If more fluid stories of people movements had been widely spread in primetime crime at the beginning of the new millennium, perhaps the welcoming culture of 2015/16 might have lasted just a little bit longer.

The scripts for better stories of movement can be found in the real world. Between 2013 and 2017 , over $24 \%$ of newly hired police officers in Berlin hailed from a minority background, but the Scene-of the-Crime detectives serving in Berlin, who were hired in 2015, still exude settled whiteness. ${ }^{79}$ The toughest challenge in building new collective memories of movement remains the deconstruction of racism. ${ }^{80}$

\section{Bibliography}

Alsultany, Evelyn (2012). Arabs and Muslims in the Media. Race and Representation after 9/11 (New York: New York University Press).

Anders, Manfred (2003). 'Film verwechselt', Sächsische Zeitung 12 September.

Arzheimer, Kai (2017). 'Electoral Sociology. Who Votes for the Extreme Right and Why and When', in Cas Muddle (ed.), The Populist Radical Right (London: Routledge), pp. $277^{-289}$.

77 See Nail (2015); Sheller, Urry (2006).

78 See de Smale et al. (2017).

79 See Mediendienst-Integration (2017); Tatort-Fundus (2018e).

$80 \quad$ See Kansteiner (2019). 
Arzheimer, Kai (2018). 'Explaining Electoral Support for the Radical Right', in Jens Rydgren (ed.), The Oxford Handbook of the Radical Right (Oxford: Oxford University Press), pp. 143-165.

Bauman, Zygmunt (2106). Strangers at Our Door (Cambridge: Polity).

Barthes, Roland (1972). Mythologies (London: Cape).

Bedad, Ali (2005). A Forgetful Nation. On Immigration and Cultural Identity in the United States (Durham, NC: Duke University Press).

Bohn, Angelika (2003a). 'Spannender Wettlauf', Ostthüringer Zeitung, 28 October.

Bohn, Angelika (2003b). 'Das Organ-Geschäft. Nur ein Teilerfolg erzielt der Tatort Leyla', Ostthüringer Zeitung, 9 February.

Bollhöfer, Bjørn (2007). Geographien des Fernsehens. Der Kölner 'Tatort' als mediale Verortung kultureller Praktiken (Bielefeld: transcript).

Bondebjerg, Ib et al. (eds) (2017). Transnational European Television Drama. Production, Genre and Audiences (Cham: Palgrave Macmillan).

Bonner Generalanzeiger (2003). 'Tödliche Langeweile', 28 October.

Brubaker, Rogers (1996). Nationalism Reframed. Nationhood and the National Question in the New Europe (Cambridge: Cambridge University Press).

Brück, Ingrid, Andrea Guder, Reinhold Viehoff, Karin Wehn (2003). Der deutsche Fernsehkrimi. Eine Programm- und Produktionsgeschichte von den Anfängen bis heute (Stuttgart: Metzler).

Buhl, Hendrik (2014). 'Zwischen Fakten und Fiktionen', in Christian Hißnauer, Stefan Scherer, Claudia Stockinger (eds), Zwischen Serie und Werk. Fernseh- und Gesellschaftsgeschichte im "Tatort" (Bielefeld: transcript), pp. 67-87.

Bull, Anna, Hans Hansen (2016). 'On Agonistic Memory', Memory Studies, 9.4, pp. 390-404.

Connor, Phillip (2017). 'Still in Limbo. About a Million Asylum Seekers Await Word on Whether They Can Call Europe Home', Pew Research Center Global Attitudes \& Trends, 20 September. http://www.pewglobal.org/2017/og/20/a-million-asylumseekers-await-word-on-whether-they-can-call-europe-home/ [accessed 10.08.2017].

De Smale, Stephanie et al. (2017). 'The Case of This War of Mine. A Production Studies Perspective on Moral Game Design', Games and Culture, 8.29, pp. 1-6.

Dietrich, Nico, Wolfgang Frindte (2017). 'Einstellungen zu Muslimen und zum Islam II und der Terrorismus', in Nico Dietrich, Wolfgang Frindte (eds), Muslime, Flüchtlinge und Pegida. Sozialpsychologische und kommunikationswissenschaftliche Studien in Zeiten globaler Bedrohungen (Wiesbaden: Springer), pp. 89-137.

Domaratius, Jana (2009). 'Cultural Diversity Mainstreaming in Türkisch für Anfänger und Alle lieben Jimmy', in Claudia Böttcher, Judith Kretschmar, Markus Schubert (eds), Heimat und Fremde. Selbst-, Fremd- und Leitbilder in Film und Fernsehen (Munich: Peter Lang), pp. 199-214.

Ellinas, Antonis (2018). 'Media and the Radical Right', in Jens Rydgren (ed.), The Oxford Handbook of the Radical Right. (Oxford: Oxford University Press), pp. 269-284. 
Enli, Gunn (2015). Mediated Authenticity. How the Media Constructs Reality (New York: Peter Lang).

Focus-Online (2017). '70 Procent der Deutschen finden, dass der Islam nicht zu Deutschland gehört', 4 October. https://www.focus.de/politik/videos/repraesentat tive-umfrage-70-prozent-der-deutschen-finden-dass-der-islam-nicht-zu-deutschland-gehoert_id_6o27429.html [accessed 21.01.2018].

Fogu, Claudio, Wulf Kansteiner, Todd Presner (eds) (2016). Probing the Ethics of Holocaust Culture (Cambridge, Mass.: Havard University Press).

Frohn, Axel (2003). 'Ulrike Folkerts. Die dienstälteste TV-Kommissarin feiert heute Jubiläum im Tatort Leyla', Berliner Zeitung, 31 August.

Galaktionow, Barbara (2016). 'Holocaust-Überlebende nennt "Wir schaffen das" einen heroischen Slogan', Süddeutsche Zeitung, 27 January.

Gangloff, Tilmann (2003). 'Irgendwann rächt sich alles', Stuttgarter Zeitung, 12 June.

Geddes, Andrew, Peter Scholten (2016). The Politics of Migration and Immigration in Europe. 2nd edn (Los Angeles: Sage).

Gehrmann, Alva (2003). 'Plastikleichen pflastern seinen Weg', Der Tagesspiegel, 15 June.

Gladis, Lea (2016). 'Mapping Stereotypes und Tatort. Aspekte stereotyper Perzeptionen Südosteuropas im 21. Jahrhundert', in Nina Frieß et. al. (eds), Grenzräume - Grenzbewegungen (Potsdam: Universitätsverlag), pp. 49-62.

Goebel, Simon (2017). Politische Talkshows über Flucht. Wirklichkeitskonstruktionen und Diskurse. Eine kritische Analyse (Bielefeld: transcript).

Gorton, Kristyn (2009). Media Audiences. Television, Meaning and Emotion (Edinburgh: Edinburgh University Press).

Hafez, Kai (2017). 'Der Islam in den Medien. Der Islam hat eine schlechte Presse', Zeit Online, 21 February. http://www.zeit.de/gesellschaft/zeitgeschehen/2016-12/ islam-verstaendnis-medien-berichterstattung-populismus-gefahr [accessed 21.01.2018].

Hafez, Kai, Carola Richter (2007). 'Das Islambild von ARD und ZDF', Aus Politik und Zeitgeschichte 26-27, pp. 40-46.

Hamburger Abendblatt (2016). 'Der Tatort wird in rund 50 Ländern ausgestrahlt', 12 November.

https://www.abendblatt.de/wirtschaft/article208704647/Der-Tatort-wird-in-rund-50Laendern-ausgestrahlt.html [accessed 15.01.2018].

Harzenetter, Wilma (1996). Der Held 'Schimanski' in den 'Tatort'-Folgen des WDR. Ein Protagonist der achtziger Jahre (Alfeld: Coppi).

Herzinger, Richard (2003). 'Der Fall Hohmann. Raunen, Angst und Haß', Die Zeit, 13 November.

Heinen, Christina (2003). 'Blut und Boule. Tatort über Antisemitismus', Frankfurter Rundschau, 12 June.

Hickethier, Knut (1998). Geschichte des Deutschen Fernsehens (Stuttgart: Metzler). 
Hißnauer, Christian (2009). 'Fremdes Deutschland. Heimat und Fremde aus der Sicht von Migranten. Hans-Dieter Grabes Dokumentarfilme der 1980er Jahre', in Claudia Böttcher et. al. (eds), Heimat und Fremde. Selbst-, Fremd und Leitbilder in Film und Fernsehen. (Munich: Martin Meidenbauer Verlagsbuchhandlung), pp. 35-46.

Hißnauer, Christian, Stefan Scherer, Claudia Stockinger (eds) (2014). Zwischen Serie und Werk. Fernseh- und Gesellschaftsgeschichte im 'Tatort' (Bielefeld: transcript).

Hoskins, Andrew (ed.) (2018). Digital Memory Studies. Media Pasts in Transition (New York: Routledge).

Kancs, d'Artis, Patrizio Lecca (2017). Long-term Social, Economic and Fiscal Effects of Immigration into the EU. The Role of the Integration Policy. JRC Working Papers in Economics and Finance 4, doi:10.2760/999095.

Kansteiner, Wulf (2006). In Pursuit of German Memory. History, Television, and Politics after Auschwitz (Athens, OH: Ohio University Press).

Kansteiner, Wulf (2011). 'What is the Opposite of Genocide? Philosemitic Television in Germany, 1963-1995', in Jonathan Karp, Adam Sutcliffe (eds), Philosemitism in History (Cambridge: Cambridge University Press), pp. 289-313.

Kansteiner, Wulf (2019). 'Migration, Racism and Memory,' Memory Studies, 12.6, pp. 611-616.

Katz, Jack (1987). 'What Makes Crime 'News?', Media, Culture, and Society, 9, pp. 47-75.

Keding, Karin, Annika Struppert (2009). Ethno-Comedy im deutschen Fernsehen (Leipzig: Frank \& Timme).

Klingst, Martin, Sascha Venohr (2017). 'Wie kriminell sind Flüchtlinge? Was die Kriminalstatistiken der Bundesländer über die Zunahme von Gewalttaten seit 2015 verraten. Sechs Trendmeldungen zur Zuwanderungskriminalität', Zeit Online, 19 April. http://www.zeit.de/2017/17/kriminalitaet-fluechtlinge-zunahme-gewalttatenstatistik [accessed 10.09.2017].

Kretzschmar, Sonja (2002). Fremde Kulturen im europäischen Fernsehen. Zur Thematik der fremden Kulturen in den Fernsehprogrammen von Deutschland, Frankreich und Großbritannien (Wiesbaden: Westdeutscher Verlag).

Krüger, Udo (2002). Programmprofile im dualen Fernsehsystem 1991-2000 (BadenBaden: Nomos).

Kwasnieski, Nicolai (2017). 'Wie Gehalt, Beruf und Wohnort die Wahlentscheidung prägen', Spiegel Online, 19 July. http://www.spiegel.de/wirtschaft/soziales/bundestagswahl-2017wer-waehlt-cdu-csu-spd-fdp-gruene-linke-afd-a-1158543.html [accessed 30.01.2018].

Lind, Rebecca Ann (2010). Race/Gender/Media. Considering Diversity Across Audiences, Content, and Producers. 2nd edn (Boston: Pearson).

Link, Jürgen (1978). Die Struktur des Symbols in der Sprache des Journalismus. Zum Verhältnis literarischer und pragmatischer Symbole, (Munich: Fink).

Link, Jürgen (2006). Versuch über den Normalismus. Wie Normalität produziert wird. 3rd edn (Göttingen: Vandenhoeck \& Ruprecht). 
Link, Jürgen, Siegfried Jäger (eds) (1993). Die vierte Gewalt. Rassismus und die Medien. (Duisburg: Duisburger Institut für Sprach- und Sozialforschung).

Lochocki, Timo (2018). The Rise of Populism in Western Europe. A Media Analysis of Failed Political Messaging (Cham: Springer).

Magalhaes, Pedro (ed.) (2015). Financial Crisis, Austerity, and Electoral Politics. European Voter Responses to the Global Economic Collapse 2009-2013 (New York: Routledge).

Mackuth, Margret (2007). Es geht um Freiheit. Interkulturelle Motive in den Spielfilmen Fatih Akins (Saarbrücken: Akademikerverlag).

Mayer, Benoît (2016). The Concept of Climate Migration. Advocacy and Its Prospects (Cheltenham: Elgar).

Mediendienst-Integration (2017). 'Beamte mit Migrationshintergrund. Wie entwickelt sich die Vielfalt bei der Polizei?', ı. https://mediendienst-integration.de/fileadmin/ Dateien/Polizisten_mit_Migrationshintergrund_2017.pdf [accessed 05.02.2018].

Menzel, Birgit, Christine Engel (eds) (2014). Rückkehr in die Fremde. Ethnische Remigration russlanddeutscher Spätaussiedler (Berlin: Frank \& Timme).

Mertens, Stefan, Hedwig de Smaele (eds) (2016). Representations of Islam in the News. A Cross-Cultural Analysis (Lanham, MD: Lexington Books).

Moray, Peter, Amina Yaqin (2011). Framing Muslims. Stereotyping and Representation after 9/11 (Cambridge MA: Harvard University Press).

Mously, Sara (2007). Heimat im Fernsehen. Eine medienpsychologische Untersuchung am Beispiel des "Tatort”. (Saarbrücken: VDM).

Nail, Thomas (2015). The Figure of the Migrant (Stanford: Stanford University Press).

Noelle, Elisabeth, Thomas Petersen (2006). 'Allensbach-Analyse. Eine fremde, bedrohliche Welt', Frankfurter Allgemeine Zeitung, 17 May.

Ortner, Christina (2007). Migranten im Tatort. Das Thema Einwanderung im beliebtesten deutschen TV-Krimi (Marburg: Tectum).

Rings, Guido (2016). The Other in Contemporary Migrant Cinema. Imagining a New Europe? (New York: Routledge).

Rock, David, Stefan Wolff (eds) (2002). Coming Home to Germany? The Integration of Ethnic Germans from Central and Eastern Europe in the Federal Republic since 1945 (New York: Berghahn).

Rooduijn, Matthijs (2016). 'Closing the Gap? A Comparison of Voters for Radical Rightwing Populist Parties and Mainstream Parties', in Tjitske Ackermann et al. (eds), Radical Right-Wing Populist Parties in Western Europe. Into the Mainstream? (New York: Routledge), pp. 53-69.

Rudolph, Ulrich (2007). Die Visualität der Teilsysteme. Intersubjektivität der Wahrnehmung visueller Symbole am Beispiel einer Tatort-Filmreihe (Marburg: tectum).

Sauerwein, Uwe (2003). 'Tatort-Krimi gegen Antisemitismus. Der Schächter dreht sich um die uralte Legende vom Ritualmord', Berliner Morgenpost, 7 December. 
Shandler. Jeffrey (1999). While America Watches. Televising the Holocaust (New York: Oxford University Press).

Sheller, Mimi, John Urry (2006). ‘The New Mobilities Paradigm', Environment and Planning, 38, pp. 207-226.

Shenker, Noah (2015). Reframing Holocaust Testimony (Bloomington, IN: Indiana University Press).

Spencer, Sarah (ed.) (1994). Immigration as an Economic Asset. The German Experience (London: Trentham).

Spielberger, Christoph (2012). 'Befehl des NDR. Cenk Batu muss erschossen werden', achgut.com, 7 May. [accessed 31.01.2017].

Spohn, Willfried, Klaus Eder (eds) (2005). Collective Memory and European Identity. The Effects of Integration and Enlargement (London, New York: Routledge).

Süss, Daniel (1993). Der Fernsehkrimi, sein Autor und die jugendlichen Zuschauer (Bern: Huber).

Statistisches Bundesamt (2021). 'Migration und Integration,' 29 March. https://www. destatis.de/DE/Themen/Gesellschaft-Umwelt/Bevoelkerung/Migration-Integration/_inhalt.html (accessed 02.04.2021).

tatort-fans.de (2021). https:// tatort-fans.de (accessed 02.04.2021).

Tatort-Fundus (2018a). 'Folgen' http://www.tatort-fundus.de/web/folgen.html [accessed 15.02.2018].

Tatort-Fundus(2018b).'Reifezeugnis'.http://www.tatort-fundus.de/web/folgen/chrono/ 1/1977/o73-reifezeugnis.html [accessed o8.07.2010].

Tatort-Fundus (2018c). 'Batu'. http://www.tatort-fundus.de/web/ermittler/sender/ndr/ batu.html [accessed 31.01.2018].

Tatort-Fundus (2018d). 'Ermittler'. http://www.tatort-fundus.de/web/ermittler/ alphabetisch-sortiert.html [accessed 02.02.2018].

Tatort-Fundus (2018e). 'Nina Rubin und Robert Karow'. http://www.tatort-fundus. de/web/ermittler/sender/rbb-rundfunk-berlin-brandenburg/karow-rubin.html [accessed 02.02.2018].

Thiele, Matthias (2005). Flucht, Asyl und Einwanderung im Fernsehen (Konstanz: UvK Verlagsgesellschaft).

Trebbe, Joachim (2009). Ethnische Minderheiten, Massenmedien und Integration (Wiesbaden: VS Verlag).

Trenz, Hans-Jörg (2016). Narrating European Society. Towards a Sociology of European Integration (Lanham, MD: Lexington Books).

UNHCR, The UN Refugee Agency (ed.) (2016). Global Trends. Forced Displacements 2015 (Geneva: UNHCR).

UNHCR, The UN Refugee Agency (ed.) (2017). Global Trends. Forced Displacements 2016 (Geneva: UNHCR).

Wallnöfer, Pierre (2003). 'Lügen wie gedruckt', Salzburger Nachrichten 28 October. 
Wehn, Karin (2002). 'Crime-Time' im Wandel. Produktion, Vermittlung und Genreentwicklung des west- und ostdeutschen Fernsehkrimis im Dualen Rundfunksystem (Bonn: ARCult-Media).

Wellgraf, Stefan (2008). Migration und Medien. Wie Fernsehen, Radio und Print auf die Anderen blicken (Berlin: Lit).

Wilhelm, Cornelia (ed.) (2017). Migration, Memory, and Diversity. Germany from 1945 to the Present (New York: Berghahn).

Winter, Renee (2015). 'Tatort', in Wofgang Benz (ed.), Handbuch des Antisemitismus. Judenfeindschaft in Geschichte und Gegenwart, Bd.7. Literatur, Film, Theater und Kunst (New York, Berlin: de Gruyter), pp. 484-486.

WorldBank(2017).'DataEuropeanUnion'.https://data.worldbank.org/region/europeanunion [accessed 08.10.2017]. 


\title{
Stereotyping by Default in Media Transfer
}

\author{
Luc van Doorslaer
}

\begin{abstract}
This contribution looks at the added value that journalistic discourse and approaches from translation studies can offer to imagology. Translation studies nowadays is a discipline no longer dealing with interlingual transfer only, but also with intralingual as well as intercultural communication transfer and all changes involved in processes of rewriting and adaptation. A great deal of journalistic production is the result of such processes of rewriting and recontextualising. Journalistic translation research has paid attention to this by coining terms such as 'transediting' or 'journalator', indicating the overlap between the activities and the actors. Acts of recontextualising inevitably deal with the transfer of (national and cultural) images and stereotypes, as well as the conscious and unconscious changes involved. In modern media societies journalistic discourse is highly influential in producing and distributing national and cultural stereotyping. Under certain circumstances stereotyping is likely to function by default in journalism, the so called 'automaticity of stereotyping'. This phenomenon is illustrated with several examples from journalistic discourse. They are frequently found in sports journalism, but this contribution also offers examples from political journalism related to the presentation of Germany and Europe.
\end{abstract}

\section{Introduction}

One of the fascinating characteristics of imagology is its relative intangibility. Studying national and cultural images and ethnotypes could have the potential of being a discipline or subdiscipline. But as imagology lacks the necessary institutionalisation level, it cannot be considered a discipline or even subdiscipline. Sometimes it is called a "working method"1. However, I'm not aware of a general handbook of methodology specifically mentioning imagology. Though an imagological approach complies with the classical features of adopting a method (systematicity of investigation, a mode of procedure, etc.), it is never

1 Leerssen (2016), p. 19.

(C) LUC VAN DOORSLAER, 2021 | DOI:10.1163/9789004436107_012

This is an open access chapter distributed under the terms of the CC BY-NC-ND 4.0 license. 
put at a similar level with methods such as discourse analysis, corpus gathering, keystroke logging, eye tracking, interviews or surveys. Imagology rather functions as a selection principle, it is a lens through which the material is studied, a perspective functioning as a criterion for selecting the potentially relevant material. Such a lens can be adopted with the help of several methods. An imagological lens can be applied through text analysis or interviews, an imagologically based selection is possible with corpora or eye tracking. If imagology is considered this way, the relatively recent extension of imagology to other than literary discourse may be considered a natural development. ${ }^{2}$ More in particular, this contribution elaborates on the added value that materials and approaches from journalistic discourse and translation studies could offer to imagology. Such a possible input will be illustrated with several examples.

\section{The Potential Added Value of Journalism Studies}

It is obvious that the huge amount of research on representation in journalism studies and the study of stereotypes have certain aspects in common. ${ }^{3}$ On the other hand imagology's focus on the function of literary and cultural transfer in ethnotyping, in combination with its attention for diachrony, shows a much more specific object and approach. The origins of imagological research in literary studies have also contributed to an emphasis on the richness of literary discourse in this regard. Joep Leerssen has rightly stressed the importance of literary canonicity strengthening the perception of ethnotypes, thereby considering other text types, such as journalism, as "more ephemeral sources". ${ }^{4} \mathrm{On}$ the other hand, in our modern media world journalistic discourse is omnipresent. Despite its undeniably ephemeral character, the feature of constant repetition of certain (national and cultural) stereotypes in the media may achieve an effect similar to canonisation. Looking at it from this perspective, it might be worthwhile addressing the relative underrepresentation of journalistic discourse in imagology.

This underrepresentation is indeed relative, not absolute. Some studies have already shown the potential imagological relevance of journalistic sources. This is explicitly done by Corinne Fowler (2007) where she investigates the role of journalism in the development of British ideas about Afghanistan. The

\footnotetext{
2 For instance in van Doorslaer (2010) or van Doorslaer (2012).

3 One example explicitly connecting representation with discourses of identity and Self-Other rhetoric is Le (2006).

4 Leerssen (2007), p. 26.
} 
British news media coverage about the 2001 conflict relied on "heavily fictionalised and mythologised notions of Afghanistan". ${ }^{5}$ Interestingly, Fowler shows how the journalists copied - and as such also confirmed - centuries-old clichés that were transmitted through journalistic accounts and travel narratives.

Casting its net deep into the nineteenth century, the study investigates how British travellers and journalists continue to inherit the paranoias and prejudices of their nineteenth-century predecessors and why, in British imaginations, Afghans tend to remain warlike, medieval, murderous and unruly. ${ }^{6}$

It is no coincidence, particularly in historical research, that travellers and journalists are mentioned on equal footing. Travel writing and travel journalism form a productive mixed genre for clichés and national or cultural stereotyping, as they register otherness and explore "individual and national identity. [...] travel writing is almost invariably about Self and Other". ${ }^{7}$ Lily Coenen's study (2013) on the image of Spain in Dutch travel writing is an example showing the development and variety of such image-building over a century of time, and how the authors were intertextually influenced by the readings of literary fiction and figures functioning as "floating signifiers". ${ }^{8}$ Intertextuality is not only a feature of literary, but also of journalistic discourse. Discursive reflections of otherness, or at least the way otherness is perceived, is the heart of the matter of imagological research. Against this background it is also relevant that Coenen stresses the interdependency of hetero- and auto-images: the changes in the perception of Spain were often related to a projection need of the Dutch authors.

This reminded me of similarities with a research project on 'Literary Travel Journalism' I conducted with students of a Master's seminar at KU Leuven a few years ago. Though the results were never published because of the small scale of the project, they are interesting in this context. The students investigated contemporary travel journalism about South Africa in Dutch-language sources, both from the Netherlands and Belgium (Flanders). The 16 examples in the corpus were all longer texts with literary characteristics. The analysis of the varying foci and topics showed that there was a considerable difference between the approach of the articles published in the Netherlands and

\footnotetext{
5 Fowler (2007), p. 4.

6 Fowler (2007), p. 4f.

7 Coenen (2013), p. 8.

8 Coenen (2013), p. 177 .
} 
in Flanders. The Dutch authors made use of much less historical facts and focused on modern post-apartheid South Africa. The Flemish authors, on the other hand, used a much more historicising and contrastive approach, referring to racial, social, political and linguistic conflicts in the so called Rainbow nation - the term coined by the South-African Archbishop Desmond Tutu. A hypothesis for further research could be: even within the same Dutch-language area, the auto-image of the travel author is more determining for the approach of the object than the hetero-image. In this case it would mean that the Flemish authors, living in a country (Belgium) with a history (and sometimes present) of frequent political tensions due to language issues, tend to project these contrastive categories on the description and explanation of other countries as well. Whereas the Dutch authors, living in an officially monolingual country much less determined by language issues, adopt a less contrasting approach. Or in alternative imagological terms: the chosen perspectives may tell us more about the spectant (the author representing the represented) than about the spected, the represented country that is the actual object of the article.

Although imagology up to now has primarily studied literary representation, more journalistic types of discourse such as travel writing - "a type of text or genre that has received much more attention than earlier and has moved from the periphery much closer to the centre of current academic discourse" - enable and facilitate a media-oriented extension of the research object. ${ }^{9}$ This would also reflect the crucial role mass media in modern societies have in the expression of cultural identities: "it is uncontested that radio and television [...] have played a central role in the dissemination of national culture, national values and national stereotypes."10

Moreover, there are interesting interdisciplinary connections possible between imagology and some of the journalism studies research on representation and stereotyping. An example would be the research by Dominic Lasorsa and Jia Dai (2007) on (intentional or unintentional) default stereotyping as well as the "overabundance of nationality-related stereotypes" in the writing of deceptive news stories. ${ }^{11}$ According to their study, the less journalists are informed, the more they stereotype. Where gaps have to be filled in in journalistic production (a daily practice), it regularly happens that stereotypes are taken over from hear-say or from earlier news items.

$9 \quad$ Zacharasiewicz (2009), p. 26.

10 Göttlich (2007), p. 356.

11 Lasorsa, Dai (2007), p. 292. 
All these perspectives suggest that in the presence of a mass of potential facts, stereotyping tends to occur to streamline work and ease the perceiver's discrepancy between what is expected and observed. Unless a perceiver is able and motivated not to stereotype, stereotyping is likely to function by default, a process psychologists call automaticity.12

This phenomenon of the automaticity of stereotyping in journalism, as an element in the journalistic process of streamlining work and content in the chaos of facts, would deserve to be related to imagological insights such as the oppositionality of ethnotyping or the ways in which Self-Other oppositions are implied or invoked. ${ }^{13}$

One of the elements essentially linking up the previous examples from travel writing, literary travel journalism or the automaticity of stereotyping, is the determining position of the author. "One of the basic insights in image studies is that the mechanism of the representation of foreign nations can only be analysed properly if we take the attitude of the author into account."14 Besides the elements of cross-fertilisation between imagology and translation studies already dealt with elsewhere, ${ }^{15}$ such as the descriptive and diachronic viewpoints or the centrality of change and hybridity, indeed, also the role of the author in the discursive variation of representation is a fundamental common feature. A translator is undeniably a cultural mediator, "an informant who transfers cultural knowledge from a primary context to a secondary one"16 and who also authors a new text. The literary publishing world creates the illusion that we read Franz Kafka when we read 'The Castle' in English, but in reality 'The Castle' is a text of which Kafka has not written one single word, but is a re-creation of the English translator. The illusion is based on the obsolete model that languages are equivalent structures as well as on the romantic concepts of originality, the unique authority of the source text ('original') and the source text author.

\footnotetext{
12 Lasorsa, Dai (2007), p. 281. Italics in original article.

13 Compare for instance with Leerssen (2016), p. 17.

14 Leerssen (s.d.).

15 See van Doorslaer, Flynn, Leerssen (2015), pp. 2-4.

$16 \quad$ Keller (2007), p. 357.
} 
Journalistic translation research over the past two decades has been a case in point showing that such a model does not correspond to modern reality any longer - if it ever really has before. ${ }^{17}$ Not only are languages never equivalent structures, the daily practice of international journalism also illustrates both the ubiquity and the complexity of the multiplication of source texts and multi-authored journalistic texts. ${ }^{18}$ In such a complex writing and rewriting situation of text production, both intra- and interlingual, translation in the journalistic field not only disintegrates the status of the source text, it also problematizes the very concept of traditional authorship..$^{19}$ It is no coincidence that research on translation in journalism has led to the coinage of hybrid terms such as 'transediting' ${ }^{20}$ or 'journalator,'21 indicating the blurred borders between translating and (journalistic) authoring. In systemic terms, the rewriting, re-editing and recontextualising practices in journalism could be considered an example of "intrasystemic translations" within the journalistic system. ${ }^{22}$

Exactly this hybridity and complexity of the author status is also important from an imagological perspective with regard to the above mentioned attitude of the author. Interlingual translation, and even more so intralingual and intersemiotic translation, ${ }^{23}$ offers the author-translator an extra filter in the rewriting or re-conveying of images. When translation is no longer traditionally looked at in terms of non-change, but as an element in a chain of textual, contextual and intertextual change, it contributes to the diversification of stereotyping as well.

The non-change paradigm has therefore been subverted by recognising the impossibility of total invariance or full equivalence not only in translation practice, but also and above all in the scholarly study of translation. [...] Observations and descriptions of the reality of translation showed many practices and circumstances that were based on anything but non-change. The inevitability of translators' choices, cultural context, ideological influences, role of agency and idiosyncrasy, multilingual pro-

\footnotetext{
17 See the overview articles Valdeón (2015) and Davier, Schäffner, van Doorslaer (2018).

18 See for instance Schäffner (2012).

19 Van Doorslaer (2010), p. 181f.

$20 \quad$ In Stetting (1989).

21 In van Doorslaer (2012).

22 D'hulst (2008), p. 85.

23 Three types of translation already distinguished in Jakobson (1959).
} 
cessing in newsrooms, travel and migration as translational phenomena, transfer of national and cultural images through translation - these are all examples of situations where translation is fundamentally involved in a (much more than interlingual) process of change. As change inevitably puts more emphasis on contrasts and dissimilarities, elements of difference have complemented the traditional focus on sameness. ${ }^{24}$

An example of this potential power of translation for the distribution of images is the discussion in China about the 'correct' dissemination of Chinese culture through English translations, including the question whether this can be executed better by English native translators or by native Chinese. ${ }^{25}$ The attitude of the author-translator is the heart of the matter in this discussion. This Chinese case of auto-image-building illustrates the use of translation for selecting and highlighting certain features, a well-known principle in the rhetoric of ethnotyping with the help of certain "characteristics presented as being meaningfully representative of the nation". ${ }^{26}$ A notorious historical example illustrating the double-sidedness or power of translating mediators is that of La Malinche or Doña Marina, the (among other things) local interpreter of Spanish conquistador Hernán Cortés. ${ }^{27}$

\section{$4 \quad$ Journalistic Illustrations}

Case studies explicitly dealing with journalistic discourse in translation can be found in several chapters of Interconnecting Translation Studies and Imagology. ${ }^{28}$ Maria Cristina Caimotto studies news translation practices as well as projected self-images between the UK and Italy in the 1970s. ${ }^{29}$ Both Roberto Valdeón and Denise Filmer combine their analysis with the concept of framing. Valdeón's case shows the combination of more modern and more traditional, negativised images about Spain in El País English Edition..$^{30}$ Filmer criticizes the British journalists for framing Italy through reinforced stereotypes of

\footnotetext{
24 Van Doorslaer (2018), p. 222.

25 See for instance $\mathrm{Hu}(2 \mathrm{O15})$.

26 Leerssen (2016), p. 17.

27 See for instance Keller (2007), p. 358 or Valdeón (2013).

28 Van Doorslaer, Flynn, Leerssen (2015).

29 See Caimotto (2015).

30 See Valdeón $(2015 \mathrm{~b})$.
} 
former prime minister Silvio Berlusconi, using translation as "an ideological prop" to intensify certain news narratives. ${ }^{31}$

The fact that national categories are top-of-mind in journalistic categorisations, is nothing new in itself. Already Michael Billig extensively showed the ubiquity of "banal nationalism" in journalistic discourse. ${ }^{32}$ Not extreme, but daily signs of national identity are continuously "flagged in the media": 33 in the use of flags, us and them discourse on national grounds, national museums, the weather forecast presented on national maps, etc. Within the journalism sections, a leading exponent of the continuation and confirmation of banal nationalism is sports journalism: "the sporting pages repeat the commonplace stereotypes of nation, place and race". ${ }^{34}$ An interesting study concentrating on exactly that topic, the national stereotyping in sports journalism, was conducted by Maarten van Bever. Despite being a Master's thesis, the investigation was very well focused and methodologically sound. Van Bever analysed three popular Dutch-language Belgian newspapers in the summer of 2008, particularly focusing on national stereotyping during the European Football Championship played in Austria and Switzerland. The three countries with the highest number of stereotypes were the Netherlands, Germany and Spain. Whereas the neighbouring fans of the Netherlands were often presented as partying, loud, self-confident, sometimes arrogant (all existing stereotypes about the Dutch in Belgium), even more interesting were the references used for describing the finalists Spain and Germany, supposedly the two best teams of the tournament. The representation of Spain stressed the technical aspects of their way of playing, the frivolous and tiki-taka features, but was also connected with emotionality as well as southern and relaxed characteristics. In the case of Germany however, several of the 81 stereotypes in the corpus referred to solidity, power, strength, Sturm und Drang, and no less than nine of them to a war context (e. g. Poland, nazis, Anschluss).

A more recent (unpublished) small-scale study has yielded similar results that can be related to national image-building. A Master student compared the use of typifying words of two teams that were coached by the Spanish-Catalan football coach Pep Guardiola. Although among football specialists it is generally accepted that the way of playing of both Barcelona and Bayern Munich in their Guardiola era was very similar, the corpus showed that terms such as 'machine' or 'bulldozer' were several times used for Bayern, but never for

\footnotetext{
$31 \quad$ Filmer (2015), p. 272.

$32 \quad$ See Billig (1995).

33 Billig (1995), p. 119.

34 Billig (1995), p. 120.
} 


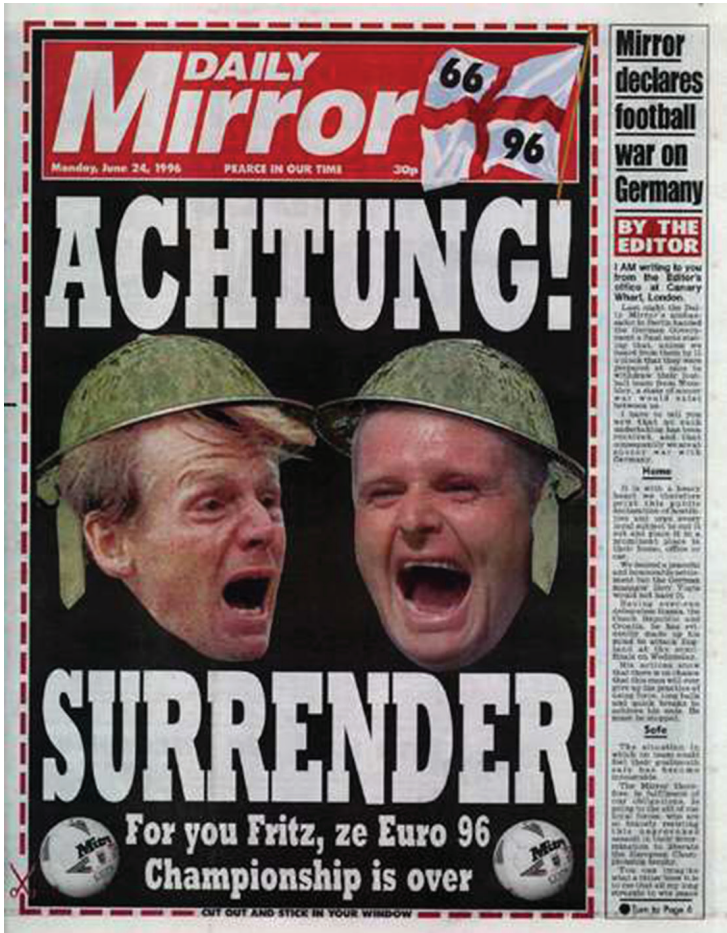

FIGURE 10.1

Front page of the Daily Mirror, 24 June 1996

Barcelona. Lasorsa and Dai's automaticity of stereotyping seems to be omnipresent in sports journalism.

The fact that Germany is an interesting example for imagological research, is in itself not new. Several chapters in Imagology Revisited thematised the image of Germany in America from a historical perspective, for instance. ${ }^{35}$ But the combination of popular press and sports has the potential to intensify and magnify simple images. Well-known was also the Euro 1996 organised in and by England, especially the semi-final between England and Germany. The coverage of that match has been described "as the lowest point in British press coverage of football" 36 . The most famous and extensively discussed front page was that of the Daily Mirror (see fig. 10.1), featuring two English players wearing helmets and the editor declaring the football war on Germany. Despite the newspaper announcing that the Euro 96 would be over for 'Fritz', two days later Germany eliminated England and went on to the final to become the European champions.

35 See Zacharasiewicz (2010).

36 Mark Christopher Watkin, cited in Belam (2008). 
Such "patriotic frenzy" over sports topics can become constitutive for the intensification and automaticity of stereotyping through the media. ${ }^{37}$ "A nation's image, usually constructed in great part by and through the media, can become, over time, part of a national political culture."38 Also Jonathan Grix and Chantal Lacroix (2006) have worked on the case of Germany and the way its image was (re)constructed by the British press after the Second World War. Although they distinguish eight different stereotypes, the one that is by far outnumbering all others is the war-related stereotype. Despite the ephemeral feature of media discourse, its massive presence as well as the repetitive character of the stereotypes can be very powerful in the distribution of clichés.

It is thus clear that the media plays a major role in shaping UK citizens' image of Germany. The school curriculum does not appear to have enough space and time to counter-balance the avalanche of stereotypical coverage of Germany and Germans on television or in the print media. Thus, the outmoded image of Germany presented in the media goes unchecked by any other source that may allow people the chance to correct or adjust their perception of Germany and Germans. ${ }^{39}$

This example illustrates again that the constant repetition of stereotypes is the media's effective weapon that compensates its ephemerality and leads to effects that can be considered similar to canonicity. On top of that, because of the fast production and rapid distribution features of modern online and social media, the repetition is even multiplied.

Although sports coverage may intensify nationalistic and stereotyping tendencies, it is certainly not the only media section making use of the strong emotional potential of simplified national images. Related to the focus on Germany in this part would be examples of political media coverage such as the financial crisis in Greece or the political clashes between the Turkish Erdoğan regime and several Western European countries. In line with the football war references in the British tabloids, the reduction of Germany's past to the nazi regime was frequently employed in the Greek and Turkish media. This is illustrated in fig. 10.2, dating from 2017, when Germany was harshly criticised in the Turkish press because of the cancellation of Turkish ministers' election rallies in Germany.

\footnotetext{
$37 \quad$ Belam (2008).

38 Grix, Lacroix (2006), p. 373.

39 Grix, Lacroix (2006), p. 388.
} 


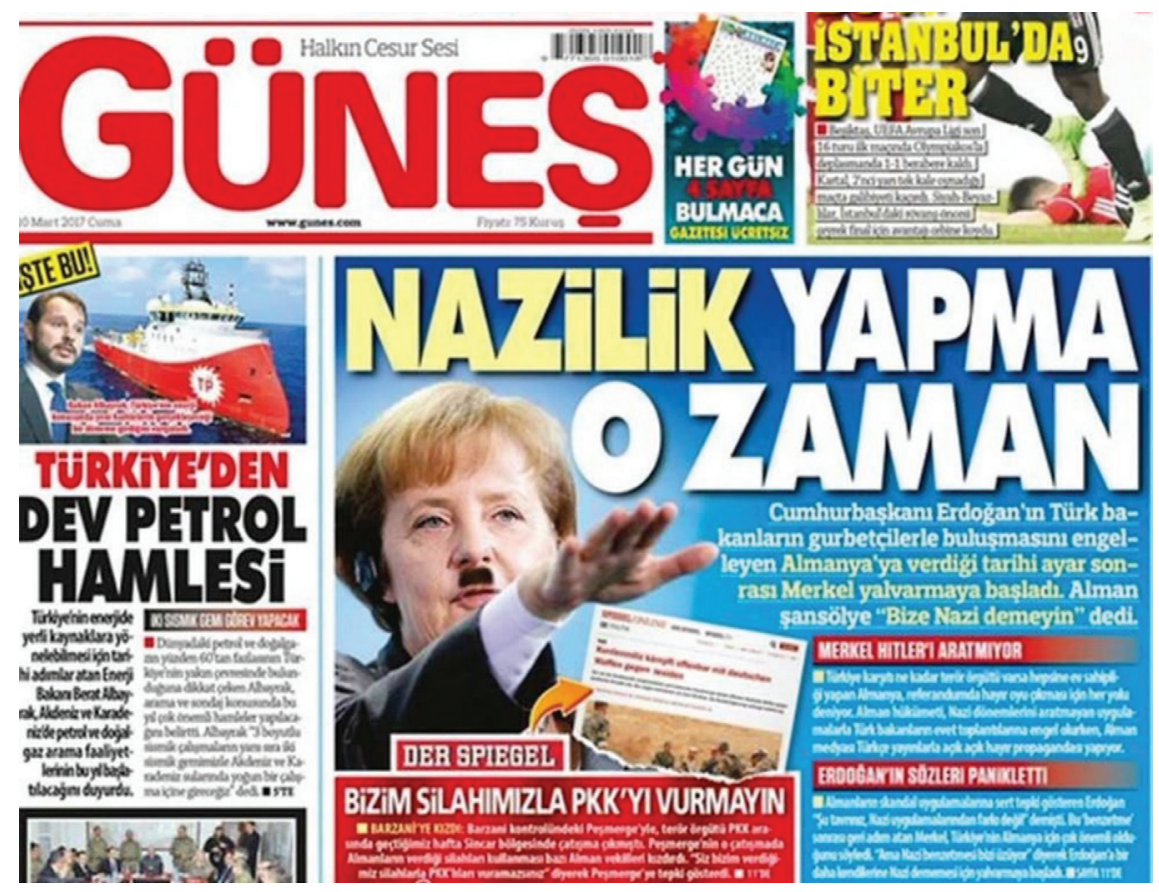

FIGURE 10.2 German Chancellor Angela Merkel presented as Hitler in the Turkish newspaper Güneş

Journalistic discourse is a rewarding object of research for imagology, since some journalistic practices reinforce one-sidedness as an element of the automaticity of stereotyping. The representation of Germany (or Germans) is a case in point. Out of the range of historically available national images, in European media it is for instance not the (eighteenth and nineteenth-century) land of poets and philosophers that is referred to. In topics with an economic or financial content, the industrial or technological power is often stressed, dating back to the end of the nineteenth century, the German Gründerzeit. But by far the most frequently used image relates to the period of the two world wars and the nazi regime in the 1930 and 40 . The reduction is obvious in temporal terms, as this period (if one includes WW I) covers less than three decades in a centuries-old history. Historical reduction and one-sidedness in image-building go hand in hand.

The effect of repetition in journalism is also reinforced by the use of dichotomous categories. An oppositional, occasionally black and white presentation belongs to the toolbox of every communicator who has to present a complex situation to a larger audience. But if such a simplified presentation is successful, it can become ingrained and difficult to correct at a later stage. An example is the 


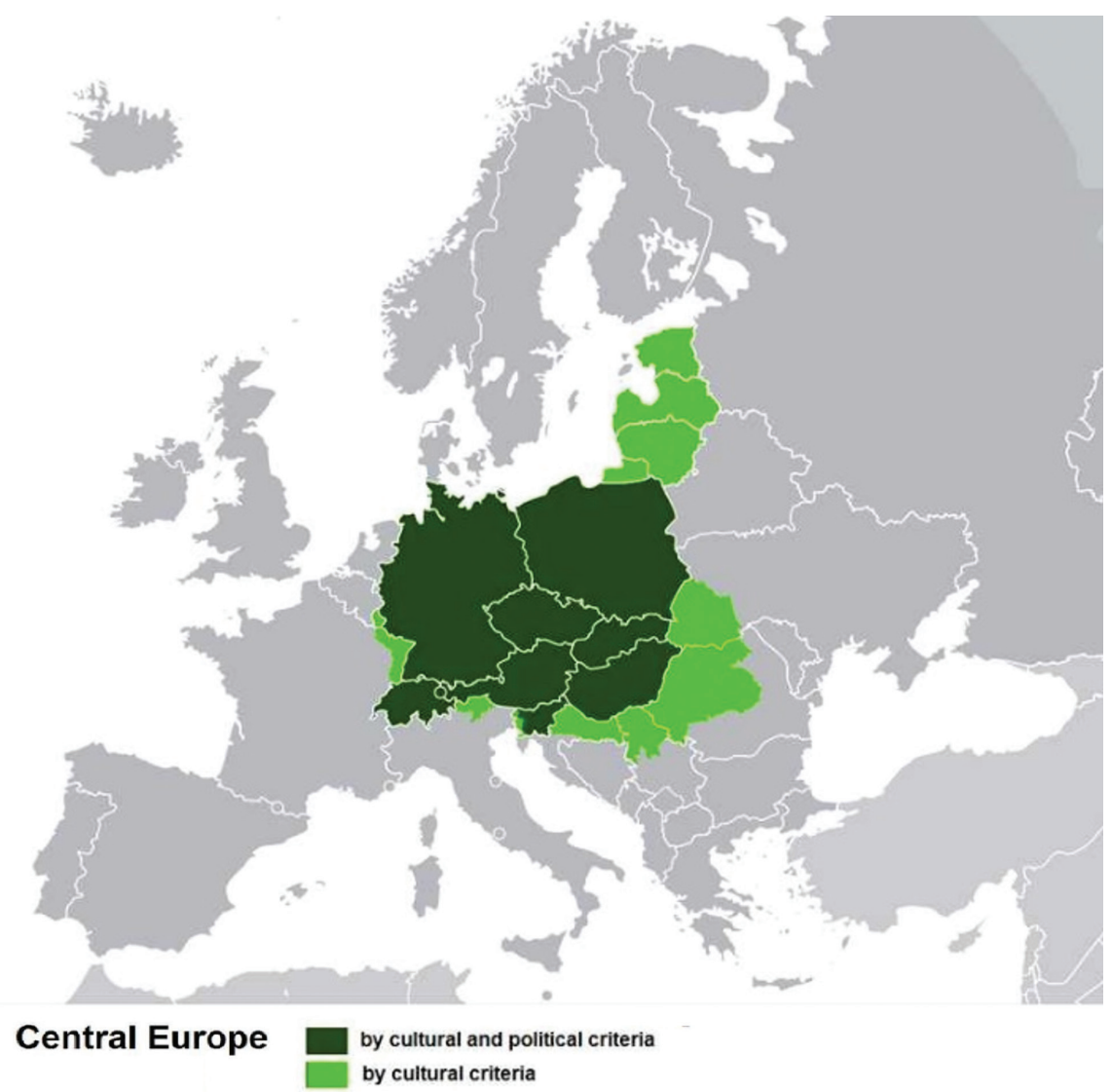

FIGURE 10.3 Central Europe by political as well as cultural criteria

division of Europe in two categories: Eastern vs. Western Europe, referring to the Cold War era and the Iron Curtain. It is a distinction that is frequently, almost automatically made in journalistic discourse. This is remarkable, taking into consideration that the Iron Curtain does not exist anymore for more than thirty years. Nevertheless it still seems to be the determining element for a simplified division of the European continent, including the connotations of East and West that also refer to Cold War commonplaces. A more nuanced, trans-dichotomous, but also fuzzier concept such as 'Central Europe' is hardly used. Central Europe does not have clear borders marked by an Iron Curtain, but is a term with a combination of historical, cultural and political content. A map illustrating this poly-interpretability is included in the Wikipedia page about Central Europe, referring to the Leibniz Institute for Regional Geography as its source. ${ }^{40}$

40 Two emails sent to the Leibniz Institute for Regional Geography asking for more information about the map remained unanswered. 
Whereas political criteria would place Central Europe perfectly within the present political borders of Austria, the Czech Republic, Germany, Hungary, Poland, Slovakia, Slovenia and Switzerland, cultural and historical criteria also include parts of several other countries, taking into account that these regions were part of the former German empire, the Austro-Hungarian monarchy or the Polish-Lithuanian Commonwealth. Just like the Iron Curtain, these are historical situations that are no longer valid. It is mainly the fuzziness of the borders that makes the concept of Central Europe much less attractive for journalistic use than the bi-polarity of Eastern vs. Western Europe.

The choice for a specific presentation or framing is immediately related to the auto-image of Europe, a topic that was mainly elaborated in a Dutchlanguage book by Leerssen (2011). The oppositional pattern of Eastern vs. Western Europe relies on a relatively limited period during the twentieth century on which basis European ethnotypes are constructed: "Eastern locations are often linked to despotic regimes, western ones to democratic values." ${ }^{21} \mathrm{~A}$ counterforce to the East-West dichotomous presentation is for instance the Visegrád group, founded in 1991. It is a cultural and political alliance between the Czech Republic, Hungary, Poland and Slovakia. Its name is based on historical and cultural grounds, referring to a congress in the Middle Ages in the same location. Interestingly this collaboration starts from an idea of strength and collaboration of Central European states, which theoretically would have the potential of replacing an East-West narrative by a Centre-Periphery narrative. At the beginning of 2018, the new conservative government of Austria explicitly mentioned the wish to collaborate more intensely with the Visegrád countries. Although this was mainly based on common ideas about migration policy, at the same time it was a symbolic challenge of the still dominant Iron Curtain division: a 'western' country showing its preference for collaboration with 'eastern' partners. A nineteenth and twentieth century-based cultural and political reality of Austro-Hungarian collaboration pushed aside the more recent Cold War division, with both of those periods having resorted to instances of ethnotyping.

Despite the stereotypical potential of bordering based on wind directions, the arbitrariness of such separations is also shown by other examples. In the north of Europe, the term 'Central Europe' is often used as part of a northsouth presentation, meaning the central part between north and south. And the Baltic Sea is called 'Ostsee' [Eastern Sea] in German, but 'Läänemeri' [Western Sea] in Estonian. Assigning intra-European ethnotypical characteristics becomes almost a haphazard exercise in such cases. 


\section{Conclusions}

Imagological research may sometimes be criticised for focusing on national or cultural essentialisms. Recently Leerssen ${ }^{42}$ has convincingly demonstrated why such views are misguiding. ${ }^{43}$ Although the nation-state is no longer a selfevident category in many scholarly disciplines, national and cultural ethnotyping are ubiquitous in other types of discourse. We have seen that in journalism, stereotyping can be an automaticity. National boundaries are sometimes used as tools to explain or demarcate phenomena that are older and more complex. The border between the Netherlands and Belgium, for instance, is often described in the press as not only a state, but also a religious frontier: the protestant North (the Netherlands) vs. the catholic South (Belgium). On this basis, ethnotypical differences of mentality between the Dutch and the Belgians are constructed and reinforced. But the state border between the two countries has never been the religious boundary. Approximately the south-eastern third of the Netherlands for centuries has been predominantly catholic, just like Belgium. It shows that national - or in this case state - borders are erroneously used as explanatory categories for phenomena that are older than the boundaries themselves.

The dominance of national categorisation for research, particularly for the selection of units of analysis or comparison, has been problematised in several scholarly disciplines. ${ }^{44}$ However, in journalistic discourse the predominance of national units of analysis can become a default stereotyping practice when used for explanatory or structuring purposes. Every transfer of information necessarily involves changes. That is the point where translation studies (studying both intra- and interlingual translation) shows an added value for imagological approaches. Journalistic text production is often a form of selecting, deselecting, re-editing and rewriting. These are already filters in an intralingual setting, but even more so when interlingual transfer is added. Every translator, journalist or narrator has to select and de-select when transferring and recontextualising information, including information about national and cultural images. This gatekeeping function inevitably generates interesting material for an imagological approach.

\footnotetext{
42 Leerssen (2016), p. $28 \mathrm{f}$.

43 Leerssen (2016), p. 28 f.

44 See van Doorslaer (2017), p. $220 f$.
} 


\section{Bibliography}

Belam, Martin (2008). “Achtung! Surrender" from The Mirror - Get your Euro 96 newspaper xenophobia here'. http://www.currybet.net/cbet_blog/2008/o2/achtung-surb render-from-the-mir.php [accessed 24.08.2018].

Billig, Michael (1995). Banal Nationalism (London: Sage).

Caimotto, M. Cristina (2015). 'Images of turmoil. Italy portrayed in Britain and re-portrayed in Italy', in Luc van Doorslaer, Peter Flynn, Joep Leerssen (eds), Interconnecting Translation Studies and Imagology (Amsterdam, Philadelphia: Benjamins), pp. 239-256.

Coenen, Lily (2013). The Image of Spain in Dutch Travel Writing (1860-1960). (Ph.D. Thesis: University of Amsterdam).

Davier, Lucile, Christina Schäffner, Luc van Doorslaer (2018). 'The Methodological Remainder in News Translation Research. Outlining the Background', Across Languages and Cultures, 19.2, pp. 55-64.

D'hulst, Lieven (2008). 'Translation and Its Role in European Literatures. Some Questions and Answers', in Nele Bemong, Mirjam Truwant, Pieter Vermeulen (eds), Re-Thinking Europe. Literature and (Trans)National Identity (Amsterdam, New York: Rodopi), pp. 81-91.

Filmer, Denise (2015). 'Images of Italy. The Words Berlusconi never (officially) said', in Luc van Doorslaer, Peter Flynn, Joep Leerssen (eds), Interconnecting Translation Studies and Imagology (Amsterdam, Philadelphia: Benjamins), pp. 257-276.

Fowler, Corinne (2007). Chasing Tales. Travel Writing, Journalism and the History of British Ideas about Afghanistan (Amsterdam, New York: Rodopi).

Göttlich, Udo (2007). 'Mass Media', in Manfred Beller, Joep Leerssen (eds), Imagology. The cultural construction and literary representation of national characters (Amsterdam, New York: Rodopi), pp. 354-357.

Grix, Jonathan, Chantal Lacroix (2006). 'Constructing Germany's Image in the British Press. An Empirical Analysis of Stereotypical Reporting on Germany', Journal of Contemporary European Studies, 14.3, pp. 373-392.

$\mathrm{Hu}$, Dexiang (2015). 'Translation into Other Languages as a Cultural Disseminator in China', Translation Review, 91, pp. 54-61.

Jakobson, Roman (1959). 'On linguistic aspects of translation', in Reuben Arthur Brower (ed.), On Translation (Cambridge: Harvard University Press), pp. 144-151.

Keller, Thomas (2007). 'Mediator', in Manfred Beller, Joep Leerssen (eds), Imagology. The cultural construction and literary representation of national characters (Amsterdam, New York: Rodopi), pp. 357-359.

Lasorsa, Dominic, Jia Dai (2007). 'When News Reporters Deceive. The Production of Stereotypes', Journalism \& Mass Communication Quarterly, 84.2, pp. 281-298.

Le, Elisabeth (2006). The Spiral of 'Anti-Other Rhetoric'. Discourses of Identity and the International Media Echo (Amsterdam, Philadelphia: Benjamins). 
Leerssen, Joep (2007). 'Imagology: History and Method', in Manfred Beller, Joep Leerssen (eds), Imagology. The cultural construction and literary representation of national characters (Amsterdam, New York: Rodopi), pp. 17-32.

Leerssen, Joep (2011). Spiegelpaleis Europa (Nijmegen: Vantilt).

Leerssen, Joep (2016). 'Imagology. On Using Ethnicity to Make Sense of the World', Iberic@l. Revue d'études ibériques et ibéro-américaines, 10, pp.13-31.

Leerssen, Joep (s.d.). 'A Summary of Imagological Theory'. http://imagologica.eu/theoS reticalsummary [accessed 14.08.2018].

Stetting, Karen (1989). 'Transediting. A new term for coping with the grey area between editing and translating', in Graham Caie et al. (eds), Proceedings from the Fourth Nordic Conference for English Studies (Copenhagen: University of Copenhagen), pp. 371-382.

Valdeón, Roberto A. (2013). 'Doña Marina/La Malinche. A historiographical approach to the interpreter/traitor', Target, 25.2, pp. 157-179.

Valdeón, Roberto A. (2015a). 'Fifteen years of journalistic translation research and more', Perspectives, 23.4, pp. 634-662.

Valdeón, Roberto A. (2015b). 'The construction of national images through news translation. Self-framing in El Pais English Edition', in Luc van Doorslaer, Peter Flynn, Joep Leerssen (eds) (2015). Interconnecting Translation Studies and Imagology (Amsterdam, Philadelphia: Benjamins), pp. 219-238.

Van Bever, Maarten (2011). Nationale beeldvorming in de sportjournalistiek. (MA Thesis: Lessius Antwerp).

Van Doorslaer, Luc (2010). 'The Double Extension of Translation in the Journalistic Field', Across Languages and Cultures, 11.2, pp. 175-188.

Van Doorslaer, Luc (2012). 'Translating, Narrating and Constructing Images in Journalism. With a Test Case on Representation in Flemish TV News', Meta. Translators' Journal, 57.4, pp. 1046-1059.

Van Doorslaer, Luc (2017). 'The Relative Need for Comparative Translation Studies', Translation and Interpreting Studies, 12.2, pp. 213-23o.

Van Doorslaer, Luc (2018). 'Bound to Expand. The Paradigm of Change in Translation Studies', in Helle V. Dam, Matilde Nisbeth Brøgger, Karen Korning Zethsen (eds), Moving Boundaries in Translation Studies (London, New York: Routledge), pp. 220-23o.

Van Doorslaer, Luc, Peter Flynn, Joep Leerssen (eds) (2015). Interconnecting Translation Studies and Imagology (Amsterdam, Philadelphia: Benjamins).

Zacharasiewicz, Waldemar (2009). 'The Theory of Climate and the North in Anglophone Literatures', in Sverrir Jakobsson (ed.), Images of the North: Histories - Identities - Ideas (Amsterdam, New York: Rodopi), pp. 25-49.

Zacharasiewicz, Waldemar (2010). Imagology Revisited (Amsterdam, New York: Rodopi). 


\title{
The Image of Spain in the Eyes of Austrian, Flemish, French, Italian, Polish and Bulgarian Facebook Users
}

\author{
Text-Linguistic Opinion-Mining for Detecting and Analysing \\ National Stereotypes
}

Raúl Sánchez Prieto

\begin{abstract}
The empirical analysis of Social Web comments and conversations as mostly intranational interactions prove to be a valuable tool for understanding how stereotypes on European nations are build up and spread. This contribution provides a working tool for evaluating battered national brands during the Eurozone crisis from a linguistic point of view. A text linguistic methodology based on pragmatics, particularly on text functions and text actions, is being proposed and used. It aims at revealing the purpose and text features of the text functions found in Facebook conversations about Spain. The corpus comprises online conversations posted on newspaper pages of two 'Northern European' countries that are not being affected by the crisis (Austria and Belgium), two 'Southern European' ones (Italy and France) and two 'Eastern European' countries that are not part of the Eurozone (Bulgaria and Poland).
\end{abstract} Linguistics: An Unusual but Useful Connection

In the Humanities, the study of national stereotyping and othering patterns can be approached from different perspectives. In this contribution, I would like to present a specific one rooted mainly in text linguistics and pragmatics. The text linguistic, pragmatic and media linguistic approach presented here is intended to be a useful, practical and straightforward method for the empirical analysis of national stereotyping. In this respect, this paper's main goal is to provide a working tool for evaluating national stereotypes on social media. Although the practicality of the proposed approach will be tested in a corpus-based study of Northern, Southern and Eastern European Facebook conversations about Spain, it could also be applied to the study of other European

(C) RAÚl SÁNCHEZ PRIETO, 2021 | DOI:10.1163/9789004436107_013

This is an open access chapter distributed under the terms of the CC BY-NC-ND 4.0 license. 
ethnotypes; for example, the characterisation of the Germans in the French press or of the Polish in Austrian internet forums.

In today's globalised world of competing economies, national stereotypes can be a serious hindrance to companies and corporations perceived to be part of a specific nation. As Laamiri and Ouasti tellingly put it, "l'image de l'Autre est construite à travers un discours où le stéréotype règne en maître glorieux"; national stereotypes are very hard to erase from a given society and need to be actively opposed.

This is one of the most important reasons countries engage in nation branding. In the case of Southern European countries experiencing economic difficulties, the main objectives pursued by their nation branding strategies clearly involve "helping restore international credibility and investor confidence" and "reverse international ratings downgrades" by fighting negative ethnotypes with positive nation brand advertising. ${ }^{2}$ It therefore seems obvious that the cultural dimension of national stereotyping and the economic aspects of a nation brand are closely related.

Most studies on nation branding are conceptual, with empirical research being very limited. ${ }^{3}$ When empirical research is conducted, it is based on sociological description models, and takes the form of surveys, questionnaires or interviews on a given country's reputation. A good example is the Pew Research Center report on the reputation of European countries at the peak of the euro crisis. ${ }^{4}$ In the particular case of Spain, several reports have been published in recent years by the Observatory on the Image of Spain, a working group established within the Spanish think tank Elcano Royal Institute. In this regard, the regular reports Barómetro de la Imagen de España, published once a year since 2012, are particularly relevant. ${ }^{5}$ This sociological approach can also be observed in an increasing number of mostly short studies concerned with the perception of a nation brand in the digital world. ${ }^{6}$ It seems that social media research is being incorporated into this sociological approach to nation branding and national stereotyping.

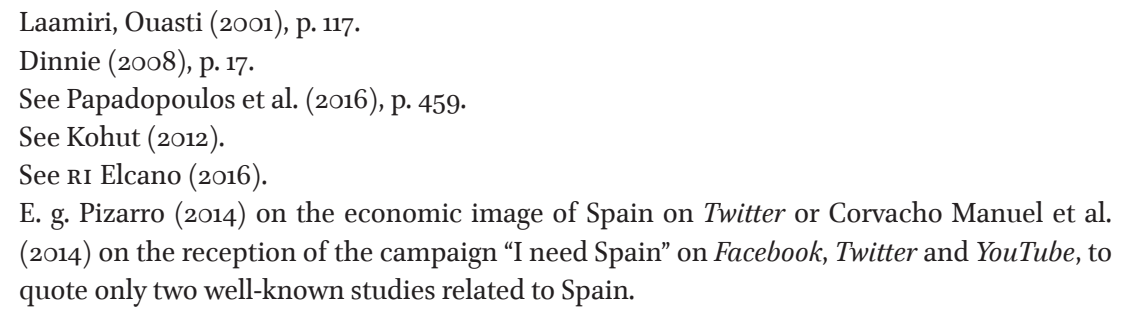


Linguistic studies on national stereotypes are not very common, ${ }^{7}$ but despite this we can distinguish several research streams. ${ }^{8}$ In this respect, most of the linguistic work has been conducted within the framework of two disciplines, Semantics and Critical Discourse Analysis. Ossenberg and Baur provide an insightful review of the most relevant literature on semantic and lexicographic stereotype research. ${ }^{9}$ Critical Discourse Analysis has produced very important work in this respect, particularly (but not only) following the publication of Prejudice in Discourse by Van Dijk (1984). In more recent times, the Vienna School of Critical Discourse Analysis developed by Ruth Wodak has been concerned with identity construction and stereotyped images of the Other. As for text and media linguistics, despite the theoretical and empirical work by, for example, Dąbrowska, ${ }^{10}$ Pümpel-Mader, ${ }^{11}$ and others, text linguistic research on national stereotyping has been very scarce to date.

Against this background, it is no wonder that social media have been neglected in text linguistic research concerning national stereotyping. This is not the case with other linguistic subfields, such as Critical Discourse Analysis, where there is an ongoing discussion on how to approach social media data. ${ }^{12}$

However, as Facebook, Twitter and other social media sites are the new "digital public sphere", ${ }^{13}$ the empirical analysis of social media comments and conversations as mostly intranational textual interactions could be vital for understanding how stereotypes on any particular European nation are built up and spread. Today, the perception of the other is shaped by the media only to a certain extent. Text linguists studying national stereotyping also need to consider online comments: internet users increasingly form their opinions about other nations by reading and examining online content posted by other users, some of whom are veritable opinion-makers.

In the end, therefore, social media conversations about crisis nations may prove essential to the empirical study of national stereotyping. These nations should be aware of their image at a microscale, not least for improving and adapting their nation branding strategies.

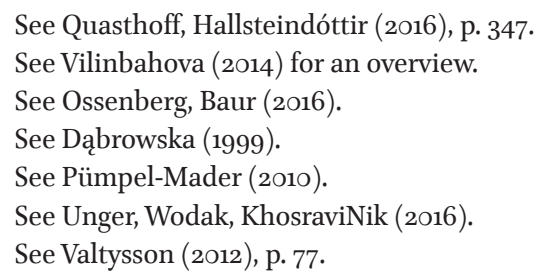




\section{An Empirical Approach to Text Linguistic Opinion Mining for Detecting and Analysing National Stereotypes}

The proposed approach builds on previous research on the communicative macrostructure, particularly on text actions. The description of the actions displayed in online conversations about a given nation will not simply reveal the textual intentions of the commenting user. Far more interesting in our case will be to ascertain which topics related to a given nation they comment on, and how the users elaborate on these topics and characterise this nation. This approach, which is a purely text linguistic one, will be adapted to incorporate polarity in the way this concept is understood in sentiment analysis research. An exploration of the collocational behaviour of terms that refer directly to the nation brand in the text actions will complete the analysis.

\subsection{Text Actions and Sentiment Analysis}

In line with Rothkegel, ${ }^{14}$ I consider text actions (or text acts) to be the main structuring element in texts. Rothkegel's theory of text action, which is based on previous work by Rehbein, Gülich, Brandt/Rosengren and other authors, ${ }^{15}$ describes the interaction between writer and reader as a thematic means of structuring a text. Rothkegel's text actions are obviously modelled on Speech Act Theory.

However, contrary to speech acts and similarly to Geis' Dynamic Speech Act Theory, text acts cannot be associated "with the use of particular linguistic constructions". ${ }^{16}$ They should instead be understood as communicative actions that constitute the text's thematic structure. ${ }^{17}$

Of the different theoretical and practical approaches proposed for text acts, ${ }^{18}$ Von der Lage-Müller's "Handlungsmodell" may be the most suitable one for detecting and categorising text actions related to national stereotyping. ${ }^{19}$ This eminently descriptive model will be adapted here to suit our practical needs concerning social media comments about nations.

Three different hierarchical levels of internal organisation for text actions will be identified:

1. The sender's overall textual intent is denoted by the main text action of a given text, which in our case will be 'commenting on Spain (or any other nation)'.

\footnotetext{
14 See Rothkegel (1992), p. 675.

15 See Rehbein (1977); Gülich (1986); Brandt, Rosengren (1992).

16 Geis (1995), p. 12.

17 See Rothkegel (1984), pp. 240-242.

18 See Czachur (2007), pp. 66-77 for an overview.

19 See Von der Lage-Müller (1995), pp. 50-77.
} 
2. The main text action is specified by secondary text actions that articulate the general topic of a textual unit of meaning. For example, 'assessing the working ethos of the Spanish' could be a secondary text action to the main one 'commenting on Spain'.

3. Every secondary text action is effectively realised by an additional third level of text actions, which will be called 'partial secondary text actions'. Continuing with our example on assessing the working ethos of the Spanish, an Austrian Facebook user could, for example, describe the Spanish as being either hard-working or lazy.

Similar approaches based on Von der Lage-Müller have been employed in recent studies on text linguistics, ${ }^{20}$ but no serious attempt has so far been made to link text actions with sentiment analysis.

Sentiment analysis can be broadly defined as the "task of identifying positive or negative opinions, emotions and evaluations". ${ }^{21}$ Its main purpose is "to determine the contextual polarity of a given sentiment". 22

While computational linguistics in its attempt to automatically determine the sentiment contained in a text has done most of the research in this respect, ${ }^{23}$ sentiment analysis can also be applied to other linguistic subfields. In fact, "polarity" is a common concept in imagology and contrastive literature. ${ }^{24}$

Sentiment analysis will be used here to determine the polarity of secondary text actions, which will be broken down into positive and negative partial ones. This method will allow us firstly to determine the national stereotypes social media users comment on, and, secondly, to establish the polarity of those comments. Thus, in this paper national stereotypes will be detected and analysed in conjunction with the text actions they shape and their polarity.

In the particular case of Spain, the Sixth Report on the Image of Spain by the Royal Elcano Institute provides a useful list of national stereotypes, ${ }^{25}$ which can be readily adapted to our needs. Based on this list, 14 secondary text actions will be identified for our search. Four of them evaluate Spanish society, describing Spanish society and assessing the Spanish in terms of trustworthiness, amicability and tolerance. Another four are related to the Spanish economy,

\footnotetext{
20 See, for example Schröder (2003); Janich (2005); Golonka (2009); Ortner (2014); Sánchez Prieto (2017).

$21 \quad$ Stock, Stock (2013), p. 435.

22 Hollander et al. (2016), p. 8.

23 See Taboada (2016) for an overview.

24 For example Leerssen (2007), p. 344.

25 RI Elcano (2016), p. 29.
} 
assessing the state of the Spanish economy, commenting on corruption, and assessing the working ethos of the Spanish and the affluence and material prosperity in Spain. Three more text actions assess Spanish politics, describing the Spanish political system and its political parties, commenting on regional nationalism, and another three are linked to other topics such as commenting on Spanish tourist destinations, Spanish culture, and other topics.

Since computational linguistics has been developing analytical tools for natural language processing for some time now, I was hoping to find a feasible method for automatically recognising and classifying text acts. A computer linguist carried out an evaluation of the performance of some of the existing speech act classifiers, respectively feeding the corresponding tools with one hundred randomly extracted French corpus comments on Spain. The same comments were also manually broken down into text actions. The accuracy obtained with these computational linguistic tools (Maximum Entropy Model, Support Vector Machines and Nä̈ve Bayes classifiers) never exceeded 6o\%, and was far below the accuracy figures reported by the authors proposing or exploring the given tools. The accuracy of sentiment analysis tools such as SentiWordNet and Taboada's Semantic Orientation Calculator was also considered insufficient for our descriptive needs, ${ }^{26}$ and they were hence discarded.

These disappointing results are consistent and may be due to the fact that the applicability of these tools is limited to the subject domains they were designed for. ${ }^{27}$ Besides, there is not always a clear relation between speech or text act and their morphosyntactic and semantic surface.

The lack of a suitable speech or text act classifier forced us to adopt a partly manual, partly automatic, procedure. Each corpus was automatically broken down into units of meaning by adding sentence boundaries to the compiled corpus with the help of Python Natural Language Toolkit. The automatic segmentation was then manually revised and corrected. The units of meaning were then categorised into one of the secondary text actions considered, and their polarity determined.

\subsection{Collocational Behaviour of Key Words Referring Directly to the Nation Brand}

Studying the collocational behaviour of key words that refer directly to the nation brand could also shed some light on the use of national stereotypes on

\footnotetext{
26 See Taboada (2011).

27 See Ortiz, Hernández (2013), p. 98.
} 
social media. Collocations are understood here as the recurrent co-occurrence of words; that is, the "tendency for words to occur together repeatedly". ${ }^{28}$ The study of collocation patterns is widely used in Critical Discourse Analysis, ${ }^{29}$ and may help reveal stereotyping schemes in a text linguistic study such as ours.

However, as large bodies of text are generally needed to obtain significant results, the study of collocational patterns may not be relevant for us.

\section{Spain in the Eyes of Northern, Southern and Eastern European Facebook Users}

\subsection{Corpus Description}

The practicality of the proposed analytical method has been tested in a corpus-based study of Facebook conversations about Spain. Facebook is by far the most popular social media platform, and the third most visited site on the internet. ${ }^{30}$ It is thus an ideal platform to extract information about what European internet users think about a given nation. Since reading news items on Spain clearly prompts people to comment on this nation and its citizens, the compiled corpus comprises Facebook conversations posted on the corresponding pages of different newspapers across Europe. I searched the Facebook page of each newspaper for stories containing the terms "Spain" and "Spanish" in the respective language over the period June to December 2016 (six months). Sports and show business news were not considered. All the comments in conversation threads in which Spain was their main topic were extracted. In other words, in order to meet the criteria for inclusion in the corpus, the comments had to appear in Spain-related threads published beneath Facebook posts about Spain.

For each country, one right- and one left-leaning newspaper with the highest circulation in each case were selected. This figure was provided by the national audit bureau of circulation: the Österreichische Auflagenkontrolle in Austria, the Centrum voor Informatie over de Media in Belgium, the Alliance pour les Chiffres de la Presse et des Médias in France, the Federazione Italiana Editori Giornali in Italy, and the Zwiazek Kontroli Dystrybucji Prasy in Poland. The Bulgarian figures were provided by the National Statistical Institute.

\footnotetext{
28 Saeed (2009), p. 6 o.

29 See Fairclough (2003), p. 131.

30 See http://www.alexa.com/topsites [accessed 20.02.2017].
} 
The selected newspapers are as follows:

- For Austria: the centre-right Die Presse and the centre-left weekly Der Standard.

- For Flanders: the centrist De Standaard and the centre-left De Morgen.

- For France: the centre-right Le Figaro and the centre-left Le Monde.

- For Italy: the centre-right Il Corriere della Sera and centre-left La Repubblica.

- For Poland: the centre-right Rzeczpospolita (the largest daily in terms of circulation, Gazeta Wyborcza, had just two news items on Spain and very few comments) and the left-leaning weekly Polytika (there are no relevant centre-left or left daily newspapers in Poland).

- For Bulgaria: the centre-right weekly Kapital and the centre-left daily Trud. Like all the other Bulgarian dailies, Trud is a hybrid tabloid, so the Bulgarian subcorpus is not fully comparable with the other ones.

This constitutes an appropriate selection of relevant newspapers from two Northern European countries (Flanders and Austria), two Southern European ones (Italy and France), and two Eastern European countries outside the Eurozone (Poland and Bulgaria).

The number of tokens and total units of meaning in each subcorpus is stated in Table 11.1. The units of meaning coincide with the text actions. Despite the design of the corpus, it is striking that not even half the text actions refer to Spain.

TABLE 11.1 Corpus description

\begin{tabular}{lrcc}
\hline Country & Tokens & $\begin{array}{c}\text { Units of } \\
\text { meaning (total) }\end{array}$ & $\begin{array}{c}\text { Units of meaning } \\
\text { referring to Spain }\end{array}$ \\
\hline Austria & 5948 & 398 & $140(35.2 \%)$ \\
Flanders & 4274 & 297 & $124(41.8 \%)$ \\
France & 29671 & 1393 & $571(41 \%)$ \\
Italy & 28672 & 1596 & $803(50.3 \%)$ \\
Poland & 1918 & 114 & $83(72.8 \%)$ \\
Bulgaria & 92 & 8 & $8(100 \%)$ \\
Total & 70575 & 3806 & $\mathbf{1 7 2 9}(\mathbf{4 5 . 4} \%)$ \\
\hline
\end{tabular}

\subsection{Text Actions in the Corpus: Results}

The evaluation of the six sets of corpus data according to this description model sheds interesting light on the nature of the text actions referring to 
TABLE 11.2 Secondary text actions (STAs) assessing Spain in Northern, Southern and Eastern European comments

\begin{tabular}{|c|c|c|c|c|c|c|}
\hline & Austrian & Flemish & French & Italian & Polish & Bulgarian \\
\hline $\begin{array}{l}\text { STAs describing } \\
\text { Spanish society }\end{array}$ & $\begin{array}{c}7,9 \% \\
(\mathrm{n}=11)\end{array}$ & $\begin{array}{l}6.5 \% \\
(\mathrm{n}=8)\end{array}$ & $\begin{array}{c}13.2 \% \\
(\mathrm{n}=77)\end{array}$ & $\begin{array}{c}13.1 \% \\
(n=105)\end{array}$ & $\begin{array}{l}4.8 \% \\
(\mathrm{n}=4)\end{array}$ & ○\% \\
\hline $\begin{array}{l}\text { STAs assessing the } \\
\text { Spanish economy }\end{array}$ & $\begin{array}{c}27.1 \% \\
(n=38)\end{array}$ & $\begin{array}{l}33 \cdot 9 \% \\
(n=42)\end{array}$ & $\begin{array}{c}24.7 \% \\
(n=142)\end{array}$ & $\begin{array}{c}22.2 \% \\
(\mathrm{n}=179)\end{array}$ & ०\% & ०\% \\
\hline $\begin{array}{l}\text { STAs assessing } \\
\text { Spanish politics }\end{array}$ & $\begin{array}{c}44 \cdot 3 \% \\
(n=62)\end{array}$ & $\begin{array}{c}43 \cdot 5 \% \\
(n=54)\end{array}$ & $\begin{array}{c}54.8 \% \\
(n=310)\end{array}$ & $\begin{array}{c}29.2 \% \\
(n=234)\end{array}$ & $\begin{array}{c}41 \% \\
(n=34)\end{array}$ & $\begin{array}{c}88 \% \\
(n=7)\end{array}$ \\
\hline $\begin{array}{l}\text { STAs on other topics } \\
\text { related to Spain }\end{array}$ & $\begin{array}{c}20.7 \% \\
(\mathrm{n}=29)\end{array}$ & $\begin{array}{c}16.1 \% \\
(n=20)\end{array}$ & $\begin{array}{c}7 \cdot 3 \% \\
(\mathrm{n}=42)\end{array}$ & $\begin{array}{c}35 \cdot 5 \% \\
(n=285)\end{array}$ & $\begin{array}{c}54.2 \% \\
(n=45)\end{array}$ & $\begin{array}{c}12 \% \\
(\mathrm{n}=1)\end{array}$ \\
\hline Total & $\begin{array}{c}100 \% \\
(n=140)\end{array}$ & $\begin{array}{c}100 \% \\
(n=124)\end{array}$ & $\begin{array}{c}100 \% \\
(n=571)\end{array}$ & $\begin{array}{c}100 \% \\
(\mathrm{n}=803)\end{array}$ & $\begin{array}{c}100 \% \\
(\mathrm{n}=83)\end{array}$ & $\begin{array}{l}100 \% \\
(\mathrm{n}=8)\end{array}$ \\
\hline
\end{tabular}

Spain. Politics seems to be the most relevant topic for Austrian, Flemish, French and Bulgarian Facebook users involved in conversations about Spain (see Table 11.2). In contrast, secondary text actions (STAs) "describing other topics related to Spain" in the Italian and Polish subcorpora record the highest percentage. Tellingly, only Western Europeans are apparently interested in assessing the Spanish economy: $22-34 \%$ of all Spain-related sTAs in the Austrian, Flemish, French and Italian subcorpora do so. As these results are only partially influenced by the range of news topics and news items posted by each newspaper on Facebook, these findings are very striking. The Spanish economic crisis does not appear to be a hot topic in Poland or Bulgaria, at least not on Facebook.

\subsubsection{Assessing Spanish Society}

The number of occurrences or number of secondary text actions assessing Spanish society is very low or non-existent in the Eastern European corpora and low in the Northern European ones. The results that can be extracted from the corpus (Table 11.3) are therefore only truly relevant in the case of the Italian and French datasets.

In the Austrian and Flemish corpora, Spanish society is described as being more traditional than modern: $77 \cdot 7 \%$ of all Austrian partial secondary text actions (PSTAS) and 100\% of all Flemish ones assessing Spanish society describe Spain as a traditional country. The French seem to have a completely 
TABLE 11.3 STAs and PSTAs assessing Spanish society in Northern, Southern and Eastern European comments about Spain

\begin{tabular}{|c|c|c|c|c|c|c|}
\hline & Austrian & Flemish & French & Italian & Polish & Bulgarian \\
\hline $\begin{array}{l}\text { STAs describing } \\
\text { Spanish } \\
\text { society }\end{array}$ & $\begin{array}{l}81,8 \% \\
(\mathrm{n}=9)\end{array}$ & $\begin{array}{c}50 \% \\
(n=4)\end{array}$ & $\begin{array}{c}26 \% \\
(n=20)\end{array}$ & $\begin{array}{c}22,8 \% \\
(n=24)\end{array}$ & o & o \\
\hline $\begin{array}{l}\text { characterising } \\
\text { Spain as a } \\
\text { modern country }\end{array}$ & o & o & $\begin{array}{c}50 \% \\
(n=10)\end{array}$ & $\begin{array}{l}45,8 \% \\
(n=11)\end{array}$ & & \\
\hline $\begin{array}{l}\text { characterising } \\
\text { Spain as a } \\
\text { traditional } \\
\text { country }\end{array}$ & $\begin{array}{l}77 \cdot 7 \% \\
(\mathrm{n}=7)\end{array}$ & $\begin{array}{c}100 \% \\
(n=4)\end{array}$ & $\begin{array}{c}35 \% \\
(n=7)\end{array}$ & $\begin{array}{c}45,8 \% \\
(n=11)\end{array}$ & & \\
\hline neutral & $\begin{array}{l}22.3 \% \\
(\mathrm{n}=2)\end{array}$ & o & $\begin{array}{c}15 \% \\
(n=3)\end{array}$ & $\begin{array}{c}8,4 \% \\
(n=2)\end{array}$ & & \\
\hline $\begin{array}{l}\text { STAs assessing } \\
\text { the Spanish on } \\
\text { trustworthiness }\end{array}$ & $\begin{array}{l}18,2 \% \\
(n=2)\end{array}$ & $\begin{array}{c}50 \% \\
(n=4)\end{array}$ & $\begin{array}{c}28,6 \% \\
(n=22)\end{array}$ & $\begin{array}{c}64,8 \% \\
(n=68)\end{array}$ & $\begin{array}{l}100 \% \\
(n=4)\end{array}$ & o \\
\hline $\begin{array}{l}\text { stating that the } \\
\text { Spanish are } \\
\text { trustworthy }\end{array}$ & o & o & $\begin{array}{c}45,4 \% \\
(n=10)\end{array}$ & $\begin{array}{c}7,4 \% \\
(n=5)\end{array}$ & $\begin{array}{c}75 \% \\
(\mathrm{n}=3)\end{array}$ & \\
\hline $\begin{array}{l}\text { stating that the } \\
\text { Spanish are not } \\
\text { to be trusted }\end{array}$ & $\begin{array}{c}100 \% \\
(n=2)\end{array}$ & $\begin{array}{c}100 \% \\
(n=4)\end{array}$ & $\begin{array}{c}54,6 \% \\
(n=12)\end{array}$ & $\begin{array}{c}70,6 \% \\
(n=48)\end{array}$ & $\begin{array}{c}25 \% \\
(\mathrm{n}=1)\end{array}$ & \\
\hline neutral & o & o & o & $\begin{array}{c}22 \% \\
(n=15)\end{array}$ & o & \\
\hline $\begin{array}{l}\text { STAs assessing } \\
\text { the Spanish on } \\
\text { amicability }\end{array}$ & o & o & $\begin{array}{c}28,6 \% \\
(n=22)\end{array}$ & $\begin{array}{l}10,5 \% \\
(\mathrm{n}=11)\end{array}$ & o & $\mathrm{O}$ \\
\hline $\begin{array}{l}\text { expressing that } \\
\text { the Spanish are } \\
\text { friendly }\end{array}$ & & & $\begin{array}{l}68,2 \% \\
(n=15)\end{array}$ & $\begin{array}{l}45,4 \% \\
(n=5)\end{array}$ & & \\
\hline $\begin{array}{l}\text { describing the } \\
\text { Spanish as } \\
\text { unfriendly }\end{array}$ & & & $\begin{array}{l}18,2 \% \\
(n=4)\end{array}$ & $\begin{array}{c}54,6 \% \\
(\mathrm{n}=6)\end{array}$ & & \\
\hline
\end{tabular}


TABLE 11.3 STAs and PSTAs assessing Spanish society in Northern, Southern and Eastern European comments about Spain (cont.)

\begin{tabular}{|c|c|c|c|c|c|c|}
\hline & Austrian & Flemish & French & Italian & Polish & Bulgarian \\
\hline neutral & & & $\begin{array}{l}13,6 \% \\
(\mathrm{n}=3)\end{array}$ & $\mathrm{O}$ & & $\mathrm{O}$ \\
\hline $\begin{array}{l}\text { STAs assessing } \\
\text { the Spanish on } \\
\text { tolerance }\end{array}$ & O & o & $\begin{array}{c}16,8 \% \\
(n=13)\end{array}$ & $\begin{array}{c}1,9 \% \\
(n=2)\end{array}$ & o & o \\
\hline $\begin{array}{l}\text { describing } \\
\text { Spanish society } \\
\text { as tolerant }\end{array}$ & & & $\begin{array}{c}76,9 \% \\
(n=10)\end{array}$ & $\begin{array}{c}5 \circ \% \\
(n=1)\end{array}$ & & \\
\hline $\begin{array}{l}\text { describing } \\
\text { Spanish society } \\
\text { as intolerant }\end{array}$ & & & $\begin{array}{c}23,1 \% \\
(n=3)\end{array}$ & $\begin{array}{c}50 \% \\
(n=1)\end{array}$ & & \\
\hline neutral & & & $\mathrm{O}$ & o & & \\
\hline Total & $\begin{array}{c}100 \% \\
(\mathrm{n}=11, \\
7 \cdot 9 \% \text { from } \\
\text { total STAs) }\end{array}$ & $\begin{array}{c}100 \% \\
(\mathrm{n}=8 \\
6.5 \% \\
\text { from total } \\
\text { STAs) }\end{array}$ & $\begin{array}{c}100 \% \\
(\mathrm{n}=77, \\
13.2 \% \text { from } \\
\text { total STAs })\end{array}$ & $\begin{array}{c}100 \% \\
(\mathrm{n}=105, \\
13.1 \% \text { from } \\
\text { total STAs) }\end{array}$ & $\begin{array}{c}100 \% \\
(\mathrm{n}=4, \\
4.8 \% \text { from } \\
\text { total STAs) }\end{array}$ & $\begin{array}{l}100 \% \\
(\mathrm{n}=0)\end{array}$ \\
\hline
\end{tabular}

different opinion in this respect: $50 \%$ of the partial secondary text actions have a positive polarity (that is, Spain is a modern country), while only $35 \%$ have a negative polarity. The Italians seem to be divided on this matter. The following Austrian example, which condemns bullfighting, is a telling example:

(1) "Spanien sollte lieber die tierquäler bestrafen, die stierkämpfe abschaffen und die toten windhunde von den bäumen schneiden, auf denen die spanischen jäger sie am saisonende aufknüpfen" (A-STANDARD $\left.5^{2}\right)^{31}$

The secondary text action "assessing the Spanish on trustworthiness" is designed to address the typical stereotype of the untrustworthiness and

$31 \quad$ Examples are referenced with country abbreviation-name of the newspaper-Facebook comment number in each corpus. 
unreliability of the Spanish. This national stereotype seems to be deeply ingrained in Western Europe, particularly in Austria and Flanders, but also in France. At the other extreme, the Polish are the most positive ones about the Spanish. The Italian data should be viewed with caution, as three-quarters of these negative text actions are related to a single news item on a Spanish court decision finding a bus driver not guilty of negligent homicide after a coach crash in Spain involving Italian students. In the next example, a Facebook user is implicitly describing Spanish justice as untrustworthy:

(2) "La giustizia spagnola, peggiore della.nostra, se possibile [...]" (I-CORRIERE 42)

Only the French and Italians assess the Spanish on friendliness and tolerance. In the French corpus, Spain is mostly seen as a friendly and tolerant nation, and in some cases is described as more so than France, as in these two units of meaning:

(3) “Je trouve que l'Espagne est un pays beaucoup plus tolérant avec l'homosexualité que la France. J'ai vécu à Madrid et personne ne m’a jamais insulté pour embrasser un garçon dans le métro où me balader main dans la main avec lui dans la rue de n'importe quel quartier. JAMAIs." (F-LE MONDE 119)

In contrast, the percentage of partial secondary text actions in the Italian corpus describing the Spanish as unfriendly and not to be trusted amounts to nearly $55 \%$ and $71 \%$, respectively.

\subsubsection{Assessing the Spanish Economy}

About a quarter of all Western European text actions assess the Spanish economy. As the empirical data from Table 11.4 suggest, Spain is mostly perceived as a country in economic regression.

The secondary text action "assessing the shape of the Spanish economy" is the most important one in terms of occurrences in all relevant data sets. In their corpora, the Austrians, the Flemish and the French overwhelmingly describe the Spanish economy as particularly weak, as in (4):

(4) "Ein Land, in dem Arbeitslosigkeit, Schulden und sinkende Löhne einen Linksruck bringt [...]” (A-PRESSE 46)

In the Italian corpus, a sizable percentage of partial text actions surprisingly describe the economic situation as strong $(26 \%)$, or neither weak nor strong 
TABLE 11.4 STAs and PSTAs assessing the Spanish economy in Northern, Southern and Eastern European comments about Spain

\begin{tabular}{|c|c|c|c|c|c|c|}
\hline & Austrian & Flemish & French & Italian & Polish & Bulgarian \\
\hline $\begin{array}{l}\text { STAs assessing the } \\
\text { state of the Spanish } \\
\text { economy }\end{array}$ & $\begin{array}{c}47 \cdot 4 \% \\
(n=18)\end{array}$ & $\begin{array}{c}33 \cdot 3 \% \\
(n=14)\end{array}$ & $\begin{array}{c}55 \% \\
(\mathrm{n}=78)\end{array}$ & $\begin{array}{c}68.8 \% \\
(n=123)\end{array}$ & o & o \\
\hline $\begin{array}{l}\text { describing the } \\
\text { Spanish economy } \\
\text { as strong }\end{array}$ & $\begin{array}{l}5 \cdot 6 \% \\
(\mathrm{n}=1)\end{array}$ & $\mathrm{o}$ & $\begin{array}{l}7 \cdot 7 \% \\
(\mathrm{n}=6)\end{array}$ & $\begin{array}{c}26 \% \\
(\mathrm{n}=32)\end{array}$ & & \\
\hline $\begin{array}{l}\text { describing the } \\
\text { Spanish economy } \\
\text { as weak }\end{array}$ & $\begin{array}{l}94.4 \% \\
(\mathrm{n}=17)\end{array}$ & $\begin{array}{l}85 \cdot 7 \% \\
(n=12)\end{array}$ & $\begin{array}{c}83 \cdot 3 \% \\
(\mathrm{n}=65)\end{array}$ & $\begin{array}{l}58.5 \% \\
(\mathrm{n}=72)\end{array}$ & & \\
\hline neutral & $\mathrm{O}$ & $\begin{array}{l}14 \cdot 3 \% \\
(\mathrm{n}=2)\end{array}$ & $\begin{array}{c}9 \% \\
(\mathrm{n}=7)\end{array}$ & $\begin{array}{c}15 \cdot 5 \% \\
(\mathrm{n}=19)\end{array}$ & & \\
\hline $\begin{array}{l}\text { Assessing the } \\
\text { working ethos of the } \\
\text { Spanish }\end{array}$ & $\begin{array}{l}10.5 \% \\
(\mathrm{n}=4)\end{array}$ & $\begin{array}{l}11.9 \% \\
(\mathrm{n}=5)\end{array}$ & $\begin{array}{l}4.9 \% \\
(\mathrm{n}=7)\end{array}$ & o & o & o \\
\hline $\begin{array}{l}\text { describing the } \\
\text { Spanish as hard- } \\
\text { working }\end{array}$ & $\mathrm{O}$ & $\mathrm{o}$ & $\begin{array}{l}28.6 \% \\
(\mathrm{n}=2)\end{array}$ & & & \\
\hline $\begin{array}{l}\text { describing the } \\
\text { Spanish as lazy }\end{array}$ & $\begin{array}{l}100 \% \\
(n=4)\end{array}$ & $\begin{array}{l}100 \% \\
(\mathrm{n}=5)\end{array}$ & $\begin{array}{l}57.2 \% \\
(\mathrm{n}=4)\end{array}$ & & & \\
\hline neutral & o & o & $\begin{array}{l}14.2 \% \\
(\mathrm{n}=1)\end{array}$ & & & \\
\hline $\begin{array}{l}\text { Commenting on } \\
\text { corruption in Spain }\end{array}$ & $\begin{array}{c}26.3 \% \\
(\mathrm{n}=10)\end{array}$ & $\begin{array}{c}28.6 \% \\
(\mathrm{n}=12)\end{array}$ & $\begin{array}{l}4.2 \% \\
(\mathrm{n}=6)\end{array}$ & $\begin{array}{c}10 \% \\
(n=18)\end{array}$ & o & $\mathrm{o}$ \\
\hline $\begin{array}{l}\text { characterising the } \\
\text { Spanish as honest }\end{array}$ & o & $\begin{array}{l}8.3 \% \\
(n=1)\end{array}$ & $\begin{array}{l}33 \cdot 3 \% \\
(\mathrm{n}=2)\end{array}$ & $\begin{array}{l}33 \cdot 3 \% \\
(\mathrm{n}=6)\end{array}$ & & \\
\hline $\begin{array}{l}\text { characterising the } \\
\text { Spanish as corrupt }\end{array}$ & $\begin{array}{c}8 \circ \% \\
(n=8)\end{array}$ & $\begin{array}{l}83.4 \% \\
(n=10)\end{array}$ & $\begin{array}{l}67 \cdot 7 \% \\
(n=4)\end{array}$ & $\begin{array}{c}67 \cdot 7 \% \\
(\mathrm{n}=12)\end{array}$ & & \\
\hline neutral & $\begin{array}{c}20 \% \\
(\mathrm{n}=2)\end{array}$ & $\begin{array}{l}8.3 \% \\
(n=1)\end{array}$ & o & $\mathrm{o}$ & & \\
\hline $\begin{array}{l}\text { Assessing affluence } \\
\text { and material } \\
\text { prosperity in Spain }\end{array}$ & $\begin{array}{l}15.8 \% \\
(\mathrm{n}=6)\end{array}$ & $\begin{array}{l}26.2 \% \\
(\mathrm{n}=11)\end{array}$ & $\begin{array}{l}35 \cdot 9 \% \\
(\mathrm{n}=51)\end{array}$ & $\begin{array}{c}21.2 \% \\
(\mathrm{n}=38)\end{array}$ & $\mathrm{o}$ & o \\
\hline
\end{tabular}


TABLE 11.4 STAs and PSTAs assessing the Spanish economy in Northern, Southern and Eastern European comments about Spain (cont.)

\section{Austrian Flemish French Italian Polish Bulgarian}

describing Spain

as an affluent

and prosperous

country

describing Spain

as an impover-

ished and

declining country

neutral

Total

$\begin{array}{ccc}27 \cdot 3 & 3.9 \% & 7 \cdot 9 \% \\ (\mathrm{n}=3) & (\mathrm{n}=2) & (\mathrm{n}=3)\end{array}$

$\begin{array}{cccc}83.3 \% & 72.7 \% & 92.2 \% & 92.1 \% \\ (\mathrm{n}=5) & (\mathrm{n}=8) & (\mathrm{n}=47) & (\mathrm{n}=35)\end{array}$

$6.7 \%$

$(\mathrm{n}=1)$

$3.9 \%$

$(\mathrm{n}=2)$

O

$100 \%$

( $\mathrm{n}=38$,

$27.1 \%$

from total

STAs)
$100 \%$

$100 \% \quad 100 \%$

$(\mathrm{n}=42, \quad(\mathrm{n}=142, \quad(\mathrm{n}=179$,

$33.9 \% \quad 24.7 \% \quad 22.2 \%$

from from from all total total STAs)

(neutral, 15.5\%). In most of these units of meaning, the Italian economic situation is compared to the Spanish one, as in (5):

(5) "senza governo crescono del 3,5 \%. noi con il bomba, pdioti alfano e verdini, o.00000000000000 periodico" (I-REPUBBLICA 331)

The working ethos of the Spanish is assessed in the Austrian, Flemish and French corpora. In all three, but especially in the Austrian and Flemish ones, the Spanish are mainly characterised as lazy.

Commenting on corruption in Spain is not as common as expected. When the Austrian, the Flemish, the French and the Italian Facebook users do comment on corruption in the compiled corpus, they consider the Spanish to be corrupt in a clear majority of cases, as in (6):

(6) "Le plus grave c"est que la corruption est completement normalisée dans la société espagnole." (F-LE MONDE 636) 
This stereotype is thus still very much alive. In most of the stas studied, Spain is seen as an impoverished country in decline. This has been the traditional view of Northern and Western Europeans towards Spain for decades, as in the following Flemish example:

(7) "Hij heeft, en nog, de Spanjaarden uitgemolken en de slechte resultaren zijn er, 22,8 \% werklozen, $28,6 \%$ vd bevolking is arm, $50 \%$ vd jongeren hebben geen werk." (BE-DM 4)

However, even Northern European Facebook users recognize that Spain is in the main a developed country, as in the following Flemish comment, where Brussels and Madrid are compared and the Belgian infrastructure deficits are acknowledged:

(8) "Waar wachten jullie nog op, Brussel en de Vlaamse rand, om net als rond Madrid vier concentrische ringwegen aan te leggen!" (BE-STAN 39)

\subsubsection{Assessing Spanish Politics}

Spanish politics is assessed in a high percentage of Western, Southern and Eastern European comments (see Table 11.5 for an overview and below for the discussion). This may be due to the fact that a good deal of Spain-related news posted on Facebook falls into the realm of politics.

Judging from the results, Spain is not considered a particularly stable democracy by the Austrian, the Flemish, the French and the Polish. In contrast, the Italians overwhelmingly state that Spain is a stable democracy.

Most text actions referring to Spanish politics focus on Spanish political parties. The vast majority of Northern and Southern European text actions reveal a negative polarity in this respect. The Austrians and the Flemish seem to be particularly sceptical about Spanish politicians, often even being hostile when they describe them as corrupt and damaging to the Spanish people, as in (9) and (10):

(9)“De man die Spanje kapotbespaarde, wordt nu de premier van een minderheidsregering [...].” (BE-DM 32 )

(10) "Sie [Die Spanier] sind empört über die Günstlingswirtschaft und Korruption in den beiden großen Volksparteien." (A-PRESSE 45)

The Polish and Bulgarians have a much more positive opinion of Spanish politicians. In most cases, this is the result of comparing their own political system 
STA sand PSTAs assessing Spanish politics in Northern, Southern and Eastern European comments about Spain

\section{Austrian Flemish French Italian Polish Bulgarian}

Describing the

Spanish political

system

stating that

Spain is a stable

democracy

commenting

on the lack of

democracy in

Spain

neutral

Describing Spanish

political parties

in a positive

manner

in a negative

manner

neutral

Commenting on

regional nationalism

aligning him

or herself with

Spanish consti-

tutionalism

aligning him

or herself

with regional

nationalism

$\begin{array}{ccccc}8.1 \% & 13 \% & 11.6 \% & 5.2 \% & 11.8 \% \\ (\mathrm{n}=5) & (\mathrm{n}=7) & (\mathrm{n}=36) & (\mathrm{n}=12) & (\mathrm{n}=4)\end{array}$

$\begin{array}{ccccc}40 \% & 28.6 \% & 41.7 \% & 66.7 \% & 25 \% \\ (\mathrm{n}=2) & (\mathrm{n}=2) & (\mathrm{n}=15) & (\mathrm{n}=8) & (\mathrm{n}=1)\end{array}$

$6 \circ \%$

$57.1 \%$

$58.3 \%$

$25 \%$

$75 \%$

$(\mathrm{n}=3)$

$(\mathrm{n}=4)$

$(\mathrm{n}=21)$

$(\mathrm{n}=3)$

$(\mathrm{n}=3)$

o

$14 \cdot 3 \%$
$(\mathrm{n}=1)$

o

$$
\begin{gathered}
8.3 \% \\
(n=1)
\end{gathered}
$$

$\begin{array}{cccccc}80.6 \% & 64.8 \% & 72.3 \% & 88 \% & 17.6 \% & 100 \% \\ (\mathrm{n}=50) & (\mathrm{n}=35) & (\mathrm{n}=22) & (\mathrm{n}=206) & (\mathrm{n}=6) & (\mathrm{n}=7)\end{array}$

$\begin{array}{cccccc}10 \% & 5.7 \% & 18.3 \% & 11.7 \% & 50 \% & 71.4 \% \\ (\mathrm{n}=5) & (\mathrm{n}=2) & (\mathrm{n}=41) & (\mathrm{n}=24) & (\mathrm{n}=3) & (\mathrm{n}=5)\end{array}$

\section{$82 \%$}

$85.7 \%$

$65.2 \%$

$62.1 \%$

$16.6 \%$

$28.6 \%$

$(\mathrm{n}=41)$

$(\mathrm{n}=30)$

$(\mathrm{n}=146)$

$(\mathrm{n}=128)$

$(\mathrm{n}=1)$

$(\mathrm{n}=2)$

$\begin{array}{ccccc}8 \% & 8.6 \% & 16.5 \% & 26.2 \% & 33.4 \% \\ (\mathrm{n}=4) & (\mathrm{n}=3) & (\mathrm{n}=37) & (\mathrm{n}=54) & (\mathrm{n}=2)\end{array}$

$11.3 \%$

$$
22.2
$$

$16.1 \%$

$6.8 \%$

$70.6 \%$

$(\mathrm{n}=7)$

$(\mathrm{n}=12)$

$\left(\mathrm{n}=5^{\circ}\right)$

$(\mathrm{n}=16)$

$(\mathrm{n}=24)$

O 
TABLE 11.5 STA sand PSTAs assessing Spanish politics in Northern, Southern and Eastern European comments about Spain (cont.)

\begin{tabular}{ccccccc}
\hline & Austrian & Flemish & French & Italian & Polish & Bulgarian \\
\hline \multirow{2}{*}{ neutral } & 0 & 0 & $\begin{array}{c}20 \% \\
(\mathrm{n}=10)\end{array}$ & 0 & $\begin{array}{c}16.7 \% \\
(\mathrm{n}=4)\end{array}$ & \\
& & & & & & \\
& & & & & & \\
& $100 \%$ & $100 \%$ & $100 \%(\mathrm{n}$ & $100 \%$ & $100 \%$ & \\
& $(\mathrm{n}=62$, & $(\mathrm{n}=54$, & $=310$, & $(\mathrm{n}=234$, & $(\mathrm{n}=34$, & $100 \%$ \\
& $44.3 \%$ & $43.5 \%$ & $54.8 \%$ & $29.2 \%$ & $41 \%$ & $(\mathrm{n}=7$ \\
& from & from & from all & from all & from all & $88 \%$ from \\
& total & total & STAs $)$ & STAs $)$ & STAs $)$ & all STAs $)$ \\
& STAs $)$ & STAs $)$ & & & & \\
\hline
\end{tabular}

with the Spanish one. A good example may be (11): a Bulgarian internet user thanks the Spanish minister of economic affairs for using plain language to talk about straightforward (economic) facts:

(11) “Най-после, някой да го каже на 'ясен български'?” (BG-KAPITAL 1)

In the Flemish, French, Italian and Polish corpora, a significant number of text actions comment on the Catalan question and on regional nationalism. The French and the Italians seem to align themselves with Spanish constitutionalism rather than with regional nationalism. In contrast, the Flemish (as well as the Austrians) tend to welcome Catalan separatism (see example 12). The Polish react very differently and stress in their comments that they do not understand Catalan separatism, as in (13), where all separatists are labelled "idiots":

(12) “Catalonië onafhankelijk!" (BE-DM 4)

(13) “Debiły! Wszyscy separatyscy są debiłami” (PL- RzECzPospolita 15)

\subsubsection{Assessing the Spanish on Other Topics}

Spain is still seen as an attractive tourist destination. The positive polarity is high in the Austrian, Flemish and Polish text actions. It is, however, mainly negative in the French and Italian corpora. Only the Austrians, the French, the Italians and the Polish assess Spanish culture. The opinions expressed in the 
French and Polish corpora are overwhelmingly positive, whereas in the Italian case they are mainly negative or neutral.

The last secondary text action, "commenting on other topics", is extremely interesting. When commenting on other Spain-related topics, the Flemish and French appear to do so in a mainly positive manner, while the Polish adopt a neutral tone. The results for the Italian corpus are misleading, as over three quarters of the Italian partial secondary text actions are assessments of the Franco period (see Table 11.6 for more details).

TABLE 11.6 STAs and PSTAs assessing the Spanish on other topics in Northern, Southern and Eastern European comments about Spain

\section{Austrian Flemish French Italian Polish Bulgarian}

\begin{tabular}{|c|c|c|c|c|c|c|}
\hline $\begin{array}{l}\text { Commenting on } \\
\text { Spanish tourist } \\
\text { destinations }\end{array}$ & $\begin{array}{c}34.5 \% \\
(\mathrm{n}=10)\end{array}$ & $\begin{array}{c}35 \% \\
(\mathrm{n}=7)\end{array}$ & $\begin{array}{l}16.6 \% \\
(\mathrm{n}=7)\end{array}$ & $\begin{array}{c}8.8 \% \\
(\mathrm{n}=25)\end{array}$ & $\begin{array}{l}15.6 \% \\
(\mathrm{n}=7)\end{array}$ & o \\
\hline $\begin{array}{l}\text { making a positive } \\
\text { comment on a } \\
\text { tourist destination }\end{array}$ & $\begin{array}{c}8 \circ \% \\
(\mathrm{n}=8)\end{array}$ & $\begin{array}{l}42.8 \% \\
(\mathrm{n}=3)\end{array}$ & $\begin{array}{l}28.6 \% \\
(\mathrm{n}=2)\end{array}$ & $\begin{array}{c}36 \% \\
(\mathrm{n}=9)\end{array}$ & $\begin{array}{l}100 \% \\
(\mathrm{n}=7)\end{array}$ & \\
\hline $\begin{array}{l}\text { making a negative } \\
\text { comment on a } \\
\text { tourist destination }\end{array}$ & $\begin{array}{c}20 \% \\
(\mathrm{n}=2)\end{array}$ & $\begin{array}{c}28.6 \\
(\mathrm{n}=2)\end{array}$ & $\begin{array}{l}42.8 \% \\
(\mathrm{n}=3)\end{array}$ & $\begin{array}{c}5^{2 \%} \\
(\mathrm{n}=13)\end{array}$ & o & \\
\hline neutral & o & $\begin{array}{l}28.6 \% \\
(\mathrm{n}=2)\end{array}$ & $\begin{array}{l}28.6 \% \\
(\mathrm{n}=2)\end{array}$ & $\begin{array}{c}12 \% \\
(\mathrm{n}=3)\end{array}$ & $\mathrm{O}$ & \\
\hline $\begin{array}{l}\text { Commenting on } \\
\text { Spanish culture }\end{array}$ & $\begin{array}{l}10.3 \% \\
(\mathrm{n}=3)\end{array}$ & o & $\begin{array}{l}7.2 \% \\
(\mathrm{n}=3)\end{array}$ & $\begin{array}{c}11.2 \% \\
(\mathrm{n}=32)\end{array}$ & $\begin{array}{l}35.6 \% \\
(n=16)\end{array}$ & o \\
\hline $\begin{array}{l}\text { making a positive } \\
\text { comment on } \\
\text { Spanish culture }\end{array}$ & $\begin{array}{l}66.7 \% \\
(\mathrm{n}=2)\end{array}$ & & $\begin{array}{l}100 \% \\
(\mathrm{n}=3)\end{array}$ & $\begin{array}{l}9.4 \% \\
(\mathrm{n}=3)\end{array}$ & $\begin{array}{c}75 \% \\
(\mathrm{n}=12)\end{array}$ & \\
\hline $\begin{array}{l}\text { making a negative } \\
\text { comment on } \\
\text { Spanish culture }\end{array}$ & $\begin{array}{l}33 \cdot 3 \% \\
(\mathrm{n}=1)\end{array}$ & & O & $\begin{array}{l}40.6 \% \\
(n=13)\end{array}$ & $\begin{array}{l}12.5 \% \\
(\mathrm{n}=2)\end{array}$ & \\
\hline neutral & & & o & $\begin{array}{c}50 \% \\
(n=16)\end{array}$ & $\begin{array}{l}12.5 \% \\
(\mathrm{n}=2)\end{array}$ & \\
\hline $\begin{array}{l}\text { Commenting on other } \\
\text { topics }\end{array}$ & $\begin{array}{l}55.2 \% \\
(n=16)\end{array}$ & $\begin{array}{c}65 \% \\
(n=13)\end{array}$ & $\begin{array}{c}76.2 \% \\
(\mathrm{n}= \\
32)\end{array}$ & $\begin{array}{c}8 \circ \% \\
(\mathrm{n}=228)\end{array}$ & $\begin{array}{l}48.8 \% \\
(n=22)\end{array}$ & $\begin{array}{c}12 \% \\
(\mathrm{n}=1)\end{array}$ \\
\hline
\end{tabular}


TABLE 11.6 STAs and PSTAs assessing the Spanish on other topics in Northern, Southern and Eastern European comments about Spain (cont.)

\begin{tabular}{|c|c|c|c|c|c|c|}
\hline & Austrian & Flemish & French & Italian & Polish & Bulgarian \\
\hline $\begin{array}{l}\text { making a positive } \\
\text { comment }\end{array}$ & $\begin{array}{l}43 \cdot 7 \% \\
(\mathrm{n}=7)\end{array}$ & $\begin{array}{l}38.4 \% \\
(\mathrm{n}=5)\end{array}$ & $\begin{array}{l}65.6 \% \\
(n=21)\end{array}$ & $\begin{array}{c}25 \cdot 4 \% \\
\left(\mathrm{n}=5^{8}\right)\end{array}$ & $\begin{array}{c}9 \cdot 1 \\
(\mathrm{n}=2)\end{array}$ & $\mathrm{o}$ \\
\hline $\begin{array}{l}\text { making a negative } \\
\text { comment }\end{array}$ & $\begin{array}{l}43 \cdot 7 \% \\
(\mathrm{n}=7)\end{array}$ & $\begin{array}{l}30.8 \% \\
(n=4)\end{array}$ & $\begin{array}{l}15.6 \% \\
(\mathrm{n}=5)\end{array}$ & $\begin{array}{c}50 \% \\
(n=114)\end{array}$ & $\begin{array}{l}13.6 \% \\
(\mathrm{n}=3)\end{array}$ & $\begin{array}{l}100 \% \\
(\mathrm{n}=1)\end{array}$ \\
\hline neutral & $\begin{array}{l}12.6 \% \\
(\mathrm{n}=2)\end{array}$ & $\begin{array}{c}30.8 \\
(n=4)\end{array}$ & $\begin{array}{l}18.8 \% \\
(\mathrm{n}=6)\end{array}$ & $\begin{array}{c}24.6 \% \\
\left(\mathrm{n}=5^{6}\right)\end{array}$ & $\begin{array}{l}77 \cdot 3 \% \\
(\mathrm{n}=17)\end{array}$ & $\mathrm{O}$ \\
\hline Total & $\begin{array}{c}100 \% \\
(\mathrm{n}=29 \\
20.7 \% \\
\text { from all } \\
\text { STAs })\end{array}$ & $\begin{array}{c}100 \% \\
(\mathrm{n}=20 \\
16.1 \% \\
\text { from all } \\
\text { STAs })\end{array}$ & $\begin{array}{c}7 \cdot 3 \% \\
(\mathrm{n}= \\
42)\end{array}$ & $\begin{array}{c}100 \% \\
(\mathrm{n}=285, \\
35.5 \% \\
\text { from all } \\
\text { STAs) }\end{array}$ & $\begin{array}{c}100 \% \\
54.2 \% \\
(\mathrm{n}=45 \\
54,2 \% \\
\text { from all } \\
\text { STAs) }\end{array}$ & $\begin{array}{c}100 \% \\
(\mathrm{n}=1,12 \% \\
\text { from all } \\
\text { STAs })\end{array}$ \\
\hline
\end{tabular}

\subsection{Collocations in the Corpus: Results}

As expected, the results obtained by exploring the collocational patterns of the corpus comments are neither representative nor relevant. Lexical approaches are thus only of limited applicability if the data set is small. In our case, almost no collocates for the key term "Spain" could be found in the Austrian, Flemish, Polish and Bulgarian data sets. Table 11.7 shows the few collocates found in the French and Italian corpus by counting the co-occurrences with the key term "Spain". The analysis has been carried out with the help of the Sketch Engine lexical corpus manager and analysis software.

TABLE 11.7 Collocation candidates (terms) by co-occurrence count: Spain

\begin{tabular}{ll}
\hline French & Italian \\
\hline Portugal (10) & Governo (12) \\
Pays (10) & Guerra (7) \\
France (3) & Franco (5) \\
& Italia (5) \\
& Paese (5) \\
\hline
\end{tabular}




\section{French}

Espagne (87)

UE (51)

Podemos (41)

Espagnols (38)

Brexit (20)

Sanctionner (20)

Austérité (18)

Nationalistes (14)

Catalogne (13)

Rajoy (10)

\section{Italian}

\author{
Spagna (197) \\ Spagnoli (54) \\ Podemos (31) \\ Spagnola (28) \\ Dittatura (21) \\ PSOE (20) \\ Gibilterra (19) \\ Catalani (14) \\ Dittatore (12) \\ Rajoy (10)
}

The extraction of the most common key words in the French and Italian corpora, as shown in Table 11.8, reveals that most key words are related to Spanish politics. Very few of them are linked to the economic crisis (as French "sanctionner" and "austérité").

\section{Conclusions}

This paper has presented a practical text-linguistic approach to the analysis of national stereotypes on social media. Since lexical approaches are only of limited applicability with small data, the approach outlined here is rooted in text actions and sentiment analysis. It distinguishes three hierarchical levels of internal organisation for text actions: main text action (what or who are we talking about?), secondary text actions (which topics related to this object/ reality/person are we talking about?) and partial secondary text actions (how do we characterise this object/reality/ person in terms of polarity?).

The proposed approach has been tested in a corpus-based study of Northern, Southern and Eastern European Facebook conversations that include Austrian, Flemish, French, Italian, Polish and Bulgarian comments about Spain. The thorough analysis of the Spain-related text actions in the six corpora has not revealed any surprising results. For the Austrian and the Flemish Spain is a rather traditional country in a heavy economic crisis and Spaniards and their politicians are not trustworthy and lazy. However, the Austrians do appreciate 
the Spanish culture and for both the Austrians and the Flemish Spain seems to remain an attractive tourist destination. The French have a more positive opinion of Spain. For them, Spain is a modern country and the Spanish are friendly and tolerant. Nevertheless, they are not always trustworthy and Spain, which is not considered a particularly stable democracy, is in a deep economic crisis. Spanish culture is viewed in a positive light. The Italians are divided in their opinions about the Spanish regarding the modernity of the country and the friendliness of its population. For most Italian Facebook users the Spanish are not trustworthy and the economic situation in Spain is as bad as in Italy. They also have a rather negative view of Spain as a tourist destination. However, for them Spain is a stable democracy. The very few Polish and Bulgarian comments about Spain cast a rather positive light on Spain and the Spaniards as a people.

Despite its problems and limitations, the analytical method explained in this paper will hopefully enable linguists to break down conversational threads about a given nation into text actions, and so draw conclusions about the presence and actional nature of national stereotypes in text corpora.

\section{Bibliography}

Brandt, Margareta, Inger Rosengren (1992). 'Zur Illokutionsstruktur von Texten', Zeitschrift für Literaturwissenschaft und Linguistik, 86, pp. 9-51.

Corvacho Valencia, Juan Manuel et al. (2014). 'La imagen de la Marca España en las redes a través de su campaña I need Spain', Historia y Comunicación Social, 19, pp. 501-512.

Czachur, Waldemar (2007). Textmuster im Wandel (Dresden: Neisse).

Dąbrowska, Jarochna (1999). Stereotype und ihr sprachlicher Ausdruck im Polenbild der deutschen Presse. Eine textlinguistische Untersuchung (Tübingen: Narr).

Dinnie, Keith (2008). Nation branding. Concepts, issues, practice (Oxford: Butterworth-Heinemann).

Fairclough, Norman (2003). Analysing Discourse. Textual analysis for Social Research (London: Routledge).

Geis, Michael (1995). Speech acts and conversational interaction. Toward a theory of conversational competence (Cambridge: Cambridge University Press).

Golonka, Joanna (2009). Werbung und Werte. Mittel ihrer Versprachlichung im Deutschen und im Polnischen (Wiesbaden: VS Verlag).

Gülich, Elisabeth (1986). 'Textsorten in Kommunikationspraxis', in Werner Kallmeyer (ed.), Kommunikationstypologie. Handlungsmuster, Textsorten, Situationstypen (Düsseldorf: Schwann), pp. 15-46. 
Hollander, Justin et al. (2016). Urban Social Listening. Potential and Pitfalls for Using Microblogging Data in Studying Cities (London: Palgrave).

Janich, Nina (2005). Werbesprache. Ein Arbeitsbuch (Tübingen: Narr).

Kohut, Andrew (2012). European Unity on the Rocks. Greeks and Germans at Polar Opposites (Washington: Pew Research Center).

Laamiri, Mohammed, Boussif Ouasti (2001). 'Le portrait mythique de la femme dans le miroir euro-marocain', Hermès, 30, pp. 117-124.

Leerssen, Joep (2007). 'Image', in Manfred Beller, Joep Leerssen (eds), Imagology. The cultural construction and literary representation of national characters. A critical survey (Amsterdam, New York: Rodopi), pp. 342-345.

Moreno Ortiz, Antonio, Chantal Pérez Hernández (2013). 'Lexicon-Based Sentiment Analysis of Twitter Messages in Spanish', Procesamiento del Lenguaje Natural, 50, pp. 93-100.

Ortner, Heike (2014). Text und Emotion. Theorie, Methode und Anwendungsbeispiele emotionslinguistischer Textanalyse (Tübingen: Narr).

Ossenberg, Stefan, Rupprecht Baur (2016). 'Wie kommen wir an die Bilder in unseren Köpfen? Zur Methodologie einer interkulturell anwendbaren Stereotypenerhebung', Linguistik Online, 79.5, pp. 9-24. http://dx.doi.org/10.13092/lo.79.3331 [accessed 28.07.2018].

Papadopoulos, Nicolas et al. (2016). 'From Nation to Neighbourhood. Branding and marketing places', in Francesca Dall'Olmo (ed.), The Routledge Companion to Contemporary Brand Management (London: Routledge), pp. 458-472.

Pizarro, Juan (2014). Informe anual de la imagen económica de España en Twitter (Madrid: R.I. Elcano).

Pümpel-Mader, Maria (2010). Personenstereotype. Eine linguistische Untersuchung zu Form und Funktion von Stereotypen (Heidelberg: Winter).

Quasthoff, Uwe, Erla Hallsteindóttir (2016). 'Stereotype in Webkorpora. Strategien zur Suche in sehr großen Datenmengen', Linguistik Online, 79.5, pp. 347-379. http://dx. doi.org/10.13092/lo.79.3349 [accessed 01.07.2018].

Rehbein, Jochen (1977). Komplexes Handeln. Elemente zur Handlungstheorie der Sprache (Stuttgart: Metzler).

RI Elcano (2016). 6ª Oleada Barómetro Imagen de España, mayo-junio 2016 (Madrid: RI Elcano).

Rothkegel, Annely (1984). 'Frames und Textstruktur', in Annely Rothkegel et al. (eds), Text-Textsorten - Semantik (Hamburg: Buske), pp. 238-261.

Rothkegel, Annely (1992). 'Text pragmatics and computational modelling', in Dieter Steiner (ed.), Cooperating with Written Texts. The Pragmatics and Comprehension of Written Texts (Berlin: De Gruyter), pp. 665-684.

Saeed, John (2009). Semantics (Oxford: Blackwell). 
Sánchez Prieto, Raúl (2017). Text linguistics for the contrastive study of online customer comments. Text-linguistic patterns in German, Dutch, Spanish and French hotel comments and reviews (Tübingen: Narr).

Schröder, Thomas (2003). Die Handlungsstruktur von Texten. Ein integrativer Beitrag zur Texttheorie (Tübingen: Narr).

Stock, Wolfgang, Mechthild Stock (2013). Handbook of information science (Berlin: De Gruyter).

Taboada, Maite et al. (2011). 'Lexicon-Based Methods for Sentiment Analysis', Computational Linguistics, 37.2, pp. 267-307.

Taboada, Maite (2016). 'Sentiment Analysis. An Overview from Linguistics', Annual Review of Linguistics, 2, pp. 325-347.

Unger, Johann, Ruth Wodak, Majid KhosraviNik (2016). 'Critical discourse studies and social media data', in David Silverman (ed.), Qualitative Research (London: Sage), pp. 277-293.

Valtysson, Bjarki (2012). 'Facebook as a digital public sphere. Processes of colonialization and emanicipation', triple, 10.1, pp. 77-91.

Van Dijk, Teun (1984). Prejudice in Discourse. An Analysis of Ethnic Prejudice in Cognition and Conversation (Amsterdam: Benjamins).

Vilinbahova, Elena (2014). 'Stereotype in linguistics. History of the study',Jazyk i rečevaja dejatel'nost', 14, pp. 214-221.

Von der Lage-Müller, Kathrin (1995). Text und Tod. Eine handlungstheoretisch orientierte Textsortenbeschreibung am Beispiel der Todesanzeige in der deutschsprachigen Schweiz (Tübingen: Niemeyer). 
PART 5

The Economic Crisis in Literature 


\title{
Resilient Stereotypes in Recent Crisis Novels from Spain
}

\author{
Ana María Fraile
}

\begin{abstract}
After the outbreak of the financial crisis of 2008, the hegemony of the politics of financial debt was largely perceived in Southern Europe as an internal colonisation, with Germany as the leading economic power. According to this view, Southern Europe became the trial ground for neoliberal late capitalism. The unequal impact of the crisis on the different European economies resulted in the unwelcome reactivation of old stereotypes that hinder the European process towards transnational economic, social and cultural convergence. This contribution considers fiction as a privileged space for the nuanced representation of the complexities characterising the current moment of European liquid modernity and presents the novel as an important arena for critical reflection. It discusses a selection of recently published novels from Spain, which, set in the aftermath of the construction boom and the unveiling of systemic corruption, register the multiple negative consequences of the European austerity policies and grapple with the resurfacing of the stereotypical constructs of national identities through humour, satire, and social and political critique. Among the authors considered are Almudena Grandes, Germán Gullón, Rafael Chirbes, Luis García Jambrina, and Belén Gopegui.
\end{abstract}

\section{$1 \quad$ Introduction}

Our era is perceived as one of uncertainty and precariousness, accentuated by the current global hegemony of neoliberal capitalism and its collateral effects, the crisis of national sovereignty, the unequal impact of globalisation, unequal access to instant electronic communication, unprecedented migration flows, accelerating urbanisation, neo-colonialism, climate change, the overexploitation of natural resources, market volatility and the subsequent polarisation of

(C) ANA MARÍA FRAILE, 2021 | DOI:10.1163/9789004436107_014

This is an open access chapter distributed under the terms of the CC BY-NC-ND 4.0 license. 
wealth and society. ${ }^{1}$ The instability, turmoil and violence resulting from the coalescence of these developments prompts a re-evaluation of the Western ideology of modern progress, as European societies resort to different strategies of resilience - from the emergence of extreme political parties on the right and the left, to the isolationism implicit in Brexit, and the reaction against asylum policies. Unsurprisingly, the very different effects of the 2008 financial crisis on the various European economies has also caused the resurgence of dormant stereotypes of national identity.

Parallel to an increasing perception of vulnerability, the concept of resilience has gained popularity in the West, to the extent that The Guardian proposed the term as the word of the year 2012. ${ }^{2}$ Though emerging from the realm of the natural sciences, the term has come to denote the capacity of nature and of humankind to withstand shocks by being able to adapt, renew and even thrive in the face of adversity and destructive conditions. In Spanish, the term resiliencia still rings as an Anglicism and is rarely used to talk about the strategies to overcome the consequences of the recent multi-layered crises caused by the financial crash of 2008. However, the successive conservative Governments led by Prime Minister Mariano Rajoy of Partido Popular (22 Dec. 2011-7 Jun. 2018) consistently resorted to the neoliberal discourse of resilience to encourage people in Spain to put up with the austerity policies that the IMF and 'the Troika' demanded.

A number of novels published recently in Spain testify both to the resilience of the Spanish people in times of economic, social, political and cultural turbulence, and to the resilience of stereotypes. Taking fiction as a source of inquiry that may contribute to create an 'imaginated discourse', 3 this essay offers to look at a selection of five recently published novels from Spain that create a narrative of endurance, struggle and hope in the face of the traumatic reality of the 2008 financial crisis by working with national stereotypes. La codicia de Guillermo de Orange (2013) by Germán Gullón, Bienvenida, Frau Merkel (2015) by Luis García-Jambrina, En la Orilla (2013) by Rafael Chirbes, Los besos en el

1 Research for this paper has taken place within the framework of the research project Narratives of Resilience: Intersectional Perspectives about Literature and Other Contemporary Cultural Representations (FFI2015-63895-C2-2-R), graciously funded by the Spanish Ministry of Economy and Competitiveness.

2 See Juniper (2011).

3 I follow Leerssen (2000), Leerssen (2007a), Leerssen (2007b) in the use of the term "imaginated discourse" to refer to a discourse that is "concerned with the characterological explanation of cultural difference," articulating "a moral, collective-psychological motivation for given social or national features" Leerssen (2007a), p. 28, and relying "on imputations of national character, rather than on testable fact", Leerssen (2007 b), p. 342. 
pan (2015) by Almudena Grandes and Belén Gopegui's El comité de la noche (2014) were reviewed by the major national newspapers upon their publication, and were the object of interviews and discussions in radio and television shows. However, to date, only Chirbes' has been translated into English as On the Edge (2016). The authors considered are avowedly leftist intellectuals, whose fictions register via humour, irony, satire, and social and political critique the perception that the cleavage between Northern and Southern European countries has been accentuated, on the one hand, by the European and national economic policies during the crisis and, on the other, by the reactivation of discourses that rely on stereotypical constructs about national identities. Therefore, these novels capitalize on historical stereotypes that include self-images of Spanish identity, i.e., the characterological reputation that Spaniards currently share of themselves, hetero-images, i.e., the opinion that others have about the Spanish purported character, and meta-images, a term used to refer to "how a nation believes it is perceived by others." $\mathrm{My}$ aim is to ponder whether and how these fictional narratives offer an opportunity to study the role of stereotypes in engaging the collective imagination in the creation of a metanarrative that contributes to keep a positive sense of identity and dignity in the midst of crisis.

I propose to offer a brief survey of the key tropes and pervading stereotypical images of Spain used on and off in the course of history to refer to the Spanish national character both within Spain and internationally, before exploring the extent to which the proposed novels draw on this tradition in order to sanction, negate, mock, or extend it.

\section{The Historical Construction of the Spanish Character}

Spain's image appears as a palimpsest of layered stereotypes of complex origins in the long European history, created as much by hetero-images, the gaze of non-nationals, as by the self-image cultivated within Spain. Lucena Giraldo classifies the stereotypes about Spain in three main categories that encompass the Spanish Black Legend, the Romantic image of Spain as an exotic country, and the re-evaluation of Spain's image during the Democratic Transition period after $1975 \cdot{ }^{5}$

4 Leerssen (2007b), p. 344.

5 See Giraldo (2006). 
The Spanish Black Legend, a term coined by Julián Juderías at the beginning of the twentieth century, ${ }^{6}$ results from the (hetero-)images emerging from the convergence of religious and political developments. It has its roots as much in the Spain of the Inquisition, a champion of Catholicism against Protestantism, Judaism and the Islam in the Middle Ages, as in the perception of Spain as a cruel and despotic state involved in numerous conflicts of interests with other European and non-European powers after becoming an Empire in the sixteenth and seventeenth centuries. ${ }^{7}$ Contributing to the Spanish Black Legend were John Foxe, Father Bartolomé de las Casas, and William of Orange, among others. The latter's exaggerated accusations of "murder, arrogance, avarice, excessive territorial ambition, fanaticism, cruelty, brutality and lack of education" in the Apology (1581) gained widespread credence, ${ }^{8}$ and these stereotypes about the Spanish character remained unchanged until the beginning of the nineteenth century. ${ }^{9}$

The change of dynasty in Spain in 1700 marks the transition to a romantic and Orientalised view of Spain in the nineteenth century. Whereas the French justify the invasion of Spain as an attempt to instil the Enlightenment ideals and liberate a vicious, lazy and devious people from tradition, clericalism and secular intolerance, the English embrace the romantic view of Spaniards as a brave, passionate people rising up in arms to defend their freedom against the French tyrants. They foster an exoticism that is enhanced by a focus on the legacy of Arab culture, the values of a pre-modern, pre-capitalist society, and the loyalties and spontaneity that are encapsulated in the bandits and Carmen types.

The twentieth century elaborates upon all these stereotypes, with the Spanish Civil War (1936-1939) triggering a neo-romantic image that blends the Black Legend with the idea of a free people in arms. The ensuing post-war period, marked by Francoist authoritarianism, National Catholicism, militarism, and conservatism, congeals the image of Spain as archaic and isolated. In the 196os the industry of tourism that helps to open the country to the outside world also revives the romantic stereotypes regarding Spain's exceptionalism as a nation anchored in erstwhile values, passion, sex, fiesta and siesta. After the dictator's death, Spain's enthusiastic embrace of and inclusion in the European Union contributed to its 'normalisation' and modernisation. The view of Spain before the 2008 crisis was that of a successful country that had restored

\footnotetext{
6 See Juderias (1914).

7 See López de Abiada (2007), p. 243.

8 Dadson (2004), p. 144.

9 See López de Abiada (2007), p. 244.
} 
democracy in a model Transition from a 40-year-long dictatorship, performing what is known as the Spanish (economic) Miracle, while preserving a passion and creativity that situate the country in the post-modern cultural arena, for example in Calatrava's architecture or Almodovar's films. However, after the crisis, this positive image was readily overturned in the political and media discourses both abroad and within, reverting to that of a misgoverned, inefficient and corrupt country that had lived above its means. Counteracting this negative stereotype, other voices emerged within Spain. In particular, the $15^{-\mathrm{M}}$ grassroots movement re-energised the image of a proud Spanish people rising against the tyranny of national and international politics in defence of their civil liberties. ${ }^{10}$ These bipolar perceptions constitute what Joep Leerssen terms "imagemes", or deep structures generating a polarity of contrasting attributes." They continue to the present to the extent that two contrasting images of Spain coexist.

\section{Dealing with National Stereotypes in Spanish Crisis Novels}

The novels selected for this study were published between 2013 and 2015, during the peak of the economic crash in Spain. Coeval with the crumbling of social prosperity and of Spain's positive image, these novels engage in the revision and adaptation of stereotypes that prove resistant to change.

Germán Gullón's La codicia de Guillermo de Orange (The Greed of William of Orange) capitalizes on the historical clash between Northern and Southern Europe, taking Holland and Spain as case studies. ${ }^{12}$ This confrontation, which is well documented by historians, is also well represented in literary works that testify to stereotypical tropes which seem to have resurfaced during the

10 The Movimiento 15-M, also called Movimiento de los indignados, takes its name from the demonstrations of 15 May 2011 that took place all over Spain, originating a series of peaceful protests aiming to promote a participative democracy against the two-party system and its purported subservience to neoliberalism, banks and multinational corporations. Protesters also demanded to confront the alleged current crisis of the institutions that hampers the real division of powers and damages democracy. Along with the Arab Spring and the Greek protests, the 15 -M Movement inspired the global Occupy Movement.

11 See Leerssen (2000) and Leerssen (2007a), pp. 29, 33.

12 Germán Gulllón is Emeritus Professor of Spanish Literature, as well as a writer and literary critic. He graduated from the University of Salamanca, got his PhD from Texas University and began his teaching career at the University of Pennsylvania. He became Chair of the Spanish and Classics Department at the University of California Davis, and the Director of the Cervantes Institute in Utrecht. 
current crisis. ${ }^{13}$ Similarly, the novel tracks the present-day philias and phobias back to the enmities caused by historical imperialistic power games. In the novel, the revival of historical animosities in present-day Dutch politics concerns Richard Vaessens, an influential professor holding the Spanish Chair at Amsterdam University, who notes that "Willem van Oranje-Nassau's ideas [...] are embedded in current Dutch culture, undoubtedly due to the crisis. [...] The stereotypes against the Spaniards help speculators, who are betting for the economies to crash in the Europe warmed by the Mediterranean sun."14 The book opens with the Dutch defeat against Spain in the final of the Soccer World Cup Championship in 2010, an event that enrages Joost van der Linden, who has a great hatred for all things Spanish. He owns a corporation called Orange, after the monarch and founding father of the Netherlands William of Orange, whose Apologia (1581) defends his right to rebel against what he considered the tyranny of Phillip II of Spain and Portugal (1556-1598). After the Dutch soccer defeat, Joost plans to offer as a Christmas gift to friends and good clients thousands of copies of the Apology in Dutch, German, and English. This is part of Joost's strategy to make financial profit from an advertising campaign to discredit Spain, and further devalue its rating in the market. Joost tries to convince his associates Sloterdijk and Toorn that the Apology can serve their corporative interests, the same as it served the nationalist Dutch interests in the past: "It helped to spread the Spanish Black Legend, also fostered by the English, an effective weapon for the discredit of the Spanish Empire in the sixteenth century. Its publication will contribute to our corporation's current

13 See Zacharasiewicz (2010), pp. 24, 142-147, 468-502. An example of the stereotyping at work in the present construction of a cultural rupture between Northern and Southern Europe is the use of the pejorative term P.I.G.S. to allude to the economies of Portugal, Italy, Greece and Spain. Coined by the Financial Times and Barclays Capital in 2010, this derogatory acronym epitomizes the stereotypes held against Southern Europe by its Northern neighbours. Ireland also became associated with the term, either replacing Italy or changing the acronym to PIIGS. Sometimes a second G (PIGGS or PIIGGS), for Great Britain, was also added. As a counterpoint, there is a general perception in these Southern countries that Northern Europeans are self-righteous, interventionist, greedy peoples, lacking solidarity and empathy, and possessing a sense of unjustified moral superiority with respect to Southern Europeans, based on their greater economic development. This state of affairs is humorously captured in Yanko Tsvetkov's bestselling Atlas of Prejudice, where Germany appears from Spain's point of view as "Cruella de Merkel". Similarly, from Greece's perspective, Central Europeans, and Germany in particular, are perceived, according to Tsvetkov's map as "imperialists," "freaks," and "egoists." See Tsvetkov (2012), n.p.

14 Gullón (2013), p. 27. All the quotations from the novels are my translation into English, except for Chirbes', for which I use Margaret Jull Costa's translation. 
objective to shatter the confidence in the Spanish financial debt."15 Jan, however, articulates his scruples, arguing that "it is the moment for the Germans and Dutch to show some solidarity after the glorious years following the adoption of the Euro, when we got rich due to the rise of prices [in Spain]."16 Like William of Orange, who hired German mercenaries at his own expense to launch his insurrection against the Spaniards, Joost does not hesitate to blackmail journalists and the Dutch university authorities, and to pay mercenaries to intimidate those who threaten to unveil their game. The Orange Corporation thrives by reviving the stereotype of the hedonist Spaniards who enjoy life too much - purportedly partying instead of working, dilapidating the European funding they received for decades and basking in corruption. This supports the conclusion that Spaniards deserve their fate because they've lived beyond their means.

Ellen, a Dutch graduate student majoring in Spanish, stands in stark contrast to these characters' Hispano-phobia. Her research discloses Joost van der Linde's financial conspiracy against Spain, simultaneously revealing his businesses' strong roots in ultra-nationalism and racism towards Spaniards.

The novel reveals the media's construction of an imaginated discourse that, in connivance with politicians and the economic powers, creates the cleavage between the North and the South of Europe in Holland. Wouda, for instance, remembers a political campaign around

the excessive contribution of Holland to the EU. It thrived on the voters' ignorance, hiding from them that the beneficiaries of EU funding were actually the German and Dutch exporters, because if good roads were built in the South and East of Europe, our cheese and chemicals, and the German appliances would get there faster. You won't hear complaints from Bosch, AEG, Siemens or Miele. We weren't exactly any Pollyanna ourselves. Rather, we have a good eye for business. ${ }^{17}$

Eventually, it is the transnational Spanish-Dutch cooperation between academia, the press and the police that thwarts, at least momentarily, the financial and physical violence exerted by Joost van der Linden's greed. Resistance to stereotypical images of Spain is achieved precisely by the same means that spreads the stereotypes, namely, the globalisation of information through electronic instant communication and fast travel.

\footnotetext{
15 Gullón (2013), pp. 15 f.

16 Gullón (2013), p. 16.

17 Gullón (2013), p. 69.
} 
Thus, Gullón's text dwells on ingrained historical images containing compounded contradictory polarities (imagemes) only to unveil the fallacy of the binary and to point towards the rejection of the meta-image. However, in the process of dispelling the negative heteroimage of Spain as - according to the text - created in Holland, the novel may be reinforcing a stereotypical heteroimage of the Dutch for the Spanish reader of the novel.

If Gullón's novel offers a critique of the Dutch for aggravating the precarious financial situation of the Spanish economy so as to exact an economic benefit while punishing and humiliating the Spaniards, Luis García-Jambrina's Bienvenida, Frau Merkel (2015) is a scathing self-critique in the Spanish literary tradition of el esperpento, the grotesque parody mastered by nineteenth-century classic writer Ramón del Valle-Inclán. ${ }^{18}$ It also pays homage to the 1953 classic film by Luis García Berlanga, Bienvenido, Mr. Marshall by recounting in the same humorous and satirical vein the frustrated efforts of a little town in La Mancha to be saved from economic collapse by the intervention of a foreign power. Whereas in Berlanga's film the inhabitants of Villar del Río pin their hopes on the Marshall Plan which helped reconstruct Western Europe after World War II, but ignored a torn Spain equally distraught after its Civil War, in García-Jambrina's novel salvation lies in the possibility of Germany, as the embodiment of the EU's political and economic power, helping Villar del Campo out of its bankruptcy. Hit by the financial crisis, all the corruption and bad management of the previous decades come to the surface, and shatter the myth of the 'Spanish miracle' after the democratic transition of 1975. When the Mayor Germán García learns that Merkel is going to pass nearby on her way to a European summit to be held in Toledo, he convinces his neighbours to put up a farce and recreate their town as a model German village. Germán hovers between the heroic idealism of Don Quixote and the clever picaresque of the anti-hero Lázaro de Tormes, the two literary referents in the Spanish cultural imaginary.

The plan he concocts evokes the heteroimage of Germany in Spain: "If we manage to convince the German chancellor that we're a truly austere, serious, disciplined and hard-working people, that is, just like them, I'm sure she will help us out of this crisis with some European recovery program, a sort of Merkel Plan for those of us who are truly determined to improve and change." 19 The

18 Like Gullón, García-Jambrina studied Hispanic Philology at the University of Salamanca, where he currently teaches Spanish Literature. Besides his academic and critical work, he is the author of two collections of short stories and eight novels that combine historical and noir genres.

19 García-Jambrina (2015), p. 18. 
novel's satire emerges from the dynamic tensions between the self-images and the heteroimages emanating from both the Spanish and the German protagonists. Thus, the Mayor's emphasis on contrition and transformation in the way of carrying out business, shunning corruption and the dilapidation of public funds in unsustainable projects, is soon revealed as a devious manoeuver to proceed as usual, making easy money by literally selling an image that does not correspond with the reality it represents, but that actually could transform that reality. This becomes apparent in the Mayor's words after proposing to convince Merkel they are just like the Germans: "Not to mention the publicity all this would bring; we'd be trending topic in Twitter and all the social media, we'd be all over the press, including the digital newspapers, and the TV and radio news would open with us. This would make foreign capital interested in investing in our town, and bankers would give us soft loans to refinance our debt if necessary."20

Furthermore, the text extends the stingy satire to the Germans, represented by Petra, a German artist who resides in Spain. Petra articulates an imaginated discourse by singling out the 'typical' characteristics of Spaniards and highlighting the stereotypical differences between Spain and Germany, consequently portraying Spaniards as the Other of Germans. Focusing on the antithetical economic situation of both countries during the crisis, she finds a characterological explanation of cultural difference (and of the different economic results) in religion, adopting a moral superiority that rejects contestation on the part of her interlocutor, as the following dialogue between Petra and the Mayor in the village's church demonstrates:

"For starters, Catholics are profligate and luxury lovers: it suffices to look at that altarpiece", she explained, pointing towards the altar, "full with images and gilded figures, even in this little town, whereas us, the Lutherans are sober and thrifty. On the other hand, it's evident that you, the Catholics, go through life sinning and getting in debt and then you fix it all with a confession. [...] And if that were not enough, you take out of your sleeve that invention of the indulgence, so criticized by Luther, which is something like getting a loan so that you can continue getting into debt. This clearly demonstrates that Catholicism goes against the economic and fiscal health of a country, and if you don't believe me, there're Ireland, Italy, Portugal and Spain itself, all of them Catholic countries."

"And what about Greece?" 
"The Greeks are even worse, as they pass for being Orthodox, and you see the result", she added with a certain contempt. ${ }^{21}$

When Germán protests that most Spaniards are only nominally Catholic, Petra-in tune with the inflexibility and harshness that her name impliesvehemently defends that that is typically Catholic: "as good Catholics you're hypocrites; actually, it could be argued that that dissociation between believing and practicing is exclusively yours, as it hardly appears in other religions."22 Next, Petra resorts to bio-cultural essentialism to close the discussion:

As much as you deny or disguise it, Catholicism is something the Spanish people carry in their genes, your national DNA. You don't have but to see how much they like festivities, which are religious for the most part, or the fact that he who lives carefree is called in Spanish a "vivalavirgen," [or "long-live-the virgin"]. That explains that the Counter Reformation succeeded here, or that religion continues being a taboo, a sensitive issue if anyone dares to call it into question. ${ }^{23}$

The irony is that Petra makes a living out of the various official subsidies to culture and the arts offered by the Spanish administrations, which in turn may come from European funding, which implies, like in Gullón's novel, that Northern Europeans also benefit from the money put into less economically buoyant Southern countries. Petra's character is thus exposed as hypocritical, too, contradicting the clear-cut cultural line separating Southern and Northern Europeans that she drew in her imaginated discourse.

Drawing on the Spanish Black Legend, Rafael Chirbes' En la orilla (2013) presents the Spanish character in a much grimmer light. Continuing with the theme at the core of his celebrated previous novel Crematorio (2007), Chirbes focuses on the consequences of the real estate bubble in Levante, and by extension, elsewhere in Spain. En la orilla won a number of relevant awards and has reached an international readership with its translation into English. ${ }^{24}$ The

\footnotetext{
$21 \quad$ García-Jambrina (2015), p. 70.

22 García-Jambrina (2015), p. 70.

23 García-Jambrina (2015), pp. 7of.

24 Rafael Chirbes (27.06.1949-15.08.2015) is the author of four books of essays and ten novels, including his trilogy dealing with postwar Spain (La larga marcha, La caída de Madrid and Los viejos amigos), and the Crisis novels Crematorio (2007), about the Spanish real estate bubble, and En la orilla (2013). Paris-Austerlitz was published posthumously in 2016. His first novel, Mimoun (1988), was a finalist of the Herralde awards. In addition to the awards for En la orilla: Premio de la Crítica de narrativa castellana (2014), Premio
} 
mood of decay, fear, frustration, anxiety, resentment and despair infuses the novel with a sense of hopelessness and the apocalyptic feeling of being at the end of time. The marjal, the lagoon ecosystem on the outskirts of Olba, a town near Alicante that has become a dumping ground for all kinds of toxic waste, becomes a metonymy for Spain, a despoiled nation, reeking with poverty, greed, prostitution, xenophobia, Islamophobia, immigration fears, terrorist threat, human trafficking, violence, corruption, disillusion and betrayal.

The novel highlights the historical links between the current environmental decay and a corrosive immorality that seems to be inherent to the national character. Through Esteban, the septuagenarian protagonist who lives with his dog and his mute, disabled and terminally ill father, the text weaves a narrative of continuity between the callous repression of the post-civil war years and the present, bringing to the surface the connections between the destructive practices of those who won the war and their economic and social ascent in Spanish society. In the following excerpt, Esteban reminisces about the persecution and repression his Republican father tried to avoid after the war by, first, hiding in the reedbeds near the lagoon and later handing himself in to the authorities. The civil guard would chase him, and many others like him, "like animals, even burning down the vegetation. The crackle of the reedbeds burning and the sticky smell of the smoke suffocating the other marsh creatures would reach as far as Olba. To make the fire spread more rapidly, they would pour gas on the reedbeds and the scrub, which were often small islands of floating vegetation." ${ }^{25}$ Yet, destroying the natural environment where the villagers in hiding found refuge had the further purpose of creating allegiances and servitude on the part of those who were given strips of land from the drained lagoon. Consequently, those lands signify the foundational moment of present-day corruption:

It wasn't all about repression though. There was a business aspect too. On the excuse that they had to hunt down those poor wretches, the authorities encouraged the draining of the lagoons, promoted the idea of filling them in, giving swathes of swampy land to a few friends and ex-combat-

Nacional de Narrativa (2014), Premio Francisco Umbral al Libro del Año 2013 (2014), Premio Bienal de Novela Mario Vargas Llosa finalist, it was also considered best book of the year by the newspaper El País. Chirbes also won the German award $s w R$-Bestenliste for $L a$ larga marcha (1999), the book of the year Premio Cálamo for Los viejos amigos (2003) and again in 2007 for Crematorio, which also won Premio de la Crítica de narrativa castellana (2007), and Premio Dulce Chacón (2008). 
ants, granting them authority to drain and cultivate it. Greed was enough of an incentive to mobilize the volunteers for the hunts. Properties like Dalmau and La Citrícola were born out of those re-distributions. [...] La Citrícola was born out of the part of the lake handed over to Pallarés to be drained, another blue shirt who strutted about with a pistol in his shoulder holster, ${ }^{26}$ generally tyrannising the area until the late 196os, when his legal heirs took over the estate, and while they - a sign of the times have behaved rather more discreetly, they have been just as greedy, and all their dealings were wiped clean of the old ideological cobwebs: clean money without the packaging of patriotic speeches, proclamations or saber-rattling. ${ }^{27}$

Esteban himself realizes that immorality and greed have since then extended and infected almost everyone, himself included. At present, he faces eviction and jail after forging his father's signature and investing all his money and possessions in a real estate company that has gone bankrupt after the outbreak of the housing bubble and whose owner has fled the country with the money. While he pretends in front of his friends that everything is fine, he determines to put an end to his father's and his own life.

En la orilla has been acclaimed as the best novel on the Spanish economic crisis, and yet, it goes beyond the narrow scope of economics to ponder on a particular national brand of the banality of evil that results in further grimmer and more hopeless crises, if only because they are more difficult to fight, namely the moral crisis, the crisis of values, the institutional crisis, the crisis of the nation-state. Other crises, like the crisis of the Anthropocene, are rendered in an ambiguous, ironic way, like when Esteban reflects on the current concern about nature in contrast with the scarce interest in the crimes against humanity committed during and after the Civil War that remain unpunished:

now the great shrine of divinity is nature: impregnating water and mud with asphalt roofing felt, bituminous matter, glass fiber, carcinogenic asbestos, which is what Bernal Jr. did, seems far worse than the murders his father committed. If you throw a corpse into the sea, you're doing the environment a favor, supplying food for the fish to nibble on with their

26 The Blueshirts, or Camisas Azules in Spanish, were the paramilitary militia of the Falange political party, officially renamed Falange Militia in 1940 during Franco's regime. The symbolic blue colour of their uniforms sought to gain support among the Spanish blue-collar workers.

Chirbes (2016), p. 82. 
small cold mouths. The sins of the gunmen - who turned ditches into graves and peppered the walls of cemeteries with bullets, who fed the fish out at sea - those were absolved by the Transition, because apparently they were only venial sins, whereas the sins committed against the environment have no expiry date and no judge can absolve them. Let's not deceive ourselves, man is nothing very special. In fact, there are so many of us that our governments don't know what to do with us all [...]. The sleight of hand that made man the center of the universe no longer convinces. $^{28}$

Despite the negative tone of the novel, however, there is a sustained imagery in which the marsh can paradoxically act as a space of freedom, protection and regeneration, the same as carrion engenders life and beauty:

We live off what we kill. We live from killing, from what is served up to us dead: the inheritors consume the spoils of their predecessors, which nourish and strengthen them when it's time to take flight. The more carrion they eat, the higher and more majestic the flight. And, of course, more elegant. And none of this is in any way at odds with the natural condition of the world. ${ }^{29}$

Yet, the marsh's beauty appears at the end of the book as a mere mirage, and the text shuns the ideology of linear progress while reinforcing the idea of immobility and death through the imagery of dark colours and tombs: "The passing clouds reflected on the surface create an illusion of a world in constant evolution, but which is, in fact, motionless, fixed as if in an old photograph, whose sepia tones precisely match the rusty colors of the winter reeds, faced yellows and ochers and a brown so dark it's almost black, and which forms sooty clumps, the melancholy tombs of giants." ${ }^{30}$ Furthermore, the novel eschews any attempt at poetic justice by choosing Tomás Pedrós as the focaliser in its last pages. Pedrós, the crook who swindled Esteban out of his savings, has managed to escape and is ready to continue living the good life in his 'exile': "money has no homeland, just make sure you've got plenty of convertible euros or convertible dollars (is that what they call them?) in your handbag," ${ }^{31}$ he says, and the doctrine he lives by seems to serve him well. Thus,

\footnotetext{
28 Chirbes (2016), pp. $3^{2 f}$.

29 Chirbes (2016), p. 130.

30 Chirbes (2016), p. 389 .

$31 \quad$ Chirbes (2016), p. 399.
} 
the myth of the picaro or trickster figure devoid of any moral values but his own profit and survival, prevails.

In contrast with Chirbes' ominous tone, Almudena Grandes portrays in Los besos en el pan (Kisses on the Bread) an urban middle class that after the shock of being hit by the economic crisis, actively struggles to pull itself up by their bootstraps, adopting resilience strategies in the face of the political corruption and austerity measures that have the country on the edge. ${ }^{32}$ An excerpt of the novel focusing on the scene that explains its title appeared in The New York Times on 13 December, 2017. The title alludes to the traditional gesture of kissing the bread as a sign of gratitude, even in the midst of misfortune, as the narrator of this polyvocal novel was taught to do as a child during the times of scarcity of the Spanish civil war and the post-war period. Grandes' novel targets a Spanish audience that is well acquainted with the recent historical political and social developments in the country, readers who may identify with one or more of the myriad characters inhabiting the novel. The text draws on the myth of the heroic Spanish people rebelling against tyrants and invading foreign powers, which in the novel's historical juncture are global neoliberalism and its national and supranational defenders, the Spanish government and the 'troika' formed by the European Commission, the European Central Bank, and the International Monetary Fund. Los besos en el pan highlights the various personal and collective strategies of survival developed by Spanish society to avoid succumbing to the crisis and its various nefarious manifestations unemployment, evictions, divorces, etc.

A key buffer the text highlights is the family, which continues functioning as a nurturing and indispensable social structure when other institutional structures fail. The other interesting development involves social solidarity and the people's capacity and willingness to join forces to contest, reverse and direct institutional decisions that affect their lives. Regarding the former, the novel establishes intergenerational links, highlighting the role of grandparents. They

32 Almudena Grandes is the author of thirteen novels and two collections of short stories, among other works. She is an outspoken leftist intellectual and a well-known public figure in Spain. Like Chirbes, she graduated in History and her fiction reflects her interest in the postwar and the Transition periods, as well as their continuing effects on the quotidian reality of present-day Spain. Her first novel, Las edades de Lulú (1989), won the award La Sonrisa Vertical and became a best-seller, translated into more than twenty languages. It was adapted to the screen in the homonymous film directed by Bigas Luna. Since then, she has received numerous literary awards and many of her novels have been turned into films and TV series. Among her most important awards are Premio José Manuel Lara and Premio del Gremio de Libreros de Madrid, for her novel El corazón helado (2007), and the Elena Poniatowska Award she received in Mexico for the novel Inés y la alegría (2010). In 2020 she received the Jean Monnet Prize for European Literature. 
not only sustain their unemployed children and grandchildren with their care and usually meagre pensions, but act as the living memory of the Spanish people's ordeals of the twentieth century, and the holders of the survival mechanisms necessary in times of crisis. The narrator establishes already in the prologue the importance of cultural memory, regretting - like Gullón's and Chirbes' characters - the political and social pact of forgetting at the foundation of the Spanish Transition to democracy, which resulted in the apparent erasure from collective consciousness a history of sheer poverty, but also of the necessary audacity to confront adversity:

Thirty years ago, in Spain, children inherited poverty from their parents, but also dignity, a way of being poor that was never undignified. We learned to never stop fighting for a better future, to never give up [...]. Later, they told us we had to forget, that [...] to build a democracy it was essential to look forward, to pretend nothing had happened. And by forgetting the bad, we Spaniards also erased the good [...], we lost touch with our tradition, with the values that now could help us overcome this new poverty. This deprivation has been foisted on us from the very heart of that Europe that was supposed to make us rich, and has stolen from us a treasure that cannot be bought with money. Today, this neighbourhood dwellers are not just broke; they are lost, stunned and confused, as disoriented as a spoiled child whose toys have been taken away. That child does not know how to make his voice heard, claim what was his, denounce the robbery or stop the thieves.

If our grandparents saw us, they would first double-up with laughter, then die of shame. For them, our economic slide would be a mere inconvenience, not a crisis. Because Spaniards, who for centuries knew how to be poor with dignity, never knew how to be docile.

Never, until now. ${ }^{33}$

In tune with the narrator's perspective, Martina offers her grandson her civil war and post-war experiences as a counterpoint to the current crisis, insisting that "one cannot just accept whatever, but must take the reins, refuse to accept all this ruin."34

33 Grandes (2015), pp. $16 f$.

34 Grandes (2015), p. 41. Joaquín Estefanía provides a counterpoint to this image of grandparents in his recent book Abuelo, ¿cómo habéis consentido esto? (2017), drawing attention to the responsibility of the generation of elders for the mistakes that have led the country and the world to the current situation. 
The novel elaborates, therefore, upon the trope of the romantic image of Spaniards as proud and brave people, readily mobilising in defence of their values and freedoms, as it captures the shift from political apathy and disaffection to active engagement in local politics in solidarity with the weakest members of the community, namely, the immigrants, battered women, the rapidly increasing number of families facing eviction, children in impoverished families, the elderly and the sick. Consequently, there is a focus on citizen initiatives that both defy laws that are perceived as unjust and result in the emergence of Community Associations.

The public Health System, which Spaniards take great pride in, comes under scrutiny in this novel. In the midst of a Government campaign aiming to mobilize public opinion against civil servants so as to neutralize any opposition to lower their salaries, decimate their numbers, privatize public services in schools and hospitals, etc., the novel captures the atmosphere of popular struggle and resistance that materialised in the movements called 'mareas': "The Green Tide" in defence of Public Education, the "White Tide" in defence of the Public Health System and so on and so forth. In the novel, one of the doctors explains to an elderly patient of his why the hospital staff are preparing to protest against the Regional Government orders to shut it down. His words stress the cynicism of neoliberal policies that, in connivance with the private sector, are depleting the public treasury:

The Regional Government wants to close the clinic [...]. They say that this hospital is obsolete, bullshit, that it isn't profitable, bullshit, that this neighbourhood is overfunded, bullshit, that our work plan is not efficient, lie upon lie upon lie [...]. And what will they do then, those rascals? Demolish the building, build luxurious condos and make a fortune, as usual $[\ldots] \cdot{ }^{35}$

When the time comes for a demonstration, the whole neighbourhood shows up, including Venancio, the ultraconservative elderly man whose wife with Alzheimer Disease receives the daily visits of social workers and nurses at home.

Grandes' novel touches upon many other current concerns - corruption, unemployment, immigration, gender crossing, homosexuality, gender violence, and the protection of children. Empathy, love and unity prevail against the backlash of the economic crisis. There is an awakening of the people, the rise 
of solidarity and the realisation that people need to empower themselves by making their own politics, organising themselves as communities with agency.

Belén Gopegui's El comité de la noche (The Night Committee) also connects the crisis to the strong emergence of grassroots activism directed to resist the Government's alliance with neoliberal capitalist powers. ${ }^{36}$ Gopegui found the inspiration for the novel's plot when she read the news published by Europa Press in 2012 about a multinational pharmaceutical corporation that intended to pay seventy euros per week to unemployed people who became blood donors. The commodification of human organs does not only make economic profit via the exploitation of the vulnerability of human beings. It also turns life into capital and divides humanity into those who can buy their own wellbeing and survival and those whose right to life and health is disregarded given their precarity, a term coined by Judith to convey the vulnerability artificially and differentially inflicted over human beings due to gender, class, race, ethnicity, sexuality, and other categories. ${ }^{37}$ Thus, Gopegui tackles head on two contemporary ethical problems or concerns, that of the creation of the subhuman and that of the ethical regulation of bio-technological human enhancement leading to a posthuman era. The Night Committee is a powerful critique of the generalisation of vulnerability caused by the connivance of national states with the neoliberal forces of late capitalism that thrive precisely on people's precariousness. Like Grandes' Los besos en el pan, this novel takes resilience one step beyond individual malleability and resistance by countering "the authority of capital" with social democratic mobilisation. ${ }^{38}$

At the novel's opening Álex, a young doctor who has been fired from her last job after the privatisation and closing of public hospitals and the shrinking of staff contracts and salaries in private clinics, returns to live with her parents. Jobless at thirty-three and a single mother after the separation from her husband, she faces an existential crisis. Far from a drawback, this insight constitutes a revelation that allows her to reinvent herself away from her personal

36 The novel won the award Otra Mirada, Premios Cálamo 2014. Belén Gopegui studied Law at the Universidad Autónoma de Madrid and has worked for several newspapers. She is the author of thirteen novels, one play, several film scripts, among other works. She has won various national and international literary awards, among which, Premio Iberoamericano de Primeras Novelas "Santiago del Nuevo Extremo" for her first novel, La escala de los mapas, vir Premio de Narrativa Española Dulce Chacón for Deseo de ser punk, and her novel La conquista del aire adapted to the screen by Gerardo Herrero as Las razones de mis amigos.

37 See Butler (2004); Butler (2009).

38 Gopegui (2014), p. 256. 
history and all the external circumstances that have determined it so far. Thus, Álex joins a group of transnational scope that aims to prevent global pharmaceutical corporations from convincing the EU to pass legislation for the liberalisation of the blood trade. The vision of this semi-clandestine group is to build up a new world without necessarily pulling down the foundations of the current one, relying instead on bottom-up mutation and transformation: "If we began building up everything, communities, cooperatives, occupy movements, evicted proprieties, networks, new relations, if we could go on mutating, may be the war would not need to be bloody nor long nor devastate everything."39 However, for this vision to succeed, Álex and her group realize, the mutation has to entail the community and strategically take into account a politics of location..$^{40}$ Like Grandes, Gopegui draws on the romantic image of the Spanish people as brave, ingenious and defiant, rising up against oppression and joining in solidarity against injustice. Gopegui, however, goes beyond Grandes' portrayal by pointing at the transnational nature of the struggle. Thus, the social activism of the protagonists reaches European and global dimensions with the networks and interconnections they help establishing.

\section{4 Conclusion}

To conclude, this survey suggests that the Spanish authors in this limited selection render a view of the construction of a Spanish identity in the wake of the European crises that depends as much on the Spanish self-image as on their meta-image - i.e., the Spanish perception of how Spain is shaped by the gaze of other countries. This is the case in Gullón's novel regarding the historical stereotypes that prompt the plot about the rival relations between the Netherlands and Spain. Likewise, García-Jambrina's novel playfully revels in the stereotypical images that Spaniards hold of Germany and of themselves, as well as in the images Spaniards think the Germans have of Spain. As both novels draw on the stereotypes about the Dutch and the Germans in Spain, they cement a static sense of national identity across time. Irony becomes a relevant strategy in this crisis juncture to mock established stereotypes, particularly in Gullón's and Garcia-Jambrina's novels. Furthermore, Garcia-Jambrina grounds his play with stereotypes about Spain, Germany and the EU in the Spanish literary and cinematic traditions by adopting Valle-Inclán's esperpento

$39 \quad$ Gopegui (2014), p. 58.

40 Gopegui (2014), p. 59. 
or penchant for exaggeration and the grotesque, the anti-hero attitudes of Don Quixote and Lázaro de Tormes, and by taking inspiration from Berlanga's classic film Bienvenido, Mr. Marshall. In the process of alluding to the Spanish literary and cultural canons, cultural memory is mobilised in the creation of patterns of othering and selfhood. Chirbes, Grandes and Gopegui also dwell on historical remembrance and the layered historical assumptions about the Spanish character. Whereas Gullón, García-Jambrina and Chirbes underline for the most part aspects of the Spanish Black Legend, Grandes and Gopegui bring forward the more positive and romantic aspects of the construction of a Spanish identity, highlighting the passion, courage, and struggle against tyranny and oppression. Gopegui and Gullón also add the important element of transnational collaboration and solidarity across social boundaries, questioning the distinction between nationalities and, as a result, the basis for the accretion of the various stereotypes.

Hence, the genre of the novel appears as an important space for reflection on the revival, reshaping and contestation of old stereotypes that offer not just a mirror to the current perception of a divided Europe, but a tool to build up resilience in times of crisis. These novels can be seen as an attempt to constitute a narrative ethics that, on the one hand, may help redefine the notion of European citizenship, and on the other, create meaning and bonds that may reinstate the transnational European ideal emerging after World War II. All in all, these novels convey a sense of social resilience that draws on the unravelling, revision and adaptation of stereotypes that prove themselves to be resilient to the passing of time.

\section{Bibliography}

Bienvenido, Mr. Marshall (1953). Film, dir. by Luis García Berlanga (UNINCI).

Butler, Judith (2004). Precarious Life. The Powers of Mourning and Violence (London:Verso).

Butler, Judith (2009). Frames of War. When Is Life Grievable? (London: Verso).

Chirbes, Rafael (2013). En la orilla (Barcelona: Anagrama). English: On the Edge (2016), trans. by Margaret Jull Costa. (N.Y.: New Directions).

Chirbes, Rafael (2007). Crematorio (Barcelona: Anagrama).

Dadson, Trevor J. (2004) . 'La imagen de España en la Inglaterra de los siglos XVI y XVII' in López de Abiada, López Bernasocchi (eds), Imágenes de España en culturas y literaturas europeas (siglos XVI-XVII) (Madrid: Verbum), pp. 127-175.

Estefanía, Joaquín (2017). Abuelo, ¿cómo habéis consentido esto? Los graves errores que han llevado a la era Trump (Barcelona: Grupo Planeta). 
García-Jambrina, Luis (2015). Bienvenida, Frau Merkel (Madrid: Salto de Página).

Giraldo, Lucena (2006). 'Los estereotipos sobre la imagen de España', Norba. Revista de Historia, 19, pp. 219-229.

Gopegui, Belén (2014). El comité de la noche (Barcelona: Random House).

Grandes, Almudena (2015a). Los besos en el pan (Barcelona: Tusquets).

Grandes, Almudena (2015b). 'When We Were Poor Before', The New York Times, 13 December. http://www.nytimes.com/2013/12/14/opinion/when-we-were-poor-before.html [accessed 02.09.2017].

Gullón, Germán (2013). La codicia de Guillermo de Orange (Barcelona: Destino).

Juderías, Julián (2014). La leyenda negra de España. Reedición del clásico publicado en 1914 (Madrid: La Esfera de los Libros).

Juniper, Tony (2011). 'Will 2012 be the year of the R word?', Guardian, 14 December, https://www. theguardian.com/sustainable-business/resiliance-sustainabledevelopment [accessed 02.09.2017].

Leerssen, Joep (2000). 'The Rhetoric of National Character. A Programmatic Survey', Poetics Today 21, pp. 267-291.

Leerssen, Joep (2007a). 'Imagology. History and Method', in Manfred Beller, Joep Leerssen (eds), Imagology. The cultural construction and literary representation of national characters. A critical survey (Amsterdam, New York: Rodopi), pp. 17-32.

Leerssen, Joep (2007b). 'Image', in Manfred Beller, Joep Leerssen (eds), Imagology. The cultural construction and literary representation of national characters. A critical survey (Amsterdam, New York: Rodopi), pp. 342-345.

Leerssen, Joep (2008). 'Nation and Ethnicity', in Stefan Berger, Chris Lorenz (eds), The Contested Nation. Ethnicity, Class, Religion and Gender in National Histories (Basingstoke: Palgrave Macmillan), pp. $75^{-103}$.

López de Abiada, José Manuel (2007). 'Spaniards', in Manfred Beller, Joep Leerssen (eds), Imagology. The cultural construction and literary representation of national characters. A critical survey (Amsterdam, New York: Rodopi), pp. 242-247.

López de Abiada, José Manuel (2004). 'Teoría y práctica de los estudios imagológicos. Hacia un II de la cuestión', in José Manuel López de Abiada, López Bernasocchi (eds), Imágenes de España en culturas y literaturas europeas (siglos XVI-XV) (Madrid: Editorial Verbum), pp. 13-62.

Orange, William of (1581). 'Apology 'or 'Defense of William of Orange against the ban or edict of the king of Spain'. http://www1.umassd.edu/euro/resources/netherlands/ 24.pdf [accessed 02.09.2017].

Pageaux, Daniel-Henri (1981). 'Une perspective d'études en littérature comparée. L'imagerie culturelle', Synthesis, 8, pp. 169-185.

Tsvetkov, Yanko (2012). Atlas of Prejudice. Mapping Stereotypes, Vol. I (Alphadesigner). Zacharasiewicz, Waldemar (2010). Imagology Revisited (Amsterdam: Rodopi/Brill). 


\title{
Virtually There
}

\author{
Spectral Ireland and European Stereotypes in the Novels of Paul Murray
}

\author{
Aidan O'Malley
}

\begin{abstract}
Paul Murray's three novels, An Evening of Long Goodbyes (2003), Skippy Dies (2010) and The Mark and the Void (2015), constitute a humorous panorama of contemporary Ireland as they chart the ascent and supposed death of the so-called Celtic Tiger. This is an Ireland that has unmoored itself from history and has replaced the dilapidated spiritual authority of the Catholic Church with the guidance offered by the invisible hand of the free market. When this Irish iteration of late neoliberal capitalism failed, the country found itself incapable of imagining any real alternative to it. This contribution illustrates how these novels employ non-Irish European characters to dramatize this process. During the boom years Ireland came to encounter Europe much more directly than before through inward migration, especially from parts of the continent that had not featured in earlier cultural and political constructions of Europe. Murray's novels explore how the stereotyping of European immigrants was essential to the operations of the phantasmagoric Celtic-Tiger Ireland. However, as this essay also shows, the comic exaggerations employed in the satirical representation of this spectral dynamic in Murray's most recent novel gesture back towards, and repeat, the stereotyping the novel is explicitly critiquing.
\end{abstract}

Set in the years of the so-called Celtic Tiger and the subsequent economic crash, Paul Murray's three novels, An Evening of Long Goodbyes (2003), Skippy Dies (2010), and The Mark and the Void (2015) are, in many respects, ghost stories. Charles, the protagonist of An Evening of Long Goodbyes who compares himself to Hamlet, struggles to come to terms with his father's death and tainted legacy; the students in Skippy Dies deal with the trauma of Skippy's unexpected death by constructing a time machine to communicate with him; The Mark and the Void conjures up French thinkers such as Jean Baudrillard and Guy Debord to frame the materialization of zombie banks in the country. Recognisable and comically unreal, the spectral Ireland of these novels is a place in which other-worldly forms of reality are ending. In An Evening of Long Goodbyes Charles is cast out from a salubrious Dublin Garden of Eden, while

(C) AIDAN O'MALLEY, 2021 | DOI:10.1163/9789004436107_015

This is an open access chapter distributed under the terms of the CC BY-NC-ND 4.0 license. 
Skippy Dies charts, amongst other things, the declining spiritual authority of the Catholic Church; unable to compete with the hold that the free market has on the country, these superannuated modes of living are being supplanted by it - a process the novels present as a case of one form of virtual reality replacing another. The illusory nature of this hegemonic economic ideology is the theme of The Mark and the Void, which is set in the immediate aftermath of the 2008 global banking crisis and the collapse of the myth that property prices could only increase. However, as the novel registers, despite this painful unveiling of the chimerical nature of capitalism, it is superseded by an even more unreal version of itself. In short, the Ireland of these novels marks an emptiness that struggles to register a semblance of presence that might transcend the constricted dogma of the unregulated free market.

Skippy Dies (2010)

As is well known, after decades of being the poorest country in Western Europe, the Irish economy took a turn towards unthought-of prosperity in the 199os thanks to a combination of EU funding, a low corporate tax regime, and a well-educated, Anglophone and cheap labour force. Attracted by this, large international corporations, especially from hi-tech sectors such as information technology and pharmaceuticals, pitched up in Ireland. Set in this moment, Murray's most successful novel, Skippy Dies, portrays a country that, as a consequence of this massive economic adrenaline hit, has achieved Stephen Dedalus's ambition of awakening from the "nightmare" of history, and is now wallowing in the daydream of consumerism. ${ }^{1}$ Skippy Dies views the Celtic Tiger years from the perspective granted by an expensive Dublin Catholic boarding school, Seabrook (modelled on Blackrock College, Murray's alma mater), where the students absorb much of the world through the stereotypes that drive fantasy and combat computer games, television shows and films. Under these influences, they relate to the past in a lexicon drawn from the likes of Dungeons and Dragons - invariably referring to history as "days of Yore" - while US films about Vietnam provide the epithets with which they racially abuse the young Chinese man and woman working at their hangout, calling them "Gook", "Gookette" and "Charlie". ${ }^{2}$ But what the novel underlines is that the teenagers' attitudes to the past are confused precisely because most of

1 Joyce (1986), p. 28.

2 Murray (2010), pp. 40-43. 
the adults around them have even less appreciation of history. Many of the younger teachers are, or aspire to be, "kidults", as one of that cohort notes living out of time and as concerned as their students are with the latest shiny gadgets. ${ }^{3}$ The students' parents' emotional lives evince no signs of maturity; all that distinguishes them from the younger generations is the more elevated bracket of consumerism they operate in.

Dealing, as it does, in 'futures' not 'pasts', capitalism is inherently ahistorical, and "[t]he Irish", according to Halley, an American living in the Dublin of this novel, "are all about the future". ${ }^{4}$ George O'Brien has suggested that the characters in this novel "stumble through a mismanaged and fragmented present without the remotest idea of what difference their doing so will make to securing a future." While it is the case that the school, like the society in which it is embedded, is fundamentally lost, it is perhaps more accurate to say that the novel portrays a community that can only imagine finding itself through immersion in the shrunken future promised by the free market.

"There's a little banker inside all of us now", was Murray's diagnosis of the national psyche in a 2015 interview, and Costigan, Seabrook's interim principal, sees it as his job to nurture and spread this virus. ${ }^{6}$ In spite of his excesses, he is less a comic grotesque than an embodiment of the worst aspects of boom-time Ireland: his glib conflation of 'reality' with 'consumerism' regurgitates the shibboleths of politicians and journalists that passed as indisputable wisdom for most of the two decades leading up to the $2008 \mathrm{crash}$. In common with them, Costigan sees himself as a moderniser, especially as he will be the first non-religious principal of the school, which was founded, and has been always been run, by an invented order of priests called the Paracletes. The spirituality of this community is evident in its name: 'paraclete' in Christian theology refers to "the Holy Spirit as advocate or counsellor". ${ }^{7}$ Priests adhering to such a vision of their roles are "outmoded technology" to Costigan's mind: too tied up in the past, and too non-materialistic to prepare the boys for careers in business, which has become the school's raison d'être. ${ }^{8}$ For Costigan, education should be entirely focused on "[r]eality" and "objective, empirical truths." These

\footnotetext{
3 Murray (2010), p. 62.

4 Murray (2010), p. 82.

5 O'Brien (2012), pp. 183 f.

6 Coffey (2015).

7 Oxford English Dictionary. http://www.oed.com/view/Entry/137308?redirectedFrom=paray clete\# eid [accessed 28.10.2017].

8 Murray (2010), p. 94.

9 Murray (2010), p. 93.
} 
are just a couple of the empty platitudes that mould his self-serving debased utopian vision, about which he, notably, daydreams:

although the Paracletes may be gone, for all intents and purposes, their values live on. Maybe the men upholding them will wear a suit and tie instead of a dog collar; maybe they will carry a laptop instead of a Bible, and maybe 'common business model', not 'God', will be the name of the bridge they use to bring communities together. But although appearances may change, the values themselves remain the same - the Seabrook values of faith, decency, various others. ${ }^{10}$

Looking to frame this break with the past in terms of a continuity, this is advertising jargon posing as a credo. History, religion and tradition are not to be jettisoned entirely; rather, they are valued exclusively as unique selling points. They are the intangibles that establish "a strong brand identity", and, as Costigan puts it, "[b]rands rule the world today. People like them. They trust them."11

Importantly, Murray's presentation of this battle for the school's soul is nuanced, and never offers a black-and-white portrait. While the clichéd banality of Costigan's mendacious and ultimately successful project is the main object of this satire, the priests are hardly advanced as a superior alternative. Father Green, a French teacher who has served on the African missions, is the most implacably hostile opponent of Costigan's mercenary programme. The students, though, call him "Père Vert", and his never-fully-articulated dark past points to the brutality and paedophilia that have irredeemably stained the history of the Catholic Church's control of education in Ireland. ${ }^{22}$

The constraints imposed on Ireland by the Catholic Church have now been replaced with those of debt. The pervasiveness of capitalism - how it binds one's affective life to economics - can be witnessed in how Halley tells her partner, Howard, that it is "simple economics" to get a mortgage and set foot on the so-called property ladder. ${ }^{13}$ But, as she is semi-consciously aware, she also views Howard's assumption of this long-term, massive, debt as a sign of commitment to their relationship. Putting a monetary value on their future is an attempt to make it less indefinable, but, as they soon discover, this is a delusion. Michael Hardt and Antonio Negri have traced how the liberty promised by the free market is always a mirage, because it is based on creating a

\footnotetext{
10 Murray (2010), pp. 6o7f.

11 Murray (2010), p. 91.

12 Murray (2010), p. 70.

13 Murray (2010), p. 8o.
} 
population of the "indebted" whose lives have "been put to work". As such, it is an insidious, ubiquitous, system of control:

[b]eing in debt is becoming today the general condition of social life. [...] Your subjectivity is configured on the foundation of debt. You survive by making debts, and you live under the weight of your responsibility for them. Debt controls you. [...] Debt wields a moral power whose primary weapons are responsibility and guilt, which can quickly become objects of obsession. You are responsible for your debts and guilty for the difficulties they create in your life. ${ }^{14}$

Throughout the first decade of the twenty-first century, Irish politicians, commentators and journalists enjoined the country to get itself into as much debt as possible. Fuelled by an unholy alliance of unregulated banks, politicians and developers, Irish property prices sky-rocketed in the years leading up to the 2008 crash. These banks, as L.M. Cullen observed, "broke[] every rule in the canon of banking" with the result that Ireland was, along with Iceland, "the most extreme case of the widespread folly in the world banking system."15 The idea that property values might stop rising - that history had shown that this bubble was unsustainable - had to be clamped down upon and ridiculed, for fear it might puncture the illusion that sustains capitalism: that it can unshackle itself from the past and create an entirely new future simply by repeating the same operations. Notoriously, in 2007 the then Irish Taoiseach, Bertie Ahern, dismissed the economist Morgan Kelly's warnings that the overheated property market would collapse by wondering how he and other commentators who were "sitting on the sidelines, cribbing and moaning", "don't commit suicide". ${ }^{16}$ When the accuracy of Kelly's prognostications became evident just a year later and Ireland underwent the worst economic crash experienced by a developed economy since the Great Depression, the moral power of debt that Hardt and Negri describe was recruited to deflect criticism of the ruinous ideological decisions made by successive Irish governments: when the debts were suddenly called in, neoliberal politicians and

\footnotetext{
14 Hardt, Negri (2012).

15 Cullen (2012), pp. 14f.

16 RTÉ (2007). As can be seen in this news report, Ahern subsequently apologised for taking suicide too lightly, but not for his repudiation of those experts who refused to join in the chorus boosting the economy.
} 
commentators worked to foster the view that blame for the meltdown must also be apportioned to the Irish people for having "partied" too hard. ${ }^{17}$

Before the 2008 crash, the future that these free-market ideologues imagined was most fully embodied in the United States; as Halley notes in Skippy Dies, "an American accent was [...] the Voice of Authority, and anything it said [is] treated as dispatches from the mother ship."18 This reflects the perspective that was most clearly articulated in July 2000 by the then Tànaiste (Deputy Prime Minister) Mary Harney, who claimed that "[g]eographically we are closer to Berlin than Boston. Spiritually we are probably a lot closer to Boston than Berlin." ${ }^{\prime 19}$ On one level, this is merely an Irish brand of the sort of right-wing populism that helped fuel Brexit: favouring the dream of American unregulated neoliberalism over the stereotype of European welfarism (which, in Ireland's case, left it hugely exposed to the US sub-prime mortgage meltdown). ${ }^{20}$ However, phrasing this bias in terms of a spiritual inclination signalled, perhaps unwittingly, a sense of cultural rupture not just with the authority of the Roman Catholic Church, but also with an idea of Europe that played a key role in the development of the bourgeois Ireland Harney would have claimed to represent.

\section{$2 \quad$ An Evening of Long Goodbyes (2003)}

As is most fully articulated in the pages of The Bell journal (1940-54) and in the work of one of its editors, Seán O'Faoláin, many twentieth-century Irish writers and thinkers were disposed to construe an idealised Europe that always already stood in opposition to everything Irish: a place beyond the pulls of nationalism, where rational debate and artistic freedom flourished. Fundamentally existing as a symbol of the secular modernity that Ireland had yet to achieve, this spectral Europe embodied a style that dreary Ireland struggled to emulate, be it in terms of architecture, cuisine, fashion or, simply, a way of life. As such, this vision of Europe played a key aspirational role in the development of middle-class Irish liberalism. Entry into the European Economic Community in 1973, and the increased interactions with European countries

17 For instance, Brian Lenihan, the then Minister for Finance, argued that "we all partied" in a 2010 interview; Lenihan (2010).

18 Murray (2010), p. 82.

19 Harney (2000).

20 As the Nobel laureate economist, Paul Krugman, put it: "How did Ireland get into its current bind? By being just like us [the US, A.O'M.], only more so." Krugman (2009). 
that came with this, did little to disrupt this vision. ${ }^{21}$ Attitudes to Europe only began to change with the advent of Irish prosperity: it was then that proselytizers like Harney began to promote the idea that the country was more properly part of a neoliberal Anglosphere. This coincided with a considerable disruption of the stereotype of Europe: due to the numbers of Central and Eastern European citizens arriving in Ireland, it became increasingly difficult to see Europe exclusively as Western Europe.

European immigrants in Ireland feature prominently in An Evening of Long Goodbyes and The Mark and the Void. Murray's first novel, An Evening of Long Goodbyes, tells the tale of Charles, a wastrel scion of a wealthy Irish family who is drinking his way through the family's cellar. Since his father's death, his mother's hospitalisation for alcoholism and his failed romance with Patsy Olé, he has cocooned himself inside the family estate, away from what he sees as the tainted modern world. He is literally living in a utopia, a no-place that is also a place of happiness: the family house is called Amaurot, which is the capital of Thomas More's Utopia, and his surname, Hythloday, (literally the 'speaker of nonsense') nods to Utopia's Ralph Hythloday, the discoverer of Utopia who refuses to consider being an advisor to the monarch, as such proximity to government would endanger his ideals. ${ }^{22}$ Charles too remains aloof from any form of civic engagement and, initially, very little of Celtic-Tiger Ireland impinges on his consciousness, even if he has heard disturbing tales of the newly-rich circling vulture-like in the vicinity of his demesne: solicitors and bankers in expensive new cars offering fabulous sums for the sort of properties that would grant them a facade of aged respectability. However, his insulation from events beyond his walls is punctured when he discovers that he is a member of the ranks of the indebted: his father purchased Amaurot through an intricate series of dubious mortgages, the payments on which are now so overdue that the banks are threatening foreclosure. Charles devises a hare-brained plan to swindle the family's insurance by exploding a folly he was constructing in the gardens, and when this literally blows up in his face he is cast out from his gilded life.

While the fallen world beyond is harsh, it too seems to operate in a rather fabulous fashion. In particular, Charles discovers that the employment practices that underpin Ireland's booming economy have little contact with the real lives of the workers. Interviewed for a job by the director of a company called 'Sirius Recruitment', Charles is engulfed in the bromides that constitute

\footnotetext{
21 For an overview of the literary constructions of Europe in this period, see O'Malley (2020).

22 Noting that "the telephone company that threatens to buy out Amaurot from the dithering, Hamlet-esque Charles and his Ophelia-like sister is named Telsinor", Stephen Amidon felt that "Murray has a rookie's weakness for literary allusion". Amidon (2004).
} 
the new economy: he would, for instance, not be so much an employee as "a Sirius partner", because, as the director phrases it, "although I'm head of the company, I like to say that I'm working for you."23 These inanities ultimately translate into a job straightening yule logs as they chug along a production line in a bread factory. There was, though, some truth in the director's statements, as it transpires that Charles is not employed by Sirius, "but by its sister company, Pobolny Arbitwo Recruitment." ${ }^{24}$ In fact, he is one of the very few Irish workers on the factory floor: most of the rest are Latvians who are fundamentally indentured to Pobolny Arbitwo, which takes a large percentage of their meagre salaries for having furnished them with a job, and for items such as the barracks-style accommodation it provides. When, without any warning, the workers are told that they are to be laid off and replaced by robots, the everyday chicanery of the arrangement is laid bare: not only do many of the workers discover that, after all the deductions, their final salaries amount to precisely nothing, but they also learn that they are owed no redundancy payment, as they are still employed by the recruitment agency, which was leasing them to the factory. These are the ghosts operating the machinery of Celtic-Tiger Ireland: fabricated companies, nested inside each other like matryoshka dolls, that render the idea of work itself fictitious and grant their immigrant employees little more than a wraithlike existence.

These were not, though, the first immigrants from Central and Eastern Europe that Charles had encountered. In his Edenic persona, he regally described his housekeeper at Amaurot, "Mrs P", as "the help. Bosnian, you know. Or is it Serbian? An absolute treasure, anyway. [...] if there's one good thing to come out of all this fuss in the Balkans, it's the availability of quality staff". ${ }^{25} \mathrm{Mrs} \mathrm{P}$, it is later learnt, had not trained as a cook, but had been a lawyer in Yugoslavia, before the wars there ripped her family apart. She and her family, who are discovered living in the folly that he blew up, came from the Krajina, an area in Croatia bordering Bosnia that had a majority Serb population. And just as Hythloday points to Charles's nonsensical, utopian character, their difficult, "unpronounceable' surname - "Pribicevic" as the novel gives it - signals the end of a dream: Svetozar Pribičević was a politician who campaigned in the first half of the twentieth century for a Serbian and Croatian federal state. Murray, in other words, has given this family a very specific, hybrid, home and identity. Yet, despite these explicit details, everyone in the novel remains hazy about where exactly they are from - having no real knowledge of Yugoslavia

\footnotetext{
23 Murray (2004) p. 223.

24 Murray (2004), p. 255.

25 Murray (2004), p. 6.
} 
and not feeling that it was worthwhile making the effort to know anything about the family's background, they remain exotic Balkan ghosts. Tellingly, this was also true of a number of contemporary reviews of the novel, which seem to have taken Charles (despite his clear fogginess) at his word, and granted the family a Bosnian origin. ${ }^{26}$ While that is inaccurate, it is, at least, geographically proximate; they are bizarrely "Kosovan" in Aisling Foster's Irish Times review. ${ }^{27}$

Although most of the Irish characters absorb this family's history as superficially as they might a piece of horror or fantasy fiction, it strikes one of the more realistic notes in this metafictional comic novel. Amongst other things, the mock-nostalgic take on the advent of the Celtic Tiger in An Evening of Long Goodbyes is a pastiche of Irish 'Big House' literature. The 'Big House' was where the, generally but not exclusively, Anglo-Irish, Protestant ascendancy lived and controlled the lives of the, generally, impoverished Catholic peasant tenants who worked on their estates. 'Big House' literature utilises this potent physical symbol of the historical divides in Irish life, and while this genre has taken different forms, some of the most noted examples of it, such as Yeats's 'Coole Park 1929' and Elizabeth Bowen's novels, have evinced a nostalgic and elegiac vision of a world of culture and civilised living fading away in the face of a rising nationalist, Catholic, philistine middle class. Notably, the Hythlodays' religion or cultural affiliation would appear to be unimportant in Celtic-Tiger Ireland. The novel plays with our assumptions that they are Anglo-Irish and Protestant - Charles dabbled for a year with Theology at Trinity College Dublin, and his manners and attitudes are those associated with the pre-World War II British aristocracy - but this is by no means necessarily the case; his sister, Christabel, for instance, had been educated by nuns. Rather, the Hythlodays are merely aping the 'Big House' affectation of a cultural aloofness from the capitalism that has created the family's wealth.

This mock-aristocratic attitude is given a supplementary Eastern European frame, as Chekhov's The Cherry Orchard is a constant intertextual presence in the novel. Reviewing Frank McGuinness's 1995 version of Uncle Vanya, Irving Wardle noted that "Chekhov over the past 20 years has become an honorary Irish author", ${ }^{28}$ and the novel riffs on the by-now considerable theatrical tradition established by dramatists such as McGuinness, Thomas Kilroy and, most notably, Brian Friel that links Chekhov's world of gentle decline with Irish historical experience. However, despite the fact that the theme of The

\footnotetext{
26 See, for instance, Fennelly (2003); Reyn (2004).

27 Foster (2003).

28 Wardle (1995). Reviewing the same production, John Keyes was driven to capitalise his frustration, declaring that "CHEKHOV IS NOT IRISH". Keyes (1995).
} 
Cherry Orchard - the failure to save an estate - speaks to the family's situation, and that the foregrounding of a classic of Russian literature might be thought to offer an oblique commentary on the ways in which immigrants from this region are stereotyped and treated in contemporary Ireland, Chekhov's drama's primary function in An Evening of Long Goodbyes is to place the world of the novel behind one more lens of fictionality. Everything and everyone in this novel is essentially mimicking or citing something else. If the protagonist's language, with its 'gimlets' and 'Pongos', has been learnt from P.G. Wodehouse, the plot of this novel is more indebted to Evelyn Waugh's laconic unveiling of an Eden's dark underbelly. Importantly, the Irishness of this world is also largely the product of literature: W.B. Yeats's Celtic wistfulness and Oscar Wilde's aristocratic socialism are touchstones in the protagonist's upbringing, and MacGillycuddy, the all-knowing, if not entirely reliable, postman who organises fake deaths and new lives, has stepped from the pages of a Flann O'Brien novel (The Third Postman perhaps?). In short, the novel constantly vaunts its virtuality, the fact that it is all made up: although Charles likes to pretend that the family's wealth is an aristocratic inheritance, it actually derives from his father's skill in concocting cosmetics - the whole edifice is literally built on makeup.

"Idea for a novel" are the first words of The Mark and the Void, which is yet more emphatically a metafictional novel, even if it is peculiarly uncomfortable in that skin. ${ }^{29}$ It surveys the causes of Ireland's economic collapse and, to a lesser degree, the wreckage it wrought, from the perspective of Claude Martingale, a Frenchman working in what he terms "shadow-banking" in the "shadow-place" that is Dublin's International Financial Services Centre (IFSC). ${ }^{30}$ Citing François Texier, the fictional French philosopher whose non-presence lies at the heart of this novel, Claude describes the IFSC as an archetypal virtual location: it is "real without being actual, present without being there". ${ }^{31}$ For Paul, a writer whose surname we never learn, the international anonymity of the IFSC - the fact that it could be anywhere and so "[b]eing here means not being here" - renders it the quintessential location of "modern life". 32 Inhabiting this liminal non-place makes Claude a prototypical twenty-first-century

\footnotetext{
29 Murray (2016), p. 1.

$30 \quad$ Murray (2016), p. 23.

31 Murray (2016), p. 23.

$32 \quad$ Murray (2016), p. 15.
} 
Leopold Bloom, a contemporary Dublin Everyman. For this reason, Paul wants to model his next novel on Claude, and proposes shadowing him for a period to deepen his understanding of his life and work. But, as the reader knows from the second half of the novel's first sentence - "we have a banker rob his own bank" - these literary intentions are simply window-dressing for a scam to infiltrate and steal from Claude's bank. ${ }^{33}$ Paul's preposterous plan comes to nought because, as Claude points out to him, the bank has no actual, tangible, money on its premises; just as Paul's heist is based on nothing more than a never-to-be novel, the substance of this bank is virtual, merely numbers flashing on computer screens.

The intersection of business and aesthetics is a theme that runs through these three novels. Skippy Dies traces how, by stripping away values that might sustain art, a business culture delivers a world in which the quality of a piece of classical music is evaluated from its use in a Citroën car advertisement. An Evening of Long Goodbyes takes a sardonic look at a would-be alternative and socially-concerned theatre troupe and its ready embrace of sponsorship from a large telecommunications corporation that thinks having a little 'edge' might be beneficial to its image - a union that is greatly facilitated by their shared fluency in vacuous non-speech. In The Mark and the Void Claude's colleagues are surprisingly excited to have a novelist take an interest in their lives: faced with the virtuality and dullness of their work, they look to fiction to offer narratives that might make sense of their condition. Indeed, these bankers are some of the few characters in the novel who have any conviction about the usefulness of art and literature.

More generally, a deep disillusionment with literature can be detected in The Mark and the Void, a novel full of writers losing faith with writing. After his first book failed to launch him into literary stardom and its attendant financial advantages, Paul's days are now spent either in lap-dancing clubs or concocting bizarre schemes for making a quick buck. In contrast, the literary sensation du jour, Bimal Banerjee, declares his intention to retreat from the world of letters in order to place himself beyond the reach of the marketplace. Disenchanted with philosophy, Texier turned to painting, and even though he refused to sell his paintings, they nonetheless made their way into the market, causing him to give up that art form as well. One of his most famous pieces, Le Marque et le Vide, 'The Mark and the Void', ends up on the wall of a successful Irish writer and his banker partner in Dublin. It is described as: "[w]ords upon words upon yet more words; hundreds of 
pages of text superimposed one on top of the other, rendering each other utterly illegible - creating instead a cascading darkness that seems to devour the very possibility of meaning." ${ }^{34}$ In a not entirely dissimilar fashion, the palimpsestic, metafictional form of The Mark and the Void stresses its spectral nature: this is a novel that, in a deliberately perverse way, appears to be struggling to unwrite itself as it unfolds.

This disquiet about the meaning of literature largely stems from the novel's insecurities about the necessity and possibility of fiction writers articulating the operations of international finance. As this sector is fundamental to so much of contemporary life, the novel constantly argues for a fictional engagement with it. Yet, in the same moment, it raises doubts about the ability of fiction to communicate the hegemonic, incoherent, meaninglessness of the make-believe world of the free market; a universe where, for instance, the apparently huge wealth that was generated in the years of the Celtic Tiger could seemingly disappear overnight: "[ $t$ ]he banking crisis", in Banerjee's succinct terms, "is unrepresentable". ${ }^{35}$ Nonetheless, a considerable amount of The Mark and the Void is devoted to unveiling and explaining the magical thinking that characterises contemporary finance. In fact, as the novel's fictional philosopher, Texier, points out, businesses have an essentially mythical basis:

what we call the corporation [...] first appeared in Europe's Middle Ages, signed into law by the Pope in AD 1250. It was conceived as a legal persona ficta - a 'fictive person' that had many of the attributes of a real person. It was capable of owning property, for example, of suing and being sued; at the same time, it was bodiless, invisible, free from human infirmity and the ravages of time. Conceived as such, the corporation was almost identical to contemporary ideas of angels. [...] the corporation, an entity which we imagine as a uniquely secular creation, a paragon of reason and common sense, in fact began its life as an offshoot of a Christian myth. ${ }^{36}$

The priesthood who keep this flame alive is composed, for the most part, of young male bankers who are so immersed in the angelic, virtual, ever-present they cannot determine their desires for corporeal women until they have photographed them on their phones. History is only relevant to the extent that it presents them with a challenge to make more money for themselves and their fabulously wealthy clients in the future.

\footnotetext{
$34 \quad$ Murray (2016), p. 328.

35 Murray (2016), p. 331.

$36 \quad$ Murray (2016), p. 265.
} 
This arrogant ahistoricism is dictating the direction of Claude's employers, the Bank of Torabundo, an investment bank that has survived the financial crisis thanks to the conservative approach of its CEO, Sir Colin, who avoided "toxic investments" as he "was deeply suspicious of complex derivatives". ${ }^{37}$ Surrounded by the wreckage of failed competitors, this prudence has transformed Torabundo into an important player, and it seeks to build on this standing by sacking Sir Colin and replacing him with Porter Blankly. He is spoken of as a financial demigod both by the bankers and by the financial press despite having been the guiding light at Danforth Blaue, "one of the biggest casualties of the crash" that "needed a fifty-billion rescue package from the US government". ${ }^{38}$ Living up to his name, the always off-stage Blankly issues occasional gnomic emails to his employees, who regard them as Delphic riddles they must decipher. In brief, he occupies the higher echelons of the seemingly untouchable pantheon of contemporary alchemists who seek to turn corporate and national losses into profits for themselves and their wealth-fund clients. ${ }^{39}$ Claude, who does not entirely buy into this esoteric thinking, discovers how it operates when he is given the prestigious task of preparing a report for the Irish government on the largest failing bank in the country, the Royal Irish Bank. As he quickly realises, this is a completely unsustainable entity that never had any substance at the heart of its labyrinthine, fictional, accounts. However, his report advising that the bank get no more public money and be shut down is not what the government or his bank wanted to hear: their priority is to protect the bank's wealthy international bondholders, which entails keeping the money flowing. Claude's report is redacted, and the government presents it as an endorsement of its policy of pretending this persona ficta were alive. Thus, rather than as a result of inscrutable theorems devised by the enigmatic Russian mathematicians the bank employs, this contemporary financial alchemical process is revealed to work in a much more mundane fashion: through massive misappropriations of public money this so-called zombie bank continues to generate profits for the super-rich.

Scandalously, this happened in Ireland on 29 September 2008, when the government decided to provide a 100\% guarantee for the "deposits and debts"

\footnotetext{
37 Murray (2016), p. 40.

$38 \quad$ Murray (2016), p. 41.

39 According to Murray, these characters are more congenial than real bankers: his research revealed " $t]$ he preposterous machinations of these people who we still think of as being sane and sober individuals. But they're not. They're basket cases [mad, A.O'M.]. The banks were full of basket cases, people who had lost any connection to their responsibilities as human beings." Wallace (2015).
} 
of Ireland's embattled banks, the most insolvent of which was Anglo-Irish Bank, which had been named the world's best bank in 2006 by the still highly-reputed international consultancy firm, Oliver Wyman. ${ }^{40}$ Agreed to by the then Minister for Finance, Brian Lenihan, this guarantee, as Fintan O'Toole put it, maintained "the fiction that [Anglo-Irish] was a viable bank" by making Irish tax-payers responsible for all its debts. ${ }^{41}$ Like other noisy champions of deregulated banking, Seán FitzPatrick, who had helmed Anglo-Irish into these rocks, turned to public money when the invisible hand of the market proved to be precisely non-existent. Identifiable versions of these events and characters are to be found in The Mark and the Void, and if it might seem "unfair, even imprudent to write of a dying, and potentially recognisable, minister for finance", ${ }^{42}$ as Eileen Battersby put it in her notoriously scathing review of this novel, it is also the case, more generally, that the representations of the personae fictae in this book are marked, in different ways, by a problematic shifting equilibrium between the realistic and the spectral.

If the masks fabricated here for some of the principle actors in Ireland's actual crash are deliberately transparent, the fictionality of many of the other characters in this novel is accentuated. As in The Evening of Long Goodbyes, one way this artificiality is emphasised is through their names. Claude's surname, Martingale, wryly points both to his understated character, as it signifies "a strap or set of straps [...] used to prevent the horse from raising its head too high", and to the fiction underlying his profession: it also names "a gambling system of continually doubling the stakes in the hope of an eventual win that must yield a net profit."43

Other characters in this novel, though, manifest a more troubling form of virtual reality. The epigraph for section three of The Mark and the Void is the opening sentence of Guy Debord's 1967 Society of the Spectacle, which, in many respects, sets the scene for the world of this novel: "[i]n societies where modern conditions of production prevail, all of life presents itself as an immense accumulation of spectacles. Everything that was directly lived has moved away into a representation." 44 Stereotyping, which offers a debased, fictionalised, rendition of lived reality, provides a vocabulary for many of the characters in

\footnotetext{
40 Murray-Brown, Dennis (2008). While this report has vanished from Oliver Wyman's site, a copy can be found at Cotterill (2011).

41 O'Toole (2010), p. 208.

42 Battersby (2015).

43 Oxford English Dictionary. http://www.oed.com/view/Entry/114453?rskey=4Z4brH\&reE sult=1\#eid [accessed 28.10.2017].

Murray (2016), p. 263.
} 
this novel and, thanks to the toxic masculinity that drives both places, communication in the offices of Torabundo frequently echoes that which might be heard in the schoolyards of Skippy Dies. Claude is known as the "Crazy Frog" to his colleagues, ${ }^{45}$ and the fiction of national stereotyping appears to be a way in which these deracinated bankers try to ground each other and negotiate their bewildering virtual world. More importantly, the novel further suggests that this recourse to crude stereotypes plays a guiding role in the policies of these institutions. As he dispassionately explains the massive Ponzi swindle that his bank has perpetuated by getting the Irish public to shoulder its debts, Jurgen has no doubt that the Irish will take this calmly, as they "are at root a slave race" that "until very recently [had been] ruled by priests" and, as a result, "believe they are born in debt". ${ }^{46}$ Just as the profits generated by the Celtic Tiger were indisputably international while the losses became entirely Irish, this German character illustrates how global capitalism is only superficially post-national.

Nowhere, though, is this more apparent than in the treatment of the Eastern European characters in The Mark and the Void. If, as Jurgen indicates, Ireland is now viewed as a subordinate European nation (one that is far from indulging in fantastical debates about which side of the Atlantic it belongs to), the novel constantly marginalises characters from the post-communist flank of the continent. At the periphery of the narrative we find mad Russian geniuses who live in cupboards, Bulgarian drug dealers, and "gaunt Slavs with chilly eyes". ${ }^{47}$ Igor and Clizia, the two most important Eastern European characters, are nothing more than stereotypes. Igor is a servile, grotesque heavy, who cannot even bear to look at the art on display in a café. And while Clizia is imbued with considerably more dignity, she is ultimately a cipher: named after the nymph who transformed herself into a sunflower after the sun had rejected her, she is never anything more than a lap dancer and Paul's long-suffering, loyal, wife. Crucially, she is from nowhere; or, rather, from an entirely invented state. Clizia, as Paul explains, is from "Ectovia. Used to be part of Makhtovia, then when Transvolga seceded from Makhtovia it became a subdistrict of Transvolga. Then it seceded from Transvolga, to become the Ectovian Free Democratic Republic." 48 While Transvolga exists as a region, neither Ectovia (which

\footnotetext{
45 Murray (2010), p. $26 f$.

46 Murray (2016), p. 443.

47 Murray (2016), p. 246.

48 Murray (2016), p. 167. Although he is by far the more irredeemably stereotyped character, Igor is given an actual homeland. Reminiscing about his wife, yet again a stripper, who "must be fifteen now", Igor reveals that he comes from the "Transnistrian Autonomous
} 
perhaps plays on the German echt 'authentic') nor Makhtovia (the German for power is Macht) can be located. ${ }^{49}$

Vesna Goldsworthy has documented how British popular fiction writers in the nineteenth and twentieth centuries regularly invented Balkan countries such as Ruritania to grant their tales an exotic, decidedly other and politically volatile, locale: "[a]mid the general embourgeoisement which [...] made most of Europe appear too dull for romance, only the Balkans seemed to escape the 'intrusion of civilised monotony', as H.H. Munro (Saki) [put it]". ${ }^{50}$ Through a reading of Malcolm Bradbury's Rates of Exchange (1983), Kazuo Ishiguro's The Unconsoled (1995) and Jim Crace's Six (2003), Hywel Dix's updated supplement to Goldsworthy's study found that while "the end of the Cold War, the expansion of a global economy and the prospect of an expanded European Union might have been expected to be accompanied by a shift in discursive representations of the cultures and societies of Eastern Europe", this has not happened. ${ }^{51}$ Instead of "addressing the specificities of actually existing Eastern European societies", these novels present "a series of Eastern European societies that are emptied of content".52 In conspicuous contrast to the rendering of the Pribičević family in The Evening of Long Goodbyes, Clizia's fictional background serves as nothing more than a stereotype of the worst excesses of the supposedly unimaginable (to a Western European) ethnic fragmentation of the post-communist world. It casually describes a history that has brought about a set of literally meaningless states, presumably concocted from the stereotypical Eastern European propensity to reanimate ancient nationalisms, religious divides or other forms of authoritarianism. In other words, Clizia's virtual homeland represents the belated forms of experience that Ireland - which has regularly been thought to have shared a history of 'ethnic nationalism' with Eastern Europe - has left in its wake in its journey towards the impalpability of the free market. ${ }^{53}$ No doubt The Mark and the Void wants

Region" in the "former Soviet Union" - a disputed area in Moldova between Ukraine and the Dniester river. (p. 26o).

49 Echoes might perhaps also be heard of Makhnovia, a stateless 'Free Territory' that sought to function as an anarchist society from 1918-21 in present-day Ukraine.

$50 \quad$ Goldsworthy (1998), p. 43.

$5^{1} \quad$ Dix (2015), p. 989 .

$5^{2} \quad$ Dix (2015), p. 989.

53 Hans Kohn, for instance, offered an influential, geographically-defined distinction between civic and ethnic nationalisms: if Western European nationalism was cast as civic, its Eastern counterpart was ethnic. This neat metaphorical arrangement was somewhat disrupted by the fact that Ireland was assigned to the ethnic camp. See Kohn (1945), pp. 329-34. 
to portray Clizia and the other Eastern European immigrants as the ultimate victims or embodiments of what Debord called the "[s]pectacular power" of global capitalism. ${ }^{54}$ However, their extremely stereotypical configurations not only frustrate this ambition, but also ineluctably throw into counterintuitively positive relief the chimeras of embourgeoisement and free-market stability in a crisis-ridden Ireland.

\section{Bibliography}

Amidon, Stephen (2004). 'An Evening of Long Goodbyes. This Man Is an Island', New York Times, 5 September. http://www.nytimes.com/2004/o9/o5/books/review/ an-evening-of-long-goodbyes-this-man-is-an-island.html [accessed 28.10.2017].

Battersby, Eileen (2015). 'The Mark and the Void, by Paul Murray. Review', Irish Times, 11 July. https://www.irishtimes.com/culture/books/the-mark-and-the-void-by-paulmurray-review-1.2277627 [accessed 28.10.2017].

Coffey, Edel (2015).“"There's a little banker in all of us”-Writer Paul Murray', Irish Independent, 22 July. https://www.independent.ie/entertainment/books/theres-a-littlebanker-in-all-of-us-writer-paul-murray-31390674.html [accessed 28.10.2017].

Cotterill, Joseph (2011). 'World's Best Bank (2006 Vintage)', Financial Times, 11 September. https://ftalphaville.ft.com/2011/02/11/485311/worlds-best-bank-20o6-vintage/ [accessed 28.10.2017].

Cullen, Loius M. (2012). 'Bankers, Bureaucrats, Booms and Bust', The Irish Review, 45 (Autumn), pp. 1-18.

Debord, Guy (1998). Comments on the Society of the Spectacle. (London, New York: Verso).

Dix, Hywel (2015). 'On Balkanism and Orientalism. Undifferentiated Patterns of Perception in Literary and Critical Representations of Eastern Europe', Textual Practice, 29.5, pp. 973-91.

Fennelly, Amanda (2003). 'An Evening of Long Goodbyes by Paul Murray', RTE.ie, 16 June. https://www.rte.ie/entertainment/book-reviews/2003/o616/445522-murrayp/ [accessed 27.10.2017].

Foster, Aisling (2010). 'Plot Lost in Flawed Fogey Farce', The Irish Times, 10 May. www.irishtimes.com/news/plot-lost-in-flawed-fogey-farce-1.358548 [accessed 27.10.2017].

Goldsworthy, Vesna (1998). Inventing Ruritania. The Imperialism of the Imagination (New Haven, London: Yale University Press).

54 Debord (1998), p. 6. 
Hardt, Michael, Antonio Negri (2012). Declaration. https://antonionegriinenglish. files.wordpress.com/2012/05/93152857-hardt-negri-declaration-2012.pdf [accessed 28.10.2017].

Harney, Mary (2000). Remarks by Tánaiste Mary Harney at a Meeting of the American Bar Association in the Law Society of Ireland, Blackhall Place, Dublin on Friday 21 July 2000. https://archive.fo/CRrS3 [accessed 01.11.2017].

Joyce, James (1986). Ulysses [The Corrected Text]. (London: Penguin Books).

Keyes, John (1995). 'Nothing Twice', Fortnight, March, p. 40.

Kohn, Hans (1945). The Idea of Nationalism. A Study of Its Origins and Background (New York: The Macmillan Company).

Krugman, Paul (2009). 'Erin Go Broke', The New York Times, 19 April. http://www.nytimes.com/2009/o4/20/opinion/2okrugman.html [accessed 01.11.2017].

Lenihan, Brian (2010).'We All Partied', Prime Time RTE Television, 24 October. https://youtu.be/YK7w6fXoYxo [accessed o1.11.2017].

Murray, Paul (2004). An Evening of Long Goodbyes (London: Penguin Books).

Murray, Paul (2010). Skippy Dies (London: Penguin Books).

Murray, Paul (2016). The Mark and the Void (London: Penguin Books).

Murray-Brown, John, Neil Dennis (2008). 'Ireland Guarantees Six Banks' Deposits', Financial Times, 30 September. https://www.ft.com/content/2124f8f4-8eb9-11dd946c-oooo779fd18c [accessed o1.11.2017].

O'Brien, George (2012). The Irish Novel, 1960-2010 (Cork: Cork University Press).

O’Malley, Aidan (2020). 'Irish Writers and Europe,' in Eve Patten (ed.), Irish Literature in Transition, 1940-1980 (Cambridge: Cambridge University Press), pp. 66-82.

O’Toole, Fintan (2010). Ship of Fools. How Stupidity and Corruption Sank the Celtic Tiger (London: Faber and Faber).

Reyn, Irina (2004). 'Living as an Art Form while Losing a Fortune', San Francisco Chronicle, 5 September. http://www.sfgate.com/books/article/Living-as-an-art-formwhile-losing-a-fortune-2695667.php [accessed 28.10.2017].

RTÉ (2007). 'Ahern Apologises for Suicide Remark', RTE.ie, 4 July. https:/www.rte.ie/ news/2007/0704/90808-economy/ [accessed 28.10.2017].

Wallace, Aminta (2015). 'Paul Murray, "The banks were full of basket cases"', The Irish Times, 18 July. https://www.irishtimes.com/culture/books/paul-murray-the-bankswere-full-of-basket-cases-1.2287206 [accessed 28.10.2017].

Wardle, Irving (1995). 'Dandy, but not quite fine', Independent on Sunday, 26 February. 


\section{Index of Names}

\begin{tabular}{|c|c|}
\hline Abelard, Peter 130 & Billig, Michael $\quad 2,105,212$ \\
\hline Adamkus, Valdas $\quad 39,40,41$ & Bismarck, Otto von 20 \\
\hline Adorno, Theodor 96 & Bitnički, Fran 168n34 \\
\hline Adrian VI, Pope $\quad 166 \mathrm{n} 25$ & Blair, Tony 67 \\
\hline Agamben, Giorgio 139 & Blažević, Zrinka $\quad$ IX, 8, 16o-171 \\
\hline Ahern, Bertie $\quad 271$ & Blumenbach, Johann Friedrich $\quad 127$ \\
\hline Ai, Weiwei 86 & Blumenberg, Hans $\quad 136,162,163 n 9$ \\
\hline Akin, Fatih 192 & Bolingbroke, Henry, Duke of Hereford \\
\hline Alexander, Jeffrey 112 & 62,63 \\
\hline Alexander, the Great 129 & Bornschier, Simon 78 \\
\hline Ali Suavi 150 & Bos, Linda 111 \\
\hline Allen, Woody 147 & Bottici, Chiara $\quad 162,163,164$ \\
\hline Almodóvar, Pedro $\quad 251$ & Bourdieu, Pierre 100 \\
\hline Ambrulevičiūtè, Aelita $\quad$ IX, $6,31-46$ & Bowen, Elizabeth 275 \\
\hline Amidon, Stephen $\quad 273 n 22$ & Bradbury, Malcolm 282 \\
\hline Anderson, Benedict 98 & Brandt, Margareta 224 \\
\hline Aquinas, Thomas 130 & Breinersdorfer, Fred 190,191 \\
\hline Aristobulus, of Alexandria $\quad 148$ & Brubaker, Rogers 77 \\
\hline Aristotle $\quad 136 \mathrm{n} 19$ & Brug, Wouter van der 111 \\
\hline Arminius, Prince of the Cherusci & Bruns, Julian 79 \\
\hline Attila, the Hun 86,129 & Budina, Samuel $\quad 166 \mathrm{n} 28$ \\
\hline Augustine, of Hippo 126 & Bumblauskas, Alfredas 41 \\
\hline Azeglio, Massimo d' $\quad$ 16nı & \\
\hline & Caesar, Julius $\quad 128,129$ \\
\hline Bach, Johann Sebastian 128 & Caimotto, Maria Cristina 211 \\
\hline Bacon, Roger 130 & Calatrava, Santiago $\quad 251$ \\
\hline Badalić, Hugo $170 n_{42}$ & Calhoun, Craig 77 \\
\hline Barkhoff, Jürgen $\quad \mathrm{X}, 1,1-11$ & Cameron, David 53 \\
\hline Barnier, Michel 127 & Carathéodory, Constantin 148 \\
\hline Barthes, Roland 194 & Carey, Daniel $\quad \mathrm{x}, 6,7,5^{1-68}$ \\
\hline Battersby, Eileen $\quad 280$ & Carlyle, Thomas 21 \\
\hline Baudrillard, Jean $\quad 267$ & Casas, Bartolomé de las 250 \\
\hline Baur, Rupprecht 223 & Castoriadis, Cornelius $\quad 162,164$ \\
\hline Becker, Lars $\quad 181,182,186$ & Catherine, of Valois 63 \\
\hline Beller, Manfred $\quad$ XI, 126 & Catherine II, Empress of Russia \\
\hline Benoist, Alain $\quad 84,85,86$ & Černý, David 89,90 \\
\hline Beresnevičius, Gintaras $\quad 32,34-38,41$ & Chekhov, Anton $\quad 275,276$ \\
\hline Berger, Stefan $\quad 6,15,15^{-27}$ & Chirbes, Rafael $\quad 247,248,249,256,257,25^{8}$, \\
\hline Bergman, Ingmar 128 & 259,26 o, 261, 265 \\
\hline Berlanga, Luis García $\quad 254,265$ & Churchill, Winston $51,66,67,68$ \\
\hline Berlusconi, Silvio 212 & Coenen, Lily $\quad 207$ \\
\hline Bernard, of Clairvaux $\quad 165$ & Cohen, Hermann 148 \\
\hline Bever, Maarten van 212 & Coles, Robert 78 \\
\hline Beverlander, Pieter $\quad$ XIII & Colley, Linda 68 \\
\hline Bigas Luna, José Juan $\quad 26$ on $32_{2}$ & Conze, Werner 22 \\
\hline
\end{tabular}


Cook, James 126

Cooper, Frederick 77

Copernicus, Nicolaus 131

Cortés, Hernán 211

Cottret, Bernard $53 n_{4}$

Crace, Jim 282

Črnko, Ferenc 166n28

Cullen, Louis M. 271

Cyril, Saint $\quad$ 167, 168n35

Dąbrowska, Jarochna 223

Dai, Jia 208, 213

Dante Alighieri $170 \mathrm{n}_{41}$

Davies, Norman 45

Dawson, William Harbutt $\quad 20,21$

Debord, Guy $\quad 267,28 \circ, 283$

Defoe, Daniel $\quad 6,51,52,57,58,63$

Delanty, Gerard XIII, 96

Demeter, Dimitrije $\quad 167 n 29$

Depardieu, Gérard $\quad 127$

Derrida, Jacques 126

Descartes, René 84

Devlin, Bernadette 127

Diderot, Denis 131

Dijk, Teun van 223

Dix, Hywel 282

Donelaitis, Kristijonas 42

Doorslaer, Luc van $\quad \mathrm{x}, 8,205^{-218}$

Edward III, King of England $\quad 61 n 29$

Einstein, Albert 148

Eliade, Mircea 8

Elizabeth I, Queen of England 54

Enya 127

Epicurus 148

Erasmus, Desiderius 126

Erdoğan, Recep Tayyip $\quad$ 142, 143, 149, 214

Estefanía, Joaquín 26in34

Europa 129

Farage, Nigel $\quad 5^{8}$

Fawkes, Guy 81

Faye, Guillaume $\quad 84,87$

Ferdinand I, Holy Roman Emperor $\quad$ 165n23

Filmer, Denise 211

FitzPatrick, Seán 280

Flood, Christopher G. 163

Folkerts, Ulrike $188 n_{5}$ o

Forchtner, Bernard $\quad$ XIII, 111
Foster, Aisling 275

Fowler, Corinne $\quad 206,207$

Foxe, John 250

Fraile-Marcos, Ana María $\quad$ X, 9, 10, 247-265

Franco, Francisco $\quad$ 25o, 258n26

Frankopan, Bernardin $\quad 166$

Frankopan, Krsto 166

Freud, Sigmund 147

Friel, Brian 275

Fritzsche, Peter 18

Galilei, Galileo $\quad$ 131, 17on41

Gambier, Yves $\mathrm{x}$

García-Jambrina, Luis $\quad 247,248$

Garibaldi, Giuseppe $\quad 15,16$

Gediminas, Grand Duke of Lithuania $\quad 41$

Geis, Michael 224

Genevieve, Saint $\quad 81,86$

Genghis Khan 129

George, Götz $183 n 26$

Giolitti, Giovanni 16

Giraldus, Cambrensis 137

Glösel, Kathrin 79

Göckeritz, Harald 187

Gökalp, Ziya $\quad$ 150, 151

Goldsworthy, Vesna 282

Gopegui, Belén $\quad 247,249,263,264,265$

Grabe, Hans-Dieter 192

Graf, Martin $\quad 112 n 64$

Gramsci, Antonio $\quad 7,87$

Grandes, Almudena $\quad 247,249,260,261,262$, $263,264,265$

Greenland, Katy 17

Griffin, Roger 101

Grix, Jonathan 214

Guardiola, Pep 212

Gudenus, Johann 108, 109, 114

Gülich, Elisabeth 224

Gullón, Germán $\quad 247,248,251,252,253,254$, $256,256,261,264,265$

Haider, Jörg $\quad$ 108, 112, 113

Hakluyt, Richard $\mathrm{x}$

Halbwachs, Maurice $\quad 98$

Hall, Stuart 99

Hardt, Michael 270, 271

Harney, Mary 272, 273

Heer, Hannes XIII

Henry v, King of England $\quad 63,64$ 
Henry viII, King of England

Heraclitus, of Ephesus 136

Herodotus 128, 129

Hesiod 128

Hestia 135

Hitler, Adolf 148, 215

Hobsbawm, Eric 78

Hofer, Norbert 109

Hoskins, Andrew 177

Howanietz, Michael 109

Isaiah $\quad 165$

Ishiguro, Kazuo $\quad 282$

Jambrina, Luis García $\quad$ 254, 255, 256, 264, 265

James I, King of England 53

James II, King of England $\quad 56$

Janus 136

Januška, Albinas 39

John, Duke of Brabant $61 n 29$

John, of Gaunt, Duke of Lancaster 61

John Paul II, Pope 168n35

Johnson, Boris 51, 66

Jones, Paul XIII

Jordan, Constance 65

Joyce, James 58

Judas Iscariot 109

Juderías, Julián 250

Juray iv, Zrinski 166n28

Kafka, Franz 147, 209

Kahn, Charles H. $\quad$ 136n21

Kansteiner, Wulf $\quad$ XI, 9, 175-198

Kant, Immanuel 148

Kasumba, Florence 186

Katsuaki Kozai $170 \mathrm{n}^{2}$

Katz, Jack 186

Kelly, Morgan 271

Kickl, Herbert 114

Kilroy, Thomas 275

Klüger, Ruth 192

Knights, Mark 27

Kohn, Hans $\quad$ 282n53

Konstantinavičiūtė, Gintė IX

Korais, Adamantios 146

Kreisky, Bruno 107

Krugman, Paul 272n2O

Krzyżanowski, Michał XIII

Kurz, Sebastian $\quad 7,110,116,117$

$53,54,55$
Kwaśniewski, Aleksander 40

Laamiri, Mohammed 222

Lacroix, Chantal 214

Lang, Peter XII

Lasorsa, Dominic $\quad 208,213$

Laurinkus, Mečys 39

Le, Elisabeth $\quad 206 \mathrm{n} 3$

Le Pen, Marine 80

Leerssen, Joep $\quad$ XI, 1, 1-11, 3, 125-139, 206, 217, $218,248 n 3,251$

Lenihan, Brian $\quad 272 n 17$

Leo Africanus 129, 13 o

Leo $\mathrm{x}$, Pope 165

Lévi-Strauss, Claude 147

Lindgren, Astrid 128

Link, Jürgen 194

Liubartas, Grand Prince of Volhynia 41

Locke, John 84

Lopata, Raimundas 39, 40, 42

Lucena Giraldo, Manuel 249

Ludwig, Emil 20

Lukas, Filip 168n34

Lukashenko, Alexander 45

Luther, Martin 76, 131, 255

Mahmut II, Sultan of the Turks 149

Mahnič, Antun 168n34

Major, John 67

Manoschek, Walter XIII

Marina, La Malinche 211

Marković, Franjo 17on42

Martel, Charles $\quad 79,130$

Marx, Karl $\quad$ 136n19, 147, 148

Mary, Princess Royal of England $\quad 56$

Mary I, Queen of England 54

Mason, Roger $\quad 53 \mathrm{n} 2$

Maximilian I Holy Roman Emperor $\quad$ 165n23

May, Theresa $\quad 5^{1}$

McGuinness, Frank 275

Mehmet II, Sultan of the Turks 130, $15^{2}$

Meinecke, Friedrich 21

Merkel, Angela $\quad$ 9o, 192, 215, 254, 255

Metallinos, Georgios 146, 147

Methodius, Saint $167,168 \mathrm{n} 35$

Millas, Hercules (Iraklis) XI, 7, 8, 142-156

Moliére $170 n 41$

Montesquieu, Charles de Secondat, baron de 131 
More, Thomas, Saint $\quad 273$

Moses 148

Mowbray, Thomas, Duke of Norfolk $\quad 61,62$

Munro, H.H. (Saki) 282

Murray, Paul $\quad$ 9, 10, 267-270, 273, 274, 279n39

Murray-Brown, Dennis $\quad 280 n_{40}$

Musolff, Andreas $\quad 115$

Mussolin, Benito $\quad 126$

Nabokov, Vladimir 126

Namık Kemal 150

Napoleon I, Emperor of the French $132 n 10$

Negri, Antonio $\quad$ 270, 271

Newton, Isaac 131

Niger, Thomas 165

Nikola IV, Zrinski $\quad 166,169,170$

Nikola VII, Zrinski $\quad$ 166n28

Noah 129

Nora, Pierre 91

Norkus, Zenonas $\quad$ XI, 6, 31-46

Notker, the Stammerer 129

O'Brien, Flann $\quad 276$

O'Brien, George $\quad 267$

O'Connell, Daniel 67

Odysseus 129

Oetzmann, Jobst 190, 191

O’Faoláin, Seán $\quad 272$

O'Malley, Aidan $\quad$ XII, 10, 267-283

Orbán, Viktor 117

Ortner, Christina 194

Ossenberg, Stefan 223

O'Toole, Fintan $\quad$ 52n1, 28o

Ouasti, Boussif 222

Paksas, Rolandas 39

Patten, Eve XII

Paulauskas, Artūras 39

Pavlopoulos, Prokopis 142

Pedro I, King of Castile and León $\quad 61 n 29$

Petar IV, Zrinski $\quad$ 166n28

Peter, Friedrich 107

Petersen, Wolfgang $\quad 183 n 28$

Petljura, Symon $\quad 25$

Petri, Wolfgang 22

Philip II, King of Spain 54

Philip II, King of Spain and Portugal $\quad 252$

Philippa, of Hainault $\quad 61 n 29$
Piccolomini, Enea Silvio 130

Piccolomini, Enea Silvio (Pius II, Pope) 130

Piłsudski, Józef 45

Pirenne, Henri 25

Pius II, Pope (Piccolomini, Enea Silvio) 137

Plato 148

Pollak, Alexander XIII

Polo, Marco 131

Ponzi, Charles $\quad 281$

Pribićević, Svetozar 274

Prieto, Raúl Sánchez XII, 9, 221-241

Pümpel-Mader, Maria 223

Quiquerez, Ferdinand $\quad$ 17on41

Rački, Franjo $167 \mathrm{n}_{32}$

Rafael $170 \mathrm{n}_{41}$

Rajoy, Mariano 248

Rákóczi, Francis II, Prince of

Transylvania 19

Rehbein, Jochen 224

Reintaller, Anton 107

Rembrandt, Harmenszoon van Rijn 126

Richard II, King of England $\quad 61,62$

Richardson, John E. 115

Riefenstahl, Leni 114

Rorty, Richard $\quad 78$

Roselli brothers 24

Rosengren, Inger 224

Rothkegel, Annely 224

Rumsfeld, Donald 37

Saki (Munro H.H.) 282

Schulze-Gaevernitz, G. von 21

Schweiger, Till 185

Seehofer, Horst $\quad$ 133n12

Selim III, Sultan of the Turks 149

Sellner, Martin 81

Seyß-Inquart, Arthur 107

Shakespeare, William $\quad 51,52,60,62,63,64$, $170 n 41$

Šima, Karel XII, 7, 75-92

Sinasi, Ibrahim 150

Skendorovic, Damir 101

Spengler, Oswald 132

Staling, Joseph $\quad 42$

Starkey, David 26

Steinberg 147 
Stepinac, Alojzije $\quad$ 168n34

Strache, Heinz-Christian $\quad$ 108, 109, 110, 111, $112,113,114$

Strobl, Natascha 79

Strossmayer, Josip Juraj 167n32

Suleiman, the Magnificent $166,169 n 40$

Süleyman I, Sultan of the Turks 152

Swift, Jonathan $\mathrm{X}$

Szekfü, Gyula $\quad$ 19, 20

Tacitus, Cornelius $\quad 131$

Tannen, Deborah 113

Tarrach, Jürgen $\quad 188$

Taylor, Charles 84

Teitelbaum, Benjamin $\quad 82,87$

Thanou, Vassiliki 143

Timur 129

Tisa, István 25

Tito, Josip Broz $\quad 8,168$

Tolstoy, Leo 126

Torquemada, Juan de 126

Trump, Donald 16on

Tsvetkov, Yanko 252n13

Tuđman, Franjo $\quad$ 168, 169

Tutu, Desmond $\quad 208$

Uitz, Renate 117

Vaessens, Richard $\quad 252$

Valdeón, Roberto 211

Valle-Inclán, Ramón del $\quad 254,264$

Vesta 135,136

Vilimsky, Harald 114

Virchow, Fabian $76 \mathrm{n}_{3}, 80$

Vitezović, Pavao Ritter $\quad$ 167n29
Vladislaus I, King of Hungary and Croatie $165 \mathrm{n} 23$

Vladislaus II, King of Bohemia and Hungary $165^{\mathrm{n}} 23$

Voltaire 131

Von der Lage-Müller, Kathrin $\quad$ 224, 225

Vreese, Claes de 111

Vytautas, Grand Duke of Lithuania 41

Wardle, Irving 275

Waugh, Evelyn $\quad 276$

Weber, Max 131

Weinhart, Martin 187

Wellgraf, Stefan 193

Wellington, Arthur Wellesley, Duke of 67

Wever, Bart de 25

Wilde, Oscar 276

Wilhelm II, German Emperor 20

William, of Orange $\quad 25$ O, 252, 253

William III, King of England 56, 57

Willinger, Markus 81

Winkler, Heinrich August $\quad 26$

Wodak, Ruth XII, 3, 5, 7, 95-119, 223

Wodehouse, P.G. $\quad 276$

Yanukovich, Viktor 40, 43

Yeats, W.B. $\quad 275,276$

Yiannaras, Hristos 147

Young, Hugo 6o, 66

Yushchenko, Viktor 40

Zajc, Ivan 170

Zambelios, Spiridon $\quad 146$

Ziya Pasha 150

Zrinski, Nikola Šubić $\quad$ 166, 169, 170 